\title{
THE ECOLOGY OF TIJUANA ESTUARY
}

\section{A NATIONAL ESTUARINE RESEARCH RESERVE}
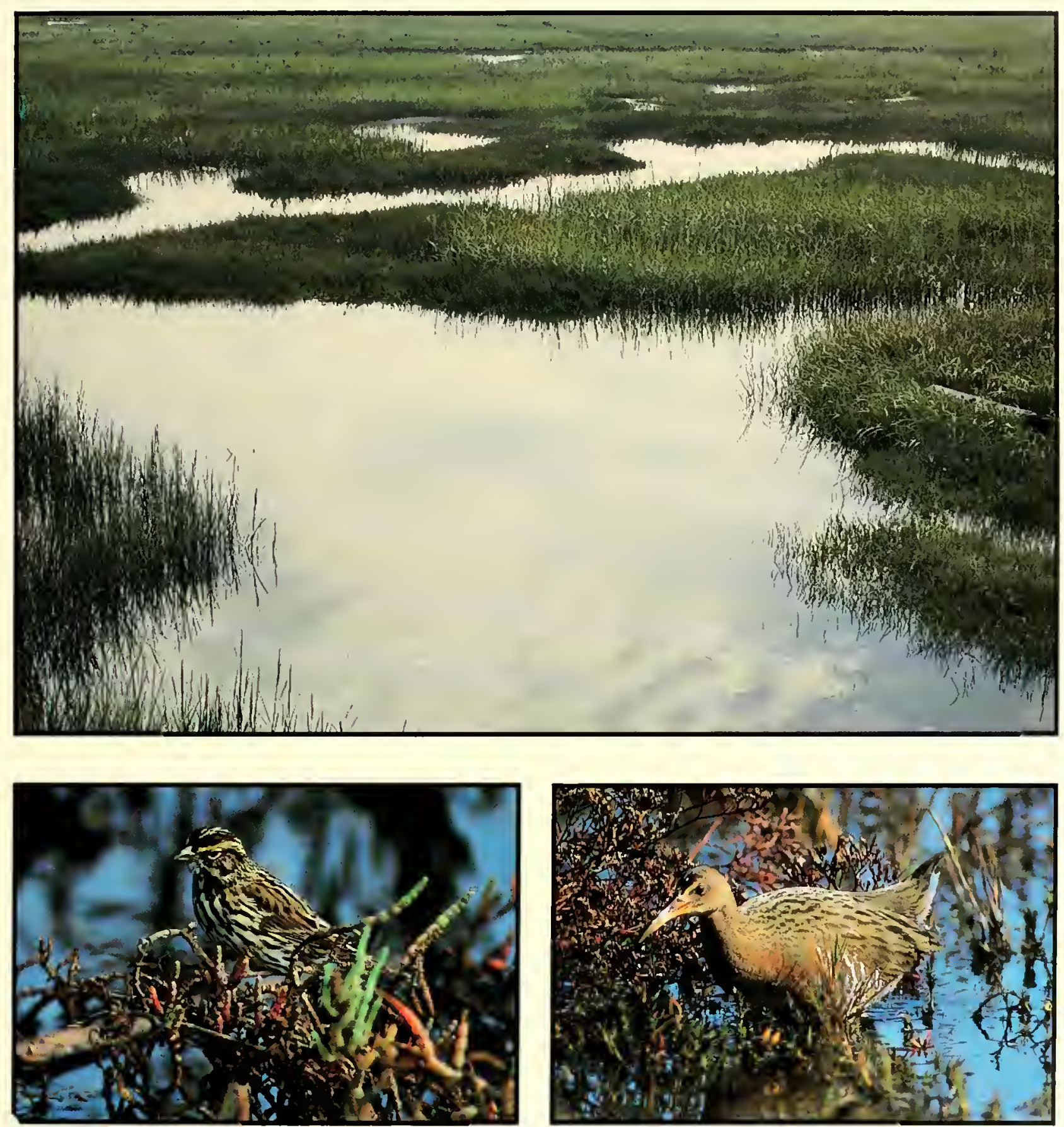

by Joy B. Zedler, Christopher S. Nordby, and Barbara E. Kus Pacific Estuarine Research Laboratory, San Diego State University 


\title{
Artwork
}

Drawings of wetland plants and animals by Donovan Mclntire

\section{Color photo credits:}

\author{
Cover: \\ salt marsh view by Pat Flanagan \\ light-footed clapper rail (c) 1992 by Juliette Murguia \\ Belding's Savannah sparrow (c) 1992 by Juliette Murguia \\ Inside color pages: \\ salt marsh bird's beak (a hemiparasitic plant) (c) by Phillip Roullard \\ dodder (a parasitic plant) by Pat Flanagan \\ egret and salt marsh (c) 1992 by Juliette Murguia \\ shorebirds (willets, godwits, short-billed dowitchers) (C) by Phil Roullard \\ least Bell's vireo (c) by Phillip Roullard \\ avocet (c) by Phillip Roullard
}

This report should be cited as:

Zedler, J. B., C. S. Nordby, and B. E. Kus. 1992. The Ecology of Tijuana Estuary, California: A National Estuarine Research Reserve. NOAA Office of Coastal Resource Management, Sanctuaries and Reserves Division, Washington, D.C. 


\title{
THE ECOLOGY OF TIJUANA ESTUARY, CALIFORNIA
}

\section{A National Estuarine Research Reserve}

\author{
by \\ Joy B. Zedler \\ Christopher S. Nordby \\ and \\ Barbara E. Kus \\ Pacific Estuarine Research Laboratory \\ Biology Department \\ San Diego State University \\ San Diego, CA 92182
}

1992

\begin{tabular}{c} 
MARINE \\
BIOLCGICAL \\
LABORATORY \\
\hline LIBRARY \\
\hline WOOES HOLE, WAOS. \\
W. H. O. I.
\end{tabular}

This is a revision of the 1986 Estuarine Profile (Biological Report 85(7.5)) by Joy $\mathrm{B}$. Zedler and Christopher S. Nordby, which was performed for the National Coastal Ecosystems Team, U.S. Fish and Wildlife Service, Washington, DC, and the California Sea Grant College, La Jolla, CA

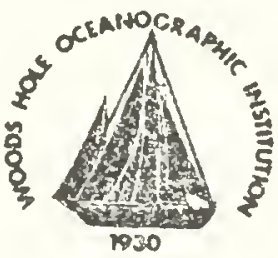





\section{CONTENTS}

PREFACE

ACKNOWLEDGMENTS

CH. 1 INTRODUCTION TO THE TIJUANA RIVER

NATIONAL ESTUARINE RESEARCH RESERVE ...............

1.1 The International Setting ........................

1.2 Estuary Type Characterization ...................... 1

1.3 The Estuarine Habitats . . . . . . . . . . . . . . . . . . . . 3

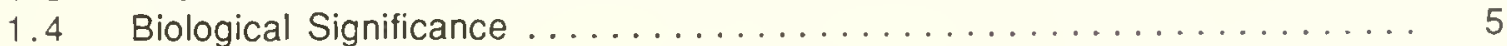

1.5 Protection Efforts .............................. 5

1.6 National Recognition ................................ 5

1.7 The National Estuarine Research Reserve (NERR) . . . . . . . . . . . . 6

1.8 The Research . . . . . . . . . . . . . . . . . . . . . . . . 7

1.9 Management ............................... 7

CH. 2 ENVIRONMENTAL CONDITIONS THAT SHAPED THE ESTUARY ..... 9

2.1 Geologic History . . . . . . . . . . . . . . . . . . . . . . 9

2.2 Mediterranean-type Climate ........................ 12

2.3 Land Use History. . . . . . . . . . . . . . . . . . . . . . . . 15

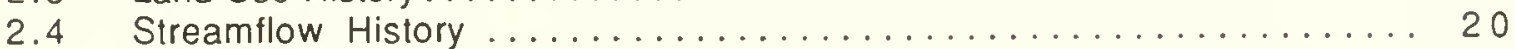

2.4.1 Major Flood Events ....................... 20

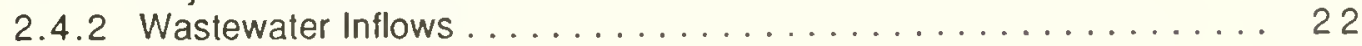

2.4 .3 Tidal Prism ......................... 22

CH. 3 ECOLOGICAL COMMUNITIES AT TIJUANA ESTUARY ......... 25

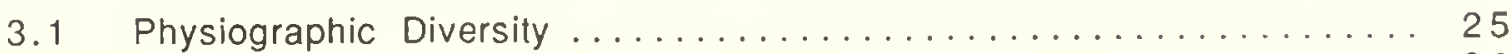

3.2 Transition from Upland to Wetland ..................... 26

3.2.1 Plants of the Wetland-Upland Transition .............. 26

3.2.2 Animals of the Wetland-Upland Transition .............. 28

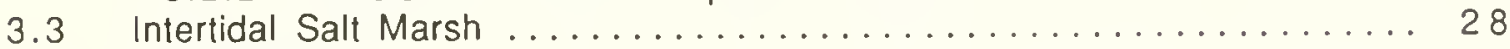

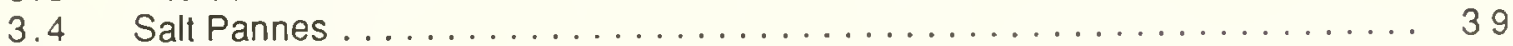

3.5 Brackish Marsh ............................... 41

3.6 Estuarine Channels and Tidal Creeks ..................... 45

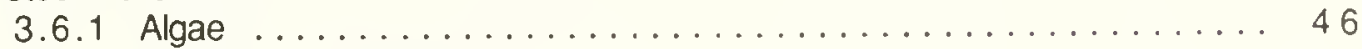

3.6 .2 Benthic Invertebrates ......................... 47

3.6.3 Fishes--Adults and Juveniles .................. 53

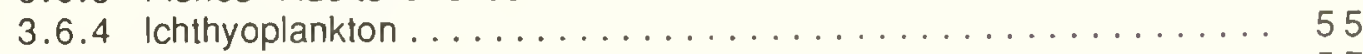

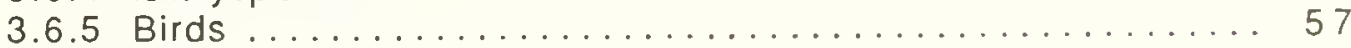

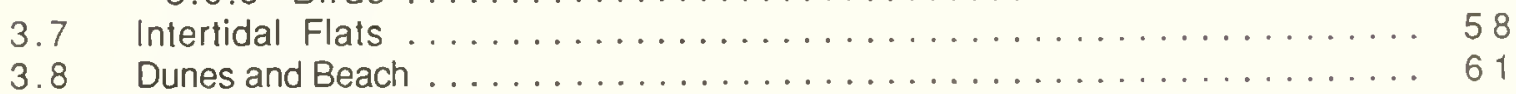

3.9 Riparian Habitats . . . . . . . . . . . . . . . . . . . 65

3.10 Dynamics of Featured Species ........................ 66

3.10.1 Spatial and Temporal Patterns of Habitat Use by Waterbirds . . . . 66

3.10 .2 Species of Special Concern . . . . . . . . . . . . . . . . 72 
CH. 4 ECOSYSTEM FUNCTIONING

4.1 Primary Productivity of Channel Algae . . . . . . . . . . . . . . 79

4.2 Productivity of Epibenthic Algal Mats . . . . . . . . . . . . . . . 82

4.3 Vascular Plant Productivity and Biomass .................. 85

4.4 Nutrient Interactions ........................... 88

4.4.1 Nitrogen Fluxes in 1977-1978 ................ 89

4.4.2 Nitrogen Additions to Salt Marsh Vegetation ............. 90

4.5 Energy Flow .................................. 92

4.5 .1 Detrital Production ........................ 92

4.5 .2 Feeding and Growth Rates ..................... 93

4.5 .3 Carbon Fluxes ......................... 94

4.5 .4 Temporal Variability in Filtering Functions ............ 95

CH. 5 THE ROLE OF DISTURBANCES IN MODIFYING

SALT MARSH STRUCTURE AND FUNCTION .............. 99

5.1 Monitoring Program ......................... 99

5.2 Physical Changes Following Ecosystem-wide Disturbances ........... 100

5.2 .1 Soil Salinity Changes ..................... 100

5.2 .2 Sedimentation in the Salt Marsh ................... 101

5.3 Effects of Major Disturbances on Salt Marsh Composition ............ 102

5.3 .1 Dynamics of the Cordgrass Marsh ................. 102

5.3.2 Responses of the Mid-Elevation Marsh to Nontidal Drought . . . . . 104

5.3 .3 Mid-Elevation Dynamics After $1984 \ldots \ldots \ldots \ldots \ldots 107$

5.3.4 A Conceptual Model of Compositional Change ............... 108

5.4 Effects of Major Dislurbances on Cordgrass Growth . . . . . . . . . . . . . 109

5.4.1 Freshwater Addition in a Field Experiment .............. 111

5.4 .2 Manipulation of Inundation in Outdoor Mesocosms ........... 112

5.4.3 Manipulation of a Competitor in Field Experiment ........... 113

5.4 .4 Nutrient Addition Experiments ................... 114

5.4 .5 Conclusions from Experiments ................. 114

5.5 The Revised Monitoring Program ....................... 114

5.6 Results of the New Adaptive Monitoring Program, 1989-1991 ... . . . 117

5.6 .1 Soil Salinities ........................... 117

5.6 .2 Salt Marsh Vegetation ... . . . . . . . . . . . . . . . . 117

5.7 Tijuana Estuary as a Reference Site for "Naturally Functioning" Salt Marsh. 118

5.8 Responses of Fishes and Benthos to Hydrologic Disturbances . . . . . . . . . 119

5.8.1 Sampling to Document Changes in the Channel Community ....... 120

5.8 .2 Responses of the Fish Community ................ 120

5.8 .3 Benthic Invertebrate Responses ................ 121

5.8 .4 Cause-Effect Relationships .................... 121

5.8 .5 Summary .......................... 122 
6.1 Research Needs and Opportunities . . . . . . . . . . . . . . . . 123

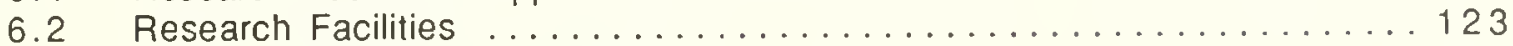

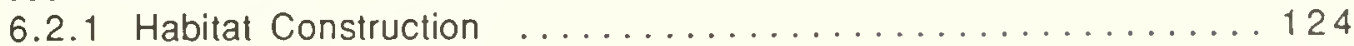

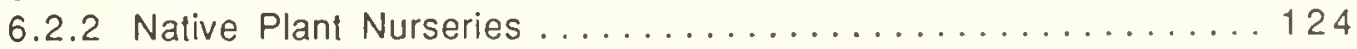

6.2.3 Wastewater Wetland Mesocosms .................. 125

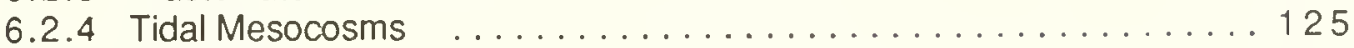

6.3 Management Needs ............................ 126

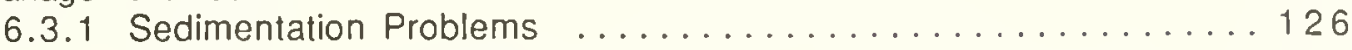

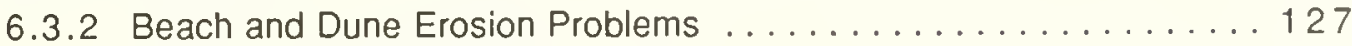

6.3 .3 Streamflow Modifications .................... 127

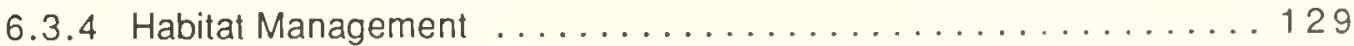

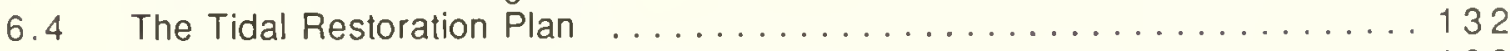

6.4 .1 The Restoration Planning Process ................ 132

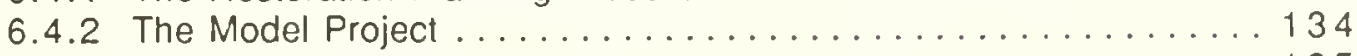

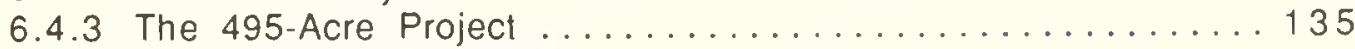

6.4 .4 Restoration Research Needs ................... 135

6.5 Mitigation Concerns ........................... 137

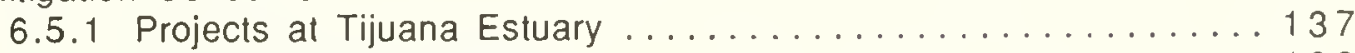

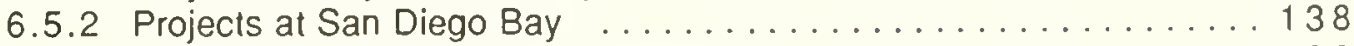

6.5 .3 Why Habitat Restoration is Difficult ................ 138 


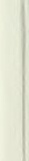




\section{PREFACE}

The Nation's estuaries are heterogeneous in size, physiography, watershed interactions, chemistry, and biota. In this Profile, we point out how the various properties of Tijuana Estuary compare to those of other estuaries within the region as well as within the nation. The designation of Tijuana Estuary as one of the National Oceanic and Atmospheric Administration's National Estuarine Research Reserves shows that it is one of a class of ecosystems worthy of research and education, yet different enough to warrant selection as a regional type.

What makes Tijuana Estuary eligible for national recognition? It functions as a coastal water body that is influenced by both marine and river waters. It supports a range of natural plant and animal communities that are especially adapted to withstand the variable salinities that occur when sea and fresh waters mix. It has persisted through human history as an ecosystem that retains many of its natural qualities despite disturbance from urban and agricultural land uses. Unique to Tijuana Estuary is its international setting, with three-fourths of its watershed in Mexico; its diversity of ecological communities, which provide habital for a variety of rare and endangered species; and its history of ecological study, with extensive data from years with and without catastrophic disturbances.

What sets California's estuaries apart from others in the nation is the degree of variability in the physical environment. During most of the year, they are marinedominated systems, i.e., extensions of the ocean. During the winter rainy season, they may become completely fresh. In addition, there is substantial annual variation from years with no streamflow to years with major floods. The extremely variable nature of southern California's coastal habitats is not evident from shortterm observation. Indeed, many visitors enjoy weeks of warm, cloud-free days and deny that we even have "weather." But from over a decade of study, there have been repeated opportunities to witness extreme events within Tijuana Estuary, ranging from catastrophic flooding to tidal closure and drought. These events have in turn allowed us to identify how physical factors influence biotic communities, and to quantify the dynamics of estuarine organisms as they respond to environmental extremes. 


\section{ACKNOWLEDGMENTS}

This book is a revision of Zedler and Nordby (1986). Printing was paid for by the National Oceanic and Atmospheric Administration (NOAA), Office of Coastal Zone Management, Sanctuaries and Reserves Division. The 1986 version was funded by the U.S. Fish and Wildlife Service (FWS) as one in their series of "estuarine profiles." FWS also supported an earlier "community profile" (Zedler 1982), which described our regional salt marshes.

Research funds for Tijuana Estuary have come from the California Sea Grant College and the California State Resources Agency for a variety of projects, beginning in 1976. Sea Grant-sponsored research has in turn led to additional projects that have had specific application to a variety of management agencies. The Sanctuaries and Reserves Division of NOAA has funded monitoring programs and supported graduate research on several reserve management issues. The U.S. Fish and Wildlife Service and the U.S. Navy both funded work on habitat characteristics for the endangered light-footed clapper rail. The California Water Resources Control Board, through funding from the Environmental Protection Agency's Water Quality Program, supported studies of the estuary's hydrological qualities and potential impacts of wastewater discharge.

Paul Jorgensen, Research Reserve Manager called our attention to many of the management problems at the estuary. We owe the greatest debt to students and colleagues, who have done so much of the field work and provided so many of the ideas that contribute to our understanding of Tijuana Estuary. In order of thesis completion date, we acknowledge the significant contributions of Ted Winfield, Phil Williams, John Boland, Chris Nordby, Jordan Covin, Pam Beare, Regina Rudnicki, Peggy Fong, Lisa Wood, Brian Fink, Abby White, Ted Griswold, Kendra Swift, John Cantilli, Sue Rutherford, Malgorzata Zalejko, George Vourlitis, Max Busnardo, and Theresa Sinicrope.

We thank Dra. Silvia Ibarra and sludents from CICESE in Ensenada, Baja California, for showing us less disturbed wellands in Baja California and providing comparative data on Mexican salt marshes. Several postdoctoral research associates, R. Koenigs, W. Magdych M. Kentula, B. Dubinsky, R. Langis, and J. Boland, and colleagues at San Diego State University, R. Gersberg, G. Cox, K. Williams, P. Zedler, B. Nyden, S. Williams, C. Cooper, J. Conway, D. Dexter, S. Hurlbert, P. Kern, P. Pryde, R. Wright, and D. Stowe, contributed their special expertise to the information reported here. Field work by J. Tiszler, E. Taylor, B. Espinoza, K. Johnson, S. Snover, N. Warnock, D. Parker-Chapman and $P$. Ashfield documented estuarine resources. The drawings by Donovan Mcintire made both technical and artistic contributions.

Without Donna Ross, this revision would still be a collage of unformatted text and figures. We also acknowledge with gratitude the reviewers of the 1986 version (W. Ferren, $P$. Jorgensen, $M$. Kentula, G. Kramer, S. Lockhart, C. Onuf, E. Pendleton, and the late M. Quammen). 


\section{CHAPTER 1}

\section{INTRODUCTION TO THE TIJUANA RIVER NATIONAL ESTUARINE RESEARCH RESERVE}

The story of Tijuana Estuary is complex. Ecologically, it has been influenced by its highly variable environment. Historically, it has shifted from a natural to a highly modified system. Politically, its fate has been holly debated, and competing interests continue to influence its management.

This is an attempt to synthesize and interpret a growing data base on the estuary's diverse biota -- its vegetation, algae, birds, fishes, and invertebrates. Because so many changes have occurred in response to catastrophic events, we describe how each aspect of the estuary appeared before 1980 and how it has responded 10 several perturbations. The experimental tests of these cause-effect relationships have not been completed, and there is little reason to expect that environmental conditions have stabilized or that new types of disturbances won't occur. Thus, this profile should be viewed as a stage in the process of understanding Tijuana Estuary. Like the estuary itself, our knowledge is continuously evolving.

\subsection{THE INTERNATIONAL SETTING}

Tijuana Esluary is entirely within San Diego County, California, although threefourths of its watershed is in Mexico (Figure 1.1). The Tijuana River originates in the mountains of Baja California. Water from the United States portion of its watershed flows down Cottonwood Creek and joins the Tijuana River in Mexico. The river then crosses the border just north of the city of Tijuana, Baja California.
On old maps, Tijuana Estuary is called Oneonta Lagoon or Slough. The Tijuana River, which feeds it, has been variously called Rio Tecate, Rio Tijuana, Tia Juana River, and Tijuana River. In 1968, the U.S. Board on Geographic Names approved the name Tijuana River (D. Orth, Executive Secretary, U.S. Board on Geographic Names, letter). Somewhat later, the name Tijuana began to replace Oneonta, but not everyone recognizes it as an "estuary." Yet, is does fit the most widely used definition, namely, "a semienclosed coastal body of water" that is "measurably diluted by fresh water..." (Pritchard 1967). Because of its location as the south-westernmost corner of the continental United States, it has both national and international significance.

As discussed throughout this profile, the estuary is very much a function of its watershed. The land uses and management practices on both sides of the border greatly influence the quantity and quality of water entering Tijuana Estuary. Thus, it is important to characterize the regional environmental conditions that have shaped and continue to shape this international estuary (Chapter 2 and Chapter 3, respectively).

\subsection{ESTUARY TYPE CHARACTERIZATION}

Pritchard (1967) developed an estuarine classification scheme based on geologic origin and physiography. In this frame of reference, Tijuana Esluary is very much like most of the world's estuaries, because it is a flooded river valley, also known as a coastal plain estuary. As sea level rose during the last posiglacial 


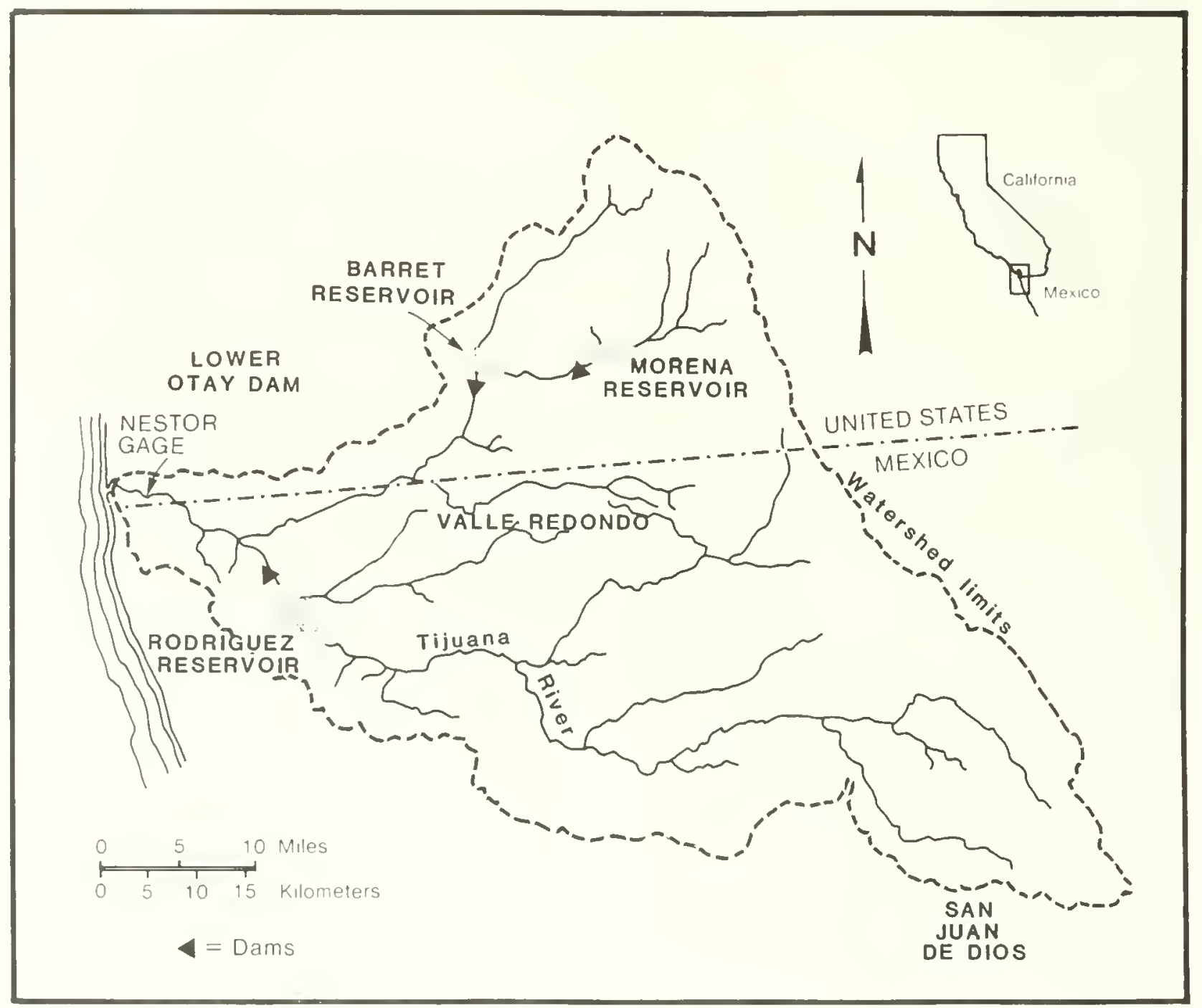

Figure 1.1. Location of Tijuana Estuary and map of watershed. Stations are indicated where rainfall and precipitation were measured (from IBWC 1983).

period, marine waters submerged the Tijuana River valley. Sediments that were brought downstream from the watershed spread out between the coastal mountains to create a small but well-defined coastal plain (Figure 1.2). The action of wind and waves gradually built up a sandbar and dune system parallel to the coast, and formed a semi-enclosed body of water. The area where marine waters are intermittently mixed with fresh water from Tijuana River is a small estuary immediately adjacent to the coast.
In other respects, Tijuana Estuary is very different from most of the world's estuaries. It does not fit well within the salinity characterization schemes that have been developed to describe estuarine embayments (Davis 1978). Estuaries can be divided into salt-wedge (river-dominated), parlially mixed (salinity gradient downstream), or vertically homogeneous (brackish water throughout) types. They can also be distinguished by their salinity profiles as either positive (fresh water floating over saline water) or negative (warm saline water floating over cool fresh water). As we 


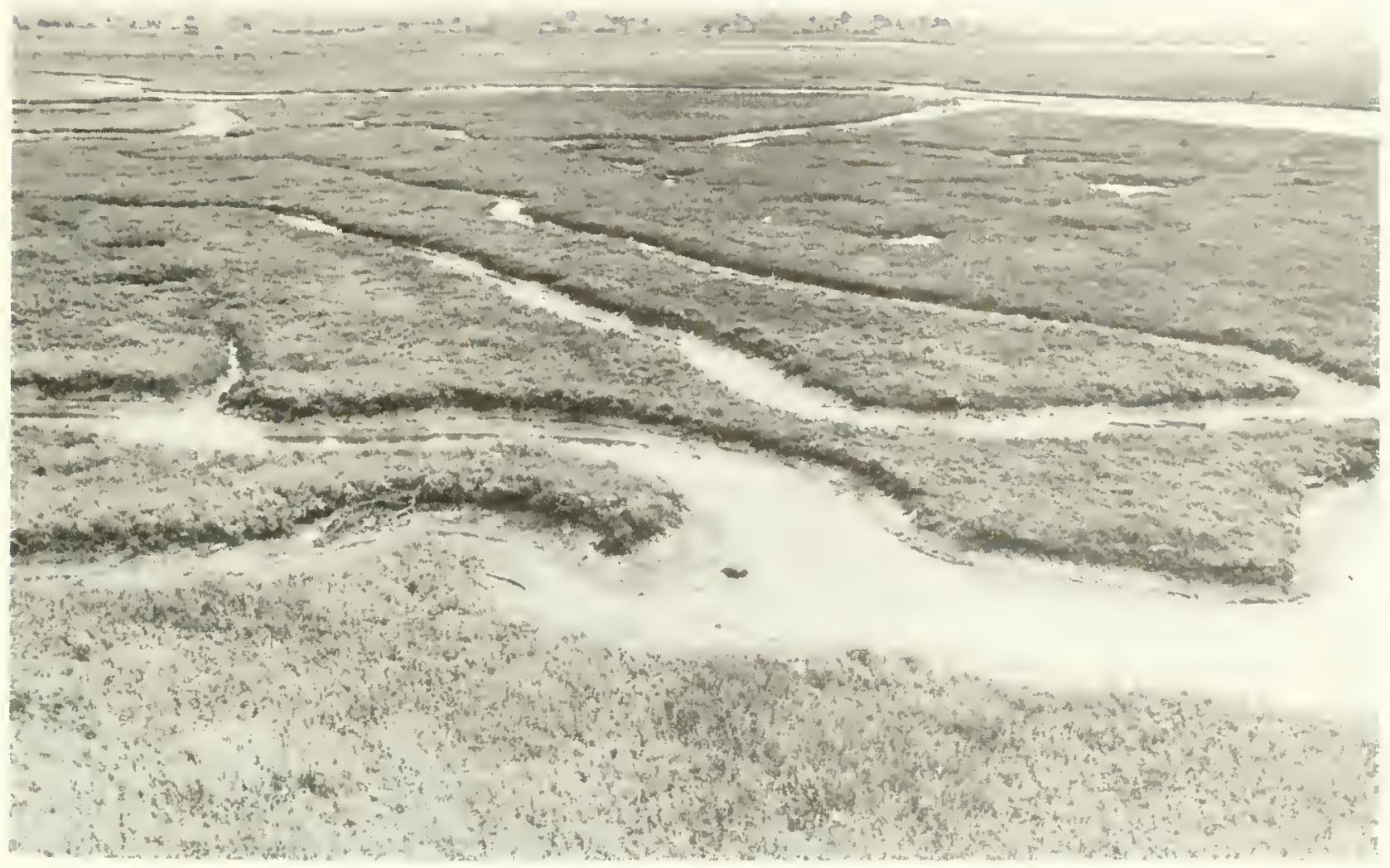

Figure 1.2. The northern arm of Tijuana Estuary, looking east (photo by D. Fink).

describe in Chapter 3, Tijuana Estuary is sometimes river dominated, sometimes partially mixed, and usually vertically homogeneous, although with marine rather than brackish water. Its vertical salinity profile can become positive or negative, depending on weather and tidal flushing conditions.

Because most of the estuary has shallowwater habitat, the wetland classification of Cowardin et al. (1979) is also applicable. The intertidal portion of the system fits within the California Province, estuarine system, intertidal subsystem, emergent welland class, persistent subclass, dominated by common pickleweed (Salicornia virginica) and Pacific cordgrass (Spartina foliosa).

Tijuana Estuary is a highly variable system that may best be termed an "intermittent estuary." During the winter wet season, its waters are diluted by rainfall and streamflow; during the rest of the year, it is an extension of the ocean. As sireamflow and wefland soil salinities suggest (Chapter 3 ), it may be one of the nation's most variable estuaries.

\subsection{THE ESTUARINE HABITATS}

Tijuana Estuary is a wetland-dominated estuary (Figures 1.2-1.3). There is no major embayment, but rather a series of channels and a relatively narrow ocean connection. In most years, the mouth has been open, and tidal flushing has prevailed. The intertidal area supports mostly salt marsh vegetation, while mudflats and sandflats occupy only a small fraction of the site. Inland, the upper salt marsh grades into transitional vegetation, which in turn grades into coastal scrub and chaparral. 


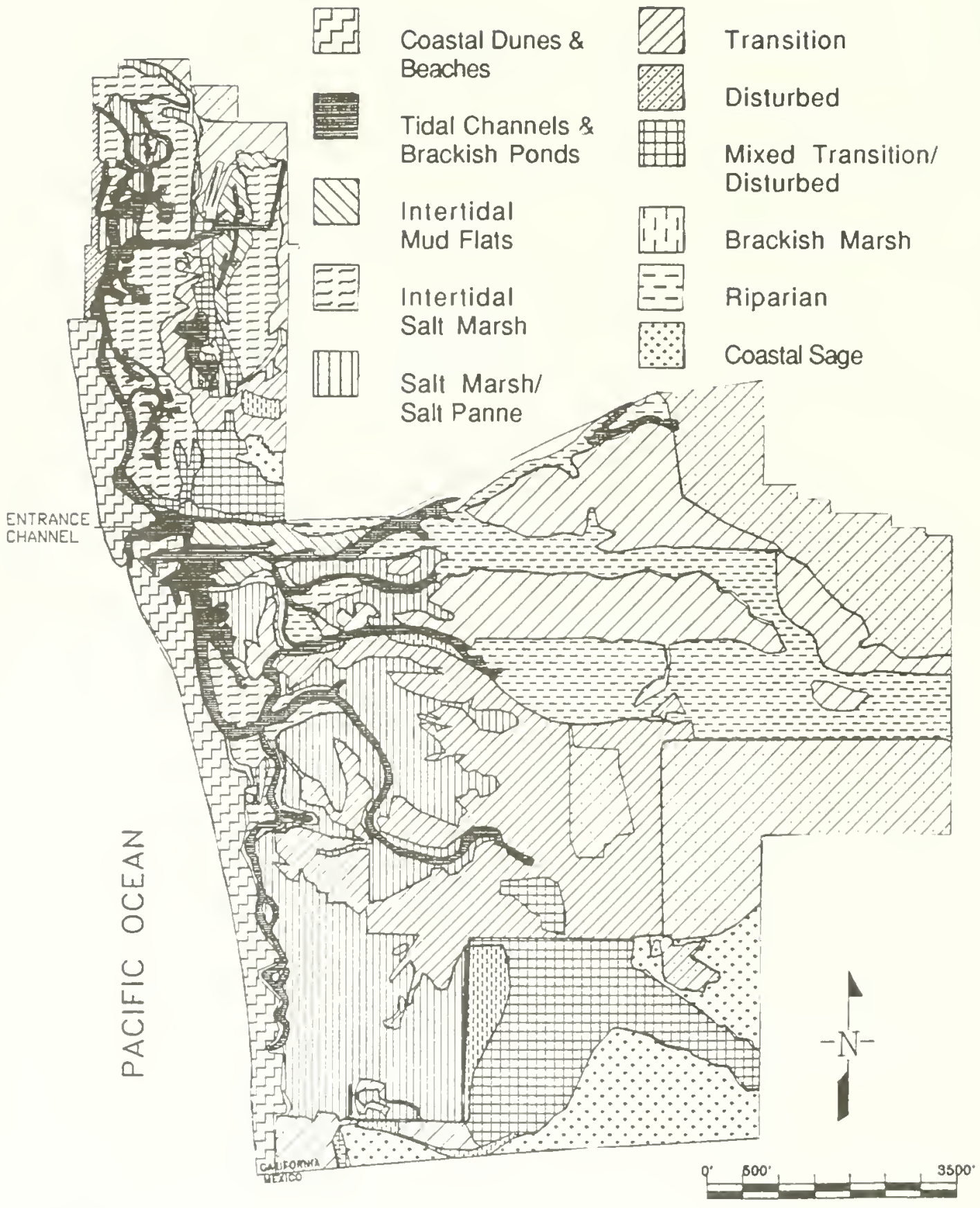

Figure 1.3. Map of habitat types at Tijuana Estuary (see Chapter 3 for descriptions and Table 3.1 for acreages of each). Habilats were delineated using the 1986 aerial photos, ground truthing, and topographic maps. This map was produced by a Geographic Information System, courtesy of the R. Wright, Geography Department, SDSU. Modified from Entrix et al. (1991). 
Many features of the estuary have been substantially altered by both natural and human disturbances. In the early 1900's, sewage disposal practices led to the dredging of an east-west channel to connect the estuary to an adjacent lagoon. Dikes were later constructed to subdivide that lagoon into three wastewater receiving ponds, which were subsequently abandoned and the dikes breached to improve tidal flushing. Gravel extraction for street and dike construction left isolated ponds within the estuary. Long-term dumping and filling altered most of the peripheral topography, and off-road vehicles denuded many roads and paths. Scars remain throughout the southern half of the estuary from former military, agricultural, and horse-raising activities. Present-day sewage spills from Mexico change the quantity, and certainly the quality, of inflowing waters. More recently, natural flooding in 1980 broadened the riverbed and changed its course. Winter storms in 1983 washed the dunes into the main channels and obliterated two salt marsh islands. The estuary closed to tidal flushing in April 1984 and remained nontidal until it was dredged open some eight months later.

Can any area that has experienced such extensive assaults still be considered a naturally functioning estuary? The closest we can come to answering that question is to compare it with more disturbed systems near Los Angeles and with less disturbed systems in Baja California. Tijuana Estuary ranks with the latter.

\subsection{BIOLOGICAL SIGNIFICANCE}

The presence of several rare and endangered species has focused the attention of resource agencies and environmentalists on Tijuana Estuary. Significant populations of the California least tern (Sterna antillarum browni) and the sall marsh bird's beak (Cordylanthus maritimus ssp. maritimus) remain at Tijuana Estuary. In addition, the State-listed Belding's Savannah sparrow (Passerculus sandwichensis beldingi) nests in the salt marsh. These and other rare and threatened species have declined in numbers as their habitats have succumbed to the pressures of development. Their persistence at Tijuana Estuary documents the importance of the area for wildlife. The plight of other species, such as the light-footed clapper rail (Rallus longirostris levipes), illustrates the need to enhance and maintain the area.

\subsection{PROTECTION EFFORTS}

Public ownership of lands was for many years the main protection against development. In 1971 the California Department of Parks and Recreation acquired U. S. Navy lands in the southwestern portion of the estuary (396 ac $=160$ ha) for Border Field State Park. The Navy retained a strip of land (263 ac = 106 ha) through the northern arm of the estuary, which is under its helicopter flight path.

In 1980 the U. S. Fish and Wildlife Service purchased a large part of the estuary (505 ac $=204 \mathrm{ha})$ from private owners for protection of endangered species and their habitat. This area became the Tijuana Slough National Wildlife Refuge.

\subsection{NATIONAL RECOGNITION}

Following an extensive selection and review process (OCZM and CCC 1981), Tijuana Estuary was designated a National Estuarine Sanctuary in 1982. It was later renamed a National Estuarine Research Reserve (NERR). Tijuana Estuary joined Padilla Bay in Washington, South Slough in Oregon, and Elkhorn Slough in central California to become the fourth Pacific Coast NERR. Tijuana Estuary was the nation's 10th NERR. Several attributes made this "southwesternmost estuary" eligible for national recognition. The site was relatively undisturbed for "a region characterized by degraded wetland and estuarine systems" (ibid., p. 44). It was known to support several protected bird species and to be a 
critical stopping place along the Pacific Flyway. It was one of only a few water bodies along the southern California coast that had escaped dissection by highways or railways.

The ecosystem was international in scope, with most of its watershed in Mexico and the estuary entirely within the U.S. Finally, it had proven its value as a research site. Tijuana Estuary's salt marshes were included in the earliest published work on the subject (Purer 1942). Numerous ecological studies were conducted prior to designation, including those on fishes (Ford el al. 1971), marsh vegetation (Zedler 1977), the endangered light-footed clapper rail (Jorgensen 1975), historic tide lines (Bradshaw and Phillips, unpubl. ms.), benthic invertebrates (Smith 1974; Peterson 1975; Hosmer 1977; Homziak 1977), the food value of detritus (Williams 1979, 1981), vascular plant productivity (Winfield 1980, Zedler et al. 1980), epibenthic algal mats (Zedler 1980, 1982a), and shorebird use (Boland 1981).

Important victories that preceded sanctuary status were won by Pat and Mike McCoy, who persuaded the Fish and Wildlife Service to purchase private lands for the Endangered Species Refuge. The McCoys also founded the Southwest Wetlands Interpretive Association to continue nature conservation work. A large number of activists convinced decision-makers not to dredge the estuary for a marina and not to replace Tijuana River with a concrete flood control channel.

National Estuarine Research Reserve status shaped the future of Tijuana Estuary. It designated the California Department of Parks and Recreation as the lead agency to implement the Reserve and made possible the development of a management plan (Dobbin Associates 1986). It established a Management Authority with broad representation, including resource agencies, the county, and two cities. A manager (Paul Jorgensen) and an education coordinator (Pat Flanagan) were employed. Several parcels of land were acquired for the Reserve, including land being held as a possible site for a power plant. Funding for a visitor center followed, and the Visitor Center at 301 Caspian Way, Imperial Beach, was completed in 1990.
Setting the estuary aside for research, education, and interpretation was a tremendous accomplishment. If was the culmination of more than a decade of efforts to protect the area from intensive development, but it was by no means the end of controversy. Nor did it solve a multitude of resource management problems. A few of the challenges that remain are sedimentation events that accompany catastrophic floods and reduce tidal influence; the continual movement of undocumented aliens that cross the international border and move through the estuary; the trampling of coastal vegetation, which exposes erodible dunes to wind and storm damage; occasional dune washovers when sea storms wash the sand into the estuary, where it clogs lidal channels; occasional spills of sewage down the border canyons and into the estuary; discharge of raw sewage from Tijuana, Mexico, which has changed the intermittent stream into a continuously flowing "blackwater river;" unremitted filling in the river valley, which has constricted the river and increased flood risks, and development along the periphery of the estuary and river valley.

Tijuana Estuary is not a pristine system, but it has high potential for restoration. Current plans are to eliminate wastewater inflows, restore tidal circulation to the southern half of the estuary by removing accumulated sediments, stabilize the dunes with native vegetation, improve control of people who use and pass through the estuary, and enhance populations of native species that have declined as the estuary's tidal lifesupport system has diminished. Chapter 6 provides more detail on where and how these improvements will be made.

\subsection{THE NATIONAL ESTUARINE RESEARCH RESERVE (NERR)}

The 2,531-acre (1,024 ha) NERR site (Figure 1.4) includes the 505-ac (204 ha) Endangered Species Refuge owned by the U.S. Fish and Wildlife Service (FWS), 551 ac (223 ha) of Navy Land that is administered by US FWS, the 418-ac (169 ha) Border 
Field State Park, lands purchased for the Reserve, for which the City of San Diego holds title, lands held by the County of San Diego, and small inholdings under private ownership. Immediately upstream of the estuary is the Tijuana River Valley, where the County of San Diego is acquiring land for a regional park and considering a variety of enhancement measures. On the Mexico side of the border, the Tijuana River is a concretelined flood control channel, which extends inland towards Rodriguez Dam. Most of the 1,731 square mile $(4,483 \mathrm{sq}$. $\mathrm{km}$.) watershed is behind this major dam.

\subsection{THE RESEARCH}

In the first year that research funding became available through the NERR program, four graduate students entered the national competition and obtained support for work on phytoplankton (Fong 1986), macroalgal dynamics (Rudnicki 1986), dune restoration (Fink 1987), and interactions of native and exotic dune plants (Wood 1987). Thereafter, the sludies supported through NERR concerned ecosystem monitoring (Zedler and Covin 1984, Covin 1984, Covin and Zedler 1988), the dynamics of marsh vegetation (Covin et al. 1986, Zedler et al. 1986 , Zedler 1986), soils (Mayer 1987). reestablishment of plant populations (Zedler and Covin 1987), the response of fish and benthic invertebrates to wastewater influxes (Nordby and Zedler 1988, Nordby and Zedler 1991), simulation modeling and salt marsh monitoring (Brenchley-Jackson et al. 1990), and wastewater wetlands to protect Tijuana Estuary from sewage pollution (Busnardo 1992, Sinicrope 1992).

The California Sea Grant Program, the State Resources Agency, the State Coastal Conservancy, and other agencies have funded research that complements and extends the knowledge base for Tijuana Estuary. Studies carried out at the NERR have had major impacts on landscape planning and resource management throughout California.
- Plans to restrict wastewater discharge to coastal streams have been guided by the detrimental effects of salinity reduction that have been documented at Tijuana Estuary.

- Management goals of providing full tidal flushing to tidally impaired systems have been based on the impacts of tidal closure, which occurred in the estuary in 1984.

- Methods of restoring functional salt marsh habitats have been based on experimental work at the NERR.

- Artificial wellands (72 ponds within a 30-acre NERR site) were shown effective in attracting wildlife and subsidizing habitat for the estuary's bird populations.

- Innovative research on how to manipulate the hydroperiods (filling and drainage regimes) of wetlands constructed for wastewater treatment has shown how effective marsh soils and plants are in removing nitrogen and heavy metals from wastewater. This project, along with the artificial wetland demonstration project, has influenced plans for reclaiming and reusing wastewater. It is likely that the future will see a major change in the way treated wastewaters are managed. Instead of discharging effluent to the ocean, it will be reused in irrigation, and excess volumes will probably be impounded for marsh habitat, wildlife production, ground-water recharge, and esthetic appreciation, with proper controls on outflow to avoid damage to saline habitats along the coast.

\subsection{MANAGEMENT}

Management of the Research Reserve is a cooperative effort that involves many agencies and individuals (Chapter 6) in accordance with the management plan (Dobbin Associates 1986). Only three other NERRs are located along the Pacific coast: Elkhorn Slough on Monterey Bay, California; South Slough on Coos Bay, Oregon; and Padilla Bay in Washington. 


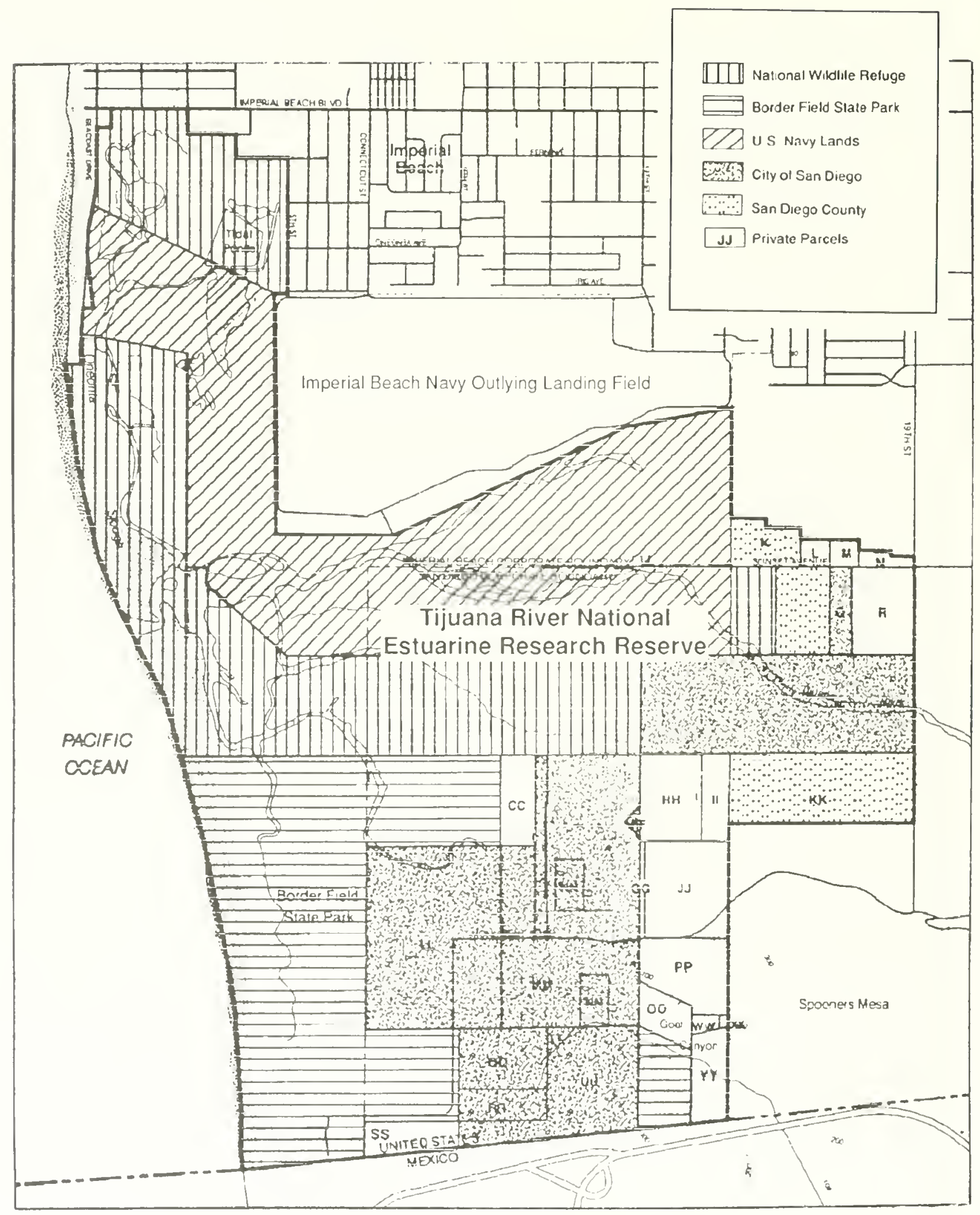

Figure 1.4. Land ownership at the Tijuana River National Estuarine Research Reserve. Modified from Dobbin Assoc. (1986). 


\section{CHAPTER 2}

\section{ENVIRONMENTAL CONDITIONS THAT HAVE SHAPED THE ESTUARY}

\subsection{GEOLOGIC.HISTORY}

The geologic history of Tijuana Estuary and its adjacent coast is poorly studied. Yet it is so different from most of the Nation's estuaries that even the most general descriptions are useful. In his review of sea level and coastal morphology during the late Pleistocene, Bloom (1983a,b) characterized the Pacific Coast as "a total contrast to the trailing continental margin with coastal plains of the Atlantic and Gulf coasts. Active tectonics associated with regional strike-slip faulting characterize the California coast."

As continental drift shifted North America toward the west, a steep coastline and narrow continental shelf developed (Figure 2.1). Marine terraces were gradually carved along the shores. Then, in the late Cenozoic, tectonic uplift raised alluvial terraces to several hundred meters above modern sea levels; the lowest of these terraces were laid down 125,000 to 80,000 years ago ( $\mathrm{Ku}$ and Kern 1974; Kern 1977; Lajoie et al. 1979). In some places, the youngest terraces have been thrust $40 \mathrm{~m}$ above current shorelines.

Because the shelf has a steep decline, Pleislocene glaciation and receding sea levels did not expose large expanses of coastal land. What is now the Tijuana River presumably cut through these terraces, although the narrow floodplain suggests that flows were not consistently large. The cut that frames Tijuana Estuary is only a few kilometers wide.

The picture emerges of a sharp, steeply inclined coast with vertically active terraces. Then, in the Holocene, a rising sea began to reclaim the exposed margins of the coastal shelf. As Bloom (1983a) goes on to say, "the last 15,000 years of California coastal evolution have been dominated by submergence coincident with deglaciation." The rivers were drowned and lagoons formed as longshore drift crealed sandy barriers along the coast. With flooding, most of the coastal embayments filled with sediment, and, without continuous river flow and scouring, their mouths closed between flood seasons.

The recent geologic faclors that have shaped the estuary are thus the competing forces of rising sea level, which promotes inland migration of the estuary, and tectoric uplift, which reverses that trend. The location of the shore and the configuration of the mouth are additional variables that influence the size and condition of the estuary. Longshore drift is generally southward in southern California, with flows interrupted by submarine canyons. However, the precise patterns and seasonal shifts at Tijuana Estuary have not been quantified. What is clear is that catastrophic beach erosion has shifted the shoreline landward in the past few years. How much of that shift is due to recent storms and how much is a general trend due to rising sea level are yet to be determined. Additional discussion of the magnitude of these changes and the impacts on estuarine habitats can be found in Chapter 5 .

The recent history of sea level rise has been summarized by Flick and Cayan (1984) and Cayan and Flick (1985). Data from 1906 to the present, taken in San Diego Bay, indicate an average rise of about 20 $\mathrm{cm} /$ century (Figure 2.2). During recurrent 


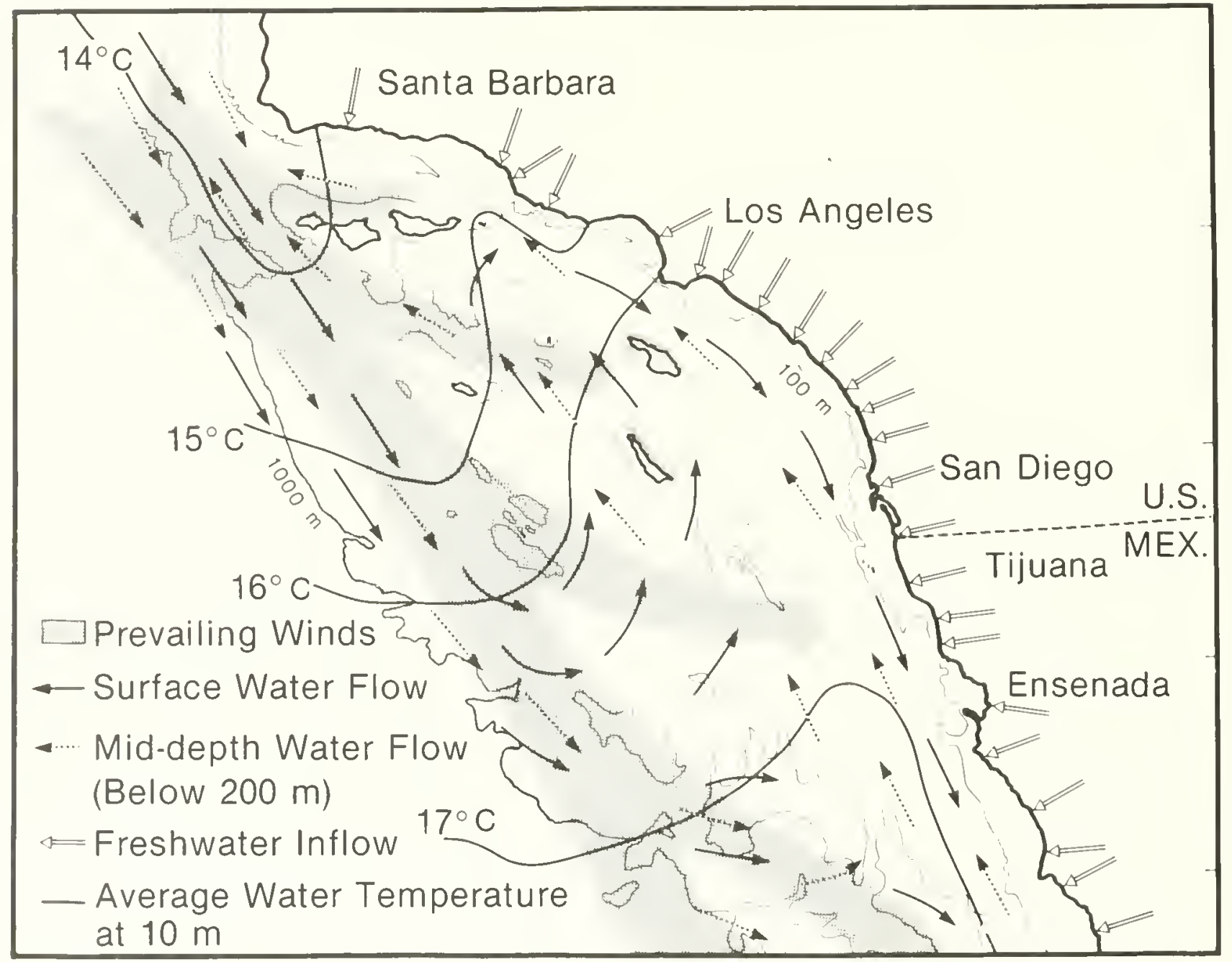

Figure 2.1. Nearshore patterns of bathymetry, wind, and ocean circulation (redrawn from Resources Partnership 1979).

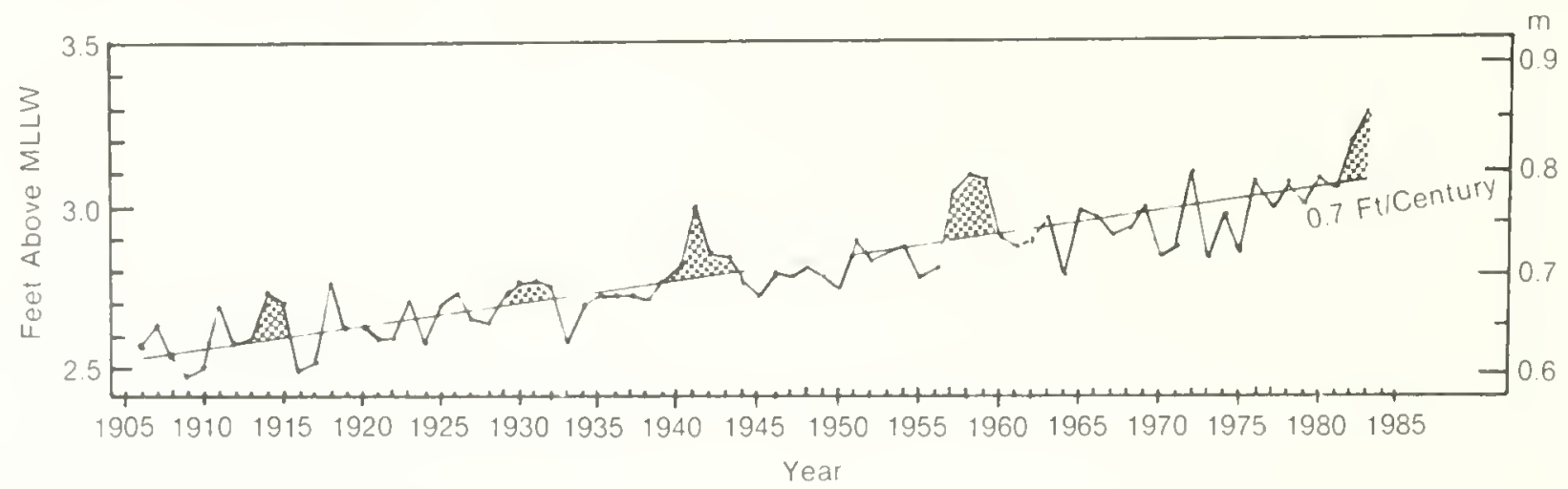

Figure 2.2. Data on sea level rise for San Diego Bay, $10 \mathrm{~km}$ north of Tijuana Esluary. Yearly mean sea level is referred to the 1960-78 datum for mean lower low water (MLLW). The linear increase is $21 \mathrm{~cm}(0.7 \mathrm{ft})$ per century. Shaded areas indicate periods of El Niño episodes (reprinted with permission from Cayan and Flick 1985). 
El Niño events, the rate of sea level rise has been even higher. The highest sea level on record occurred in January 1983, when predicted sea levels were exceeded by $26 \mathrm{~cm}$ due to the coincidence of El Nifio, high spring tides, and a major sea storm. Still, the water levels might have been even higher if these three events had also coincided with the highest point in the 19-year tidal cycle (Cayan and Flick 1985). The future location and configuration of the shoreline will depend on both the chronic and catastrophic increases in sea level. While the former will shift estuarine habitats inland, the latter will lap away at the marine margins.

The 1904 map of Tijuana Estuary (Figure 2.3) provides the earliest indication of historic conditions. Three features that are clearly mapped are not evident in later photographs. First, there is an isolated, landlocked lagoon in the northeastern part of the estuary. Without a natural connection between the lagoon and the rest of the estuary, this habitat must have been a highly variable wetland that filled in the rainy season and dried out in summer. Second, the mouth of the Tijuana River is represented as a minor bay, rather than a narrow channel. If this map does not represent an unusually high tide, then there was a much larger subtidal area than exists at present, and major sedimentation occurred after 1904. Third, there are two river courses, one entering the center of the estuary and one toward the southern end. The latter no longer connects with the river.

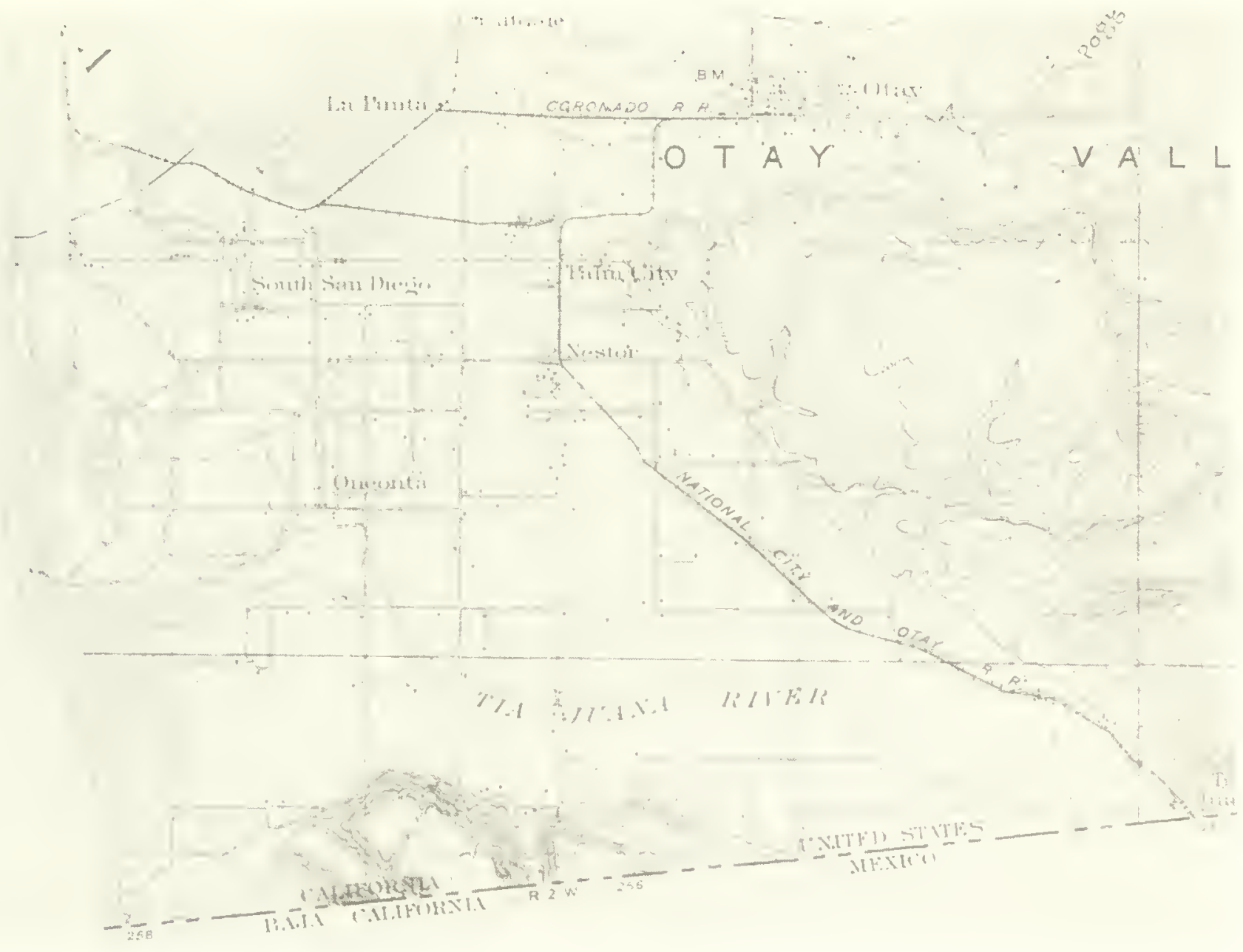

Figure 2.3. The 1904 map of Tijuana Estuary (from U.S. Coast and Geodetic Survey). 


\subsection{MEDITERRANEAN-TYPE CLIMATE}

Cool, wet winters and warm, dry summers characterize the climate of southern California. Most days are sunny, although morning fog is common along the coast. Solar radiation data for Chula Vista (the station nearest Tijuana Estuary) were collected in 1976 and 1977; the average was 411 calories $/ \mathrm{cm}^{2} /$ day, ranging from an average of 561 for June to 217 for December (Taylor 1978). Griner and Pryde (1976) state that San Diegans enjoy about $73 \%$ of the maximum possible sunshine. Daily temperatures average $17^{\circ} \mathrm{C} .\left(63^{\circ} \mathrm{F}\right)$, with monthly highs in July or August $\left(26^{\circ} \mathrm{C}, 78^{\circ} \mathrm{F}\right)$ and lows in January $\left(7^{\circ} \mathrm{C}, 45^{\circ} \mathrm{F}\right)$. Frost is rare along the coast.

The coastal climate of southern California is reminiscent of the Mediterranean region (Barbour and Major 1977), and the coastal vegetation is similar to that of France, southern Africa, and southwestern Australia, all of which have Mediterranean-lype climates. For coastal wetland vegetation, average rainfall on the coast is unlikely to be the direct determining factor; rather, the timing and amounts of rainfall and river flows within the entire watershed set limits on species distribution and growth. For intertidal organisms, conditions that cause high evaporation rates are also limiting. Hot, dry desert winds can be devastating, especially when they coincide with low tide. It is a climate with many extremes; some years and decades have little rainfall and runoff; other years have winter storms that cause tremendous floods. However, precipitation data indicate that storms are always of brief duration.

Data for six stations within the Tijuana Esluary watershed (Figure 2.4, Table 2.1) show the seasonal patterns of rainfall and evaporation. At all stations, evaporation exceeds precipitation in nearly every month. The more inland stations have lower ratios of evaporation and precipitation, as is typical of the western sides of mountain ranges (Table 2.1). Annual rainfall averages are about 25
Table 2.1. Locations of weather stations within the Tijuana River watershed (see Figure 2.4).

\begin{tabular}{ll} 
Station Lat. Long. $\begin{array}{r}\text { Elev. } \\
(\mathrm{m}) .\end{array}$ \\
\hline
\end{tabular}

UNITED STATES

$\begin{array}{llll}\text { Morena Dam } & 32^{\circ} 41^{\prime}, 116^{\circ} 31^{\prime} & 938 \\ \text { Barrett Dam } & 32^{\circ} 41^{\prime} & 116^{\circ} 40^{\prime} & 495 \\ \text { Lower Otay Dam } & 32^{\circ} 37^{\prime} & 116^{\circ} 56^{\prime} & 156\end{array}$

MEXICO

San Juan de Dios $32^{\circ} 59^{\prime} 116^{\circ} 00^{\prime}$

1280

Valle Redondo $\quad 32^{\circ} 3^{\prime} \quad 116^{\circ} 45^{\prime} \quad 242$

$\mathrm{cm}$ (10 inches), most of which falls between November and April. Although some winter months have heavy rainfall, monthly averages are less than $5 \mathrm{~cm}$ ( 2 inches). Annual evaporation rates are very high. Averages at Chula Visla for 1919-1981 (IBWC 1981) are $161 \mathrm{~cm}$ (64 inches) per year, with the maximum occurring in July $(19 \mathrm{~cm}=7.6$ inches per month). Even in winter, substantial water losses can occur. The minimum monthly average evaporation is for December, with $7 \mathrm{~cm}$ (2.8 inches).

Although rainfall patterns influence the intertidal portions of the estuary, temperature and salinity data for channel waters show that the subtidal habitats are much less variable (Table 2.2). When Tijuana Estuary is open to tidal flushing, monthly water temperalures vary only slightly, and water salinities change primarily with major river flows.

The rainfall data for San Diego extend back to 1880 and indicate that periods of relative drought were interrupted by wet years in $1883,1921,1940,1951,1978,1980$, 

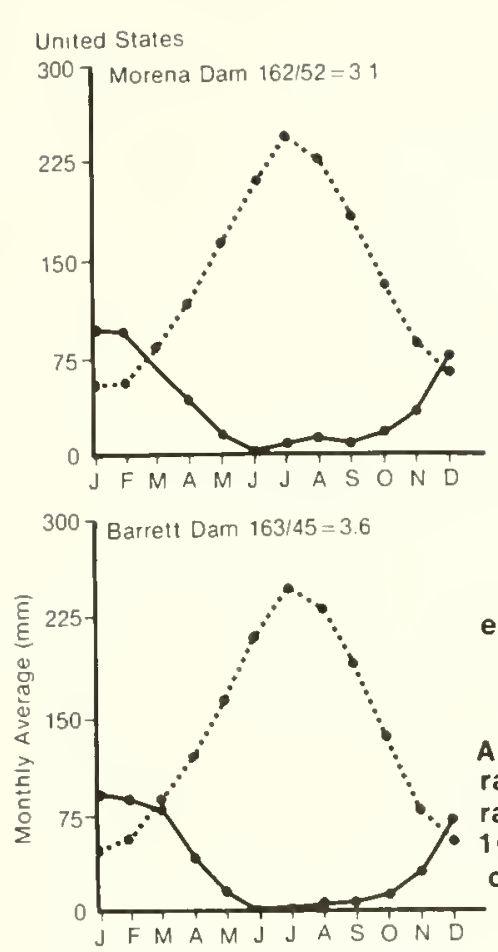

evaporation

rainfall

Annual evaporation and rainfall data and their ratio are given as, e.g., $162 \mathrm{~cm}$ evaporation $/ 52$ $\mathrm{cm}$ rainfall $=3.1$

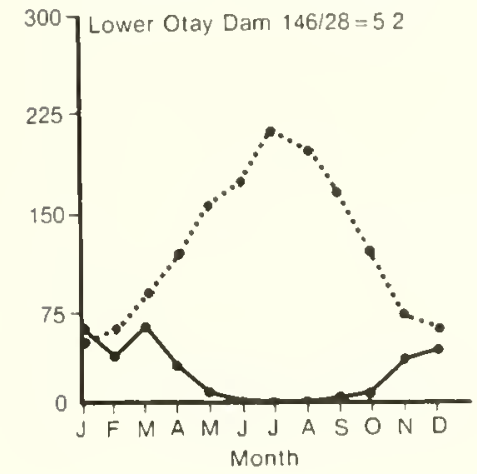

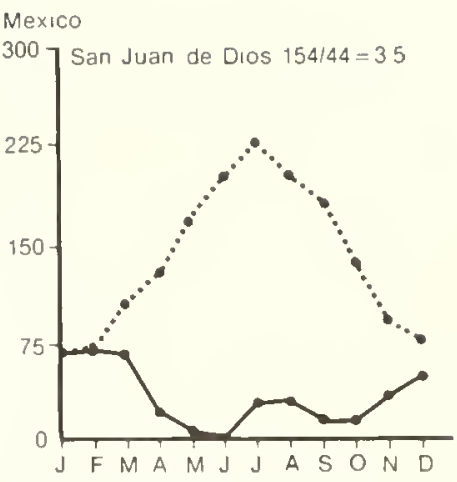
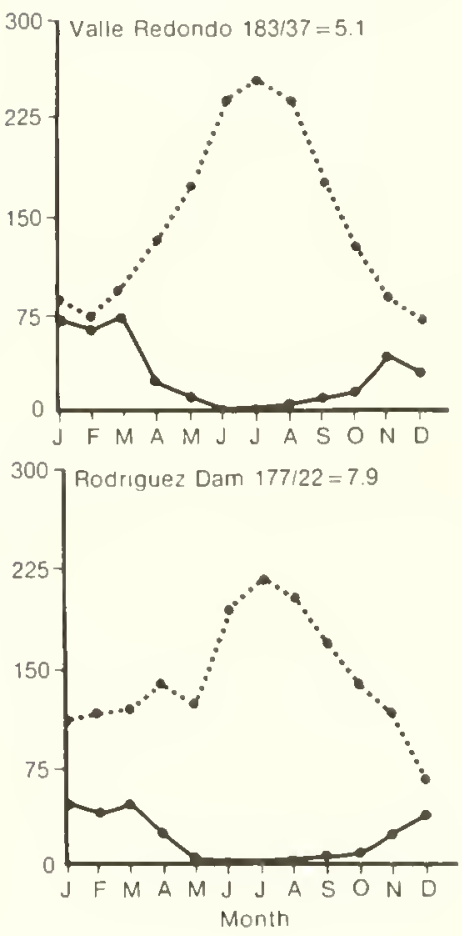

Figure 2.4. Monthly averages of evaporation and rainfall af six Tijuana River watershed locations in the U.S. and Mexico (see map, Figure 1.1, and elevations, Table 2.1; data from IBWC 1983).

and 1983. Rainfall patterns differed greatly for each of those years. In some years, there were summer storms $(5 \mathrm{~cm}$ of rain fell at Chula Vista in August 1977); in some years there were winter droughts (almosi no rain fell from late December 1983 through summer of 1984). Again, the factors most important to the estuary are not necessarily annual rainfall totals. Rather, from recent studies of estuarine dynamics, the amounts and limes of rainfall and streamflow within the entire Tijuana River watershed appear to be critical. The extremes of wet and dry years are apparent in the frequency hislogram for rainfall years (Figure 2.5) and in the high coefficient of variation $(438 \%)$. 
Table 2.2. Mean temperalure $\left({ }^{\circ} \mathrm{C}\right)$ and electrical conductivity $(\mathrm{mmho} / \mathrm{cm})$ at Winfield's (1980) tidal creek sampling stations in Tijuana Estuary. Conductivity is a measure of salinity; sea water is approx. 50 $\mathrm{mmhos} / \mathrm{cm})$. Data from two stations are averaged.

\begin{tabular}{lcccc}
\hline & \multicolumn{2}{c}{ Temperature } & \multicolumn{2}{c}{ Conductivity } \\
Date & Flood Ebb & \multicolumn{2}{c}{ Flood } & Ebb \\
& & & & \\
\hline $5 / 31 / 77$ & 19 & 18 & 50 & 51 \\
$6 / 29 / 77$ & 19 & 16 & 51 & 40 \\
$7 / 26 / 77$ & 20 & 19 & 46 & 47 \\
$8 / 26 / 77$ & 22 & 20 & 46 & 45 \\
$9 / 13 / 77$ & 21 & 25 & 46 & 46 \\
$10 / 25 / 77$ & 17 & 23 & 53 & 56 \\
$11 / 13 / 77$ & 20 & 20 & 54 & 54 \\
$1 / 10 / 78$ & 16 & 17 & 38 & 38 \\
$3 / 7 / 78$ & 14 & 18 & no data \\
$4 / 5 / 78$ & 18 & 20 & 57 & 63 \\
\hline
\end{tabular}

Rainfall data for San Diego's Lindbergh Field were recently re-examined to evaluate the concept of "normal rainfall.". The issue arose when the Environmental Protection Agency proposed new criteria for wetland delineation, which required that measurements of hydrology be conducted during "years of normal rainfall and normal monthly distribution." The data base included 140.5 years, from 1850 through mid 1990. Analyzing the calendar years (January through December), and considering "normal" as $\pm 10 \%$ of the mean, both for annual and monthly data, the high variability of the region's rainfall became even clearer.

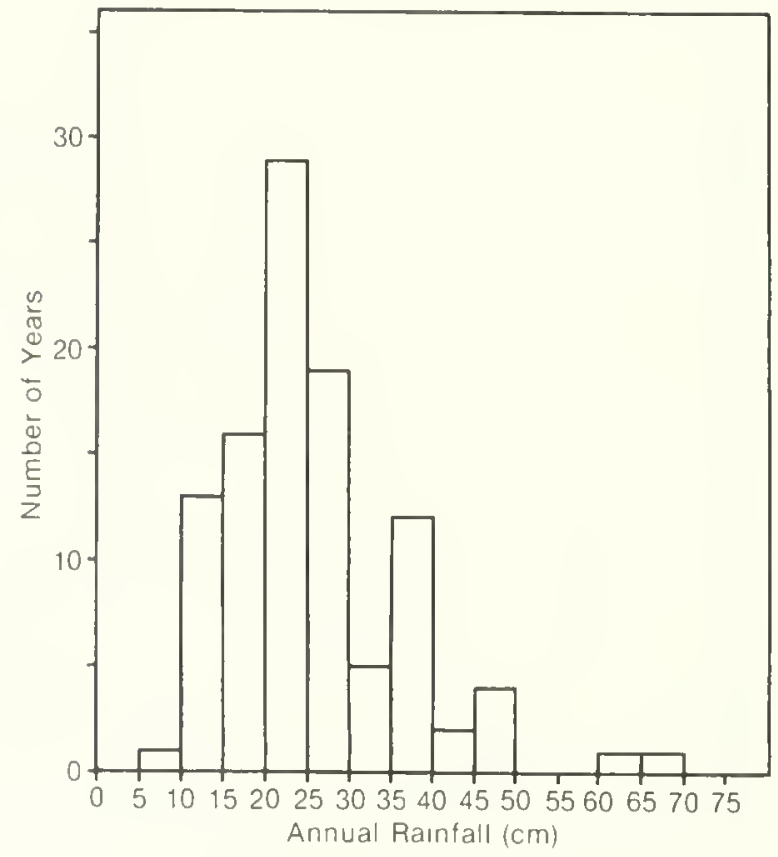

Figure 2.5. Histogram of annual rainfall for San Diego (Lindbergh Field) 1880-1984. Mean annual rainfall for this period $=25.87$ $\mathrm{cm}(\mathrm{n}=105)$.

Few years had $90-110 \%$ of the annual rainfall in this long-term record; only 21 years, or $15 \%$ of the historic record, qualified as being within $10 \%$ of the mean. To assess monthly distributions, the data were examined for successive months, beginning in January. Only 11 years ( $8 \%$ of the record) had January rainfall that fell within $10 \%$ of the 141-year average. Of these 11 years, only 5 had February rainfall that was within $10 \%$ of the mean. Of these 5 years, none had March rainfall that was within $10 \%$ of the 141-year average. Thus, not one of the 141 years qualified as having "normal monthly distribution." 


\subsection{LAND USE HISTORY}

Through examination of maps, photographs, and historical records, it has been possible to identify critical events that have shaped Tijuana Esluary. The many changes in land use reflect attitudes about the landscape. The estuary has been used and abused by a variety of human activities, exacerbating the effects of natural catastrophic events.

The 1904 map (Figure 2.3) shows Tijuana Estuary as having a minor bay and a

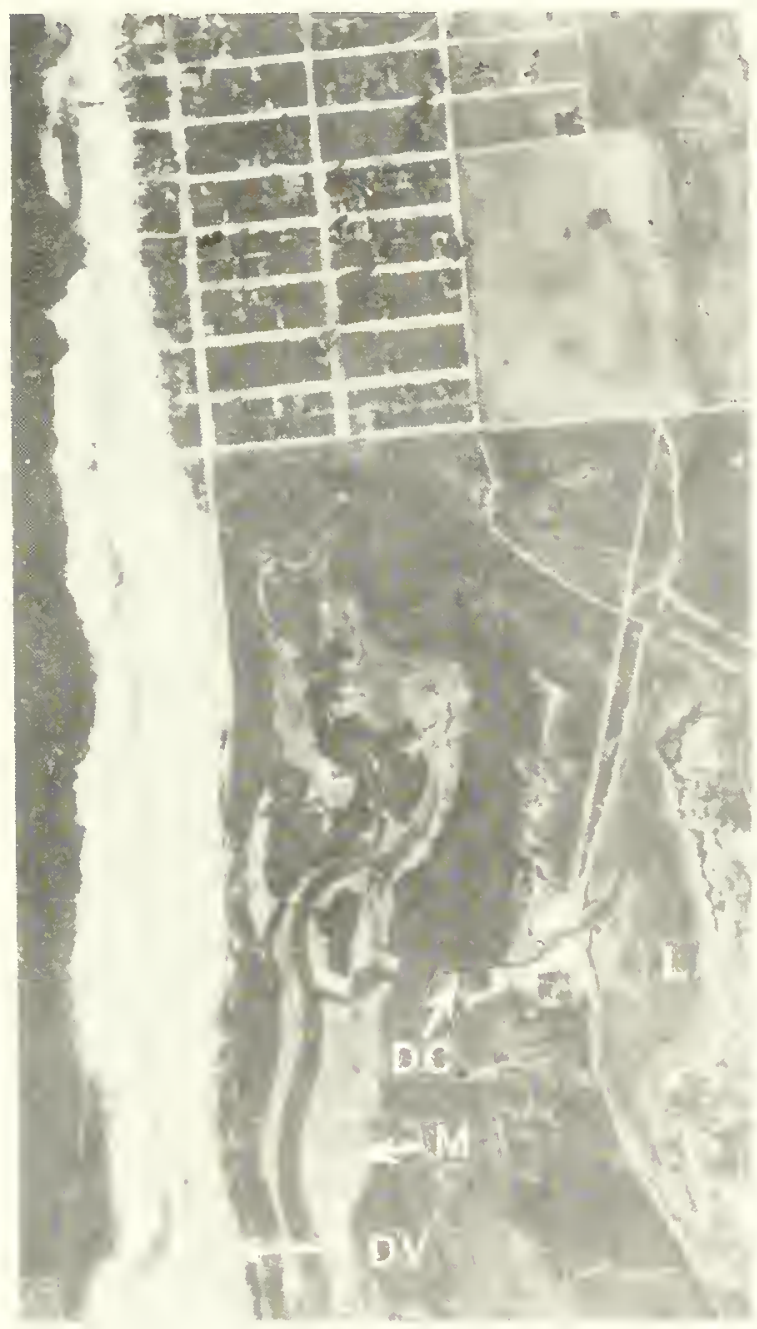

a broad mouth. The Tijuana River had two channels, one near the southern bluffs that border Mexico and another due east of the mouth. An isolated, land-locked lagoon was located in the northeastern part of the estuary. These three features persist to date, but in highly modified form.

By 1928 (Figure 2.6), Imperial Beach had been settled with more than 50 dwellings, most of which were within 3 blocks of the beach. The impact of adjacent land uses on the estuary become apparent on inspection of the condition of the river mouth, barrier dunes,

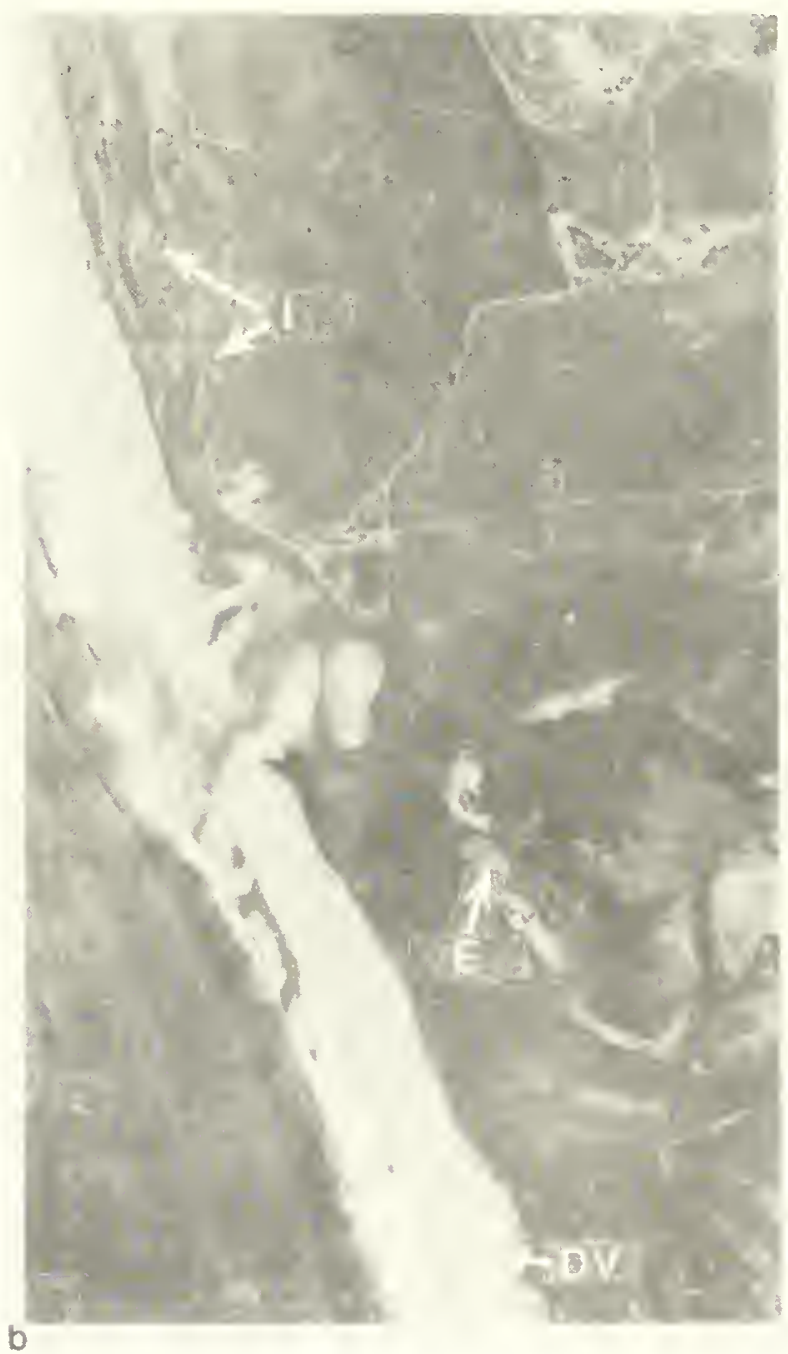

Figure 2.6. The 1928 aerial photograph of Tijuana Estuary (from County of San Diego). Left: northern arm of the estuary; right: the central embayment (E). Note dune vegetation (DV), mudflats (M) along tidal channels, islands (I), inland lagoon (L), and dredged channel (DC). 
channel edges, high marsh habitats, wetlandupland Iransitions, inland lagoon, and the adjacent upland. Several roads were present around the periphery of the wetland. However, there was only a path and no houses on the barrier dune adjacent to the salt marsh. Signs of agriculture in the floodplain are evident upstream of the estuary and north of what is now Monument Road.

Several physiographic features that changed in later years are noted in the photos of 1928, 1953, 1964, 1970, 1984, and 1985. In 1928 (Figure 2.6), the dune had intermittent vegetation extending from what is now Imperial Beach Blvd. south to the estuary mouth. This is consistent with Purer's (1936) description of a rich flora that included shrubs such as lemonadeberry (Rhus integrifolia). Channels had major bare mudflats along their periphery. The inland lagoons clearly contained marsh vegetation throughout. Only a small area of channel is visible, and that was dredged to link the lagoon with the estuary. Two islands were present in the main north-south channel. The mouth (Figure 2.6) had tidal flushing through an opening that angled southwest. A relatively large embayment was located south of the mouth, although it may have been shallower than indicated on the 1904 map (Figure 2.3). What appear to be large salt pannes were present east of the the inland lagoon.

By 1953 (Figure 2.7), many changes had occurred both in the periphery of the estuary and within the area of tidal influence. Imperial Beach was a well-populated community: a military airport had been built east of the estuary; military activity was evident along the southernmost portion of the beach; and agricultural activities had proceeded to within a few blocks of the beach.

Within the estuary, several habitals had changed dramatically. The barrier dune had begun to be developed for housing along the northwestern part of the estuary, although dune vegetation was still present farther south. Salt marsh vegetation had established along the edges of the channels. A sewage. treatment plant had been built north of the inland lagoon, and the northernmost depression had been diked to create a sewage pond. Presumably, the dredged channel carried the overflow to the ocean. A bridge had been built over the dredged channel, probably to truck gravel from shallow pits just south of the inland lagoon. The mouth was

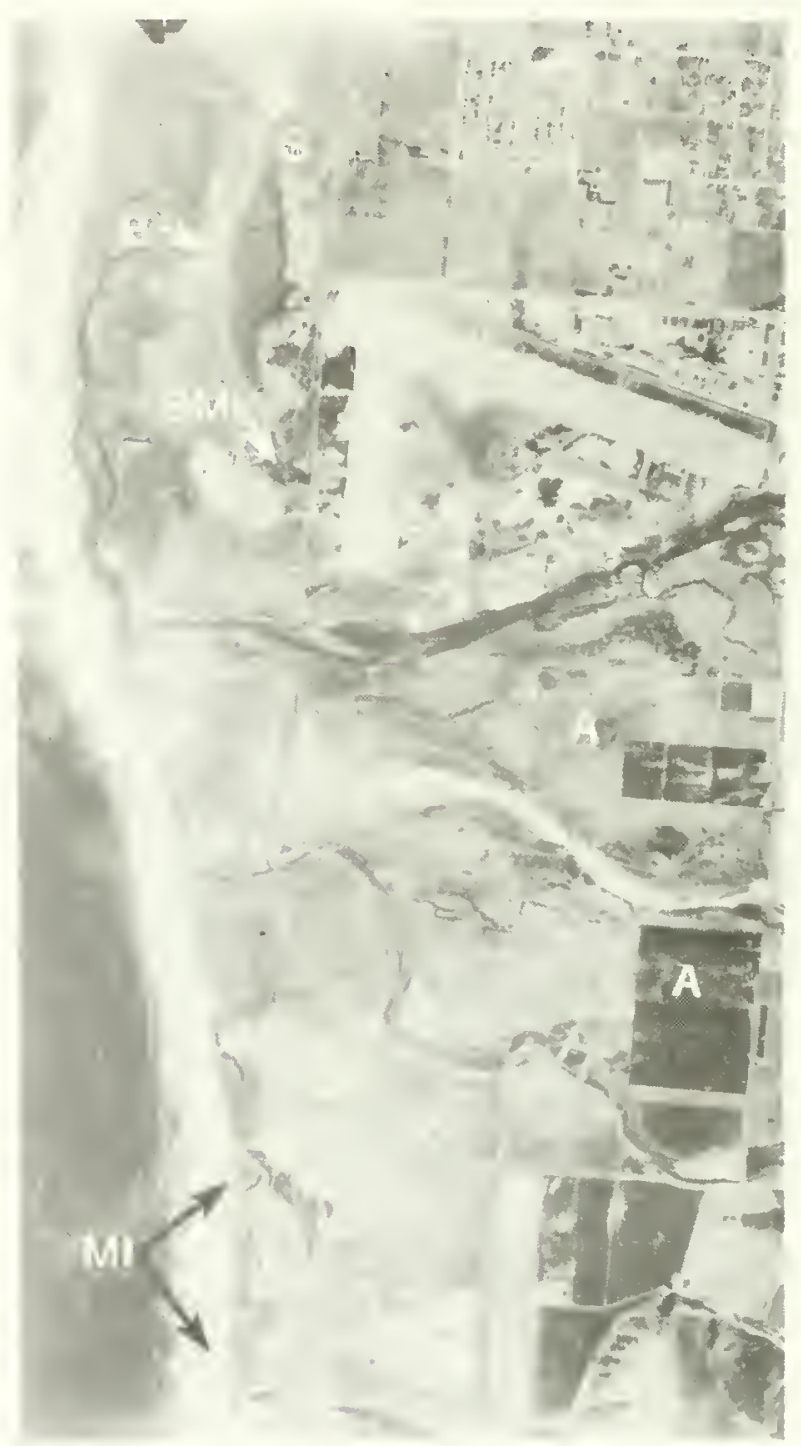

Figure 2.7. The 1953 aerial photograph of Tijuana Estuary (from U.S. Dept. of Agriculture). Note bridge (B) over the dredged channel, sewage oxidation pond (S), brackish marsh (BM), military installations (MI), and agricultural uses (A). 
still open to tidal flushing through an opening that had migrated south of its 1928 location. Much of the area that was deep-water habitat appeared to have filled in with beach sand, and the southern channel had become constricted. Salt pannes were still evident east of the inland lagoon, but a brackish marsh had appeared at the terminus of urban drainage from the airport, perhaps in a depression caused by excavation. Additional disturbance caused by gravel extraction was evident just west of the new wetland area.

Changes that took place in the 1960's and 1970's were described using additional air photos; for the most part, changes remained visible in the 1978 photo (Figure 2.8). By 1964, apartment buildings had been constructed along the beach, extending south to their present limit. Dune vegetation remained

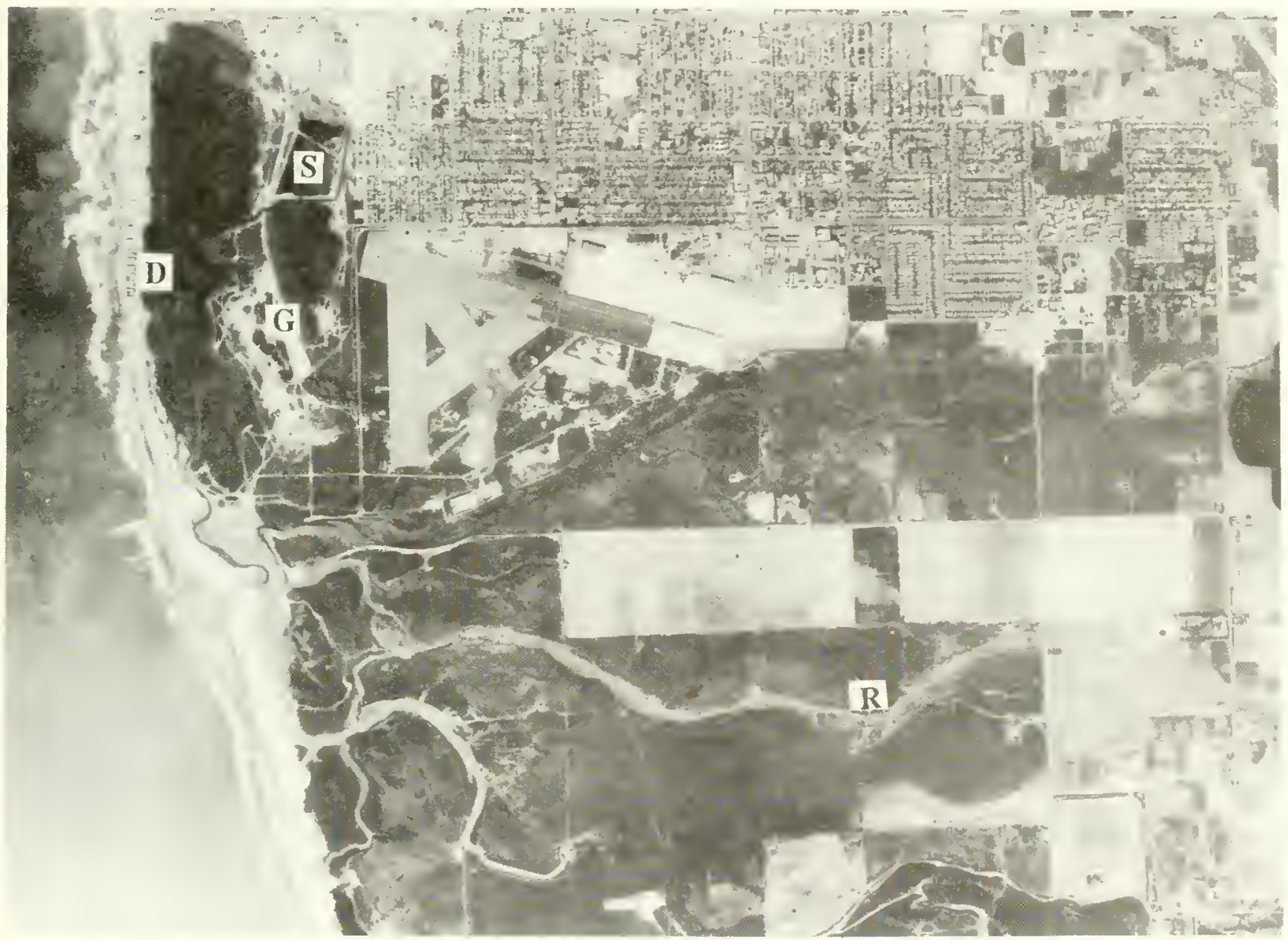

Figure 2.8. The February 18, 1978, aerial photograph of Tijuana Estuary (from Aerial Fotobank). Note development on beach (D), abandoned sewage oxidation ponds (S), gravel excavation (G), agriculture (A), and location of main river channel (R). 
relatively dense south of the apartments. Near the mouth were disturbed areas and areas of bare sand toward the main estuary channel. A second dike had been built within the inland lagoon. Sewage was then discharged to two oxidation ponds before overflowing to the estuary. The nearby bridge remained, and extensive disturbance by vehicle traffic had occurred.

By 1970 several new disturbances were visible. Additional apartments had been built along the coast, and the barrier dune no longer supported good vegetative cover. Large areas of dune washover had developed both north and south of the estuary mouth. As is obvious from events of the 1980's, this relatively gradual loss of dune vegetation ultimately had an estuary-wide impact. The sewage operation at the inland lagoons had been abandoned, and saline pannes were obvious during the July, dry-season photo. Tidal flushing was lacking behind the diked areas. The mouth had shifted southward. East of the sewage impoundments, a channel had been dug to direct street runoff into the southernmost lagoon.

The year 1983 was one of the strongest $E I$ Niño events on record (R. Flick, Scripps Inst. of Oceanography, pers. comm.). Associated with the warmer sea temperatures were higher sea levels (15 cm above average) and frequent storms. The storm activities were evident at the estuary.

In January 1983, concurrent high tides and heavy surf flooded Sea Coast Drive and washed sand between the apartment buildings into the street and onto the edge of the salt marsh. Where dune vegetation had been disturbed, there were major washovers. The photo from March 1984 (Figure 2.9) documents the effects of the winter storms on the barrier beach, while that of August 1984 (Figure 2.10) shows the delayed effect on the estuary mouth. Dune sands were washed into the main estuary channel, substantially reducing the lidal prism and ultimately causing the closure of Tijuana Estuary to tidal flushing. Closure occurred on or about April 8, 1984, after which a dredging plan was developed and implemented by the U.S. Fish and Wildlife Service. Excavation of the sand from the main channel began after a long permit process, but the estuary was not reopened to tidal flushing until mid-December 1984. Eight months of closure had devastating effects on the estuary.

While the reduction of tidal flushing is in itself a catastrophic event for a marinedominated system, the situation was made worse by its coincidence with a year of nearzero rainfall. Channels became hypersaline (60 ppt in fall 1984; R. Rudnicki, SDSU, pers. comm.), shallow creek bottoms desiccated and turned 10 brick, and marsh soils became so dry and hypersaline (over $100 \mathrm{ppt}$ in September 1984) that large areas of low-marsh vegetation died out (Figure 2.11). Bare patches within the salt marsh were obvious from the air in August 1984 (Figure 2.10).

Tidal flushing was reinstated in December 1984 after dredging of the main estuary channel from the end of Sea Coast Drive south to the mouth, and tidal flushing has continued to the present. Sand that washed eastward was bulldozed back 10 recreate dunes, which are now part of a dune revegetation program. Additional dredging in the south arm of the estuary was done in 1986, along with dune rebuilding activities.

In comparison with earlier estuary conditions, several changes had occurred by 1985 (Figure 2.12). Native dune vegetation was almost entirely gone both north and south of the mouth. Along the channels, salt marsh vegetation that died back in 1984 had begun to recover in 1985, although species composition had changed (Chapter 5). Dikes that once separated the sewage lagoons had been breached and widened (Chapter 6). The islands in the main channel were obliterated by the sand washover of 1983. The mouth was artificially cut; and south of the new mouth, it is clear that the beach line had moved inland. What was once a shallow embayment became the beach line, and only a narrow channel remained. Control of vehicle traffic along the urban periphery of the estuary had allowed some vegetation regrowth.

Disturbances that occurred south of the estuary mouth in the 1960's left scars that 
were still apparent in 1985. Near the Border Field State Park overlook, areas used to corral horses and an exercise track used to rehabilitate race horses have been slow to recover. Twenty years later, the highly compacted soils support only limited vegetation. Military installations, shown as

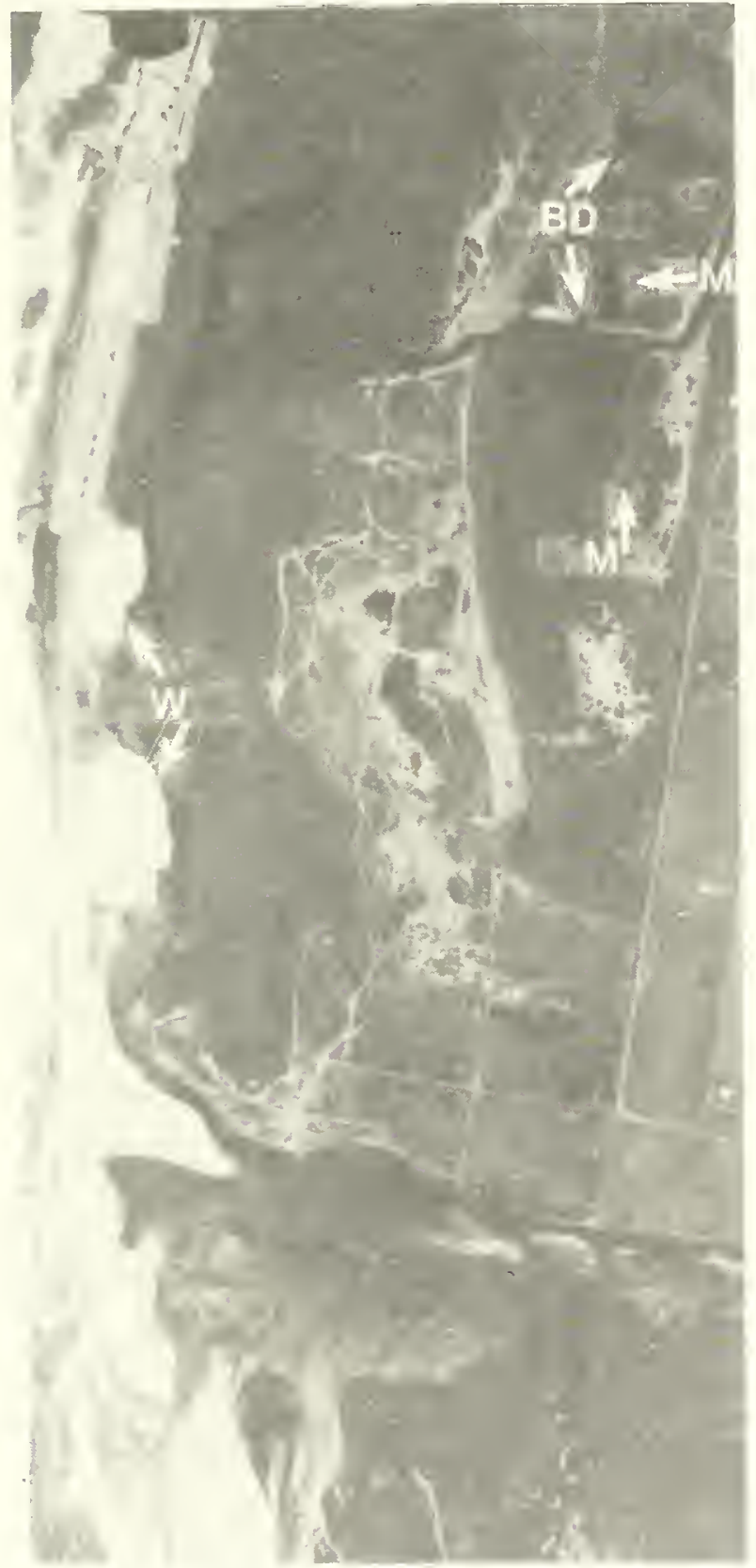

Figure 2.9. The March 19, 1984, aerial photograph of Tijuana Estuary (U.S. Army Corps of Engineers). Note washovers (W), macroalgal blooms (M), breached dikes (BD), and southerly location of mouth just prior to closure. irregular circles in the 1953 aerial photo (Figure 2.7) were filled with sands washed from the beach and dune during the 1983 storm. Standing water accumulated east of the road to the overlook, allowing establishment of brackish marsh vegetation in that area.

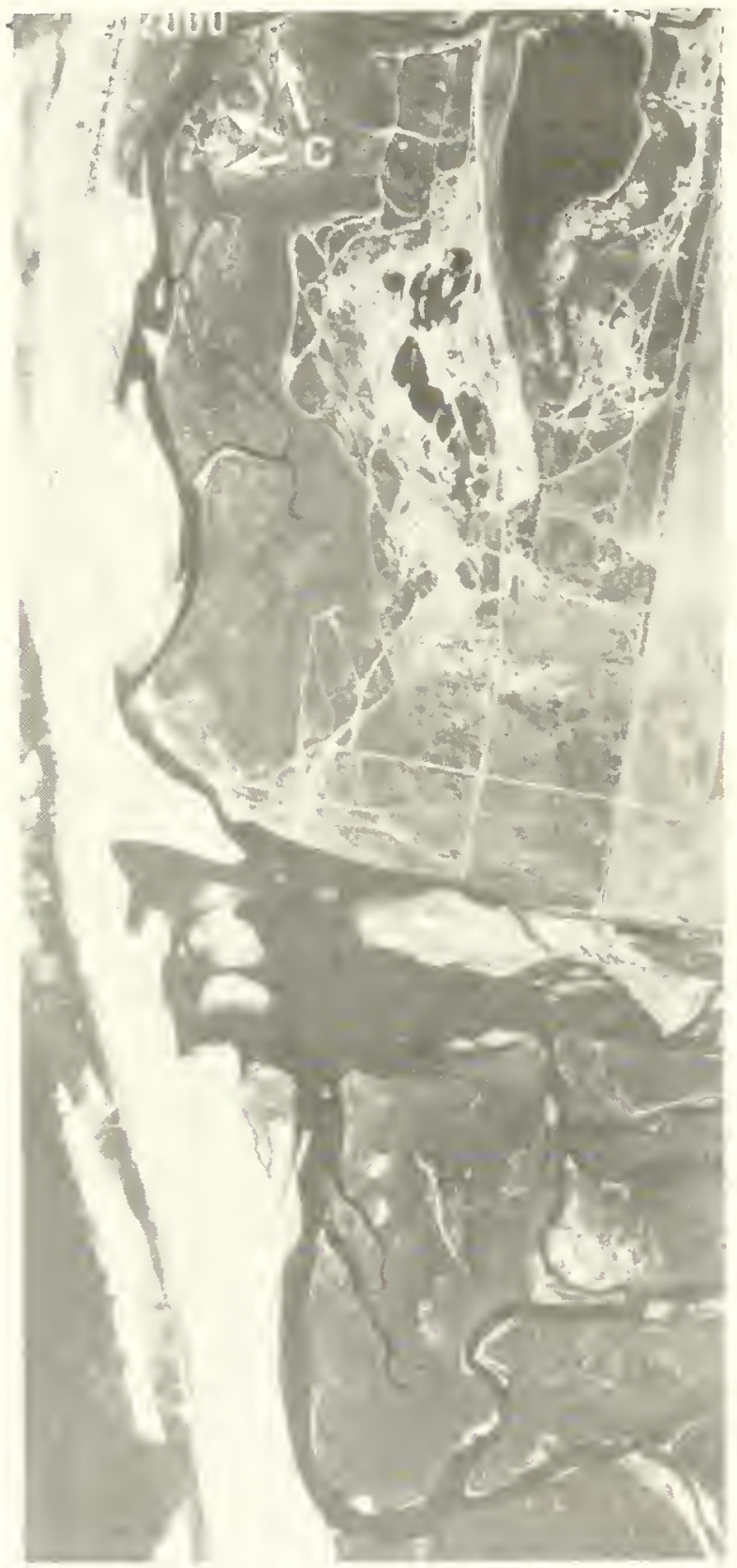

Figure 2.10. The August 30, 1984, aerial photograph shows the estuary after nearly 5 months of closure to tidal flushing (from U.S. Army Corps of Engineers). Note patches of cordgrass mortality (C) near tidal creeks. 


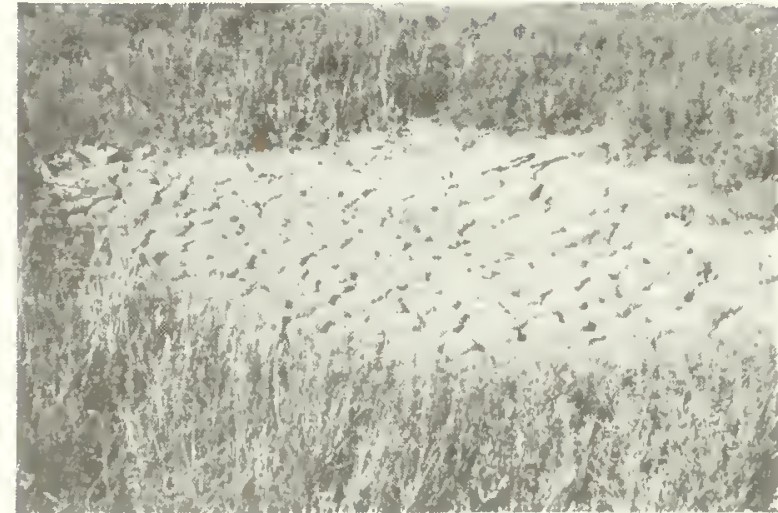

Figure 2.11. Cordgrass mortality during nontidal conditions in 1984 (photo by $\mathrm{J}$. Zedler).

\subsection{STREAMFLOW HISTORY}

Streamflow in the San Diego region is the most variable in the United States, and differences between wet and dry years are greater than in any other part of the country (Pryde 1976). Even small variations in streamflow affect the coastal wetlands, because floodplains are narrow, and there is little volume of estuarine water present to ameliorate the impacts of increased or decreased flows.

The Tijuana River drains a watershed of 448,323 ha, three-fourths of which is in Mexico (Figure 1.1). Of that watershed, $78 \%$ is behind dams (IBWC 1983). The effects of reservoirs on streamflow are undetermined, because all three dams were installed before streams were gaged. Morena Dam dates to 1912, Barrett to 1922, and Rodriguez to 1936. Their respective capacities are 62 million $\mathrm{m}^{3}(50,210$ acre- $f), 55$ million $\mathrm{m}^{3}$ $\left(44,760\right.$ acre-ft), and 138 million $\mathrm{m}^{3}$ $(111,880$ acre-ft). The largest and closest to Tijuana Estuary is Rodriguez Dam, just upstream of the city of Tijuana. It is likely that dry-season flows are lower and that flood flows are delayed by the presence of these reservoirs.

Flows of the Tijuana River have been measured since 1937 at the Nestor gage, which includes $99.6 \%$ of the watershed (Figure 1.1). On the average, the Tijuana River has its peak flow in March (Figure 2.13). However, as with rainfall data, averages tell little of the relationship between streamflow and estuarine dynamics. Year-toyear flows are highly variable (coefficient of variation $=325 \%$ ), as are monthly flows (c.v. $=690 \%$ ). With such a streamflow history, Tijuana Estuary may be the Nation's most variable estuary. If is marinedominated on a seasonal basis (sometimes for several years in succession); it is occasionally fresh during calastrophic flooding, such as occurred in 1980.

\subsubsection{Major Flood Events}

Monthly flow volumes at Nestor (Figure 2.14) show that major floods occurred in 1978 and 1980 after a 35-year period with little flow. Log-transformations of the monthly streamflows enhance the years of low flow and de-emphasize high-flow years. Seasonal patterns become much clearer with such transformation, and the winter-flow, summer-drought pattern becomes obvious. Note, however, that several entire years had zero flow at the Nestor gage. During these times, the estuary is presumed to have been filled entirely with seawater. Even in years with seasonal streamflow, the predominant influence has been marine.

In January and again in February of 1980, floods that exceeded all previous flow records simultaneously eroded and filled different parts of the estuary. The Jan.-Dec. total flow of 725.4 MCM (million cubic meters) was $18.6 x$ the average yearly volume. The flooding shifted the course of the Tijuana River from its Mid-Valley channel (Figure 2.8) across several parcels of agricultural land, carving a diagonal channel toward the helicopter landing field, where it connected with the central estuarine channel. A much broader coastal embayment was created at the river mouth. Major sedimentation occurred in the southern half of the estuary. Monument Road was buried by half a meter of silt that flowed down Goat Canyon. 


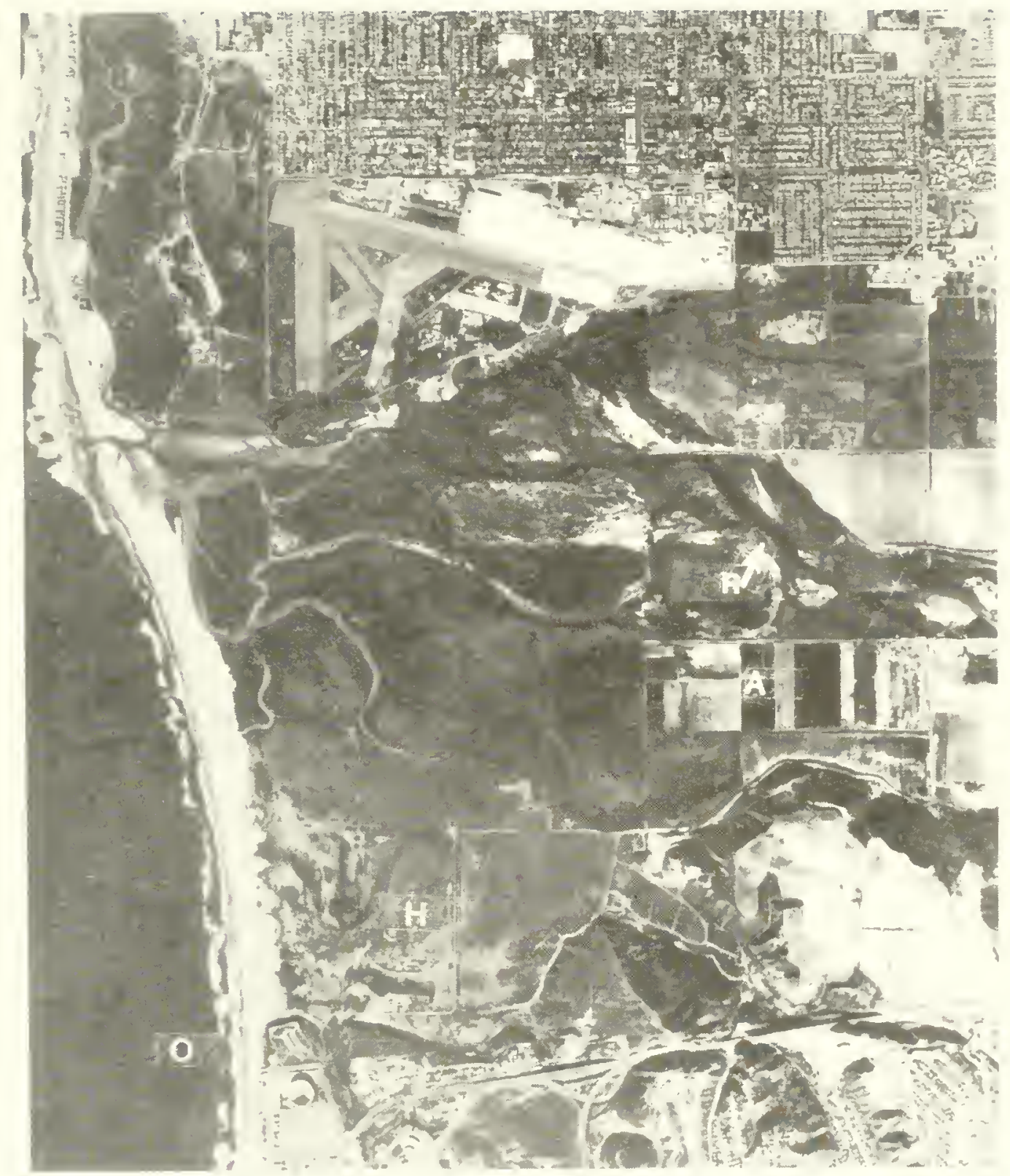

Figure 2.12. Tijuana Estuary on January 1, 1985 (from Aerial Fotobank). Compare locations of main river channel (R) and agricultural activities (A) with Figure 2.8. Traces of horse-raising activities $(H)$ are visible near the Border Field State Park overlook (O). Estuarine habitat types, drawn from this photo, are mapped in Figure 1.3.

Another major flood period occurred in 1983, when streamflows were above average in February and of record volume from March through December. Rainfall was $2.4 x$ average in February, 3.8x average in March, and 2.3x average in April 1983 (at Tijuana, Baja
California, Mexico). Inflows to Rodriguez Reservoir were over $10 x$ average during 1983. Heavy streamflows in winter and spring were the immediate effect of rainfall; the high summer flows were due to discharges from Roóriguez Reservoir. Flows in 1983 
(Jan.-Dec. total $=603.7$ MCM) were nearly as high as the 1980 record, but the distribution differed. The 1980 flood peaked in February, while the 1983 flows were highest in March and remained high through summer and fall.

While floods are the exception in the streamflow record, they have an enormous influence on the estuary. Not only does the river change its course with some floods, but sedimentation fills channels, raises the level of the mudflats and marsh plain, and gradually reduces the tidal prism (Section 2.4.3). Because the lidal prism is now small, freshwater input during storm events can have far-reaching effects on the system. From the floods of 1978 and 1980, we have learned how dramatically water salinities change, how rapidly the invertebrate populations shift, and how extensively the marsh soils and vegetation are affected by these unusual events (cf. Chapter 5). Though floods are usually brief, they are catastrophic in their effect. What we see at any given time is the estuary's cumulative response since the last major event.

\subsubsection{Wastewater Inflows}

From the early 1980's through 1991 , wastewater flows became a continuous problem at Tijuana Estuary. Almost all of the polluted water came from the City of Tijuana, Baja California, Mexico. This upstream metropolis produces far more sewage than its wastewater system can handle. It has a population of over a million, and a doubling time of about ten years.

In 1988, about 30 MGD of sewage was produced by Tijuana and only 17 MGD collected; the remainder ( $\sim 13$ MGD) flowed down Tijuana River loward the estuary (Seamans 1988). On occasion, there have been breaks in the Tijuana sewer line, which carries the collected sewage to an ocean discharge. Depending on the location of the break, sewage flowed down Smugglers' Gulch and entered the Tijuana River or down Goat Canyon and directly into the nontidal salt marsh at the southern end of the estuary. In
1988, an interceptor was built to collect and return flows down Smuggler's Gulch, but it has overflowed on numerous occasions.

Recent U.S. projects have reduced the threat of sewage contamination considerably. An interceptor on the Tijuana River was completed in early October 1991. A sewage treatment plant is being planned for the U.S. side of the border, and a new ocean outfall is under evaluation. Final solutions await the impact analysis and permitting procedures.

\subsubsection{Tidal Prism}

The estuary has been characterized as having a low tidal prism, with a range of from 0.1 to 3.7 MCM (100-3,000 acre-ft; IBWC 1976). However, the terminology is confusing, and it is not always clear what is being estimated. Diurnal tidal prisms are the volume between MLLW and MHHW. Mean tidal prisms are lower than diurnal tidal prisms, and extreme monthly tidal prisms are higher than both of the above. In addition, calculations of tidal prism from topography (potential tidal prism) exceed those determined by measuring flows (effective tidal prism).

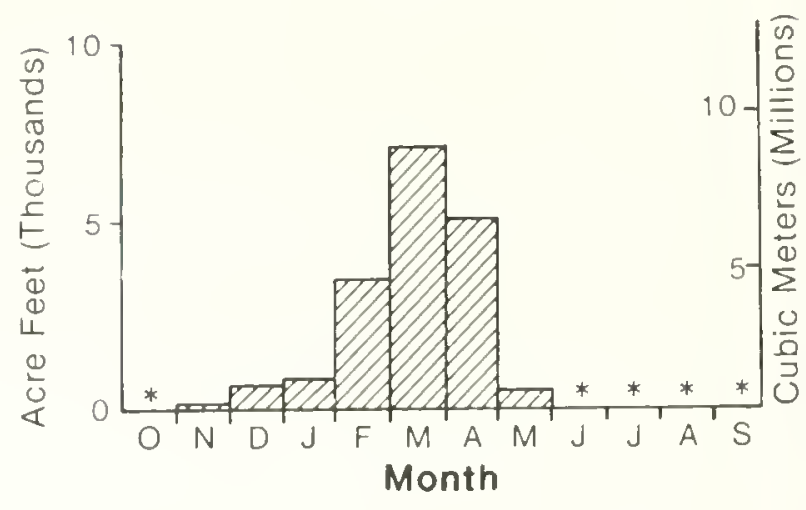

Figure 2.13. Average monthly streamflow at Tijuana River. Asterisks indicate months with average flows $<100$ acre-ft (Nestor gage; data from USGS 1937-1978). 
At Tijuana Estuary the ocean inlet is relatively shallow, so less water flows in and out with the tides than would potentially fill the internal channels and basins. Measurements in 1987 (Williams and Swanson 1987) indicated that water levels rarely drop below NGVD (National Geodetic Vertical Datum, or the 1929 Mean Sea Level); hence, the effective tidal prism is less than the potential. Williams and Swanson (1987) calculated that the potential tidal prism is about $0.30825 \mathrm{MCM}(250 \mathrm{ac}-\mathrm{ft})$. Of that calculated volume, $50 \%$ is in the northern arm (Oneonta Slough).
Changes in the tidal prism were evaluated by Williams and Swanson (1987). From the 1852 map it was calculated that the estuary had a potential diurnal tidal prism of 2.018 MCM (1650 ac-ft) in historic times. The $80 \%$ loss that occurred by 1986 was explained as the cumulative impact of several events (Figure 2.15), most of them recent: sedimentation from river inflows, sedimentalion from Goat Canyon, man-made filling, landward migration of the beach, and accretion along the Oneonta Slough. Mudflats along the channel became vegetated with salt marsh plants.
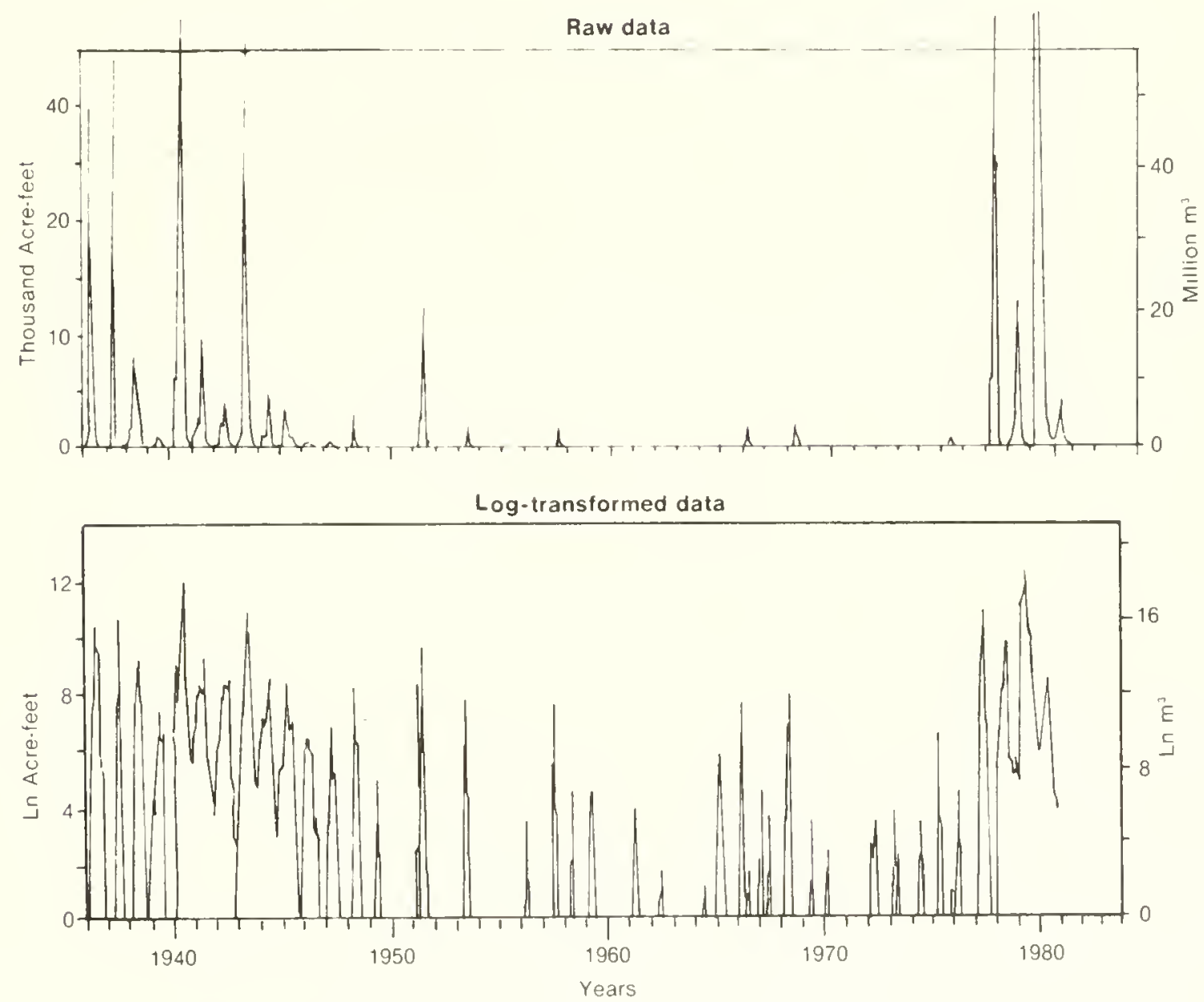

Figure 2.14. Streamflow data for Tijuana River (Nestor gage). Log-transformed data are given to emphasize low-volume flows (data from USGS 1937-1981 and IBWC 1950-1983). 


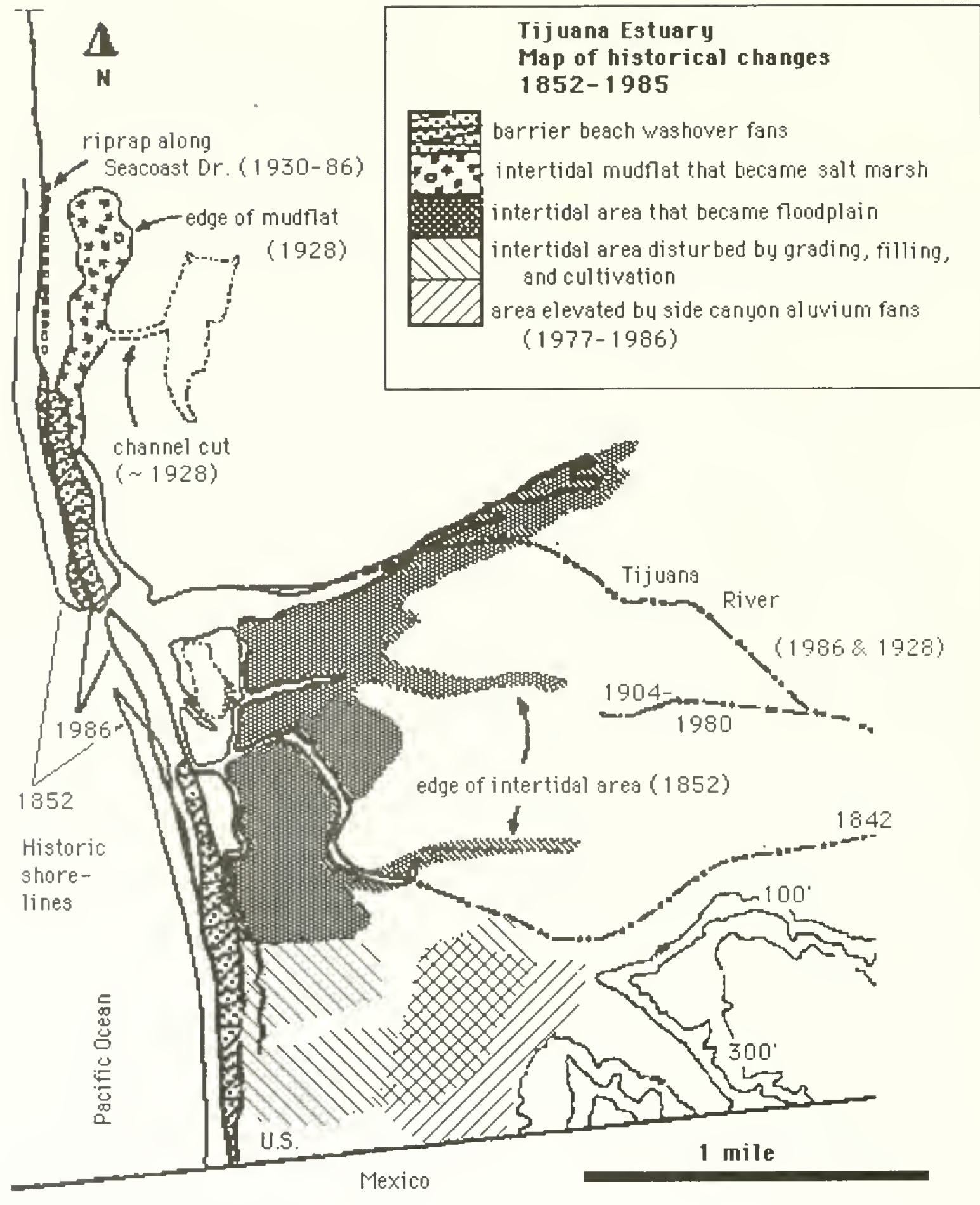

Figure 2.14. Historic changes that have reduced the tidal prism of Tijuana Estuary. Modified from Williams and Swanson (1987). 


\section{CHAPTER 3}

\section{ECOLOGICAL COMMUNITIES AT TIJUANA ESTUARY}

The diversity of habitats at Tijuana Estuary results from the variability in topography, tidal influence, and streamflow inputs. This chapter describes the major communities of organisms at the estuary; additional information on their relationships to other wetlands in southern California is provided in Zedler (1982b).

\subsection{PHYSIOGRAPHIC DIVERSITY}

Tijuana Estuary includes eight major natural habitats that we have named: transition from upland to wetland, riparian, salt marsh, salt panne, brackish marsh, estuarine channels and tidal creeks, intertidal flats, and dunes and beach (Table 3.1). Of the wetland habitats, the three that cover the largest area are salt marsh, channels and tidal creeks, and dunes and beach (Table 3.1). Most of the estuarine research has focused on the salt marsh habitat. Regional comparisons of salt marshes appeared in Zedler (1982b). In this chapter, we characterize the dominant species of plants and animals for each habitat and highlight species of special concern.

Small variations in hydrology and elevation are responsible for the physiographic diversity of Tijuana Estuary (Figure 1.3). Even though the estuary has been substantially altered by catastrophic events and human disturbances, most of the habitats present today probably represent variations on what existed at the turn of the century. One likely exception is the brackish marsh habitat, which appears to be directly dependent on urban runoff. Another is the transition zone, which has borne the brunt of urban and agricultural encroachment. Just how closely it resembles the natural condition
Table 3.1. Habitat types and areas within the National Estuarine Research Reserve, as determined from the 1986 aerial photo, the 1988 vegetation mapping effort, and the geographic information system (Entrix et al. 1991).

\begin{tabular}{lrrr} 
Habitat type & AC & \multicolumn{1}{c}{ Ha } & \multicolumn{1}{c}{$\%$} \\
\hline & & & \\
Dunes \& beach & 124 & 50.2 & 4.9 \\
Channels \& ponds & 173 & 70.0 & 6.8 \\
Mudflats & 33 & 13.4 & 1.3 \\
Salt marsh & 176 & 71.2 & 7.0 \\
Salt marsh/salt panne & 439 & 177.7 & 17.3 \\
Transition & 610 & 246.9 & 24.1 \\
Disturbed (e.g., agric.) & 366 & 148.1 & 14.5 \\
Transition/disturbed & 181 & 73.2 & 7.2 \\
Brackish marsh & 30 & 12.1 & 1.2 \\
Riparian & 248 & 100.4 & 9.8 \\
Coastal sage & 151 & 61.1 & 6.0 \\
& & & \\
Total & 2531 & 1024.3 & 100.0 \\
\hline
\end{tabular}

will never be known, because there are no remnant areas where undisturbed coastal scrub grades into undisturbed coastal wetland.

With or without human disturbance, none of the estuarine communities is viewed as static in either species composition or population sizes. Our knowledge of community change is limited by the lack of consistent sampling of most habitats. However, for the most extensive community, the salt marsh, there is now a 10-year record that allows discussion of vegetation dynamics (Chapter $5)$. This data base and the record of variable climatic conditions and streamflow regimes make it clear that Tijuana Estuary is continually subject to environmental 
variation. The result is a mosaic of populations that are constantly shifting in space and time.

These long-term patterns of habitat change have been revealed only recently; they are emphasized here because they are not obvious upon short-term observation. Other dynamic aspects of the estuary are more easily documented. These are the daily and seasonal flucluations in tidal height, the alternation of wet and dry seasons that creates pools in winter and salt pannes in summer, the seasonal patterns of temperature that stimulate development of macroalgae in the inland lagoons and tidal creeks, and the migration of birds that use the intertidal flats in winter but not in midsummer. Each community must be viewed as a function of its changing physical environment, as well as a complex mixture of interacting species.

\subsection{TRANSITION FROM UPLAND TO WETLAND}

By definition, transitions are areas where one community type (e.g., upland) shifts to another (e.g., wetland). The most extensive welland habitat at Tijuana Estuary is the intertidal salt marsh. Its exact upper boundary is difficult to discern, because the vegetation blends into that of the upland. The two communities overlap in a transitional area that has elements of both (Figure 1.3).

Most of the peripheral upland has been disturbed at Tijuana Estuary. The best information on what these areas might have been like naturally comes from Baja California (Neuenschwander 1972). Al Bahia de San Quintin $\left(30^{\circ} 25^{\prime}\right.$ N., $116^{\circ} 00^{\prime}$ W. $)$, we analyzed the transitional vegetation in detail to determine at what point one leaves the upland and enters the wetland (Zedler and Cox 1984). There, the wetland plants that occurred highest along the slope were alkali heath (Frankenia grandifolia), sea lavender (Limonium californicum), and sea-blite (Suaeda esteroa). The upland plants that were found farthest downslope were two species of box-thorn (Lycium spp.) and Frankenia palmeri. In California, the latter occurs only in San Diego Bay; whether or not it ever occurred at Tijuana Estuary is unknown. The box-thorn (Lycium californicum), however, is common in several of the remnants of Iransitional vegetation at Tijuana Estuary. It is easily recognized by its thorny, stiffIwigged appearance and small red berries. Like many shrubs of the coastal scrub community, box-thorn is drought deciduous. It is leafless during summer when the salt marsh vegetation is at peak biomass.

\subsubsection{Plants of the Wetland-Upland Transition}

A small remnant of the transition community persists in a sloped corner of the northern end of Tijuana Estuary. Because the slope is one of the most frequently used entry points for visitors to the estuary, a detailed description of upland-wetland compositional shifts has been developed. The area was sampled in 1984 (Table 3.2) with 396 quadrats spanning elevations from the street into the marsh. In this transition area, the upland community is coastal sage scrub with several shrub species, some of which are evergreen (e.g., laurel sumac, Rhus laurina; lemonadeberry, $R$. integrifolia; jojoba, Simmondsia chinensis), and some of which are drought-deciduous (e.g., golden bush, Haplopappus venetus; California sagebrush, Artemisia californica).

The data in Table 3.2 indicate a relatively abrupt boundary between upland and welland plants. The band of overlap is narrow because the topography is fairly steep. While many exolic plants have invaded the coastal scrub, few have sufficient tolerance of inundation and salt stress to invade the coastal wetlands. One weedy species, the Australian salt bush (Atriplex semibaccata), has an extremely wide range of tolerance. It occurs throughout the transition zone and well into the upper salt marsh. It withstands the dry saline upland as well as occasional inundation by seawater, and thus has been promoted for horticultural uses. Although its light foliage and bright red berries are attractive, further spread of this exotic species is of concern. 
Table 3.2. Percent occurrence of the more abundant species in the transition from upland to wetland at the northernmost part of Tijuana Estuary. Data are from $0.25 \mathrm{~m}^{2}$ circular quadrats (numbers sampled in parentheses) taken per $40-\mathrm{cm}$ elevation class (Zedler unpubl. data).

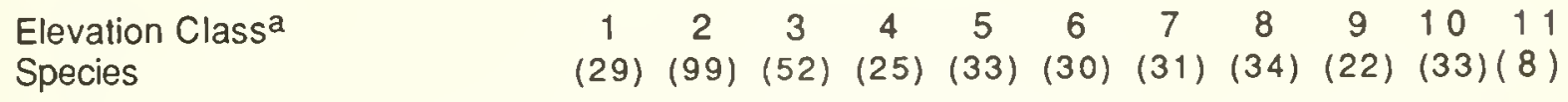

\begin{tabular}{|c|c|c|c|c|c|c|c|c|c|c|c|}
\hline Artemisia californica & & & & & & 7 & & 15 & & & \\
\hline Eriogonum fasciculatum & & & 2 & 4 & & 17 & 19 & 21 & 27 & 3 & 12 \\
\hline Haplopappus venetus & & & 6 & 4 & & 3 & 10 & 9 & & & \\
\hline Rhus laurina & & & & & 39 & & 13 & 6 & & & \\
\hline Atriplex semibaccata & & 14 & 15 & 16 & 12 & 3 & 52 & 3 & 27 & 39 & 75 \\
\hline Cressa truxillensis & 34 & 19 & 8 & 12 & & 3 & & & & & \\
\hline Distichlis spicata & 66 & 68 & 75 & 64 & 33 & 13 & 3 & & & & \\
\hline Frankenia grandifolia & 59 & 40 & 27 & 44 & 15 & & & & & & \\
\hline Lycium californicum & 14 & 3 & 12 & & & & & & & & \\
\hline Monanthochloe littoralis & 59 & 37 & 6 & 4 & & & & & & & \\
\hline Salicornia subterminalis & 41 & 44 & 23 & & & & & & & & \\
\hline Salicornia virginica & 52 & 17 & 14 & 24 & & & & & & & \\
\hline Limonium californicum & & 10 & & & & & & & & & \\
\hline Atriplex watsonii & & 4 & 6 & 4 & & & & & & & \\
\hline
\end{tabular}

aElevation classes each included a $40-\mathrm{cm}$ (16-inch) elevation range; they are numbered from low to high elevation.

The marsh species that grows highest up the slope is saltgrass (Distichlis spicata). Also found in sandy areas near the dunes, this marsh plant is easily mistaken for Bermuda grass (Cynodon dactylon) in vegetative form. Insects, however, know the difference. The saltgrass is the sole host plant for larvae of the wandering skipper (Panoquina errans, Lepidoptera: Hesperidae; Figure 3.1). The first occurrences of alkali weed (Cressa truxillensis) and alkali heath are additional indicators that you have moved from the upland down into the wetland. At the sloped corner, they first appear at approximately 3 $\mathrm{m}(9.2 \mathrm{ft})$ above MSL. While the habitat where the highest marsh plants occur is often dry, it becomes inundated when storms coincide with the highest spring tides (Cayan and Flick 1985).

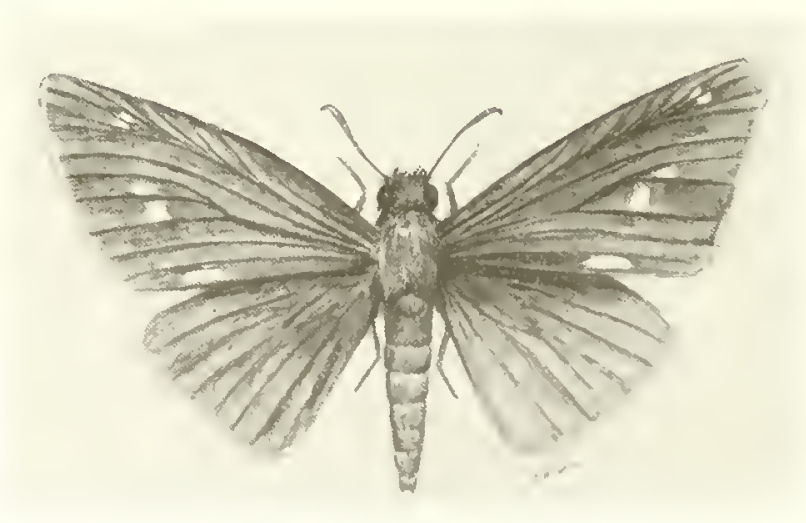

Figure 3.1. The wandering skipper. Body 14 $\mathrm{mm}$ long. Mclntire collection, (C) 1986 by Zedler. 


\subsubsection{Animals of the Wetland-Upland Transition}

The animals of the transition community include snakes, lizards, rodents, and birds. The herpetofauna was studied by Robert Espinoza for the tidal restoration plan (in Entrix et al. 1991). Most of the species found were located by observation, rather than trapping. California kingsnakes (Lampropeltis getulus californiae) and San Diego gopher snakes (Pituophis melanoleucus annectens) are common species that were seen in transition habitats. The side-blotched lizard (Uta stansburiana) was abundant on dry ground, especially in sandy, open areas.

Ernest Taylor and John Tiszler trapped small mammals monthly between November 1988 and May 1989 as part of the resource inventory for tidal restoration planning (Entrix et al. 1991). Two species were captured in the transition habitat (5 sampling plots with 10 trap stations per 0.04-ha plot), with $92 \%$ of the caplures being western harvest mouse (Reithrodontomys megalotis) and $8 \%$ deer mouse (Peromyscus maniculatus). The latter species was trapped only in May in the transition habitat. The combined density of these two species ranged from 0 (in December) to 15 (April and May) per hectare.

Other mammals were trapped or observed in the upland habitats around Goat Canyon; species included three carnivores, the coyote (Canis latrans), striped skunk (Mephitis mephitis) and the long-tailed weasel (Mustela frenata). The California jackrabbit (Lepus californicus), desert cottontail (Sylvilagus audoboni), opossum (Didelphis virginianis), and California ground squirrel (Spermophilus beechyi) were also observed. It is likely that these larger, highly mobile animals visit the wetland from time to time. Traps in the upland captured additional small mammals: agile kangaroo rat (Dipodomys agilis), San Diego pocket mouse (Perognathus fallax), cactus mouse (Peromyscus eremicus), brush mouse (Peromyscus boyli), and dusky footed woodrat (Neotoma fuscipes).

The small mammal species are no doubt prey for various birds. Of special interest in the transition habitat are the short-eared owl (Asio flammeus), northern harrier (Circus cyaneus), and black-shouldered kite (Elanus caeruleus).

\subsection{INTERTIDAL SALT MARSH}

While the salt marsh appears to be a plant-dominated community, it provides habitat for a wide variety of animals, including resident and migratory species. Large shorebirds feed and rest in the marsh, while smaller shorebirds use the marsh as a nocturnal roosting site. Insects and benthic invertebrates are likewise abundant in the intertidal marsh. The plants structure the community and support a complex food web.

Espinoza (in Entrix et al. 1991) found the Greal Basin fence lizard (Sceloporus occidentalis biseriatus) to be abundant where soils were drier. It prefers open areas with mounds of soil or debris for perching and territorial display. California kingsnakes and San Diego gopher snakes were also found in drier areas of glasswort (Salicornia subterminalis), pickleweed (S. virginica) and salt grass (Distichlis spicata).

The salt marsh vegetation changes gradually with elevation, and can be depicted as a series of overlapping distributional curves (Figure 3.2). Almost every species has its peak occurrence at a different elevation band, and the vegetation forms a continuum rather than a set of zones. Still, the presence of shrub-like succulents at the uppermost elevations (Figure 3.3) and the taller cordgrass (Spartina foliosa) at the lowest elevations helps to designate higher and lower marsh habitats. Unlike the droughtdeciduous coastal scrub species, the plants of the salt marsh grow through the summer and early fall. Presumably, this is because the wetland plants have access to moisture from tidal waters throughout the dry summer and fall.

Small mammals also use the drier areas of salt marsh. According to Taylor and Tiszler (Entrix et al. 1991), the western harvest 

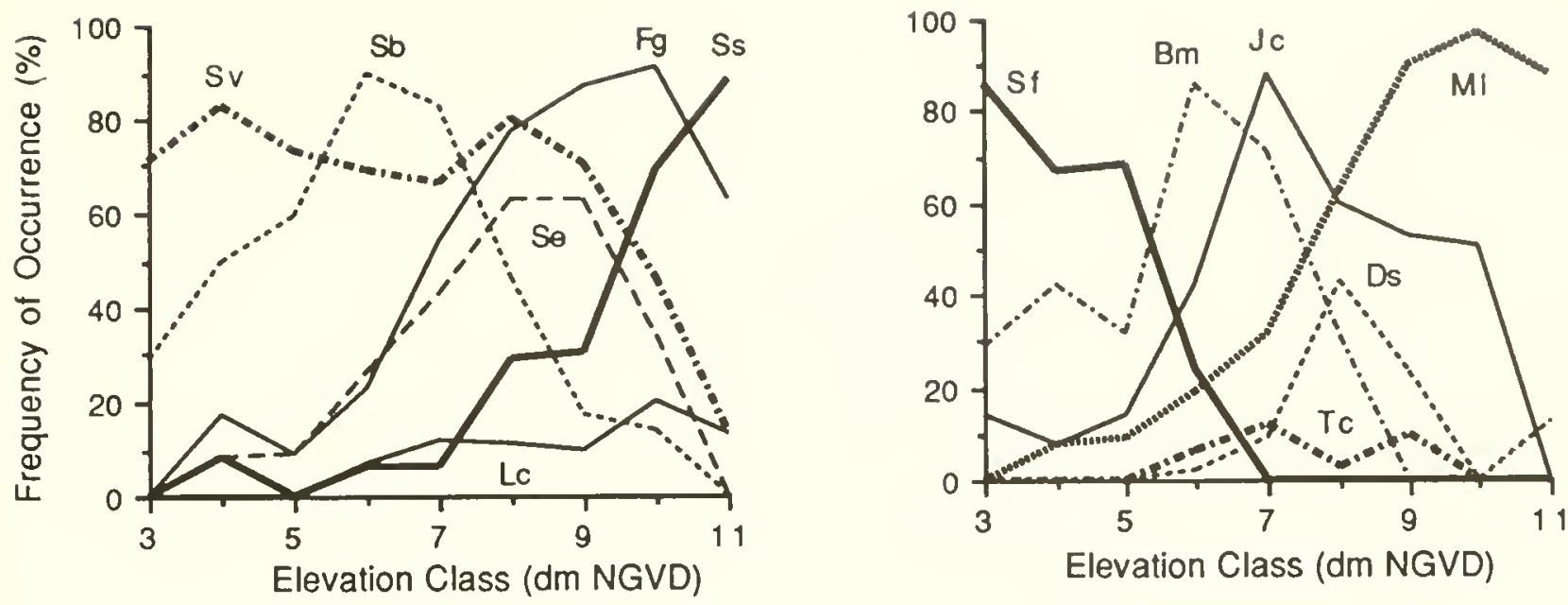

Figure 3.2. The frequency of occurrence of abundant plant species in the salt marsh of Tijuana Estuary (from Zedler 1977). Sv=Salicornia virginica, $\mathrm{Sb}=S$. bigelovii, Fg=Frankenia grandifolia, $\mathrm{S} s=S$. subterminalis, $\mathrm{Se}=$ Suaeda esteroa (called $S$. californica in earlier publications), $\mathrm{LC}=$ Limonium californicum, $\mathrm{Sf}=$ Spartina foliosa, $\mathrm{Bm}=$ Batis maritima, Jc=Jaumea carnosa, $\mathrm{MI}=$ Monanthochloe littoralis, Ds=Distichlis spicata, $\mathrm{TC}=$ Triglochin maritima.

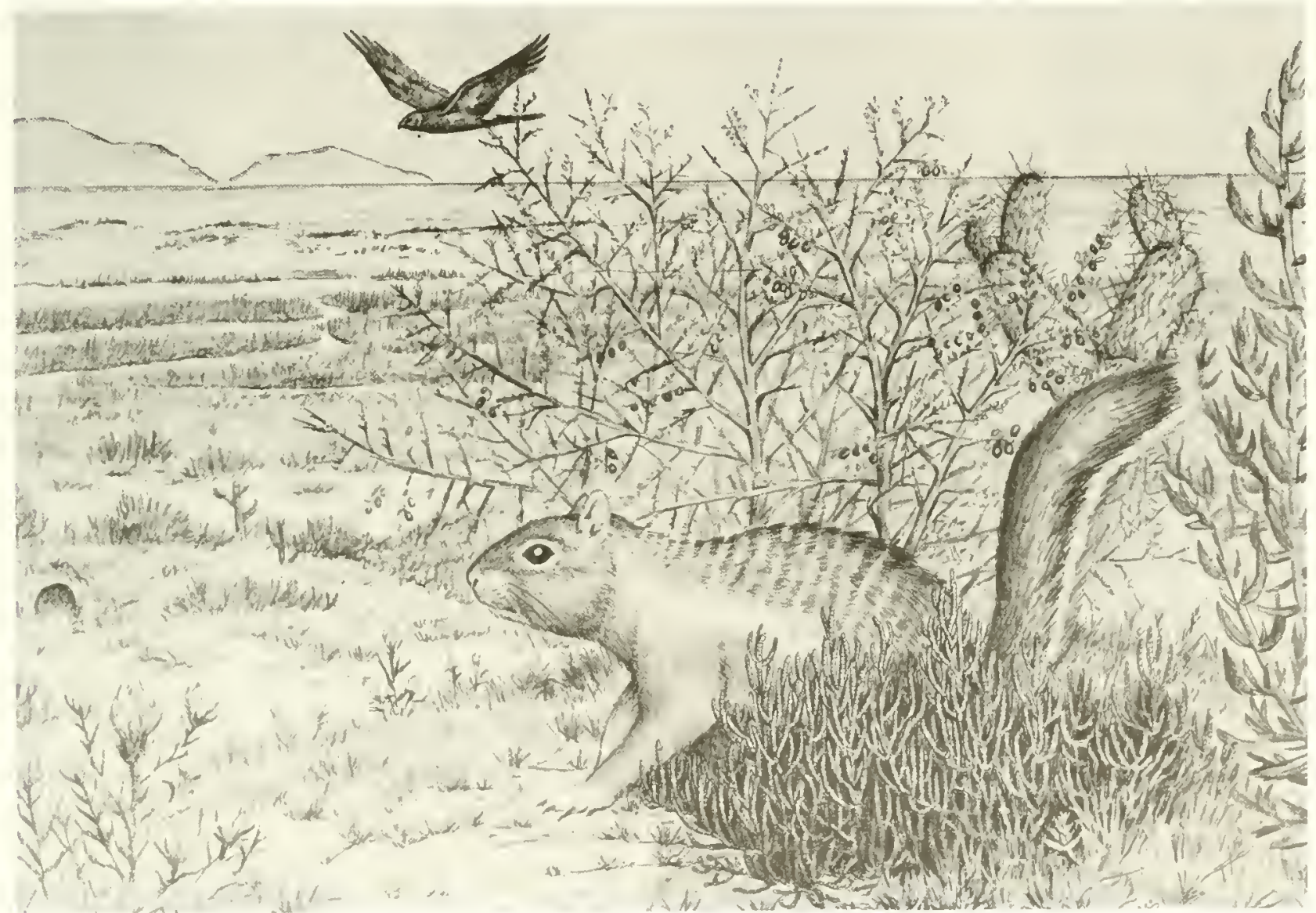

Figure 3.3. The upper marsh habitat with the California ground squirrel, salt marsh bird's beak (lower left), boxthorn, prickly pear, golden bush (far right), and glasswort and shore grass (in foreground). A northern harrier flies overhead. McIntire collection, (C) 1986 by Zedler. 
mouse, deer mouse, and house mouse (Mus musculus) were all trapped in areas with glasswort and pickleweed present, especially around salt pannes. The highest densities were recorded in spring (up to $75 / \mathrm{ha}$ ). Deer mice were dominant, with $59 \%$ of the captures. Western harvest mice comprised $31 \%$, and the remainder were house mice.

The higher salt marsh (Figure 3.3 ) is one of the most complex wetland communities, because it is subject to alternating environmental extremes of drought and inundation, because disturbance is frequent, and because its topography is sometimes mounded. Eighty-six mounds that ranged from 9 to $57 \mathrm{~cm}$ in height and 5.6 to $18.6 \mathrm{~m}$ in diameter were characterized in 1984 (Cox and Zedler 1986). Each "island" of higher topography allows species of the higher marsh to extend farther into the wetland. The marsh periphery is thus patchy and diverse; the larger the mound, the longer the plant species list. In addition, the mounds provide habitat for several herbivorous mammals, which in turn influence mound and intermound vegetation.

Cox attributes the mound formation to ground squirrels and other burrowing mammals that use the high ground. He suggests that over centuries, they gradually transport soils toward a central burrow opening until a pattern of mounds and intermound areas is created. Whether the concentration of squirrels on mounds is cause or effect, however, is hard to demonstrate in short-term studies. What is clear is that the mounds of high ground, which are surrounded by wetter marsh, add small-scale habitat diversity to the wetland. Where adjacent areas have been filled or developed, these islands provide the only clue to the higherelevation communities that might have occurred in the transition zone. The invasion process can be seen in wet winters, such as 1983, when high spots are leached of their salts and upland weeds (e.g., the wild radish, Raphanus sativum) germinate and grow. Such salt-intolerant species rarely persist beyond the next dry season.

Herpetofauna are likewise limited to these areas of high ground. The San Diego horned lizard (Phrynosoma coronatum blainvillei; Figure 3.4 ) is declining because of frequent collection, but a few remain in isolated areas. Snakes are not common, and their rarity partly explains the abundance of rodents such as ground squirrels (Spermophilus beechyii) and rabbits (Lepus californicus and Sylvilagus audubonii sactidiegi) that populate the upper marsh.

Birds that feed and/or nest in the high marsh include the white-crowned sparrow (Zonotrichia leucophrys), song sparrow (Melospiza melodia), western meadowlark (Sturnella neglecta), and killdeer (Charadrius vociferus). Other birds use the area extensively for foraging. Raplors, such as the northern harrier (Circus cyaneus), American kestrel (Falco sparverius), and golden eagle (Aquila chrysaetos), exploit the populations of small mammals; while Belding's Savannah sparrows, horned larks (Eremophila alpestris), and loggerhead shrikes (Lanius ludovicianus) feed on insects and other small prey (A. White, SDSU, pers. comm.).

The vegetation and soils of the upper marsh support many insects, spiders, and mites, but few other invertebrates (Figure 3.5). Tachys corax, literally the swift raven,

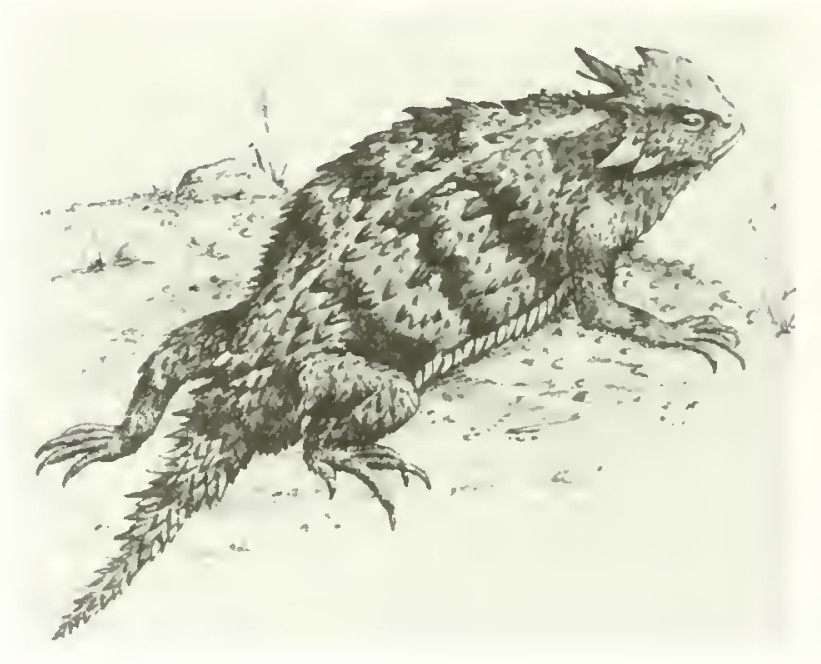

Figure 3.4. The San Diego horned lizard. Mclntire collection, (c) 1986 by Zedler. 
is the most prevalent species of carabid beetle found at Tijuana Estuary. This small insect (to $3.5 \mathrm{~mm}$ ) occurs in all marsh habitats and feeds primarily on other small arthropods. Another beetle, Eurynephala maritima, is found on the stems of pickleweed. Two spiders that inhabit this zone are Tetragnatha laboriosa and Pardosa ramulosa. The former is often found extended along the narrow leaves of cordgrass, while the latter is abundant on algal mats.

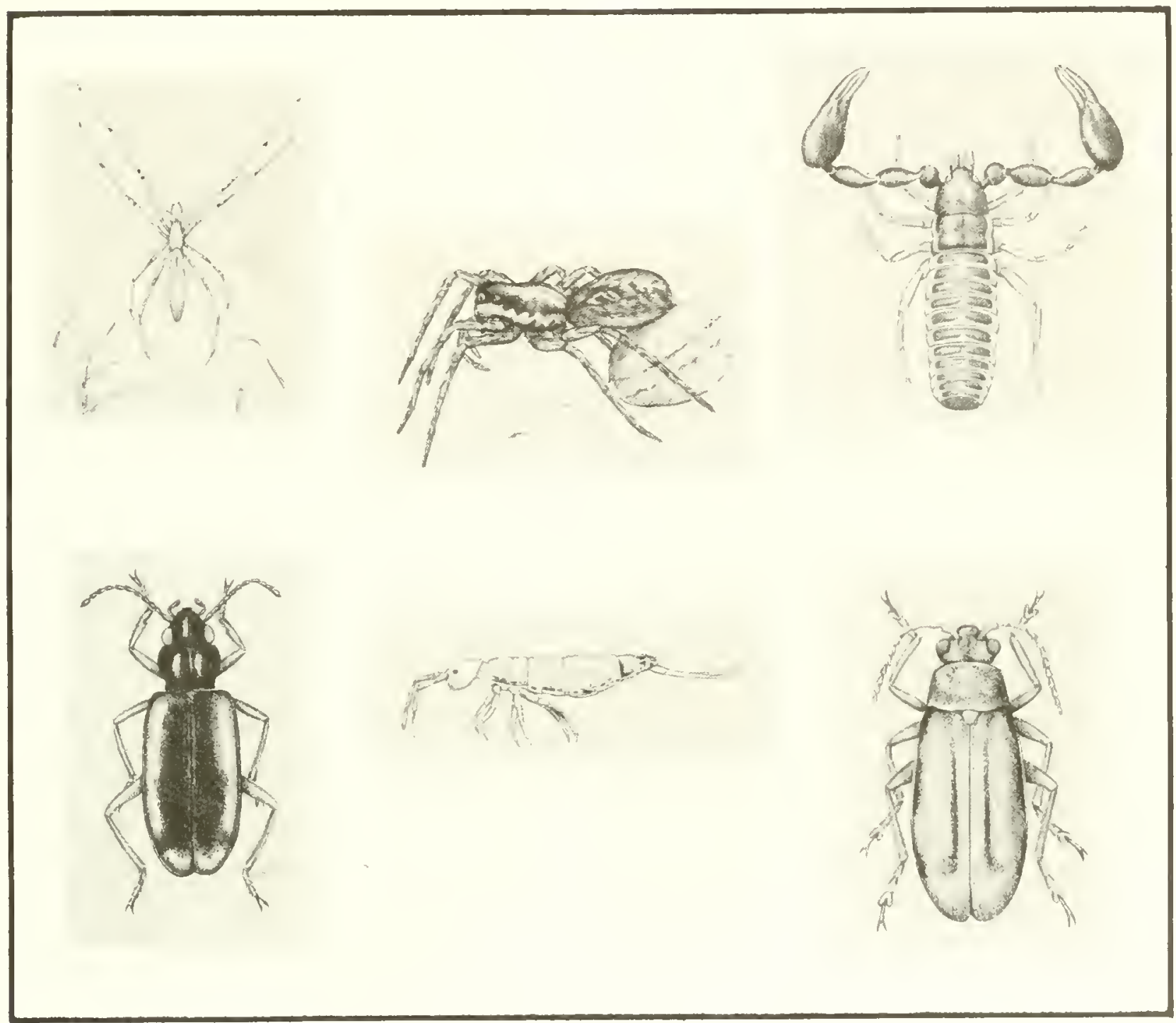

Figure 3.5. Selected insects and arachnids of the salt marsh. Illustrated are two spiders, Tetragnatha laboriosa (upper left, body $10 \mathrm{~mm}$ long) and Pardosa ramulosa (body $10 \mathrm{~mm}$ long; shown with eggs); the pseudoscorpion (Halobisium occidentale; Chelonethida), which is found with pickleweed; the springtail (Collembola: Isotomidae, Isotoma sp.; bottom center), a very small but abundant species, especially in plant detritus; and two beetles, Tachys corax (lower left) and Eurynephala maritima (lower right, body $6 \mathrm{~mm}$ long). Mclntire collection, (c) 1986 by Zedler. 
Characteristic plants of the higher marsh are the perennial glasswort (Salicornia subterminalis), shoregrass (Monanthochloe littoralis), alkali heath, sea lavender, and Atriplex watsonii. All of these species are perennials that reproduce vegetatively. Only during the rainy spring of 1983 was there conspicuous seedling establishment.

The endangered salt marsh bird's beak (Cordylanthus maritimus ssp. maritimus; Figure 3.3) occurs in the higher marsh. Because it is an annual, it is evident only for a short time during the spring and summer growing season, and because the plants are small, it is easiest to spot when in bloom (April-June). This annual plant apparently survives the warm dry summer by being hemiparasitic. Its roots develop haustoria that penetrate a variety of other species to gain water and nutrients. Subpopulations of bird's beak sometimes disappear for a year or more. Openings in the canopy allow seedling establishment (Vanderweir 1983, Fink and Zedler 1989), and the digging activities of small mammals may be an important part of the plant's ecology. However, too much disturbance (e.g., repeated trampling) destroys its habitat. Requirements of this endangered plant are discussed more fully in Section 3.9.1.

Intermediate elevations of the salt marsh are much more frequently wetted by the tides. Higher inundation tolerance is required of both the plants and infauna. The dominant plant is the perennial pickleweed (Salicornla virginica; Figure 3.6), which has the

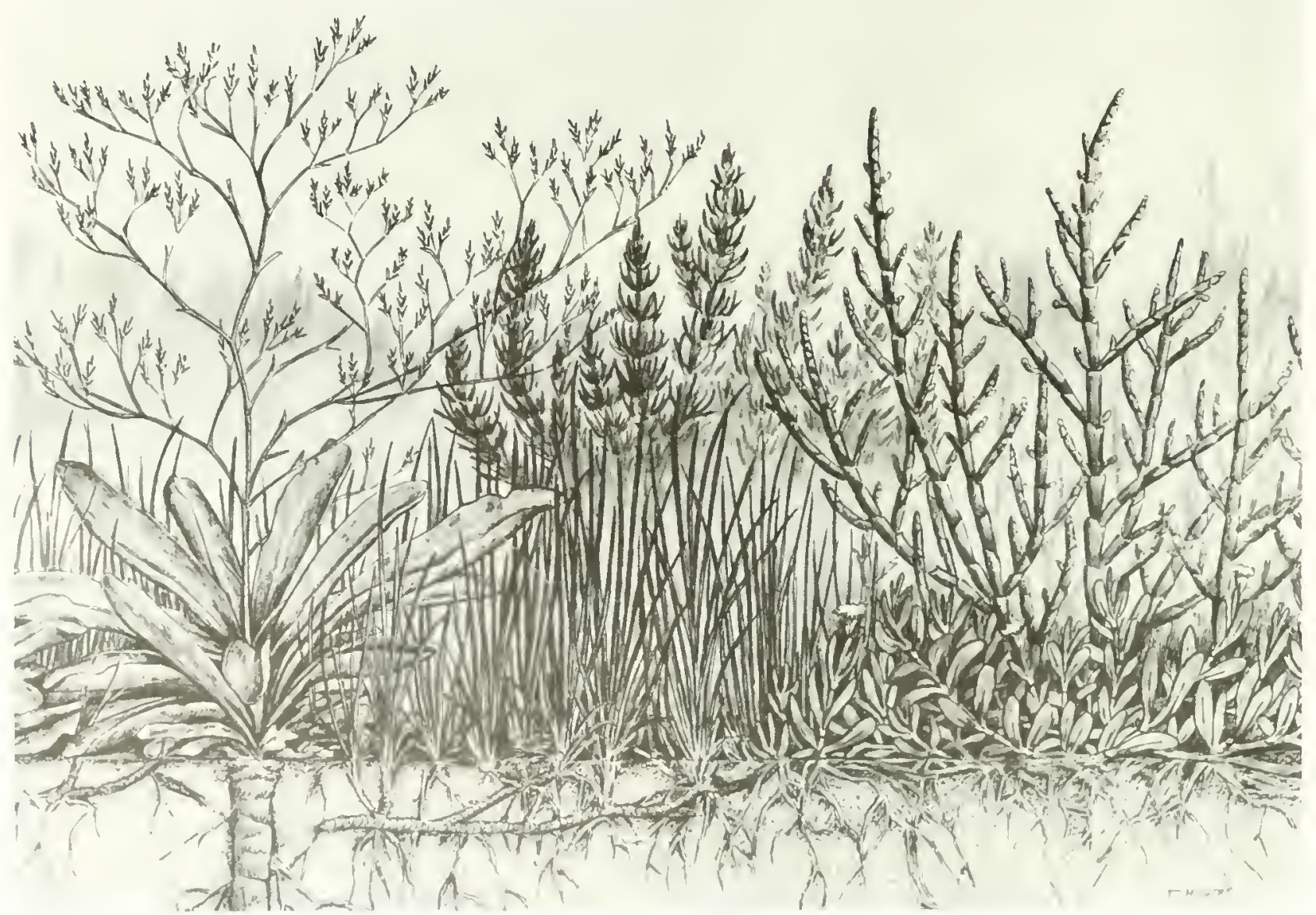

Figure 3.6. Vegetation of the mid-elevation marsh with sea lavender (left), arrow grass (foreground), sea-blite (background), perennial pickleweed (right), and Jaumea (lower right, in flower). Mclntire collection, (c) 1986 by Zedler. 
broadest elevational range of all the salt marsh species. It is also a species of broad geographic range, occurring on the Pacific Coast from Puget Sound, Washington, to the southern tip of Baja California, Mexico (Macdonald and Barbour 1974), and on the Atlantic Coast.

A small but significant bird finds its preferred habitat within pickleweeddominated marshes. Belding's Savannah sparrow (Figure 3.7) is listed by the State of California as an endangered species. It builds its nest low to the ground, often under a pickleweed canopy but sometimes in saltgrass (Distichlis spicata) or shoregrass. The birds perch on the taller plants and defend territories throughout most of the summer. They eat insects in the marsh, but often fly to creek or channel banks or even to the beach to feed (B. Massey, pers. comm.; and A. White, pers. comm.) Studies of their behavior, responses to disturbance, and habitat preferences have been conducted by White (1986). Interannual variations in population sizes of the Belding's Savannah sparrow are considered in the final section of this chapter.

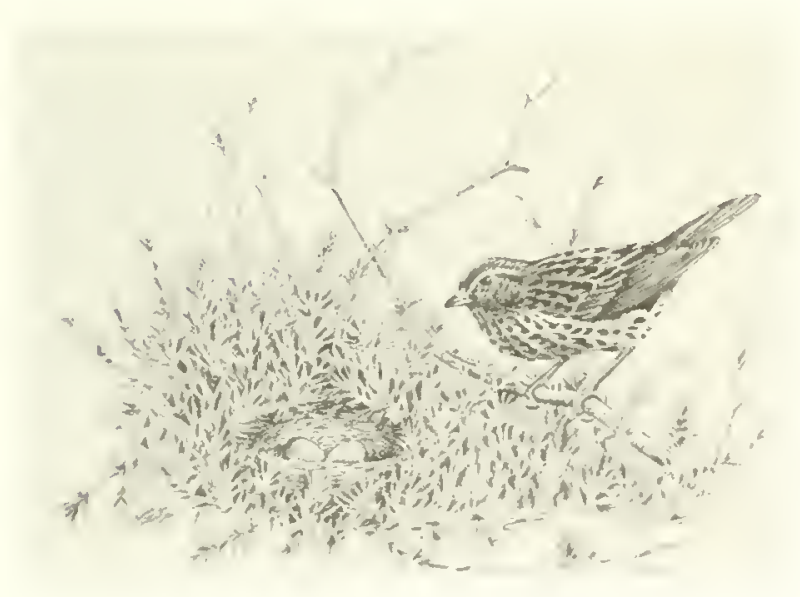

Figure 3.7. Belding's Savannah sparrow with ground nest in shore grass. Mclntire collection, (c) 1986 by Zedler.
Although pickleweed forms monotypic canopies in many of the region's lagoonal wetlands, i.e., those that close to tidal flushing on a fairly regular basis, it is usually mixed with several other succulents at Tijuana Estuary. Before 1984, arrow-grass (Triglochin concinnum) and sea-blite (Suaeda esteroa) were common cohabitants, and saltwort (Batis maritima) and annual pickleweed (Salicornia bigelovii) dominated areas that were poorly drained. The latter two species were most abundant around intertidal pools of the middle marsh (Table 3.2, Figure 3.8). Composition in this part of the marsh has changed greatly since 1980 (Chapter 5).

The animals of the midmarsh elevations are abundant and rich in species. Part of the reason is dependable moisture, and part is the availability of food. Algae are everywhere, in pools and under the salt marsh canopy (Zedler 1980, 1982a). In winter, filamentous green algae dominate the epibenthos, and in summer, filamentous blue-greens form dense tufted mats over the soil and plant stem bases (Figure 3.9). Over 70 species of diatoms occur within these filamentous mats (Table 3.3, Zedler 1982a).

The animals that utilize these foods include Ephydrid flies, whose larvae occur on decaying plant matter; California horn snails (Cerithidea californica); amphipods; and snails (Assiminea and Melampus, Figure 3.9). High concentrations of insects, especially water boatmen (Trichocorixia spp.), occur in the pools. They feed on the algae and in turn provide food for the California killifish (Fundulus parvipinnis), which spawn and develop in these pools (Fritz 1975).

A variety of birds forage in the midmarsh habitat. Common are the willet (Catoptrophorus semipalmatus), marbled godwit (Limosa fedoa), long-billed curlew (Numenius americanus), great blue heron (Ardea herodias), common egret (Casmerodius albus), and Belding's Savannah sparrow.

The lower marsh of Tijuana Estuary is the most well-studied habitat of the entire system. The dominant plant, Pacific cordgrass 
Table 3.3 The 38 most frequently encountered algae of the Tijuana Estuary salt marsh, listed in order of abundance within each catagory (Zedler 1982a). Ni = Nitzschia; $\mathrm{Na}=$ Navicula

\section{Green Algąe}

Rhizoclonium riparium

Enteromorpha clathrata

Blue-green algae

Microcoleus lyngbyaceus

Schizothrix mexicana,

S. arenaria, S. calcicola

\section{Diatems}

Trachyneis aspera

Denticula subtilis

Nitzschia vermicularis

Diploneis smithii
Ni. incrustans

Navicula ramosissima

Achnanthes sp.

Mastogloia exigua

Ni. subtilis

Amphora turgida

Gyrosigma obliquum

Ni. obtusa

Surirella fastuosa

Diploneis interrupta

Na. mollis

Ni. longissima

Ni. punctata $v$. coarctata

Achnanthes sp.
Ni. fonticola

Achnanthes brevipes

Ni. fasciculata

Caloneis westii

Amphora exigua

Na. digito-radiata

Rhopalodia musculus

Ni. angularis

Amphora coffaeformis

Pinnularia ambigua

Ni. obtusa v. scapelliformis

Diploneis bombus

Ni. acuminata

Diploneis lineata

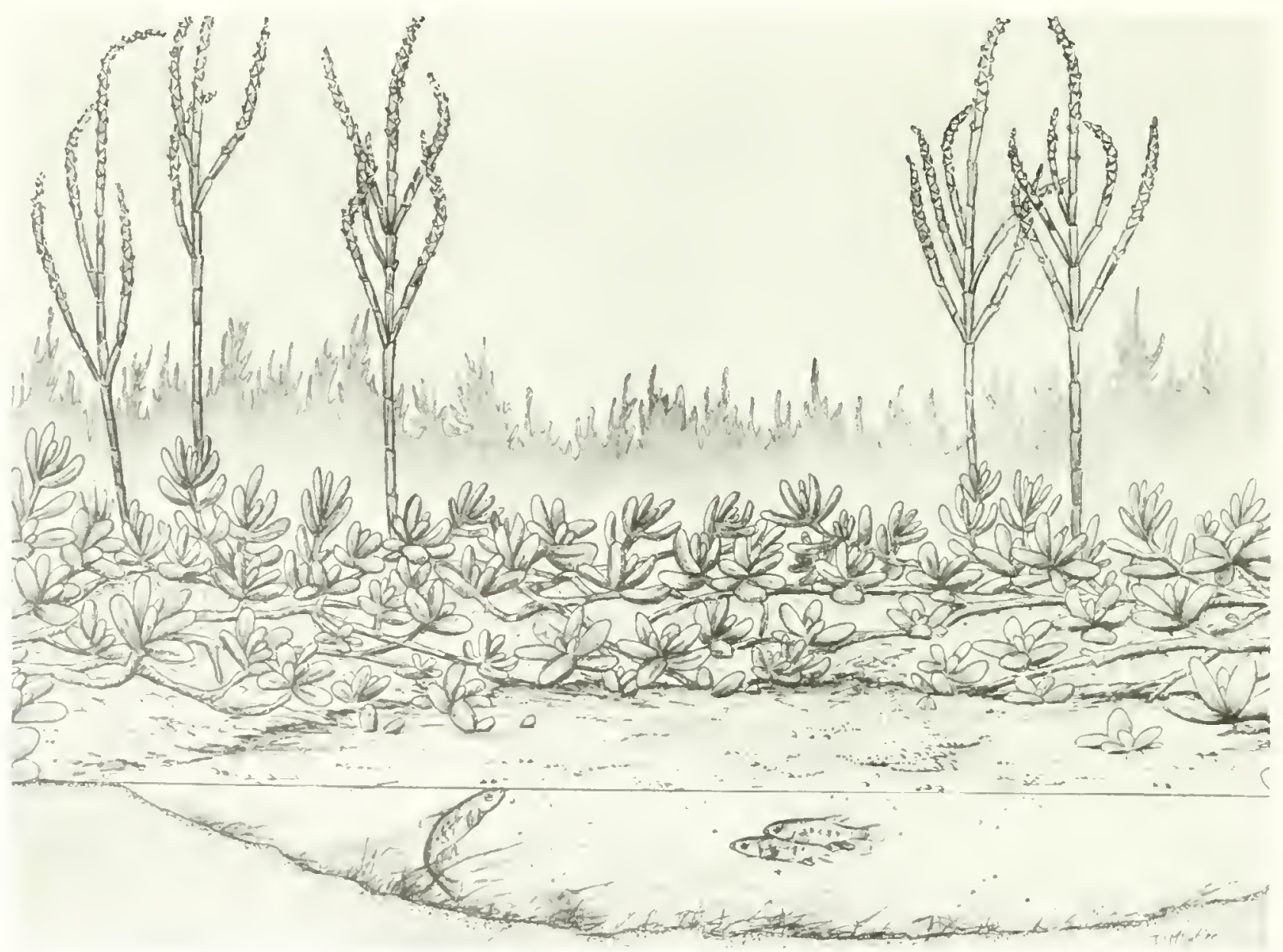

Figure 3.8. Intertidal pool with annual pickleweed (background) and saltwort (surrounding the pool). Mclntire collection, (c) 1986 by Zedler. 

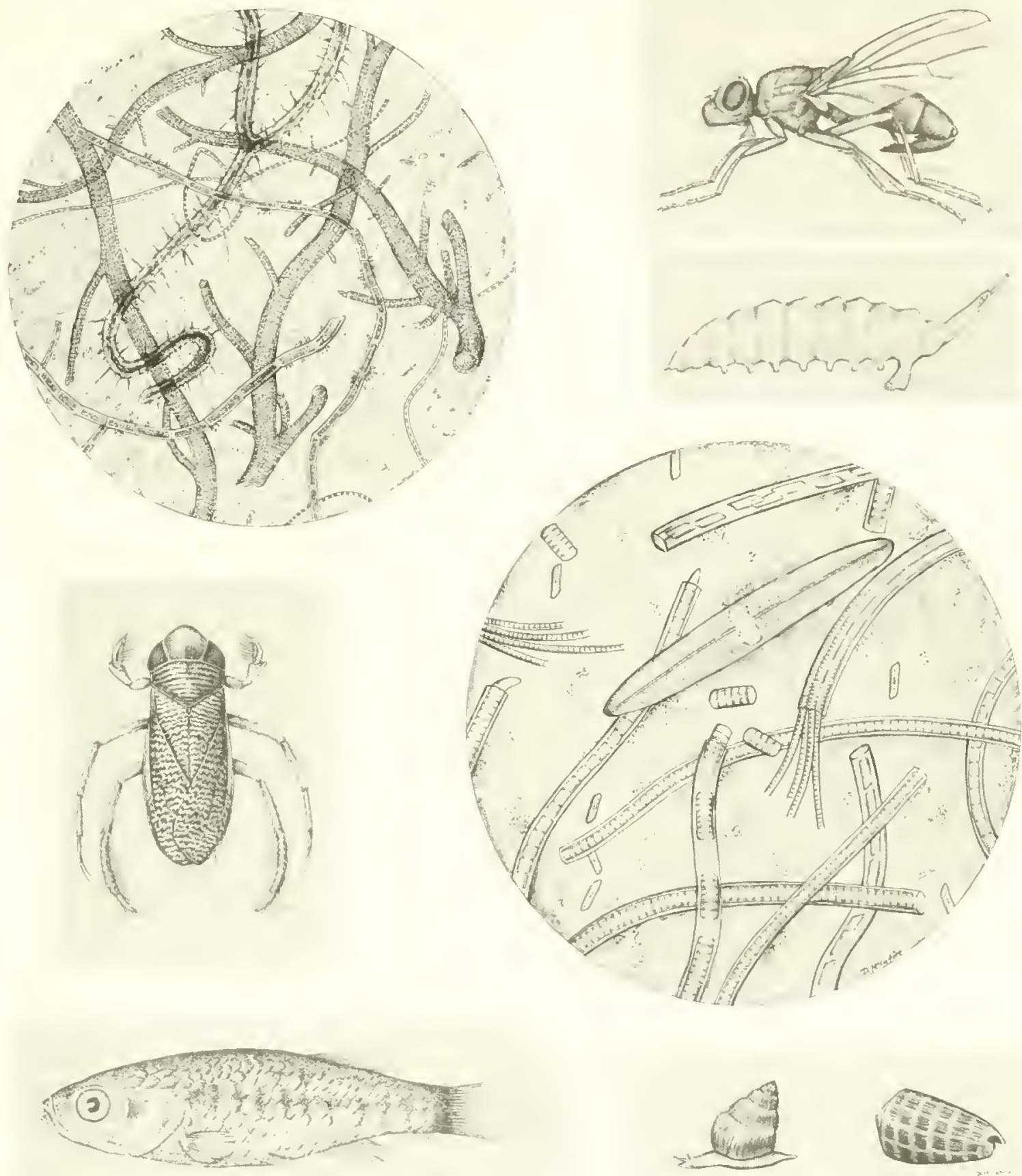

Figure 3.9. Algae of the tidal pools include the greens (Enteromorpha sp., and Rhizoclonium sp.; upper left), blue-greens (Microcoleus lyngbyaceus and Schizothrix spp.) and diatoms (Gyrosigma obliquum, Trachyneis aspera; lower right). These are fed upon by small molluscs (Assiminea and Melampus; lower right). Adult flies (Ephydra, Ephydridae; upper right) and their larvae feed on algae. The water boatman (Trichocorixia reticulata, left middle) can be dense in pools. The California killifish (lower left) feeds on arthropods. Mcintire collection, (c) 1986 by Zedler. 
(Spartina foliosa), typifies this community (Figure 3.10). Cordgrass has proven easy to monitor (Zedler 1983b), amenable to transplantation (Zedler 1984a), and responsive to manipulative experimentation (Covin 1984). Still, our knowledge of the total community is incomplete. Insects that live in and on the cordgrass are just beginning to be studied (Figure 3.11; Covin 1986). With new investigations, species that are now to science are discovered (e.g., Incertella sp. and Cricotopus sp., Figure 3.11). Both of these tiny insects have larvae that live within the leaves of cordgrass (J. Covin, SDSU, pers. comm.). Horn snails, lined shore crabs (Pachygrapsus crassipes), and yellow shore crabs (Hemigrapsus oregonensis) are abundant, but their habits are not well known. They feed on the algal mats and detritus and are themselves eaten by the larger marsh birds.

No animal characterizes the lower marsh better than the light-footed clapper rail (Figure 3.12; Jorgensen 1975; Zembal and Massey 1981a,b; Massey ot al. 1984, Zembal 1990, Zembal 1991). Jorgensen's (1975) study at Tijuana Estuary assessed the birds' occupancy, nesting, and foraging in five habitat types (high marsh, middle marsh, saltwort-annual pickleweed, short cordgrass, and tall cordgrass).

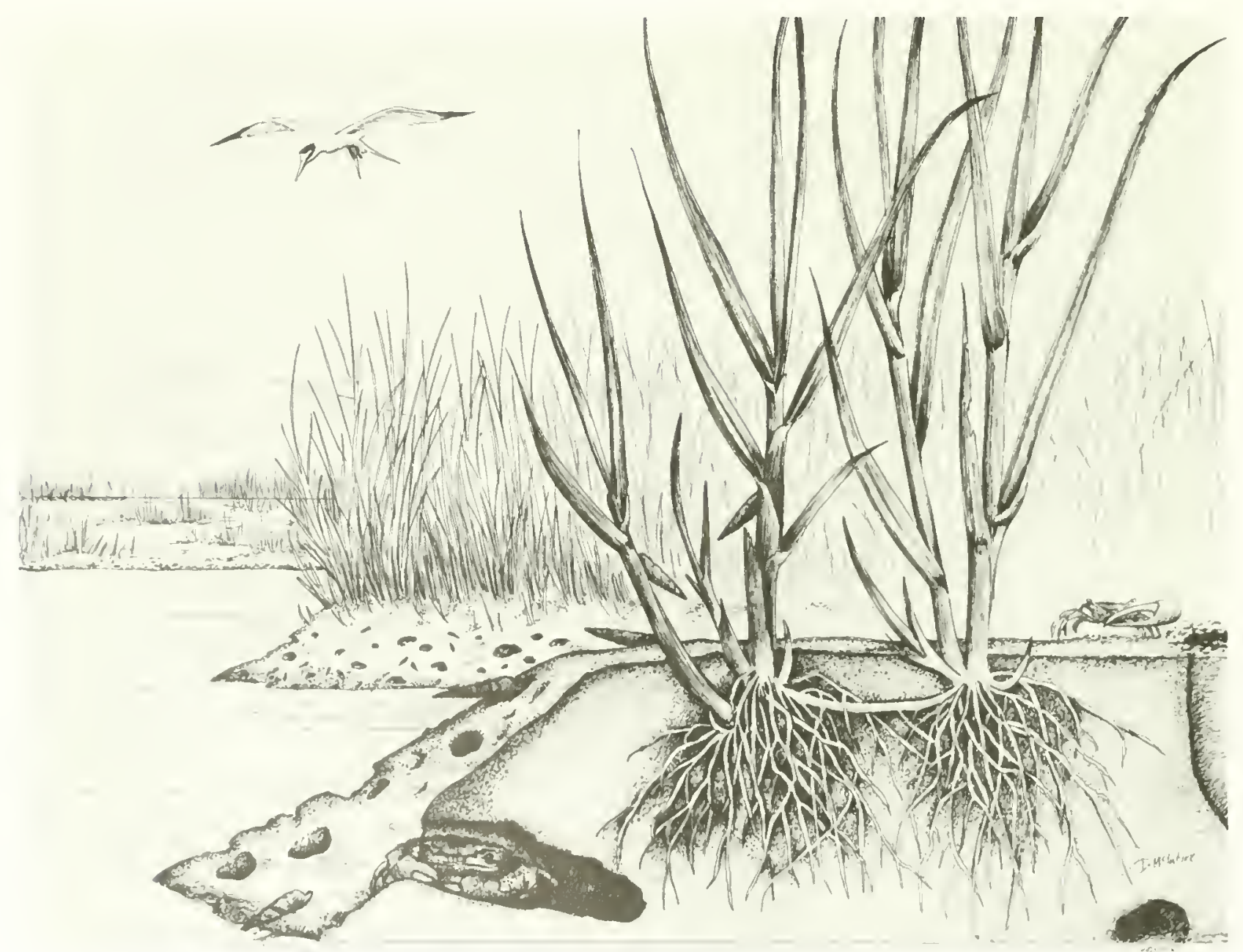

Figure 3.10. The cordgrass community, showing the fiddler crab (right) and the lined shore crab (in burrow). California horn snails are attached to the cordgrass stems and on the mud. A California least tern is poised, ready to dive for fish in the channel. Mclntire collection, (C) 1986 by Zedler. 

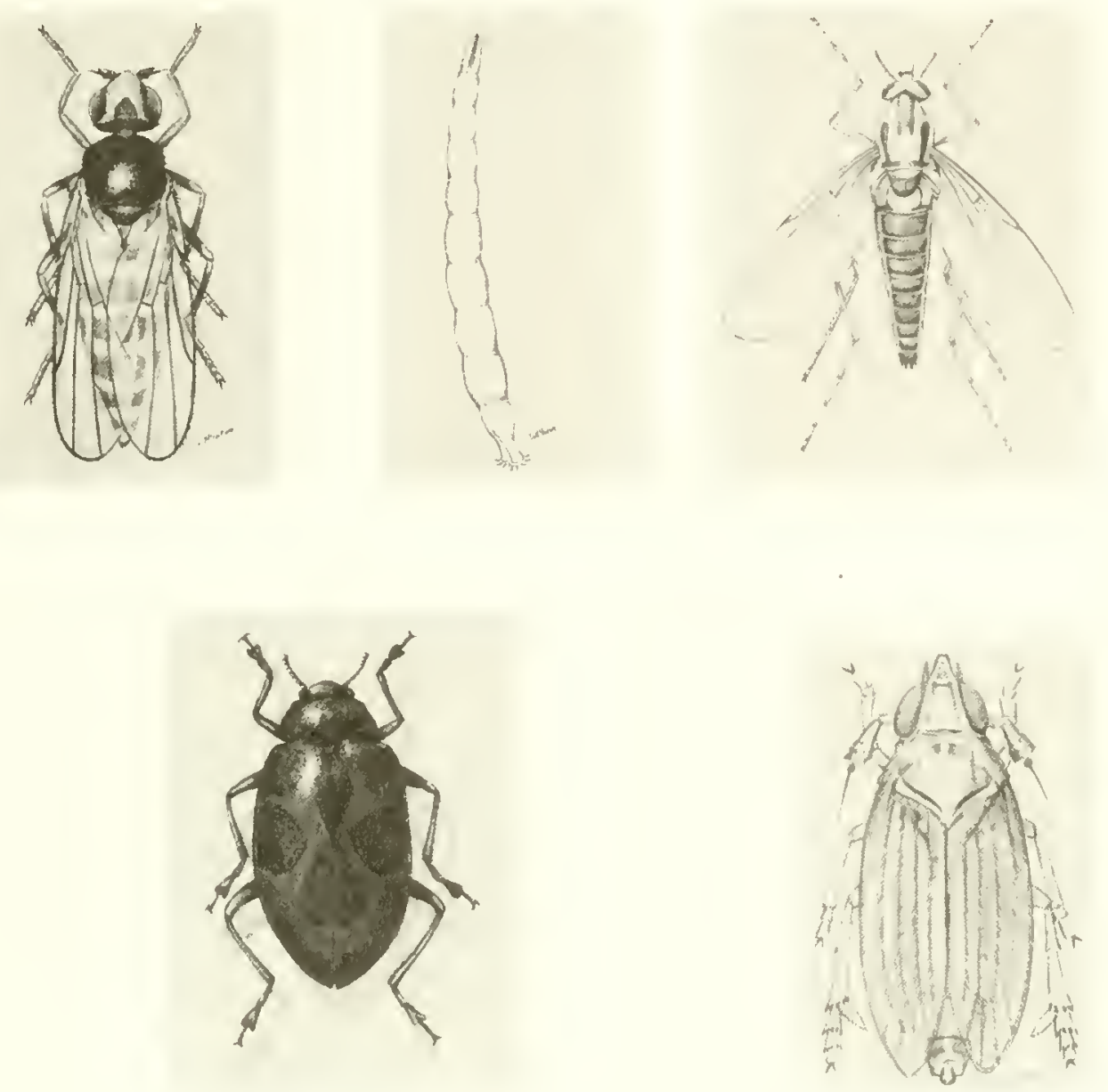

Figure 3.11. Insects of the cordgrass community. Two tiny dipterans, Incertella sp. (Chloropidae) and Cricotopus (Hydrobaeninae), have larvae that live in and feed on cordgrass stems; the beetle (Coleomegilla fuscilabris; Coleoptera; Coccinelidae) is abundant only on cordgrass; and the planthopper (Prokelisia; Homoptera: Delphacidae) is found on cordgrass in all the marshes of this region. Mclntire collection, (c) 1986 by Zedler.

Rails are censused in winter when tides exceeded $2.2 \mathrm{~m}$ (7.3 ft) MLLW and in summer using taped vocalizations. Thirty-four breeding pairs were identified in 1974, of which 18 were in tall cordgrass, 11 in middle marsh, 4 in short cordgrass, and 1 in high marsh. Nesting density (number per area of habitat type) was greatest (about 3/ha or $1.3 /$ acre) in tall cordgrass. The average elevation at which nests occurred was $1.6 \mathrm{~m}$
(5.1 ft) MLLW, which corresponded to the mean daily higher high tide (MHHW). The highest density of nests was observed in the northern arm of the estuary, where the single highest winter census count was 55 individuals. In comparison, a maximum of nine birds was counted in the area near the mouth of the estuary, and at most four in the southern arm of the estuary, where cordgrass 
is absent. Recent population dynamics are presented in Section 3.9.2.

Jorgensen (1975) suggested several advantages of cordgrass-dominated marshes for the rails. The tall grass provides cover for protection against predators and the birds weave a canopy of live stems over their nests (Figure 3.12). Both the egg and brood nests are woven of dead cordgrass stems. The nests that are anchored to vertical cordgrass stems can float, thereby preventing submergence; the nests in cordgrass can be more firmly anchored than elsewhere; the lower marsh areas are wetter and less accessible 10 terrestrial predators, and the black-colored chicks are camouflaged against the black substrate of the lower marsh. Finally, their most common foods occur in or near areas where cordgrass is abundant. Yellow shore crabs and lined shore crabs were the dominant items in regurgitated pellets analyzed by Jorgensen (1975). Further evidence of the species' relationship with tidal cordgrass marshes developed in 1984 when cordgrass died and the Tijuana Estuary population of rails dropped to zero (Chapter 5).

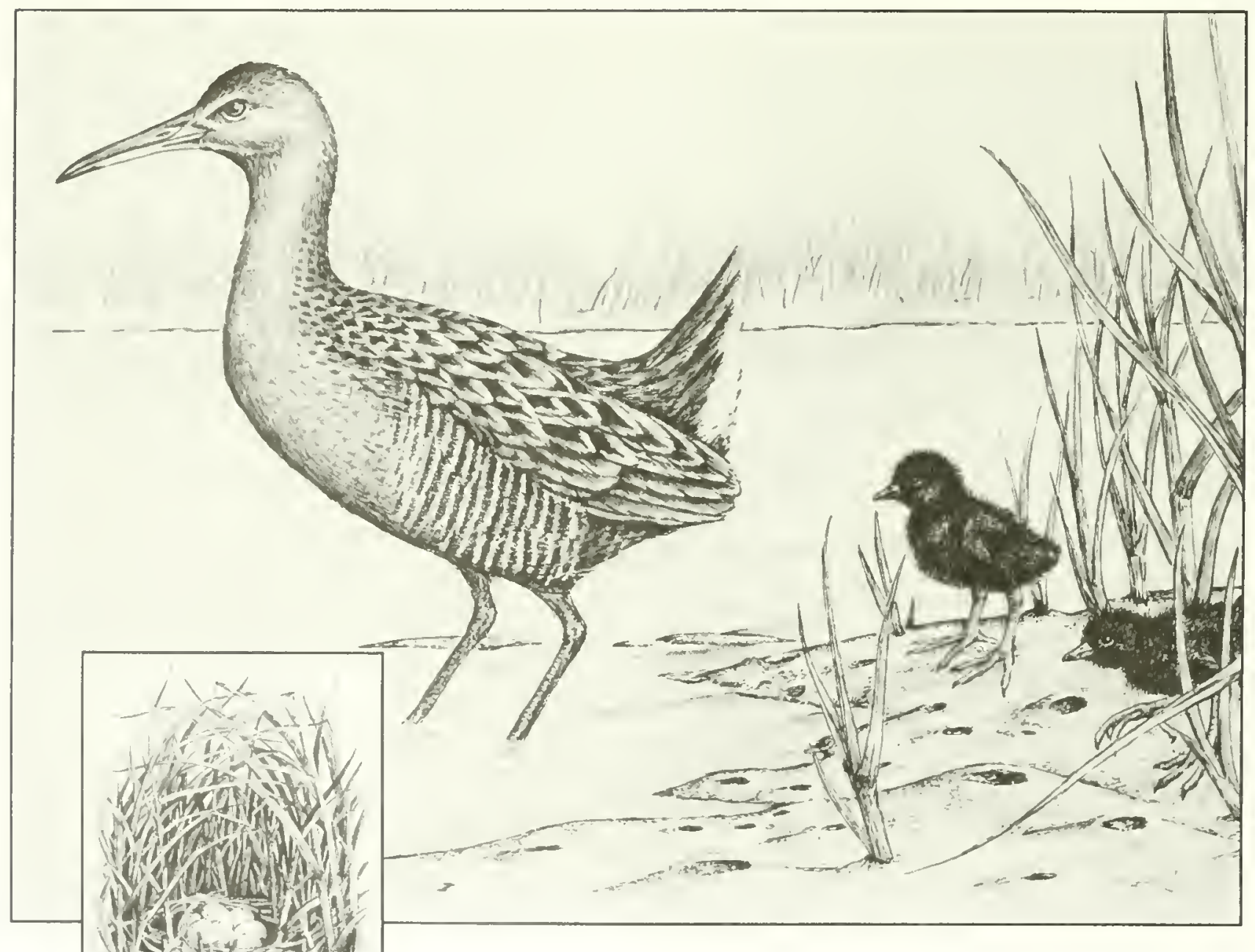

Figure 3.12. The light-footed clapper rail finds cover, food, and nesting material in the cordgrass marsh. Its nest is a masterpiece of construction, with a floating platform and protective arch, commonly made of cordgrass. Mclntire collection, (C) 1986 by Zedler. 


\subsection{SALT PANNES}

The salt pannes are upper intertidal areas that are devoid of vegetation. They accumulate winter rainfall and saline water from high spring tides in December through February; in summer, they are covered by a salt crust that forms with evaporation of salt spray and tidal water from high spring tides in May through July. Soil salinities of $200 \mathrm{ppt}$ are common at the end of the dry season. Two contrasting communities can thus be found (Figure 3.13). During the winter aquatic phase, algae flourish and aquatic insects become abundant. Ducks utilize the shallow waters for feeding and resting. During the summer dry season, the habitat appears barren, because most of the resident insects and other arthropods live in the soil.
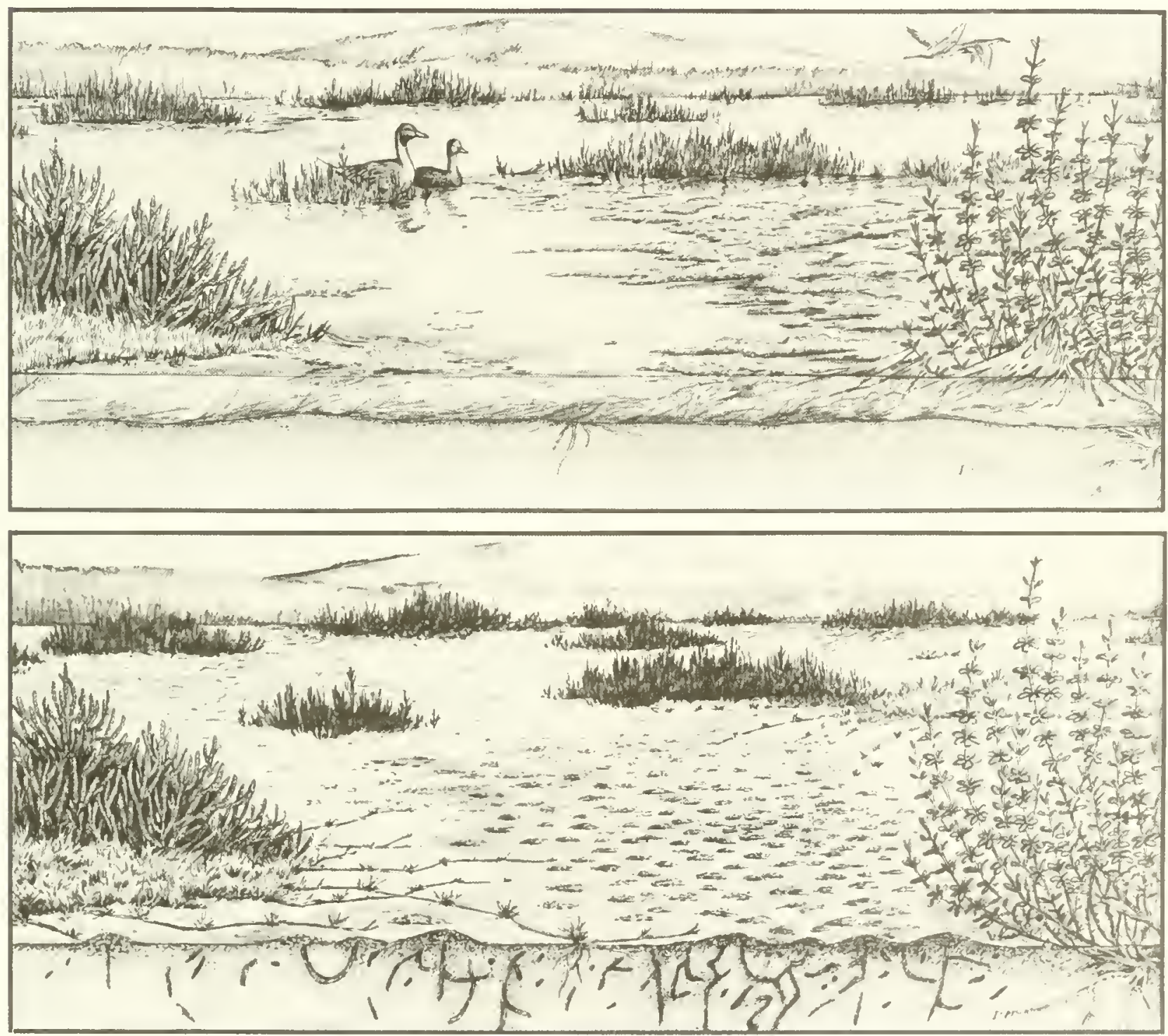

Figure 3.13. During winter (top) the salt pannes trap rainfall and tidal water; during summer (below) they dry and are covered by a white sall crust. Algae and ditch grass (Ruppia maritima) grow during the aquatic phase; pintails and other aquatic birds feed and rest there. In summer, abundant burrows of a diverse insect community are visible. Mclntire collection, (c) by Zedler. 
Because the dry season is longer than the winter inundation period, barren conditions prevail; hence, the habitat is called a salt panne, rather than a temporary tidal pond. The ephemeral nature of the aquatic phase makes it difficult to appreciate the productivity and complexity of these communities. It is often recommended in mitigation proposals that salt pannes be converted to some other use, because their wetland values are assumed to be low. Very little research has been done in salt pannes, so their habitat values have not been quantified.

Species that are characteristic of salt pannes have developed adaptations to the extremes of prolonged inundation and high salt accumulation. Many soil-dwelling insects utilize "plastrons," or air traps, that allow them to respire when the water or soil is anaerobic (Foster and Treherne 1976). In addition, many have developed waterproof integuments and mechanisms for secreting hypertonic rectal fluids to regulate osmotic and ionic balance.

Rove beetles (Staphylinidae, Genus Bledius; Figure 3.14) were studied at Tijuana Estuary by Nordby (1984). Several species of these small beetles inhabit complex underground labyrinths that are evidenced at the surface by excavated "middens." The density of middens reaches $500 / \mathrm{m}^{2}$; the tunnels beneath them are about $20 \mathrm{~cm}$ in depth. Densities of beetles were highest in March 1984, when 8 adults and 22 juveniles were recorded per $1,650 \mathrm{~cm}^{2}$ core. Reproduction occurred in the spring with eggs attached to the sides of burrows by means of a clear, threadlike material.

Intertidal elevation is the most important physical variable that characterizes rove beetle distribution patterns. They are densest in a narrow belt at about the high tide line. The beetles prefer soil dampened by tldal inundation but not covered by standing water. A typical biweekly fluctuation of midden densities occurs with the high summer tides: as a high tide recedes, midden mounds appear as the beetles begin to burrow, more densely at the region where the soils have begun to dry and less densely at the water's edge; as the soil dries, the middens accumulate as excavation activities continue; then, an ensuing hlgh tide erases the surface middens, and the pattem is repeated. It is not known where the beetles

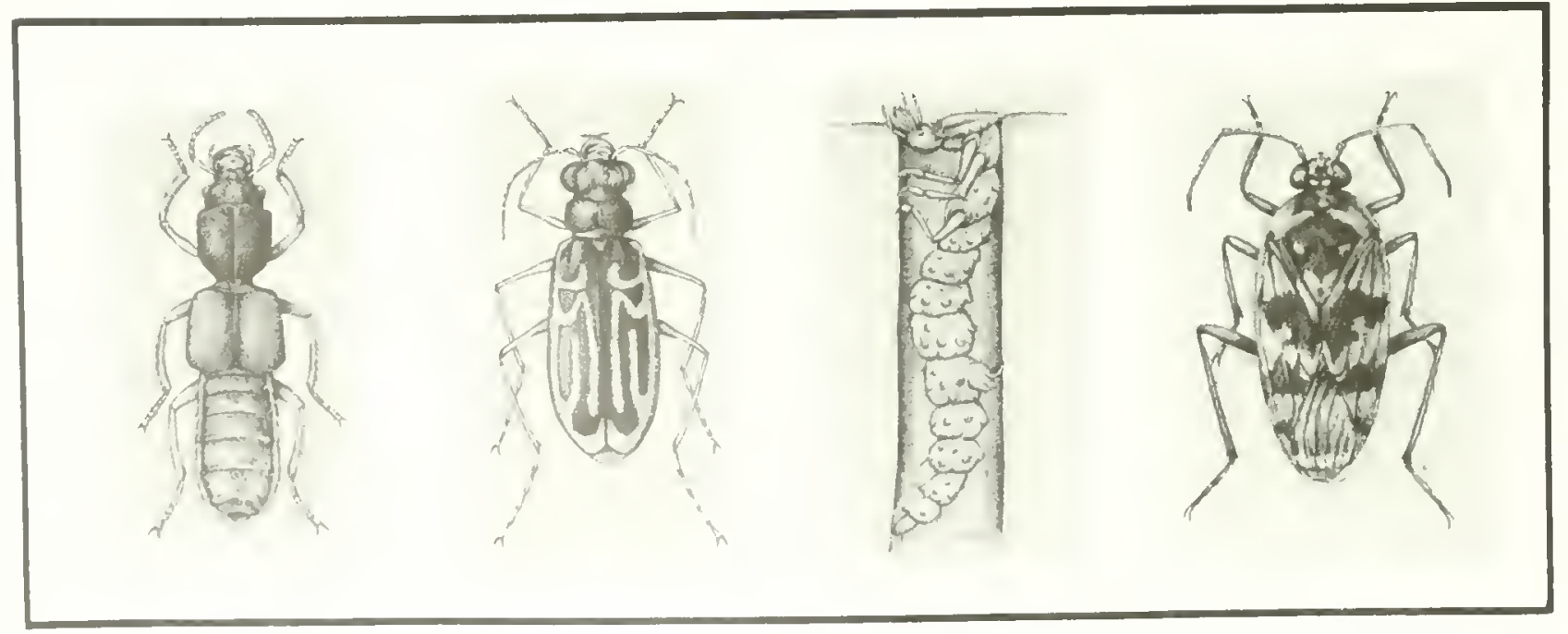

Figure 3.14. The salt panne insects include species of rove beelle (Bledius; Coleoplera: Staphylinidae, on left) and tiger beetle (at center: adult Cicindela gabbi and larva of C. oregona; Coleoptera: Cicindelidae). The saldid bug (Pentacora signoreti; Hemiptera: Saldidae, $8 \mathrm{~mm}$ long) is an important and widespread marsh predator. Mclntire collection, (c) 1986 by Zedler. 
are during high tide. In studies of a Scandinavian species of Bledius, Larson (1953) found that they evacuated tunnels during high tide and could be found beneath debris at the wrack line. This did not happen at Tijuana Estuary. Very few beelles were ever observed outside a burrow, regardless of tide.

Some insects that inhabit the salt pannes are considered "threatened." Threatened species are those whose range is declining due to loss of habitat and/or have been proposed as candidates for State or Federal listing. Among such insects are the tiger beetles (genus Cicindela). Tijuana Estuary supports the highest diversity and abundance of tiger beetles of any coastal locality in southern California and possibly all of California (C. Nagano, US FWS, pers. comm.). There are at least four species of this genus that occur here, two of which inhabit the salt pannes, although they have been observed there only in low numbers. These are the mudflat tiger beetle (Cicindela trifasciata sigmoidea) and Gabb's tiger beetle (C. gabbi, Figure 3.14).

Tiger beetles are predaceous; they feed upon any arthropods they can overpower. Adults are found on mud or sand near permanent bodies of water. Larvae inhabit burrows in the soil in the same area as the adults. The larvae (Figure 3.14) are also predaceous, using hooklike mandibles to capture and kill their prey, which is then consumed within the burrow. Because their prey includes insects that are harmful to man, these beetles are considered beneficial. Tiger beetles are preyed upon by other salt panne and tidal flat insects including robber flies (Diptera: Asilidae) and dragonflies (Odonata: Anisoptera), and numerous vertebrates such as birds, reptiles, and mammals (D. Mclntire, pers. comm.).

Tiger beetles are considered to be good indicators of the disturbance to coastal systems (Nagano 1982); the least disturbed habitats have several species of tiger beetles. Although quantitative data from the period before closure of the estuary mouth are lacking, qualitative estimates indicate that populations increased significantly after the mouth was reopened (Mclntire, San Diego naturalist, pers. comm.).

Another group of insects that can be regarded as good indicators of disturbance are the true bugs of the order Hemiptera, family Saldidae. Several taxa of these insects occur on the least disturbed salt pannes. They have a wide salinity tolerance and are carnivorous, feeding on springtails, mites, and other insects and spiders. One member of this family, Pentacora signoreli (Figure 3.14), is very abundant at Tijuana Estuary. Individuals coated with salt crust have been observed on salt pannes, but the mechanism for tolerating such high salinities is not known (Mclntire, pers. comm.).

Salt pannes are often used as foraging areas for Belding's Savannah sparrows, which feed on the insects there. California least terns and snowy plovers are both known to nest on salt pannes. The latter two species use preformed depressions, such as animal footprints, in the hardpan for nest scrapes. If there are patches of other substrate, such as sand or small wrack, the birds will create their own scrapes on these. When the pannes are inundated, snowy plovers also use them as feeding areas (White, pers. comm.).

\subsection{BRACKISH MARSH}

Habitats that typically have reduced water salinities (between 0.5 and $30 \mathrm{ppt}$ ) are considered brackish or mixohaline (Cowardin et al. 1979). In southern California, such habitats occur next to seepages or where rainfall or runoff is impounded. Evaporation then concentrates salts. Water levels flucluate widely but irregularly. Due to differences in salinity and water levels, the plants and animals of the salt marsh are generally not found here. Instead, a community more characteristic of the region's freshwater marshes is found (Figure 3.15). Cattails (Typha domingensis) and bulrushes (Scirpus californica) are the usual dominants among the emergent species, while the submergent ditchgrass (Ruppia maritima) is abundant seasonally. Red-winged blackbirds 


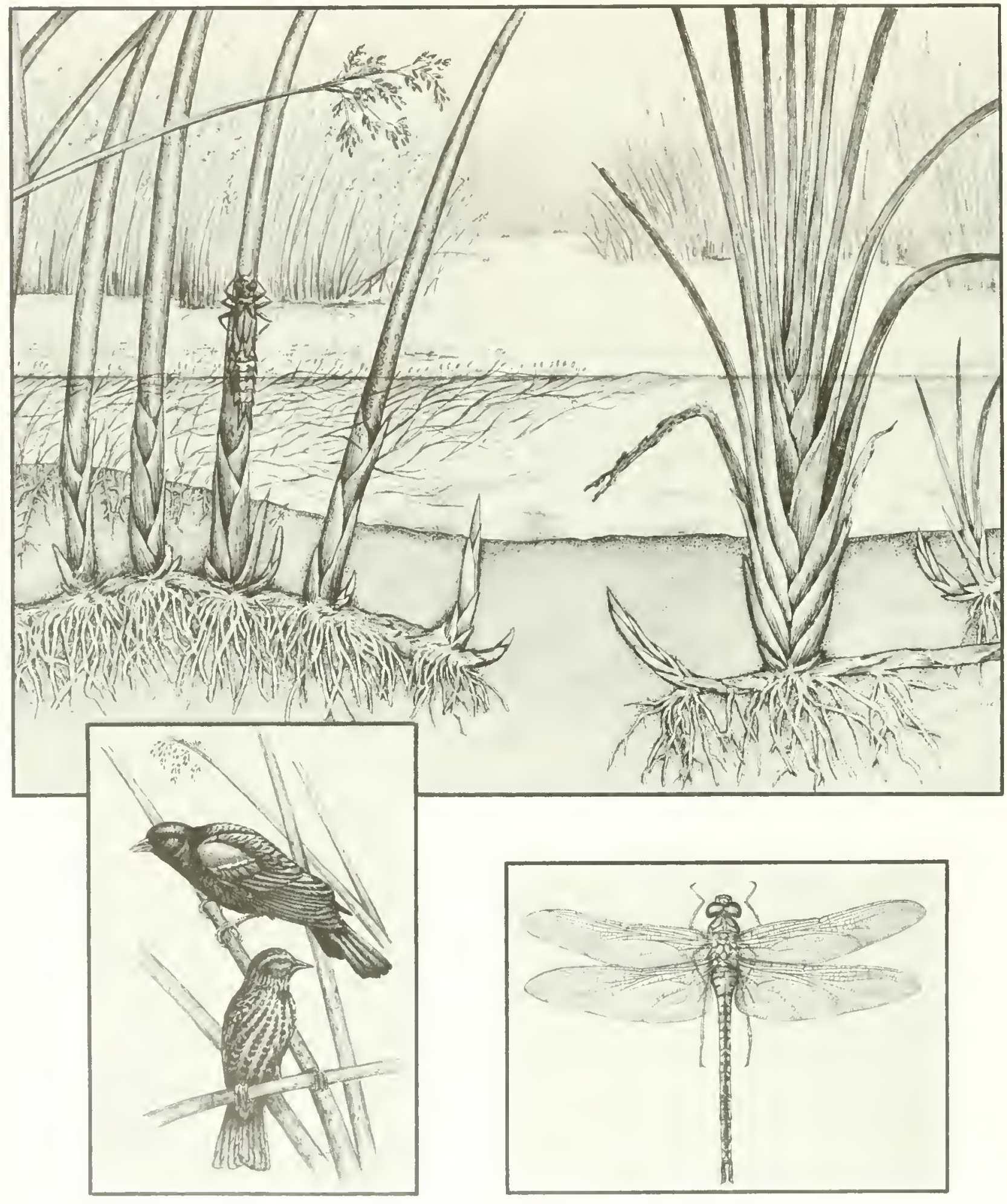

Figure 3.15. Brackish marsh habitats support large emergents, including bulrushes (Scirpus californicus) and cattails (Typha domingensis), as well as the submerged aquatic, ditch grass (Ruppia maritima). Dragonfly nymphs (on the bulrush stem) are adults, such as the green darner (Anax junius; Odonata: Aeschnidae) are common. Red-winged blackbirds are characteristic residents of the emergent brackish marsh. Mclntire collection, (C) 1986 by Zedler. 
(Agelaius phoeniceus) commonly set up territories in the tall, dense vegetation, and dragonflies (Odonata: Anisoptera; Figure 3.15) are obvious insect inhabitants.

At Tijuana Estuary, the areas of brackish marsh appear to have formed artificially following hydrologic and topographic modifications. The 1928 air photo (Figure 2.6) indicates that natural brackish marsh may have been present at the inland lagoon before a channel was dredged to make the area tidal. Before 1900, the area would have supported brackish marsh if sufficient rainwater accumulated or if seepages were present. In the absence of continual brackish or freshwater inputs, the depression would probably have been an alkali sink colonized by brackish species during wetter periods.

Brackish marshes are now found west of the airfield, at the abandoned gravel pits, where rainfall accumulates, and at the southern end of the estuary, where sewage spills from Mexico through Goat Canyon provide an intermittent water source. The braided channels of the Tijuana River support ephemeral patches of brackish marsh, but their location and longevity relate to recent flooding and to spills of sewage or irrigation water.

The function of these brackish habitats relative to the estuarine ecosystem is under debate. Further north, there is evidence that springs were frequent around the intertidal wetlands, and various restoration plans have called for the creation of large areas of freshto-brackish marshes (e.g., State Coastal Conservancy plans for Orange County wetlands and for restoration of Los Cerritos Wetland). Much of the presumed value of brackish marsh habitats comes from studies of Upper Newport Bay (Zembal and Massey 1981a), where the State's largest population of lightfooted clapper rails persists. Rails use both brackish and salt marsh habitats at Upper Newport Bay and at San Elijo Lagoon, and the nontidal brackish marshes are a likely refuge for the birds during high water. Thus, the proximity of several small brackish marshes along the periphery of saline marshes may improve conditions for rails. The causeeffect relationships need to be tested, not just for rails, but for the variety of brackish and saline marsh species. Furthermore, the reciprocal interactions, i.e., the use of saline marshes by brackish species, need to be investigated.

On at least one occasion, brackish marsh species expanded into the estuary under nontidal conditions. During the 1984 closure, red-winged blackbirds moved into the lower salt marsh and set up territories in the cordgrass. Their effect on native salt marsh birds (e.g., Belding's Savannah sparrows and clapper rails) was not assessed, but it should be before recommendations are made to add brackish marshes along the periphery of Tijuana Estuary salt marsh. Such experimental work would be possible if artificial fresh, brackish, and saline marshes were constructed at the Pacific Estuarine Research Laboratory (Chapter 6).

Fresh and brackish marshes may function as a general refuge for animals when the estuary has high water. It has been assumed that the Dairy Mart Road Ponds, about $5 \mathrm{~km}$ upstream of Tijuana Estuary, are used by estuarine birds, because many species are seen in both localities. These ponds occur in areas where gravel mining has left large pits; the water source is both river flow and ground water. Black-crowned night herons (Nycticorax nycticorax; Figure 3.16), black-necked stilts (Himantopus mexicanus), American avocets (Recurvirostra americana; Figure 3.17) and snowy egrets (Egretta thula) are conspicuous among these tree-lined ponds.

Boland's (1981) data on shorebirds in Tijuana Estuary support the concept that ponds provide alternative resting and feeding sites during high tides. He compared bird use in the intertidal flats with that of the river and the inundated salt pannes at the southern end of the estuary. Of the 21 shorebird species Boland studied at Tijuana Estuary, 10 used both the river and pool habitats for feeding (Table 3.4). Nearby, in the blocked channel (an area that was once tidal), different birds, including black-necked stilt, phalaropes, and willets were commonly found feeding Heavy use of these nontidal areas by waders, sandpipers, and plovers shows that estuarine shorebirds are not restricted to intertidal habitals. 


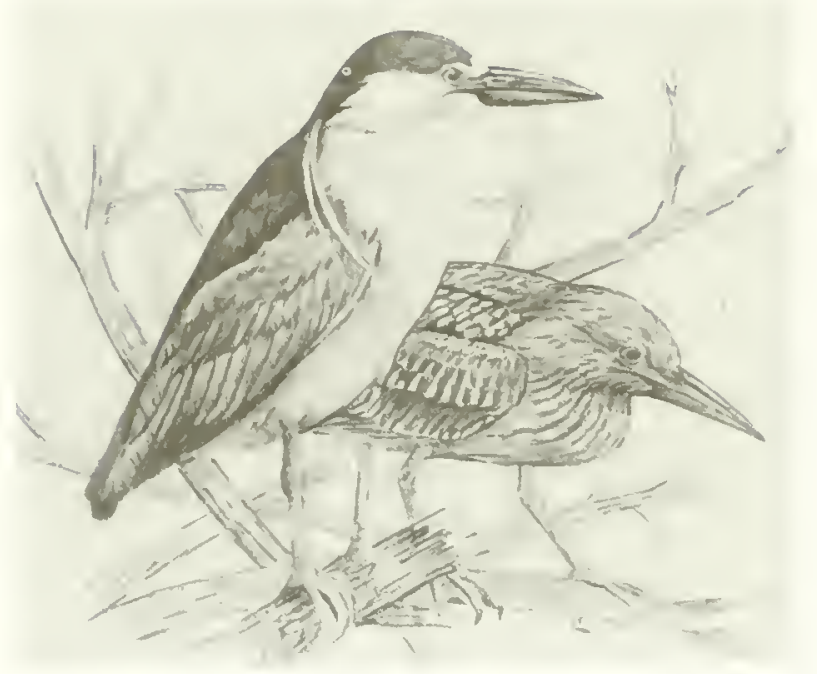

Figure 3.16. Black-crowned night herons. Juveniles (right) have streaked plumage. Mclntire collection, (c) 1986 by Zedler.

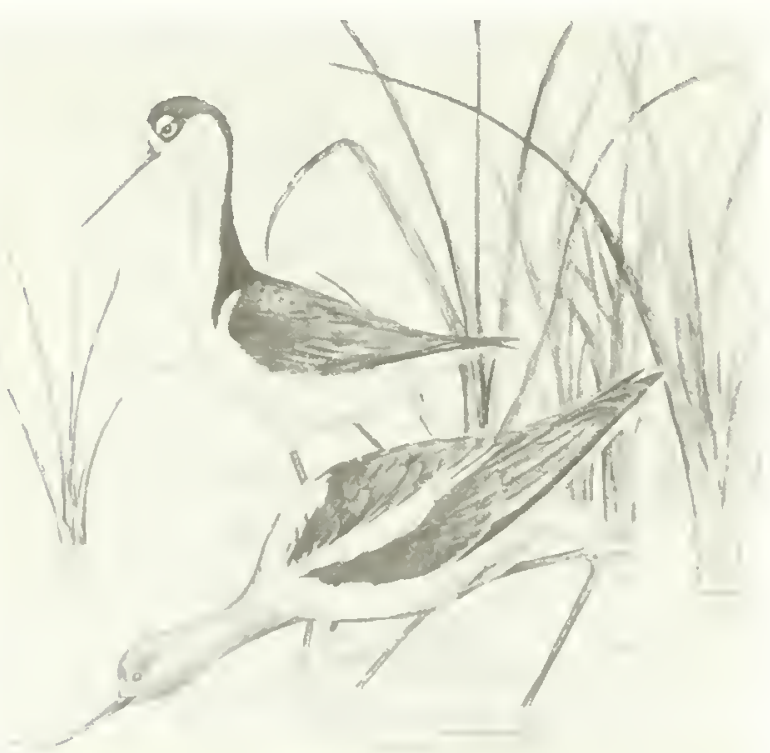

Figure 3.17. Black-necked stilts and American avocets (foreground) wade and feed in the open water of brackish habitats. Mclntire collection, (c) 1986 by Zedler.
Most of our understanding of how brackish marsh vegetation relates to saline conditions comes from studies at the San Diego River marsh (20 km north of Tijuana Estuary). There, 1980 floodflows were prolonged by reservoir discharge, and intertidal marsh soils were oligohaline (under $10 \mathrm{ppt}$ ) for 2 3 months. Cattails and several other brackish marsh species invaded and dominated the intertidal zone. As has been shown experimentally by Beare (1984, Beare and Zedler 1986), the adult cattails readily tolerate saline conditions. Some individuals in experimental treatments survived a year in 45 ppt water; aboveground parts died, but rhizomes were able to resprout when freshwater was resupplied. Thus, the limiting factors for invasion are seed germination, which declines to near-zero at $20 \mathrm{ppt}$, and the period of time required for the cattails 10 grow salt-tolerant rhizomes (estimated to be 2 to 3 months).

Table 3.4. Species that Boland (1981) saw feeding in the river and temporary pools at Tijuana Estuary. Data are frequency, i.e., the number of visits when a species was seen as a $\%$ of the total number of visits to each habitat $(n=10$ visits to the river and 8 visits to pools).

\section{$\begin{array}{lll}\text { Species River Pools } & \end{array}$}

\begin{tabular}{llr}
\hline Least and western sandpipersa & 45 & 88 \\
Dowitcher & 50 & 25 \\
Willet & 20 & 63 \\
Greater yellowlegs & 10 & 50 \\
Black-necked stilt & 80 & 63 \\
American avocet & 10 & 38 \\
Semipalmated plover & 10 & 25 \\
Killdeer & 90 & 100 \\
Black-bellied plover & 20 & 25 \\
Total birds censused & 226 & 1,019
\end{tabular}

aData for the two species were averaged. 
Once brackish species have invaded an intertidal area, it is likely that they will persist. With continually augmented streamflows, as would occur with upstream wastewater discharges, species with salttolerant, vegetatively reproducing adults might never die out. At San Diego River marsh, the cattail population that invaded in 1980 enjoyed a second expansion in 1983, when rainfall and streamflow continued late into spring. With drier conditions in 1984 and 1985, the population declined (Zedler and Beare 1986).

\subsection{ESTUARINE CHANNELS AND TIDAL CREEKS}

The channel habitats are important for a wide variety of organisms including macroalgae, phytoplankton, invertebrates, fishes, and birds (Flgure 3.18). The California least tern and other fish-eating species feed in the deeper-water habitats, while shorebirds probe the sediments of the intertidal zone at low tide.

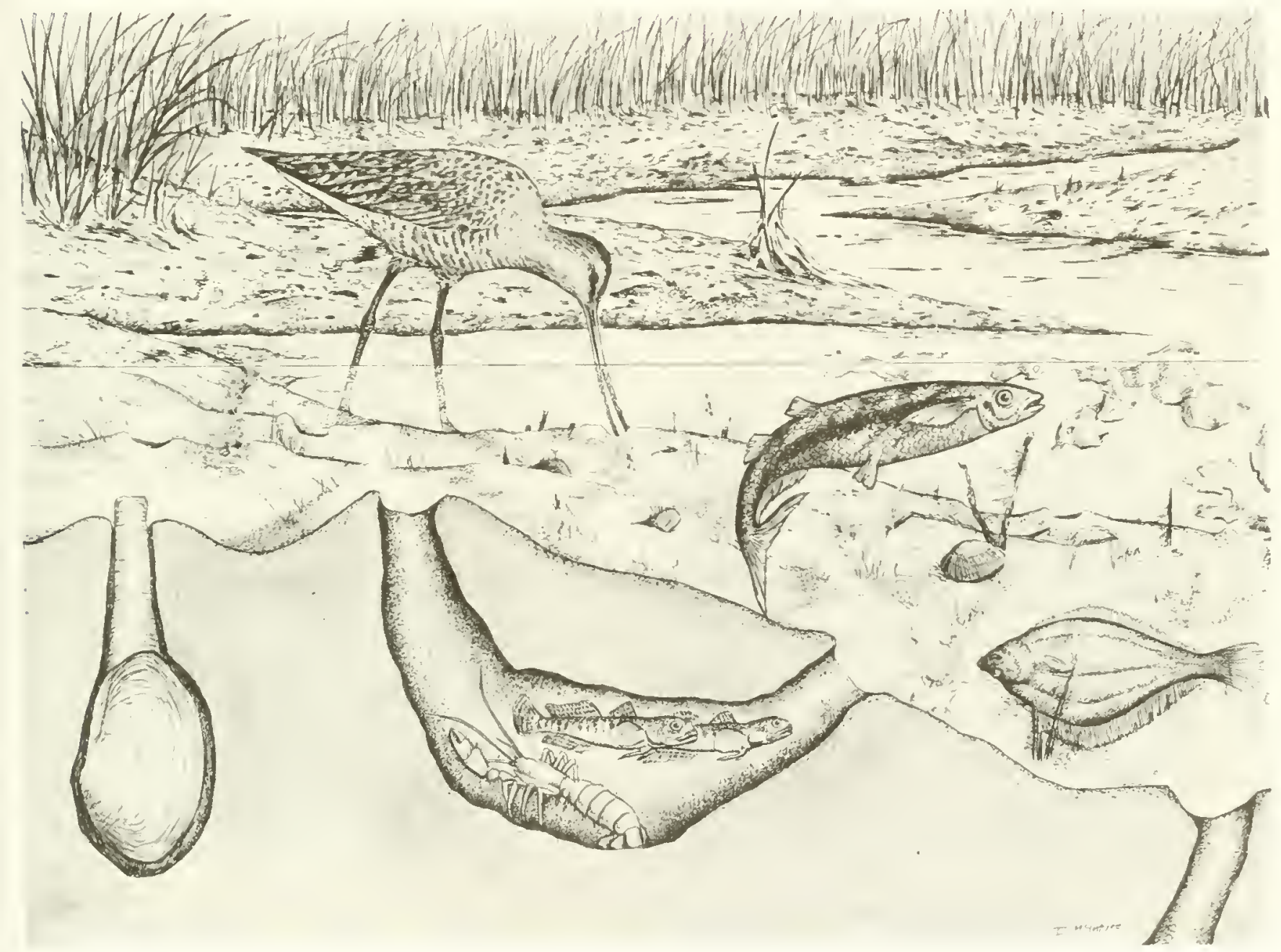

Figure 3.18. The channel and tidal creek habitats support an abundance of species including the marbled godwit, which probes the mud for food, the topsmelt, which attaches its eggs to macroalgae, the diamond turbot, which feeds on the benthic organisms, and gaper clams (Tresus nuttallii), ghost shrimp, and commensal arrow gobies, which live within the sediments. Mclntire collection, (c) 1986 by Zedler. 
Channels are subjected to a wide range of environmental conditions. Tidal flushing is greatest at the mouth and decreases with distance from the mouth; this general gradient in turn influences water movement, salinity, temperature, nutrients, and dissolved gases. Finer sediments are removed by higher current velocities, so that substrates near the mouth have coarser sediments than in tidal creeks. Nutrients brought into the estuary by tidal flushing are more readily available to organisms near the mouth. Temperature, salinity, and dissolved oxygen are less variable in areas of deep water than in tidal creeks. These environmental factors influence the species composition, distribution, and population dynamics of the channel organisms.

\subsubsection{Algae}

The obvious plants of intertidal and subtidal areas are the macroalgae. Vascular plants such as eelgrass (Zostera marina) are absent, perhaps because the area of shallow water is too small or too dynamic for rooted plants to become established. However, large populations of Enteromorpha sp. and/or sea lettuce (UIva sp.; Figure 3.19) sometimes develop on the channel bottoms and later float to the water surface (Rudnicki 1986). Seasonal distribution patterns are highly variable, but their abundance is usually greatest in spring (Chapter 4).

Phytoplankton are also variable in species composition and density. Dinoflagellates (e.g., Gymnodinium spp.), diatoms, filamentous blue-green algae (cyanophytes), and unidentified unicells or "monads" are all present in the water column (Figure 3.19; Fong 1986). While most of these algae are typical planktonic species, the diatoms are all pennate forms with bilateral symmetry and longitudinal grooves that allow locomotion on substrates. Fong (pers. comm.) believes that most of these are resuspended from the sediments.

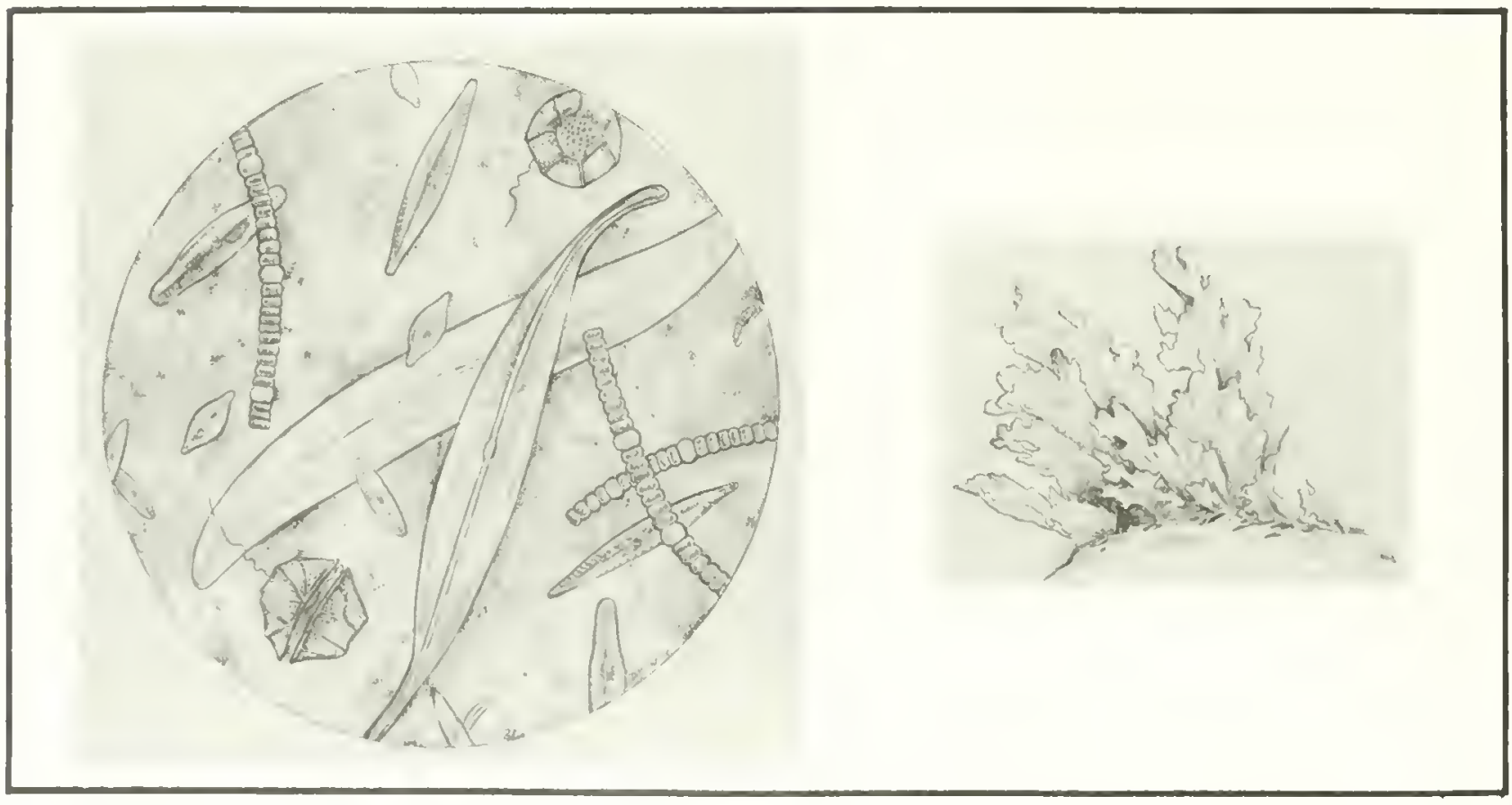

Figure 3.19. Channel producers include a phytoplankton community (on left) with blue-green algal filaments, dinoflagellates, such as Gymnodinium, and diatoms, such as the sigmoid Pleurosignma and Gyrosigma, and many species of Navicula. In addition, there is often an attached or floating mat of macroalgae (such as Uiva, on the right). McIntire collection, (c) 1986 by Zedler. 
The monads are so tiny (ca. 1-2 microns diameter) that identification is challenging; they appear to belong to the Cyanophyta ( $P$. Fong, SDSU, pers. comm.). Many of the phytoplankton species also occur in nearshore habitats, where their densities are lower. From March to June, there may be phytoplankion blooms in the estuary, with cell counts higher than in marine waters by one to two orders of magnitude.

Both Rudnicki (1986) and Fong (1986) associated algal blooms with reduced tidal flushing. The air photo of March 1984 (Figure 2.10) showed high biomass of macroalgae in tidal creeks and along the shores of the abandoned sewage lagoons. Because the 1983 winter storm washed dune sands into the main estuarine channel, tidal flushing became sluggish and algal biomass accumulated. Likewise, algal growth was high during the nontidal period of 1984. Channel waters were green with phytoplankton during the summer (Chapter 4). During the 1985 monthly censuses of channel algae, Rudnicki and Fong found the highest biomass of both macroalgae and phytoplankton in small tidal creeks where current speeds were low.

\subsubsection{Benthic Invertebrates}

Studies of invertebrates at Tijuana Estuary have included resource inventories and short-term or species-specific investigations. Several investigators (Bybee 1969; Mclllwee 1970; Ford et al. 1971; Smith 1974; Peterson 1975; International Border Water Commission 1976; D. Dexter, SDSU, unpubl. data; and White and Wunderlich, unpubl.) depicted the invertebrate community prior to flooding in 1978. More than 75 species of invertebrates, primarily benthic forms, were identified during this period (Table 3.5).

Additional studies documented the effect of the 1980 flood (Rehse 1981) and the nontidal period of 1984 (Griswold 1985). Griswold's observations and continuing monitoring by Dexter documented recolonization in 1985 by invertebrate species that died during the 1984 warm hypersaline conditions. In early
1986, however, most of the recolonists died out again under conditions of continual spills of raw sewage from Mexico. The present benthic macrofaunal community is very different from that described in the 1970's.

Before 1980, the benthic community was dominated by bivalve molluscs, especially the purple clam (Sanquinolaria nuttalli), littleneck clam (Protothaca staminea), false mya (Cryptomya californica), California jackknife clam (Tagelus californianus), and bent-nose clam (Macoma nasuta). Polychaete worms, gastropod molluscs, and decapod crustaceans were also numerically important (Figure 3.20). Bivalve populations were sufficiently dense that hundreds of recreational clammers often took their limit on weekends (Mclllwee 1970). In addition, ghost shrimp (Callianassa californiensis) were hydraulically harvested as bait (Bybee 1969).

The distributions of infauna are strongly influenced by sediment type. Most larval settlement is limited by substrate availability and adult distributions are influenced by grain size, $\mathrm{pH}$, total organics, organic carbon and nitrogen, and dissolved oxygen. Filter feeders, such as the dominant bivalves, are associated with medium-sized grains because finer sediments contain too little organic material in suspension and because coarser sediments are too unstable. Finer sediments may also act to clog the filtering mechanisms. Deposit feeders, such as ghost shrimp and certain polychaetes, often occur on finer sediments, which have higher concentrations of organic carbon and nitrogen, but less dissolved oxygen and lower $\mathrm{pH}$.

Hosmer (1977) found that distributions were correlated with sediment type for six species of bivalve molluscs that were common at Tijuana Estuary. Overall, there was a significant decrease in biomass of molluscs with smaller grain size, and the largest individuals were found in coarse, well-sorted sediments. Individual species exhibited a variety of patterns. The remaining nine species of bivalve molluscs found by Hosmer (1977) were not encountered frequently enough to characterize their distribution patterns. 
Table 3.5 Cumulative species list of invertebrates recorded from Tijuana Estuary through 1991. Family names are listed where taxonomy was unclear.

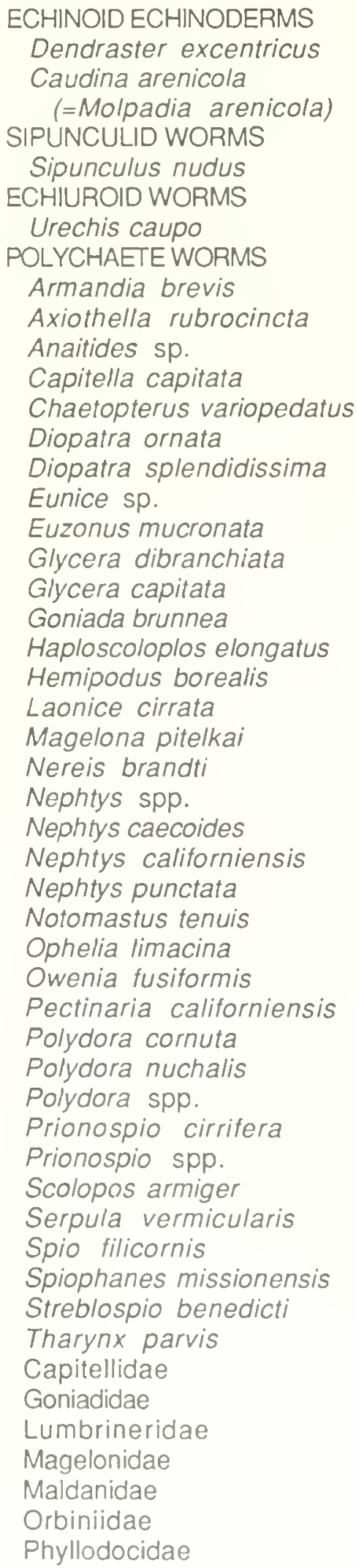

$$
\text { Syllidae }
$$

BIVALVE MOLLUSCS

Chione californiensis

Chione fluctifraga

Chione undatella

Cistenides brevicoma

Cryptomya californica

Cooperella subdiaphana

Crassostrea sp.

Diplodonta orbella

Donax californicus

Leporimetis obesa (=Florimetis obesa)

Laevicardium substriatum

Leptopectin latiauratus

Lucina nuttalli

Macoma nasuta

Macoma secta

Mactra californica

Mytilus edulis

Ostrea lurida

Protothaca laciniata

Protothaca staminea

Nuttallia nuttallii

(=Sanguinolaria nuttalli)

Saxidomus nuttalli

Siliqua patula

Tagelus californianus

Tagelus subteres

Tellina carpenteri

Tellina modesta

Tresus nuttallii

Musculista senhousia (=Musculus senhousia)

Spisula planulata

Solen rosaceus

GASTROPOD MOLUSCS

Acteocina inculta

Aplysia californica

Assiminea californica

Bulla gouldiana

Cerithidea californica

Crepidula fornicata

Cylichnella culcitella

Melampus olivaceus

Nassarius fossatus

Nassarius tegula

Navanax inermis

Olivella baetica

Olivella biplicata

Polinices lewisii
Crepidula onyx

Collisella limatula

Haminoea vesicula

Serpulorbis squamigerus

DECAPOD CRUSTACEANS

Callianassa californiensis

Callianassa gigas

Cancer sp.

Emerita analoga

Hemigrapsus oregonensis

Loxorhynchus crispatus

Pachygrapsus crassipes

Pinnixa franciscana

Portunus xantusii

Scleroplax granulata

Malacoplax californiensis

(=Speocarcinus californiensis)

Uca crenulata

Upogebia sp.

Callianassa affinis

Cancer antennarius

Cancer productus

Spirontocaris palpator

Pagurus hirsutiusculus

Pagurus samuelis

CIRRIPED CRUSTACEANS

Balanus glandula

Balanus amphitrite

ISOPOD CRUSTACEANS

Excirolana chiltoni

AMPHIPOD CRUSTACEANS

Eohaustorius washingtonianus

Jassa falcata

Orchestia traskiana

Ampithoe plumulosa

CNIDARIA (COELENTERATES)

Renilla kollikeri

Corymorpha palma

NEMERTEA

Carinoma mutabilis

unidentified species

PLATYHELMINTHES

Stylochus sp.

Stylochus franciscanus

TURBELLARIA

unidentified species

HEMICHORDATA

Saccoglossus sp.

PHORONIDA

Phoronis architecta

BRACHIOPODA

Glottidia albida 
Purple clams were present throughout a wide range of sediments. Higher biomass and densities were recorded in coarse sand, decreasing with finer sediments. This species was absent from sediments with high siltclay contents. Littleneck clams occurred in very coarse to fine sediments with highest densities in finer sediments. Maximum biomass and density were found in 15\%-20\% silt/clay. False mya occurred in all sediment types from very coarse to very fine sand. Biomass and densities were bimodal, with highest values at around $35 \%$ silt/clay. California jackknife clams were collected in medium to fine sand. Biomass and density increased with a decrease in sediment size. Biomass was highest at $5 \%$ $10 \%$ silt/clay; density peaked at 20\%-25\% siltclay; and size tended to decrease with higher silvclay percentages. The bent-nose clam was found in sediments ranging from coarse sand to very fine sand. Biomass and density increased with a decrease in sediment size. Density and biomass were optimum at about $15 \%$ siltclay. The white sand clam (Macoma secta) was found only in medium to fine sandy sediments and had the narrowest grain size distributional range. Both biomass and size of white sand clams were fairly constant with changes in grain size, although density was higher in medium sand.

Water depth also influences the benthos. In her study of littleneck clams, Smith (1974) concluded that size and density increased with increasing tidal depth. She found average densities as high as 207/0.25 $\mathrm{m}^{2}$ in the subtidal areas compared to $20 / 0.25 \mathrm{~m}^{2}$ in the intertidal zone. She cited sediment grain size, temperature, salinity, duration of feeding time, and probability of predation as factors affecting survivorship of this species. Increased food availability and substrate stability are also associated with deeper water.

Niesen (1969) sampled areas near the mouth of Tijuana Estuary to characterize the sand dollar (Dendraster excentricus) population. Densities at that time ranged from $60-250 / \mathrm{m}^{2}$ with a mean of $170 / \mathrm{m}^{2}$ $(n=10)$. This species died out after storms and flooding in 1978 lowered water salinities
(Dexter, pers. comm.). It was not recorded again until Griswold found small population on a sandy area of the main north channel in 1985. The largest individuals recorded were $13 \mathrm{~mm}$ in diameter.

The dominant crustacean in the estuary was the ghost shrimp, which was studied by Homziak (1977). As recently as the 1970's, it was commercially harvested as fish bait. Hosmer (1977) investigated its competitive interactions with two sympatric burrowing shrimp of the same family: Callianassa gigas and a Upogebia species. His work suggested that the distribution and abundance of $C$. californiensis and Upogebia species are determined by specific substrates, while $C$. gigas appears to be controlled by competitive interaction with the other two species, due to broad overlap in substrate and food exploitation.

Peterson (1975) compared the benthos at Tijuana Estuary and Mugu Lagoon, $300 \mathrm{~km}$ to the north. He examined the subtidal, sandy bottom habitats of the two areas and found that the dominant macroinvertebrates each occupied a characteristic depth within the sediments. Sand dollars occupied the top few centimeters (Figure 3.20) and each had most of its test exposed to the water column. Littleneck clams were found within the top 6 $\mathrm{cm}$. Ghost shrimp and its obligate commensal, false mya, occurred together at $0-55 \mathrm{~cm}$. There was some overlap with the purple clam, which was found at $25-55 \mathrm{~cm}$. The California jackknife clam burrowed up to $60 \mathrm{~cm}$ deep. Peterson attributed their vertical separation to competition for space, because there was little segregation in food utilization. All but one were suspension feeders; thus, they used the same food source, regardless of burial depth.

Tijuana Estuary and Mugu Lagoon had similar dominant species, but densities and relative abundances were very different (Table 3.6). The purple clam and California jackknife clam were much more abundant at Tijuana Estuary, which Peterson (1975) thought was due to the rarity of other deepburrowing competitors. Hydraulic harvesting 


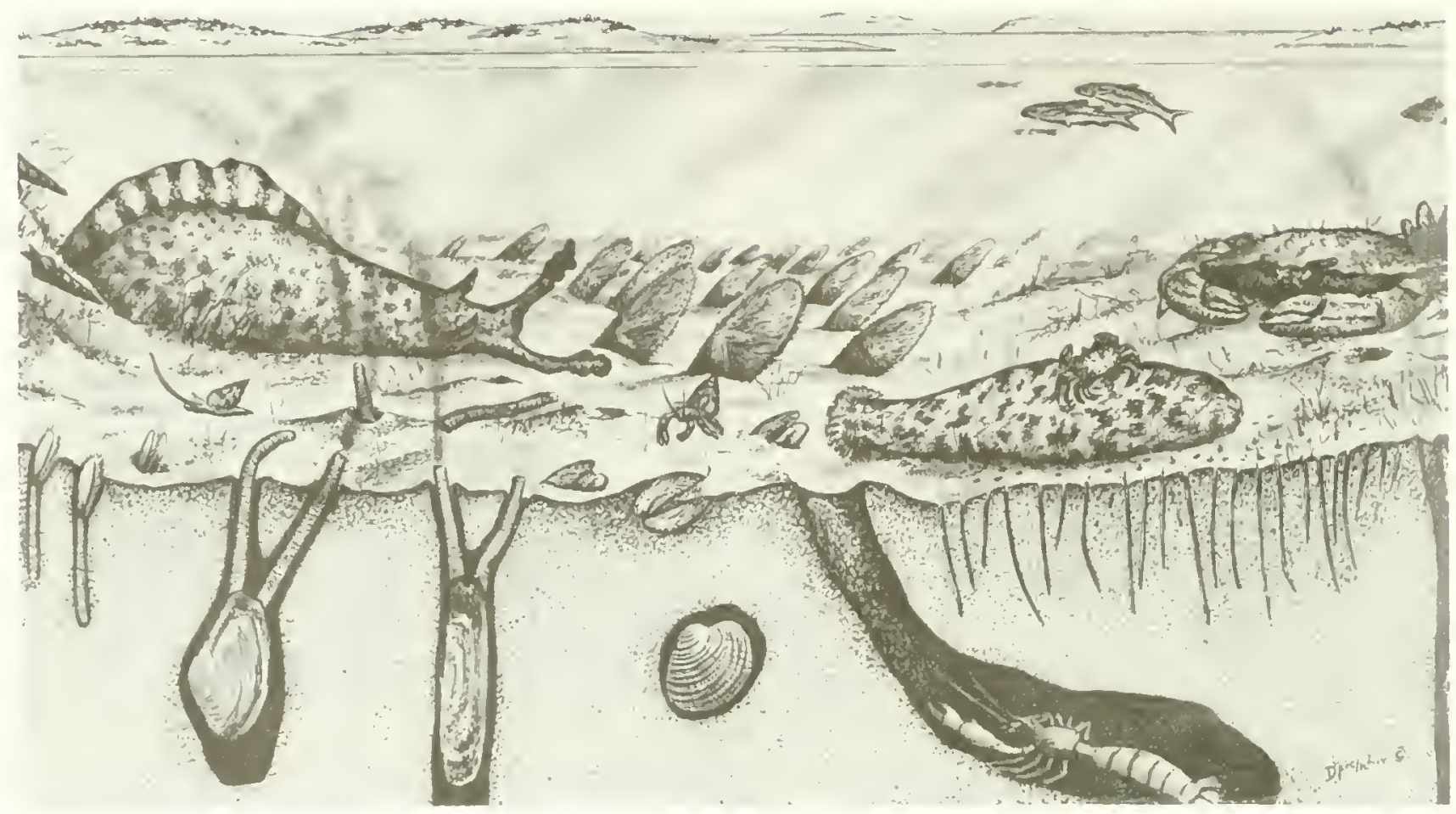

Figure 3.20. The channels suport a wide variety of animals. Illustrated are mullet in the water column and benthic animals, from left to right: the horn snail, sea hare (Aplysia), mud snails (Nassarius), sand dollars, hermit crabs (Pagurus), egg cockle (Laevicaroium), sea cucumber (Molpadia) and its commensal pea crab (Pinnixia barnharti), and the crab (Cancer productus) with attached mussels (Mytilus edulis). Burrowing in the sediments are, from left to right: the mud-flat brachiopod (Glottidia albida), bent nose clam, California jackknife clam (Tagelus claifornianus), wavy chione (Chione undatella), ghost shrimp, and spionid worms. Mclntire collection, (c) 1986 by Zedler.

of callianassid shrimp was common at Tijuana Estuary during the 1960's and 1970's; their removal, according to Peterson, allowed the clams to expand their populations with little effect on other dominant species. Manipulative field experiments supported his interpretation of the data.

During the winters of $1977.78,1978$. 79, and 1979-80, San Diego County had unusually heavy rains, culminating in the flood of 1980 when approximately twice the normal precipitation and 28 times the mean annual streamflow were recorded. The influx of fresh water lowered channel salinity to zero ppt, and the increased streamflow significantly altered the sediment structure of the channel bottoms. Sediment grain size decreased at three of five sampling sites and increased at two (Rehse 1981).

These shifts in grain size allowed a test of three predictions from Hosmer's (1977) study: 1) The purple clam should be most affected, because it was confined to coarser sediments; 2) the littleneck clam should be less affected because its highest density and biomass were at $15 \%-20 \%$ siltclay; and 3 ) the false mya should be least affected, because their maximum biomass and densities were at $35 \%$ silt/clay. 
Table 3.6. Average density (number $/ \mathrm{m}^{2}$ ) and percent of total individuals (relative abundance) for each of the most numerous species of sandy bottom communities at Mugu Lagoon and Tijuana Estuary (modified from Peterson 1977).

\begin{tabular}{|c|c|c|c|c|c|}
\hline \multirow[b]{2}{*}{ Species } & \multirow[b]{2}{*}{ Common name } & \multicolumn{2}{|c|}{ Mugu Lagoon } & \multicolumn{2}{|c|}{ Tijuana Estuary } \\
\hline & & Density & $\%$ & Density & $\%$ \\
\hline Cryptomya californica & false mya & 269 & 47 & 2 & I \\
\hline Callianassa californiensis & ghost shrimp & 87 & 15 & 3 & 2 \\
\hline Protothaca staminea & littleneck clam & 58 & 10 & 35 & 19 \\
\hline Sanguinolaria nuttalli & purple-hinged clam & 46 & 8 & 75 & 42 \\
\hline Dendraster excentricus & sand dollar & 36 & 6 & 23 & 12 \\
\hline Tagelus californianus & jackknife clam & 9 & 2 & 14 & 8 \\
\hline
\end{tabular}

In 1980, Hosmer resampled several areas that were included in his 1977 thesis work, and Rehse (1981) compared the two data sets on bivalves and callianassid shrimp. Flooding caused mass mortalities of many species. Absent from the 1980 collections were the yellow clam (Florimentis obesa), egg cockle (Laevicardium substriatum), bentnose clam, white sand clam (Macoma secta), California mactra (Mactra californica), Washington clam (Saxidomus nuttalli), Carpenter's tellen (Tellina carpenteri), and Callianassa gigas. The dominant bivalve before the 1978-80 period was the purple clam, while the dominant in 1980 was false mya.

Juvenile recruitment was high after the 1980 floods, particularly for ghost shrimp, whose density increased $72 \%$ while biomass decreased $95 \%$. Significant decreases in mean size were also recorded for ghost shrimp, blue mud crab, and purple clam, indicating that mass mortality was followed by recruitment. However, the mean sizes of two species (false mya and littleneck clam) were not significantly less than in 1977, which suggested that both survived the stresses of reduced salinity and altered substrate.

These changes support the hypothesis that benthic macrofauna are strongly associated with sediment particle size. Dune washover events and dredging activities also alter substrate type and add to our understanding of substrate dependency. The dredging of Oneonta Slough in 1987 removed some of the sand that was deposited in 1983 but left behind a coarse substrate. Sea storms in December 1986 and December 1987 again added sand to the channel along Seacoast Drive. Despite these disturbances, bivalves continued to persist, although in lower numbers than where wastewater influence was not as severe (Nordby and Zedler 1991). Lowered salinity also contributes to compositional change, as has been shown for both wastewater inflows (cf. Chapter 5 and Nordby and Zedler 1991), and river flooding (Zedler et al. 1984b, Peterson 1975; Onuf 1987).

During 1983, El Niño conditions increased sea levels an average of $15 \mathrm{~cm}$ (R. Flick, Scripps Institution of Oceanography, pers. comm.), which ameliorated the impact of freshwater flooding. Unusual species were noted in the estuary following the 1982-83 El Niño. Swimming crabs (Portunis sp.) were so abundant in 1984 that some people collected them by the bucket for food (Jorgensen, pers. comm.). Casual sampling of the benthos during closure produced mainly polychaete worms (Spionidae, Figure 3.21), amphipods (Corophidae), and water boatmen (Trichocorixia; K. Dyke, SDSU, pers. comm.). The polychaetes and amphipods dominated these collections, constituting $97 \%$ of the 


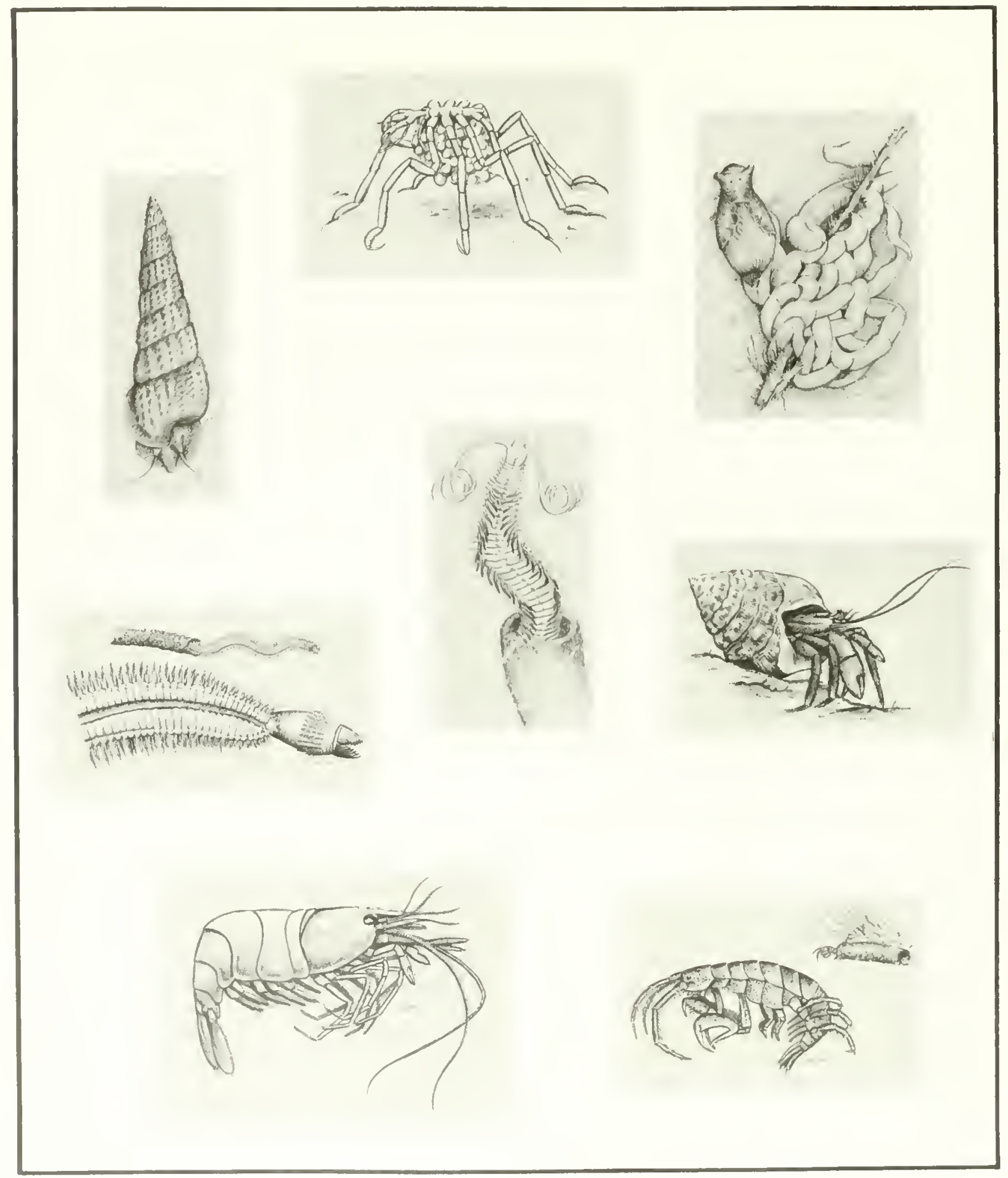

Figure 3.21. Invertebrates of the channels include, in the top row, California horn snail, sea spider (Ammothella biunguiculata var. californica, male with eggs), white bubble snail (Haminoea vesicula); in the middle row, fire worm (Nephtys caecoides), spionid worm (Polydora sp.), hairy hermit crab (Pagurus hirsutiusculus); and on the bottom row, broken back shrimp (Spirontocaris palpator), and amphipods (e.g., Jassa falcata). McIntire collection, (c) 1986 by Zedler. 
specimens taken from both the algae-covered tidal flats and sandy intertidal areas. Mean densities as high as 16,500 animals $/ \mathrm{m}^{2}$ were encountered (Dexter, unpubl. data).

The ability of invertebrates to establish or recover from extreme conditions is largely determined by the availability of larvae (i.e., life history characteristics), but chance also plays a role. Species with large numbers of larvae present at the time when estuarine habitats are accessible and suitable for settling have high probability for recruitment. Within continued hydrologic disturbances (i.e., wastewater inflows through 1991), only the most resilient species (short-lived species with early reproductive age) have persisted (Chapter 5). It is not clear whether there are sufficient sources of larvae of the species that once dominated the estuary. Whether the historic benthic community will ever regain its high species richness, or whether large, old clams will ever be abundant again, remains to be seen.

\subsubsection{Fishes--Adults and Juveniles}

Before the 1978 flood, 29 species of fish were found in Tijuana Estuary (Table 3.7). The community was dominated by goby species, California killifish (Fundulus parvipinnis), striped mullet (Mugil cephalus), and longjaw mudsucker (Gillichthys mirabilis; Figure 3.22), all of which are considered resident species. Commercial/recreational species that used the estuary included California halibut (Paralichthys californicus), surfperches, anchovies, pleuronectids, croakers, and sea bass, although none of these occurred in high numbers relative to resident species.

The distribution and abundance of the fishes were altered by flooding in 1980 and inlet closure and hypersalinity in 1984 . Wastewater inflows in the late 1980's had even greater effects on the fish community (Chapter 5). Changes in water salinity affect the fishes directly by physiological stress and indirectly by elimination of food items.
Nordby (SDSU, unpubl. dala) sampled three sites for adult and juvenile fishes from August to November, 1979, and from midFebruary through March, 1980, using a 1/4 inch mesh seine. Sampling was interrupted from late November to mid-February due to flooding, and the sampling effort was abandoned after mid-March because of floodinduced changes. The data from five sampling dates were dominated by topsmelt and included eight other species. During late January and early February 1980, and again in midFebruary through March, major flooding occurred in the estuary, lowering salinities to 0 ppt. Samples collected after the 1980 flood had fewer species, with topsmelt and mullet most abundant. These data support the findings of other investigators in similar habitats which indicate that species diversity decreases after periods of reduced salinity (Allen 1980, Onuf and Quammen 1983).

The effects on fishes of the 1984 closure to lidal flushing were examined in the fall of 1984 (Donohoe, unpubl. data). At this time the mouth had been closed for approximately six months. As previously mentioned, water levels were lower than normal, salinities were as high as $60 \mathrm{ppt}$, and many areas of former mudflat were sunbaked and cracked. Fish were collected by means of a $1 / 4$ inch mesh bag seine at seven locations. Of the 575 individuals measured, $74 \%$ were topsmelt, $22 \%$ were California killifish, and $4 \%$ were longjaw mudsucker. All of the species collected during mouth closure have wide salinity tolerances (Zedler et. al. 1984b). It is likely that gobies and mullet were undersampled by this sampling technique. Many gobies can take refuge in burrows or pass through a $1 / 4$ inch mesh seine, while mullet can escape around or over most seines. However, both Nordby and Donohoe used the same sampling gear. Thus, it is clear that diversity of fishes was lower in 1984 than in the 1970's.

The most abundant species collected in 1979-80 and in 1984 was topsmelt. A comparison of the length-frequency distribulions of this species demonstrated significantly smaller size during 1984 (Figure 3.23). Wastewater inflows in the 
Table 3.7. Fishes and rays recorded from Tijuana Estuary by Ford et al. (1971), IBWC (1976), White and Wunderlich (unpubl.), and Nordby (1982).

ATHERINIDAE (Silversides):

Atherinops affinis - topsmelt

BATRACHOIDIDAE (Toadfishes):

Porichthys myriaster - specklefin midshipman

BLENNIDAE (Combtooth blennies):

Hypsoblennius gentilis - bay blenny

BOTHIDAE (Lefteye flounders):

Citharichthys spp. - sanddabs

Paralichthys californicus - California halibut

CLUPEIDAE (Herrings):

Sardinops sagax caeruleus - Pacific sardine

COTTIDAE (Sculpins):

Artedius harringtoni - scalyhead sculpin

Leptocottus armatus - staghorn sculpin

CYNOGLOSSIDAE (Tonguefishes):

Symphurus atricauda - California tonguefish

CYPRINODONTIDAE (Killifishes):

Fundulus parvipinnis - California killifish

DASYATIDIDAE (Stingrays):

Urolophus halleri - round stingray

EMBIOTOCIDAE (Surfperches):

Amphistichus argenteus - barred surfperch

Cymatogaster aggregata - shiner perch

Hyperprosopon argenteum - walleys surfperch

ENGRAULIDAE (Anchovies):

Anchoa compressa - deepbody anchovy

Anchoa delicatissima - slough anchovy

Engraulis mordax - northern anchovy

GOBIIDAE (Gobies):

Acanthogobius flavimanus - yellowfin goby

Clevelandia ios - arrow goby

Gillichthys mirabilis - longjaw mudsucker

llypnus gilberti - cheekspot goby

Lepidogobius lepidus - bay goby

Quietula y-cauda - shadow goby
KYPHOSIDAE (Sea chubs):

Girella nigricans - opaleye

LABRIDAE (Wrasses):

Semicossyphyus pulcher - California sheephead

MUGILIDAE (Mullets):

Mugil cephalus - striped mullet

MYLIOBATIDAE (Bat rays):

Myliobatus californicus - bat ray

OPHIDIIDAE (Cusk-eels):

Otophidium scrippsi - basketweave cusk-eel

PLEURONECTIDAE (Righteye flounders): Hypsopsetta guttulata - diamond turbot Pleuronichthys coenosus - C-O turbot Pleuronichthys ritteri - spotted turbot Pleuronichthys verticalis - hornyhead turbot

POECILIIDAE:

Gambusia affinis - mosquitofish

RHINOBATIDAE (Guitarfishes):

Rhinobatus productus - shovelnose guitarfish

SCIAENIDAE (Croakers):

Genyonemus lineatus - white croaker

Menticirrhus undulatus - California corbina

Seriphus politus - queenfish

SCOMBRIDAE (Mackerels):

Scomber japonicus - Pacific mackerel

SERRANIDAE (Sea basses):

Paralabrax clathratus - kelp bass

Paralabrax maculatofasciatus - spotted sandbass

Paralabrax nebulifer - barred sandbass

SPHYRAENIDAE (Barracudas):

Sphyraena argentea - California barracuda

SYNGNATHIDAE (Pipefishes and Seahorses): Syngnathus leptorhynchus - bay pipefish 
late 1980's further damaged the topsmelt population (Nordby and Zedler 1991, Chapter 5). In 1991, the estuary was dominated by arrow gobies and killifish, with very low densities overall (PERL, unpubl. data).

\subsubsection{Ichthyoplankton}

Estuaries are often considered essential spawning and nursery grounds for many fish species. In order to determine the value of estuarine channels to these functions, comparisons with shallow coastal waters are necessary. Nordby (1982) compared the Ichthyoplankton communities of the estuarine channels within Tijuana Estuary with those in adjacent nearshore waters. In addition, comparisons were made between large, main estuarine channels and tidal creeks.

Larvae of 28 taxa of fishes representing 19 families and more than 27 genera were collected during the study period, and eggs from 18 taxa were found (Table 3.7; see lists by species Nordby 1982 and in Zedler and Nordby 1986).

There were distinct differences in the ichthyoplankton assemblages collected from each habitat. Estuarine larvae demonstrated patterns of spatial distribution related to channel morphometry and other channel organisms which indicated spawning habitat preferences.

Tidal creek larval collections were dominated by longjaw mudsucker (Gillichthys mirabilis) and Atherinidae, presumably topsmelt. The longjaw mudsucker is known to prey upon and inhabit the burrows of the yellow shore crab (MacDonald 1975). High densities of these larvae were collected where crab burrows were abundant. Atherinid larvae and eggs were associated with macroalgal mats, primarily Enteromorpha species, that grow in the low tidal-velocity creeks. Topsmelt attach their eggs to the algal blades, and the juveniles and adults feed on the abundant plant material (Allen 1980, Nordby 1982).
A complex of three indistinguishable goby larvae comprised of arrow goby (Clevelandia ios), shadow goby (Quietula y-cauda) and cheekspot goby (Ilypnus gilberti) dominated main channel larval collections (61\%) while longjaw mudsucker made up $29 \%$ of the total. The goby complex larvae were densest at the sampling station closest to the mouth of the estuary, apparently due to substrate preference. The substrate at this site was mud/sand compared to mud and clay/shell substrates of the other main channel sampling stations. The arrow goby was the most abundant post-larval goby collected; they have been reported to live commensally with ghost shrimp (MacDonald 1975). Ghost shrimp burrows were common in mud/sand substrate. Thus, it appears that the distribution of goby complex larvae is related to substrate and interaction with another channel organism.

Because of their position relative to the mouth of the estuary, larvae of the goby complex were tidally transported to the nearshore habitat where they comprised $57 \%$ of the total. These species spawn in low tidalvelocity with associated fine sediments (Brothers 1975); thus, it is doubtful that spawning occurred in the nearshore habitat. Conversely, eggs from nearshore-spawning species, especially Sciaenidae and Pacific sardine (Sardinops sagax caeruleus), were imported to the estuary during flooding tides. These two species comprised $69 \%$ and $12 \%$ of main channel eggs and $70 \%$ and $11 \%$ of nearshore eggs, respectively. However, very few larvae from nearshore species were collected within the main channels, suggesting that most imported eggs are not retained until hatching. The nearshore larval dominants, queenfish (Seriphus politus), white croaker (Genyonemus lineatus) and northern anchovy (Engraulis mordax), were rarely collected within the estuary.

Tidal flushing appears to be a determining factor in the distribution of ichthyoplankton at Tijuana Estuary. The presence of postlarval Sciaenidae within the estuary suggests that some nearshore spawned eggs can hatch or develop there. The transportation of goby species to the nearshore environment is probably fatal. Brothers (1975) measured $98 \%$ mortality for spawned cohorts of arrow 
goby at a similar wetland habitat in Mission Bay $(25 \mathrm{~km}$ north of Tijuana Estuary) and determined that tidal translocation was the major source of mortality for this species.

The Gobiidae larvae that dominate Tijuana Estuary are common to other southern California enclosed bays and estuaries. While not of commercial importance, except as baitfish, these low-trophic-level species are important ecologically in that they make the primary productivity of the estuarine system available to higher order consumers. For example, arrow gobies have been shown to be important food items for California halibut as well as other sport fishes (MacDonald 1975).

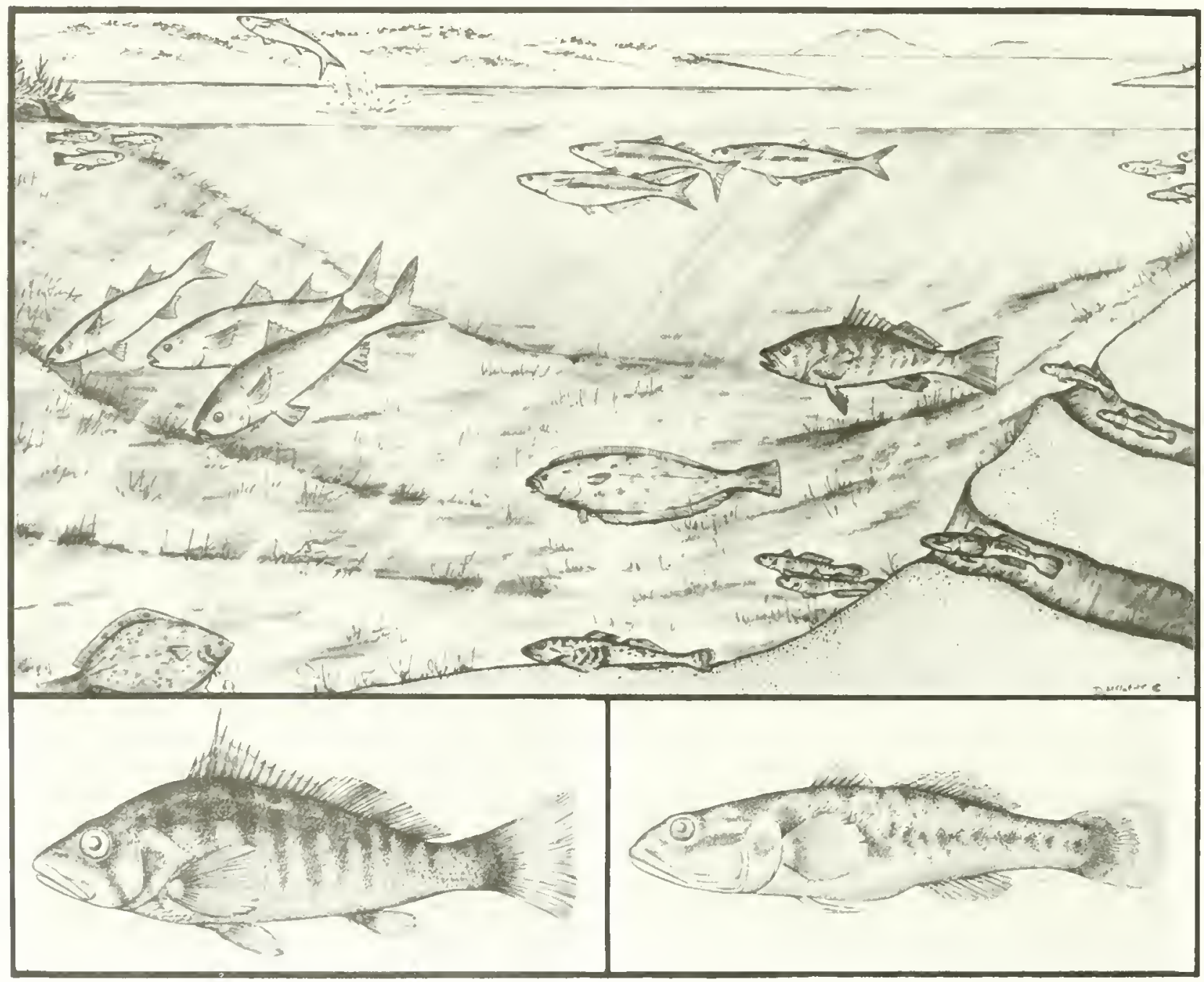

Figure 3.22. The fish community includes killifish (upper left and upper right, in shallow water), mullet (above water and left center), topsmelt (center, near surface), barred sandbass (right, in water column), diamond lurbot (lower left, on substrate), California halibut (center, on substrate), staghorn skulpin (center foreground, on bottom), cheekspot goby, longjaw mudsucker (in lower burrow) and arrow gobies (in upper burrow). Enlarged below are the longjaw mudsucker and barred sandbass. Mclntire collection, (c) 1986 by Zedler. 


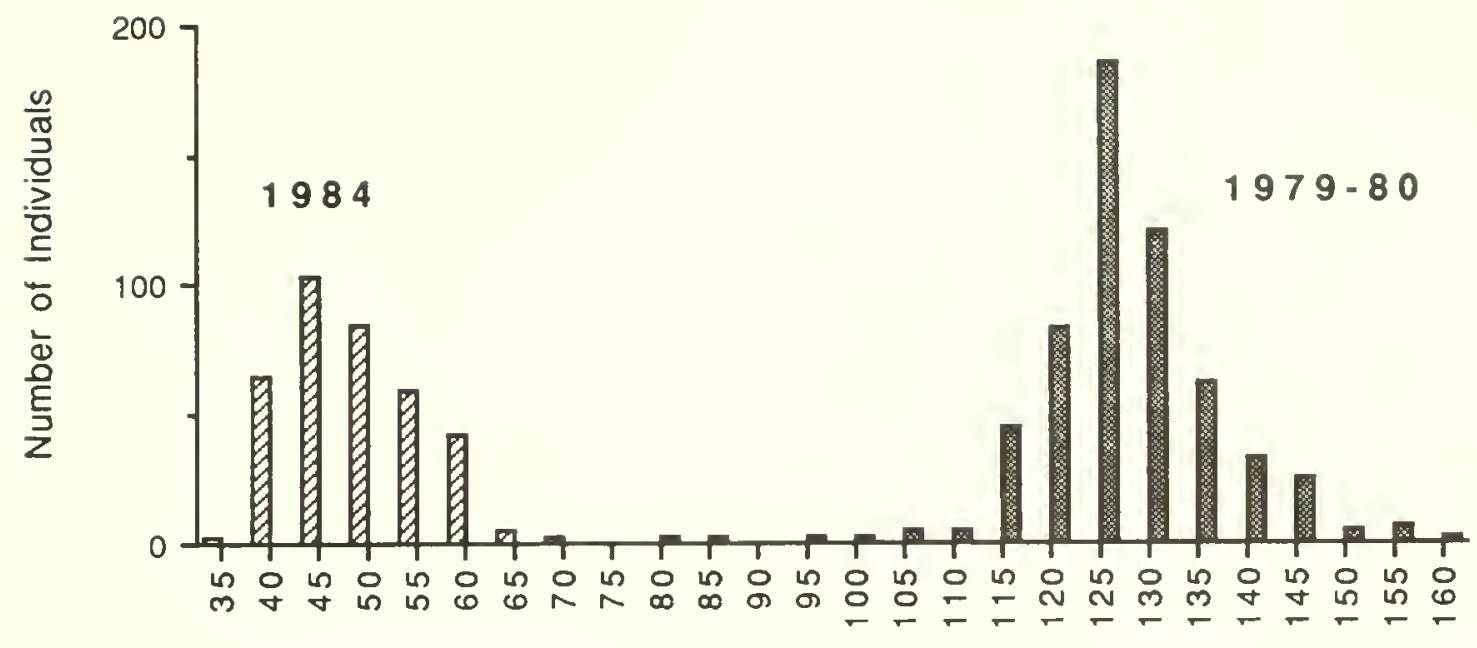

Standard Length $(\mathrm{mm})$

Figure 3.23. Length-frequency distributions for topsmelt collected in Tijuana Estuary in fall and winter, 1979-80 (Nordby, SDSU, unpubl. data) and fall 1984 (C. Donohoe, SDSU, unpubl. data).

\subsubsection{Birds}

The channels of Tijuana Estuary are important foraging and resting areas for a variety of bird life such as great blue herons (Ardea herodias), which prey upon channel fishes (Figure 3.24). Shorebirds forage primarily for invertebrates in the sand and mud sediments and in the water column; diving birds prey upon fishes; wading birds use both fishes and invertebrates for food sources while others, such as dabbling ducks and plovers, feed on vegetation and surface insects, respectively. Three Federal endangered and one California endangered bird species use channel organisms for prey. These include the California least tern, the California brown pelican (Pelecanus occidentalis californicus), the Light-footed clapper rail, and the Belding's Savannah sparrow. Other bird species that feed on fishes in the channels are the belted kingfisher (Megaceryle alcyon) osprey (Pandion haliaetus), and double-crested cormorant (Phalacrocorax auritus).

Several water-associated birds that are rare in California can be seen at Tijuana Estuary. These include the little blue heron

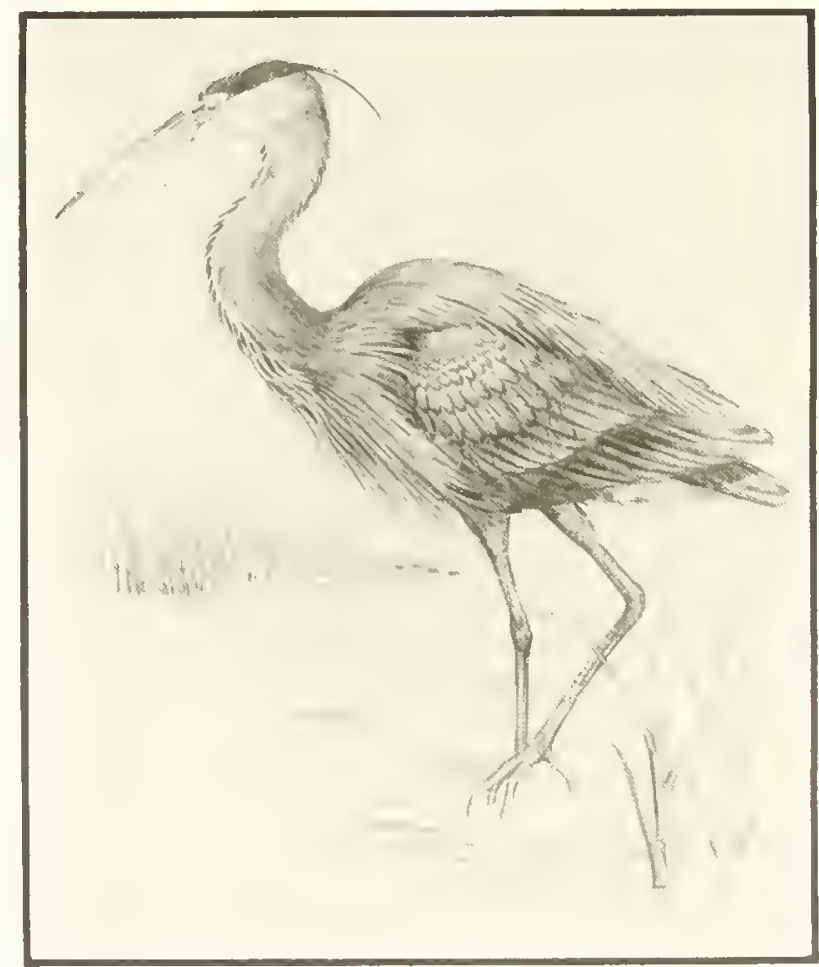

Figure 3.24. The great blue heron. Mclntire collection, (c) 1986 by Zedler. 
(Egretta caerulea), tricolored heron (Egretta tricolor), reddish egret (Egretta rufescens) and black skimmer (Rynchops niger). The black skimmer began nesting at the salt ponds of south San Diego Bay in 1976, and the population has grown rapidly since then (Unitt 1984). Tijuana Estuary is one of the few sites outside of San Diego Bay that skimmers use for foraging.

Channels are important foraging habitats for a variety of birds from other habitats. Belding's Savannah sparrows rely on tidal creek and channel edge habitats for feeding. Clapper rail foraging behavior has been discussed in Section 3.3. Feeding studies of California least terns (Minsky 1984; Atwood and Minsky 1983) document feeding in nearshore waters, as well as estuarine channels and bay habitals. Preferred fishes include northern anchovy, topsmelt, and jacksmelt (Atherinops californiensis). Breeding adults catch and feed these small fish $(4-9 \mathrm{~cm}$ long) to the chicks. The young begin to fly at about 20 days of age and the fledglings develop foraging skills in calm, protected waters. "Even estuarine and freshwater localities that are distant from active nesting sites . . . may be heavily used by least terns during post-fledgling dispersal; loss or disturbance of such areas may reduce the survivorship of dependent young" (Atwood and Minsky 1983).

\subsection{INTERTIDAL FLATS}

The conspicuous species of the sandflats and mudilats are the shorebirds that feed and rest there during low tide (Figure 3.25). Most of their invertebrate food species were discussed in Section 3.6.2. Many of the prey animals are distributed from the subtidal channels to the lower limit of the salt marsh.

Four invertebrate species that are characteristic of exposed flats are the California horn snail, the yellow shore crab, the fiddler crab and the lined shore crab (Figure 3.25). There are no quantitative data on any of these at Tijuana Estuary. We know only that the horn snails can be extremely abundant (hundreds to thousands per square meter), and that both horn snails and crabs are important foods for the clapper rail (Jorgensen 1975). It is likely that all these species were negatively affected by estuarine closure in 1984. Large numbers of emply horn snail shells were collected from the mudflat adjacent to the inland lagoons in 1984; only an occasional live individual was found. Lined shore crabs were found dead and floating in the hypersaline water during 1984.

In a study of habitat utilization and feeding strategies of shorebirds at Tijuana Estuary, Boland (1981) found that intertidal mudflats and sandflats were used by many more species and individuals than any other habitat type. He observed that the species that fed in these habitats appeared to partition their activities among different sediment depths and water depths (Figure 3.26). Waders, such as the greater yellowlegs, fed on items in the water column and on the sediment surface. Longbilled sandpipers (e.g., marbled godwit) probed deep into the sediment, often wading deep into the water. Short-billed sandpipers like the western sandpiper probed less deep and remained near the edge of the water; while plovers (e.g., semipalmated plover) fed on the surface of moist-to-dry sediments.

Boland concluded that the length of leg and bill determined the feeding position of each species, and that the community was composed of species that differed in leg and bill lengths. Such different morphologies should reduce competitive interference by reducing overlap in where the birds feed. However, as Boland pointed out, tides constantly change the depth of water so theat longer and shorter legged birds may take foods from the same spots but at different times. Thus, they cannot avoid exploitative competition when food supplies are limiting. Boland (1988) has tested these ideas through gut analyses of eight shorebird species and quantitative analyses of invertebrate food availability at Morro Bay in central California. He found that food was limiting during winter and spring, and that exploitative competition occurred among many of the species--even among species that had different morphologies (e.g., dunlin, willet, and marbled godwit). 

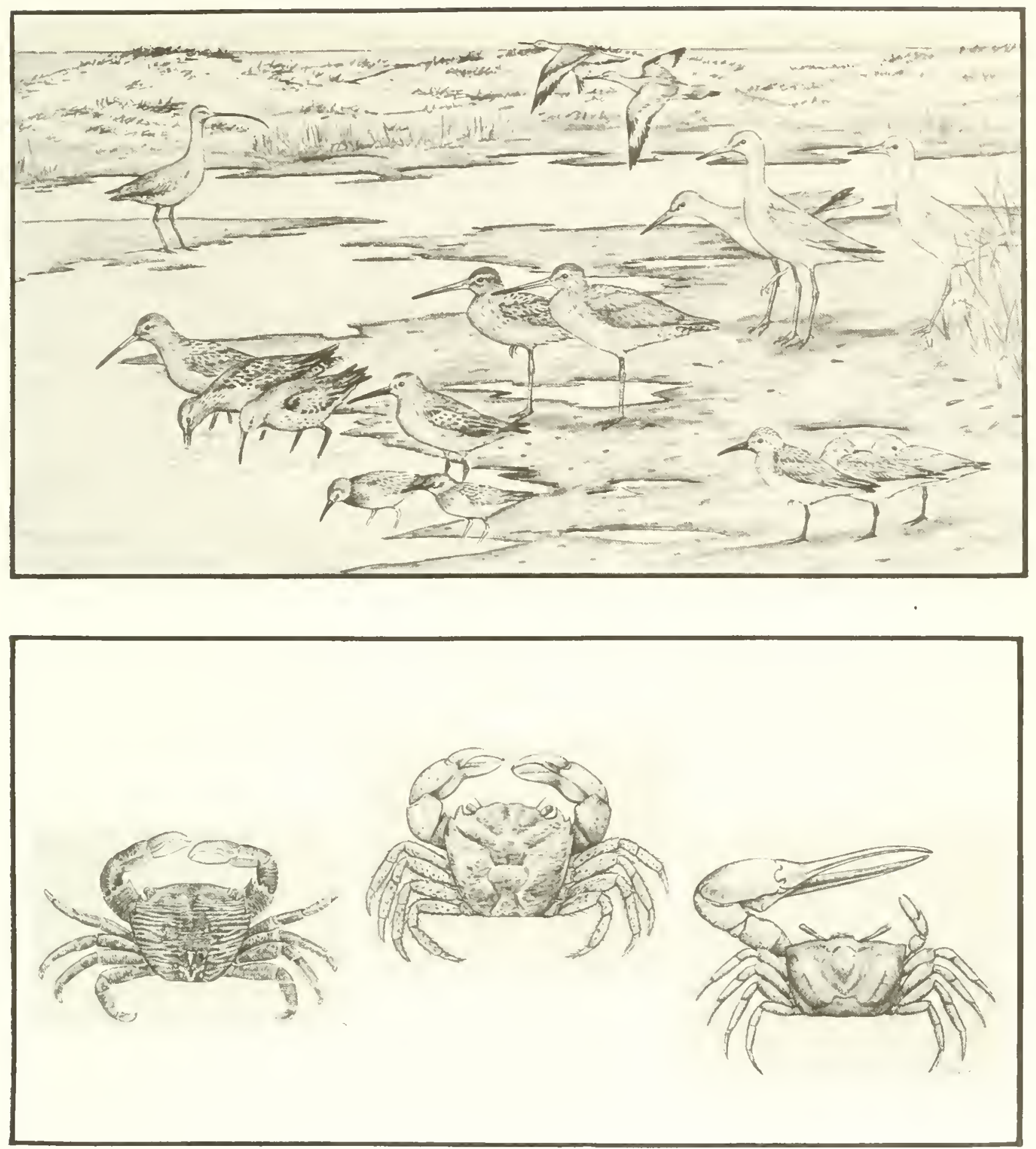

Figure 3.25. Birds of the intertidal flats include the long-billed curlew (upper left) and willets (five larger birds on right; wing bars visible on the two in flight). In the foreground of the mudflat are two least sandpipers (the smallest shorebirds) and three western sandpipers (lower right). Long-billed dowitchers are shown in the center of the mudflat (two on the left and two in the middle), with two dunlins (black patch on shoulder) just behind the least sandpipers. All are drawn in their winter plumage, as usually seen at Tijuana Estuary. The macroinvertebrates of this habitat include lined shore crabs, yellow shore crabs, and abundant fiddler crabs (below, from left to right). Mclntire collection, (c) 1986 by Zedler. 
Water Depth $(\mathrm{cm})$
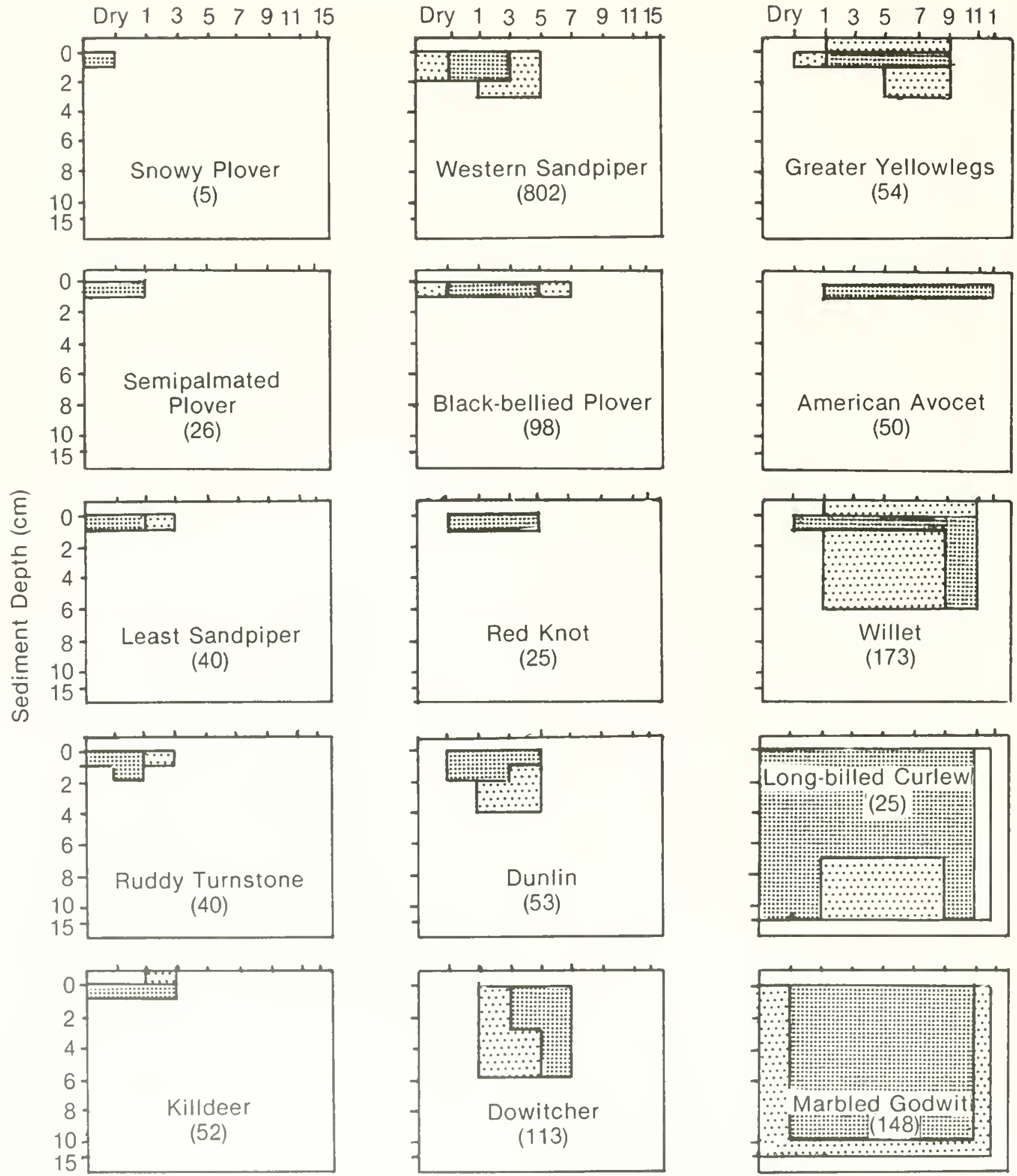

Figure 3.26. Foraging microhabitats (entire stippled area) of shorebirds for sandflats and mudflats. Areas where birds foraged were defined by water depth and depth to which birds probed the sediments; dense stippling indicates where species spent more than $80 \%$ of their time foraging; sample sizes are in brackets. Reprinted from Boland (1981) with permission. 
While there were no studies that quantified the effect of estuary mouth closure on shorebirds, Jorgensen (pers. comm.) estimates that shorebird abundance was reduced $70 \%$ during this period, an effect attributed to the absence of tidal submergence and exposure of bottom sediments. Since the sandy shore habitat was not affected by the obstruction of the estuary mouth, some species may have shifted to this habitat for feeding or may have migrated to other intertidal flats in the region. The return of shorebirds to Tijuana Estuary was much more rapid than that of the former dominant bivalves, and a diverse community utilized the mudflat and sandflat habitats during the fall 1985 migration. The potential for recovery appears to be high for migratory species; if suitable habitat is available, birds will use it. The regional impact on birds of temporary habitat losses may never be known.

\subsection{DUNES AND BEACH}

The shoreline is a dynamic habitat, subject to a variety of environmental influences such as wind and wave action, salt spray, high temperature, and moisture stress. A number of plants and animals have become adapted to these factors and many are found only on dunes. Because of this and because most of the habitat in southern California has been destroyed (Powell 1981), dune species are particularly vulnerable to extinction on a local scale. Thus, this small portion of the estuary is of high value to wildlife.

Dunes that are not stabilized by vegetation can be blown or washed away. The original dune vegetation at Tijuana Estuary has been disturbed by construction and recreation activities that resulted in the denudation of the system. In the winter of 1983, storms washed the dunes into the main channel of the estuary.

Before housing development in the late 1940's and early 1950's, the vegetation of the Tijuana Estuary dune system was similar to that of the Silver Strand, approximately 3 $\mathrm{km}$ to the north (Table 3.8). Plant species such as dune primrose (Camissonia cheiranthifolia), sand verbena (Abronia maritima), and dune ragweed (Ambrosia chamissonis) were present (Figure 3.27). The dunes were stable and did not change position significantly. Following human impacts, some native species, most notably the shrub, lemonadeberry (Rhus integrifolia), were eliminated, while several exotics, such as hottentot-fig (Carpobrotus edulis), sea rocket (Cakile maritima), and Atriplex species invaded.

Brian Fink set out to determine what the natural distribution of native dune plants may have been prior to disturbance, so that replanting could be accomplished in microhabitats that were suitable for each species. He carried out stress experiments with three native species at PERL, subjecting potted plants to salt and sand burial (Fink 1987). In addition, he planted each species on the dune at Tijuana Estuary, to observe growth and survival. Camissonia cheiranthifolia ssp. suffruticosa proved to be intolerant of seawater inundation and sand burial and hence was nol recommended for planting along the strandline (Fink and Zedler 1990). Sand verbena (Abronia maritima) and Ambrosia chamissonis were more tolerant of maritime stresses. An unexpected washover event in December 1986 further tested these species' tolerances to seawater inundation and sand burial. Camissonia did not survive (Fink and Zedler 1990).

The exotic dune plants have adverse effects on native plants and animals. The interaction between the exotic sea rocket and the native sand verbena was investigated experimentally by Wood (1987), who found the exotic to have competitive superiority. The hottentot-fig displaces native dune plants (Williams and Williams 1984). If is an extremely aggressive colonizing species, which is why it is sometimes planted to reduce dune erosion. However, where it dominates large areas of coastal sand, it may alter more than just the native vegetation.

Hottentot-fig provides little food or habitat for native insects (Nagano, pers. comm.). Recent research at Tijuana Estuary (S. Snover, in prog.) indicates that native burrowing insects are at a disadvantage under 
Table 3.8. Early information on dune vegetation at Silver Strand, the beach that extends north from Tijuana Estuary (from Purer 1936b). Species present in 1936 and their common names are listed. Taxonomy follows Munz (1974) and (USDA 1982).
Species
Common name
Notes on distribution

Ambrosia maritima

ragweed

Abronia umbellata

sand verbena

Ambrosia chamissonis

dune ragweed

Atriplex leucophylla

salt bush

Cakile edentula a

Camissonia cheiranthifolia

ssp. suffruticosa

Carpobrotus aequilaterale

Mesembryanthemum nodiflorum
M. crystallinum
Rhus integrifolia
ice plant
lemonadeberry

dune primrose seafig

Rhus laurinab

laurel sumac "one of the most conspicuous plants...

forms extensive mats along the dunes

as well as inland... where the sand is unstable"

"grows in more stabilized place in the sand

strand...forming extensive mals"

"holds a conspicuous and important place... in unstabilized areas"

"forms hummocks of sand...associated with Abronia and Ambrosia"

"finds itself at home...close to the ocean"a

"flourishes on the [plain] of the strand"

"a conspicuous feature of the landscape"

"quite well distributed"

"forms large mats"

"growing extensively on the strand

in many places...growth is considerably

slunted...to a mere few inches"

"growing to some 10 feet in height"

aThis species has been entirely replaced by C. maritima, which was absent in 1936 .

bNoted as present at Silver Strand Beach State Park, but not necessarily on the dune.

plants of hottentot-fig compared to conditions under native vegetation. In the laboratory, the dune beetles do not eat the hottentol-fig. In the field, dune beetles and other native insects are less abundant under exotic vegetation. Temperatures are cooler under the hottentot-fig than under the native vegetation, which may slow insect development. Because the phenology (development phases) of some exotic plants differs from that of native plants, this may also affect insects. The sea rocket is eaten by dune beetles, but the plant does not live long enough to support insect growth to maturity (K. Williams, SDSU, pers. comm.). Revegetation of denuded areas must employ native plant species in order to maintain the native flora and fauna (Chapter 6).
Insects are important components of the dune habitat. Several threatened species are found at the Tijuana Estuary dunes (Nagano 1982). The globose dune beetle (Coelus globosus; Figure 3.27), inhabits foredunes and sand hummocks. It burrows beneath the surface of the sand and is most common under native dune vegetation; it is absent from areas covered by hottentot-fig. This beetle is a candidate for Federal listing and is threatened with trampling by humans, vehicles, and horses.

Tiger beetles are threatened by loss of habitat at Tijuana Estuary and elsewhere. The sandy beach tiger beetle (C. hirticollis gravida) and the sand dune tiger beetle ( $C$. latesignata latesignata; Figure 3.27 ) are 

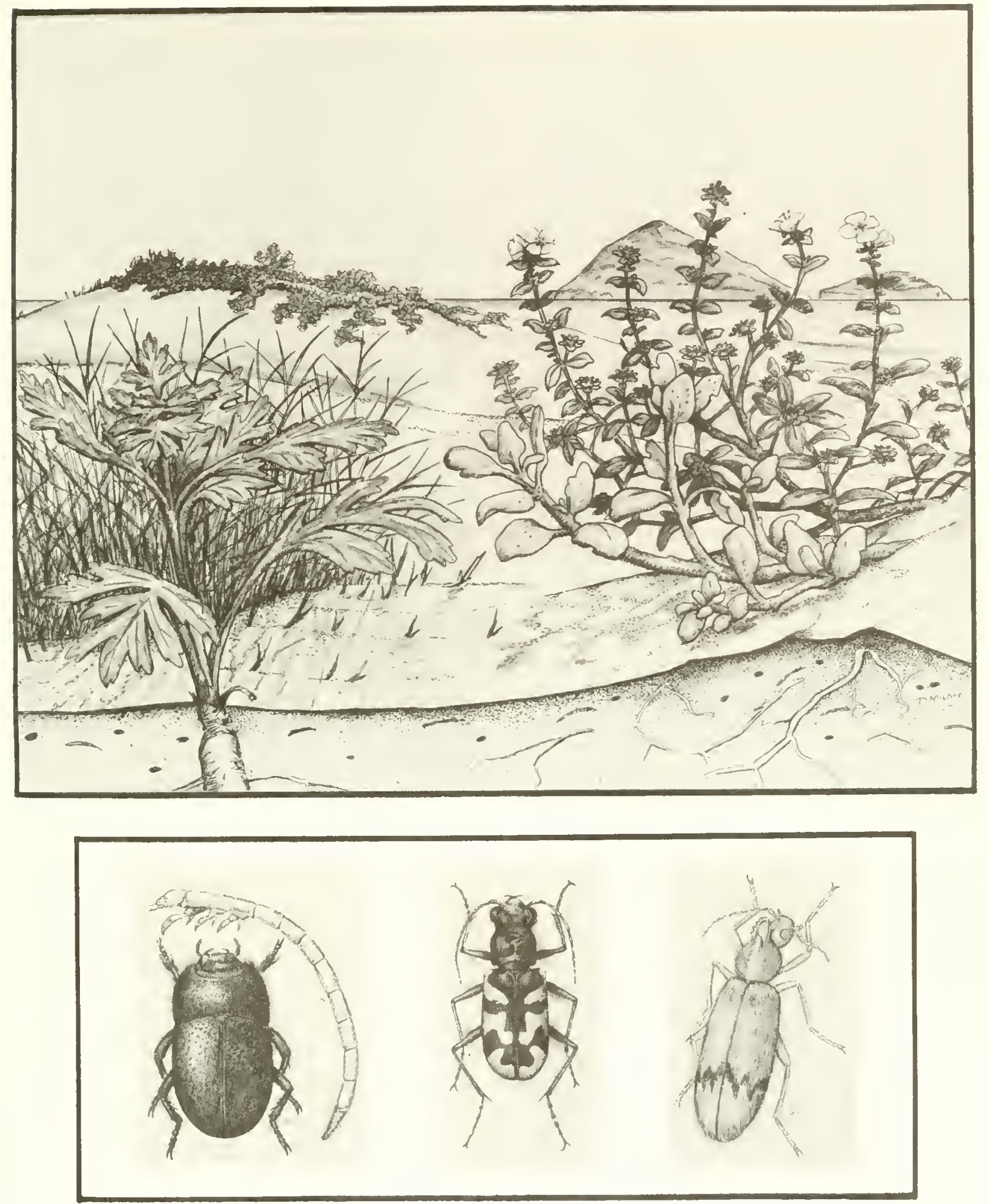

Figure 3.27. The native dune vegetation includes salt grass on the back dune (left), dune ragweed (left foreground), sand verbena (right foreground), and dune primrose. Insects that burrow beneath the plants include the globose dune beetle, the sand dune tiger beetle, and flower beetles (Notoxus). Mclntire collection, (c) 1986 by Zedler. 
found on the dunes (Nagano 1982; Mclntire 1985). Both species lay their eggs in the sand, and the larvae construct vertical burrows approximately the same diameter as the head, from which they trap food in a manner similar to that described in Section 3.4. These beetles are found in only two or three other localities in southern California. Another beetle, Notoxus monodon, feeds on detritus beneath dune vegetation (Figure 3.27). This species has glossy white hairs on its body, presumably to protect it from the sun. The larvae inhabit burrows beneath dune plants (Mclntire, pers. comm.).

It is evident from the above discussion that the insects of the dunes are closely associated with the dune vegetation, particularly native species. In contrast, the birds that use the dunes prefer the open sand areas. Two rare species nest on the dunes of Tijuana Esluary (Figure 3.28), and a variety of other species feed on the sandy shores adjacent to the dunes. The dunes also provide a refuge for shorebirds when high tides inundate their feeding areas.

Espinoza (in Entrix et al. 1991) found three species of lizard using the dunes. The San Diego coast horned lizard (Phrynosoma coronalum blainvillei) was found on the southern dunes. It feeds almost exclusively on wood or harvest ants. The silvery legless lizard (Anniella pulchra pulchra) occurred in the same area and was associated with debris and low vegetation, which protects it from desiccation. The side-blotched lizard (Uta stansburiana) was very abundant on the reconstructed dunes.

The Federally endangered California least tern (Figure 3.28) nests in depressions in the sand along the dunes. Their eggs and chicks are vulnerable to a number of terrestrial and avian predators, as well as accidental or intentional disturbances by humans. If the first clutch fails, adult least terns may attempt to nest again. The least tern is a colonial nesting species that prefers sandy dunes with low amounts of dune vegetation and debris (less than 3\%; Minsky et al. 1983). Females lay an average of two eggs in a small depression or scrape in the substrate. Young are fed exclusively on fish by both parents. Young least terns fledge at 3 weeks, and they gradually learn to feed on their own in inland lakes and estuaries.

Also nesting on the dunes is the relatively rare snowy plover (Figure 3.28). This bird is not a colonial nester but often associates with colonies of California least terns (White, pers. comm.). Snowy plovers lay an average of three eggs. Chicks leave the nest within 24 hours of hatching and immediately follow the parents to foraging areas along the sandy shoreline and mudflats. Snowy plovers teed mainly upon invertebrates along the water's edge on the sandy shoreline.

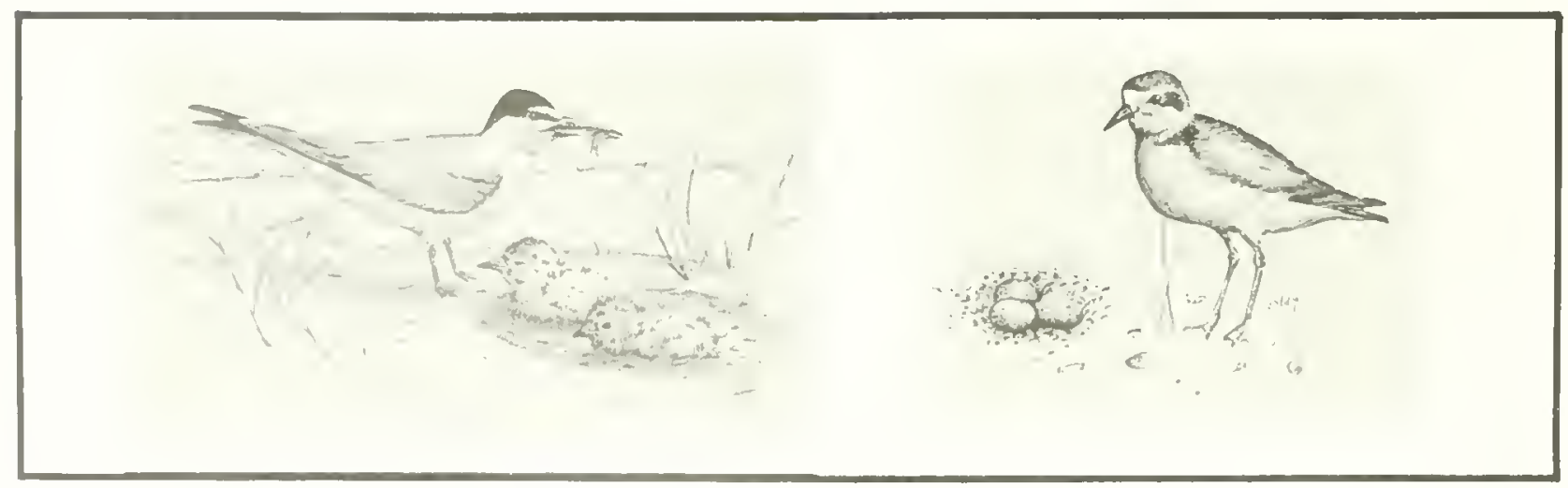

Figure 3.28. Birds that nest on the sand dunes are the California least tern and the snowy plover. Mclntire collection, (c) 1986 by Zedler. 
Boland (1981) found that six species of shorebirds were abundant in his beach study site. These included sanderling, willet, marbled godwit, whimbrel, snowy plover, and black-bellied plover. Additional species that were not present on his beach site but are commonly observed feeding in the intertidal beach areas include the least sandpiper, western sandpiper, and dowitcher.

Belding's Savannah sparrows often forage on the dunes, especially when an abundance of kelp has washed ashore. The decaying kelp harbors large numbers of insects, especially flies. At Tijuana Estuary, several sparrows nest in small patches of pickleweed and saltgrass that are surrounded by dunes and dune vegetation (White 1986).

The dunes and beach habitats are dynamic, and recent storm damage has altered the native communities. In order to open the estuary to tidal flushing, the sand that had blown and washed into the estuarine channels was dredged and replaced on the dunes in December 1984. A revegetation program designed to stabilize the dunes and prevent recurrence of mouth closure has been initiated (Jorgensen, pers. comm.; B. Fink, SDSU, in prog.). This program includes transplantation of native species, e.g., primrose, sand verbena, and dune ragweed, and comparisons of survival in areas with and without dune fencing to reduce trampling.

\subsection{RIPARIAN HABITATS}

Riparian vegetation is the plant community that develops along the margins of freshwater streams and lakes, where soils are damp and sandy. Traveling upstream along the Tijuana River towards the eastern boundary of the NERR, one encounters noticeable changes in the vegetation lining the channel, reflecting a gradient of decreasing soil and water salinity. Near the point where the river enters the estuary, salt-tolerant species such as pickleweed and salt grass are abundant in the riparian understory. Further upstream, mulefat scrub, dominated by dense stands of Baccharis glutinosa and sandbar willow (Salix hindsiana), occupies most of the floodplain.
Eventually, the low shrubby vegetation is replaced by magnificent stands of mature riparian forest, characterized by a dense and multi-layered canopy extending from the ground to heights of $15-20$ meters. Here, cottonwoods (Populus fremontii), several species of willows (Salix spp.), and mulefat are among the most common plants. The stretch of the Tijuana River that runs through the reserve is contiguous with one of the longest unfragmented riparian woodlands in San Diego County.

Although less than $10 \%$ of the NERR has riparian vegetation, the value of this habitat type to wildlife is high relative to its acreage. Riparian habitats support more species of birds than any other habitat type in California; over 140 species occur there, 88 of which are obligate riparian species (Faber et al. 1989). For the NERR and the adjacent Tijuana River Valley, a total of 378 species of birds have been recoreded (Jorgensen, pers. comm.).

Birds use riparian habitat for nesting, wintering, or both. The mammalian community is also diverse, with species that dwell primarily in riparian woodlands, such as the long-tailed weasel and bobcat, and species from arid uplands that depend on the availability of water, forage and thermal cover for their survival. Insects are abundant and play important ecological roles as both predators and prey. Many species of fish, reptiles and amphibians occupy riparian habitat and contribute to its unparalleled diversity. According to the Council on Environmental Quality (1978, cited in Faber et al. 1989), "no ecosystem is more essential than the riparian system to the survival of the nation's fish and wildlife."

Part of the reason for the high diversity of the riparian community lies in its structural complexity, which allows for "niche partitioning" among the many organisms seeking food, nest sites, and cover. The presence of tall trees and a dense, luxuriant understory creates a microclimate that differs from that of adjacent upland habitats in its high humidity and cooler temperatures. Insects thrive in this environment, and are an abundant and dependable food source for many 
insectivorous animals. Many animals in upland communities are attracted to riparian woodlands for access to water and shade, particularly during the rainless southern California summers. The riparian zone also serves as a natural corridor linking together adjacent ecosystems and facilitating movement of animals befween them. In these ways, the presence of riparian habitat significantly enriches regional biodiversity beyond what could otherwise be supported.

One of the summer visitors to the Tijuana River is the least Bell's vireo (Vireo bellii pusillus), a small migrant that nests in dense stands of herbaceous and shrubby plants. Once abundant throughout the central valley and other low elevation riverine valleys, the species is now one of California's most endangered birds. Population declines have been precipitous, occurring largely in the last four decades, and have accompanied the loss and degradation of riparian habitat throughout the state. Additionally, brood parasitism by the brown-headed cowbird (Molothrus ater), a species native to the eastern United States, has reduced nesting success to the point that the state's current vireo population consists of only a few hundred pairs (Franzreb 1989). The vireo is now largely confined to San Diego County and northern Baja California.

Least Bell's vireos depart from their wintering grounds in the Cape region of Baja California in early spring, arriving at the Tijuana River in late March. Males establish territories and attract females with their distinctive song: cheedle-cheedle chee? Cheedle-cheedle chew! The pair then constructs a small cup-shaped nest out of leaves and grass, typically placing it about one meter above the ground in dense willow or mulefat vegetation. Females generally lay three to four eggs, which hatch after about two weeks; two weeks later, the nestlings leave the nest and become independent. Vireo pairs may nest up to four times in a season, depending on their success, before departing for wintering grounds in September (Kus 1990b, 1991).

Few riparian plant species are listed as rare or endangered; rather, the entire riparian communily is endangered as a result of human activities including agriculture, flood control projects and channelization, grazing, sand and gravel extraction, road construction, and residential and commercial development. Riparian habitat has been vanishing from the landscape of California at such a pace that today less than 10 percent of the woodlands in existence at the time of the Gold Rush remain, and those are but fragmented remnants. Fortunately, riparian vegetation appears to be resilient and the potential for habitat restoration is high. However, ecologists have much to learn about how natural riparian ecosystems function. Until scientists are convinced that man can restore degraded environments to functioning, self-sustaining ecosystems, protection of existing habitat must be the conservation priority.

\subsection{DYNAMICS OF FEATURED SPECIES}

\subsubsection{Spatial and Temporal Patterns of Habitat Use by Waterbirds.}

Waterbirds, i.e., shorebirds, herons, rails, ducks, pelicans, grebes, gulls and terns, are the most conspicuous animals of the estuarine environment. Valued by the public for the educational and recreational opporlunities they provide, water-associated birds also are a common focus of scientific studies investigating the health, structure and functioning of coastal wetlands.

Perhaps more than any other group of organisms, waterbirds reflect the dynamic nature of the estuarine environment. The large and diverse group of birds using Tijuana Estuary exhibits spatial as well as temporal variability in abundance, distribution, and activity in response to changing physical conditions. Patterns in the bird use of the estuary not only reveal the importance of particular habitats for feeding, roosting, or nesting, but also illustrate the interrelatedness of the various habitat types in their value to wildlife.

The most observable change in the use of Tijuana Estuary by birds is the seasonal variation in species richness and abundance of migratory shorebirds and waterfowl (Table 
3.9). The estuary is a part of the Pacific Flyway used by millions of birds traveling between Arctic and sub-Arctic breeding sites and lower latitude wintering sites. Tijuana Estuary is one of a dwindling number of stopover sites used by migrants to "re-fuel" during their long journey, and it supports large populations of over-wintering birds that depend on intertidal habitats for food.

Recent censuses conducted at Tijuana Estuary (Kus and Ashfield 1989) and throughout the Pacific Flyway (Warnock et al. 1989, Page et al. 1990) have documented that the number of migratory waterbirds at the estuary peaks in the fall, and is an order of magnitude greater than the number present in spring, by which time most birds have departed for the breeding grounds. Only a handful of species nest at Tijuana Estuary during summer.

Seasonal and longer-term differences in abundance are not the only types of temporal variability characterizing the Tijuana estuary waterbird community. Uses change on a diurnal basis, as tidal conditions determine the availability of feeding and resting sites. Kus and Ashfield (1989) conducted regular surveys of the estuary's birds between October and April 1989. In their Iransects, they found that the number of birds was consistently higher during high-tide surveys than during low tides, with the most pronounced differences observed for small and large waders and among the waterfowl (Figure 3.29). This pattern indicated movement between areas in response to changing tidal conditions; during high tides, birds were concentrated at roosting sites within the surveyed areas, while during low tides, birds dispersed to feeding locations within and outside of the census area.

Although Kus and Ashfield could not document the extent to which movement between feeding and roosting areas involved sites outside of the Tijuana Estuary, it is likely that such movement between wetlands is an important determinant of local population size. Moreover, it suggests that regional populations of wetland-dependent birds may be limited by the availability of certain critical habitats found at only a few

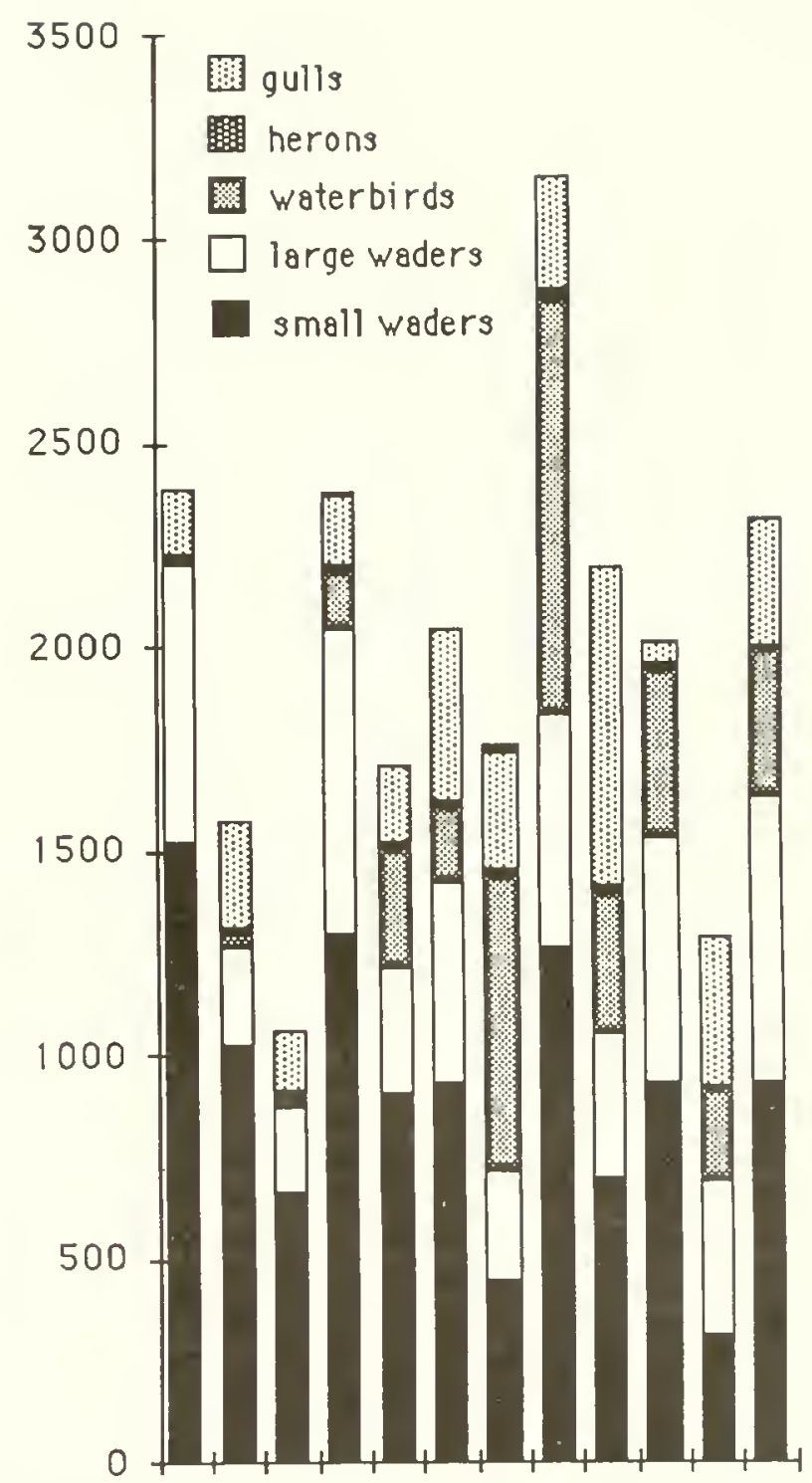

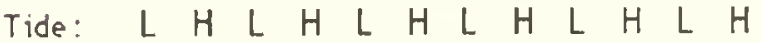
Day: $\quad 714222951220274991524$ Month: October November December

Figure 3.29. Variability in bird use by tidal condition. Data are numbers of individuals observed during low $(\mathrm{L})$ and high $(\mathrm{H})$ tides, by category of bird, showing that both the numbers of birds and the types of birds show temporal variation. Data are from Kus and Ashfield (1989). 
Table 3.8. Waterbird species observed between Oct. and April at the Tijuana Estuary by Kus and Ashfield (1989). Symbol=at least one occurrence per habitat ( $l=i n t e r t i d a l$ flats, $M=$ salt marsh, $\mathrm{B}=$ beach, $\mathrm{S}=$ sandflat, $\mathrm{D}=$ dune); $=$ species also studied by Boland (1981).

\section{Pelicans, Grebes and Cormorants (PEL)}

Waterfowl (WAT)

Small Waders (SW)

Large Waders (LW)

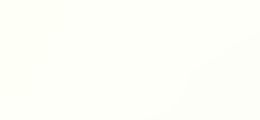

Gulls and Terns (GUL)

Pied-billed grebe

Eared grebe

Western grebe

Double-crested cormorant

Brown pelican

Herons and Egrets (HER)

Sanderling*
Great blue heron

Great egret

Little blue heron

Reddish egret

Snowy egrel

Canada goose

American wigeon

Gadwall

Green-winged teal

Mallard

Northern pintail

Blue-winged teal

Cinnamon teal

Northern shoveler

Lesser scaup

Surt scoter

Common goldeneye

Bufflehead

Red-breasted merganser

Ruddy duck

American coot

Spotted sandpiper

Black-bellied plover*

Killdeer*

Semipalmated plover"

Snowy plover

Ruddy turnstone*

Black furnstone

Least sandpiper*

Red knot*

Western sandpiper*

Dunlin*

Common snipe

Light-footed clapper rail

Black-necked stilt*

American avocet*

Willet*

Yellowlegs species"

Whimbrel"

Long-billed curlew*

Marbled godwit*

Dowitcher*

Bonaparte's gull

Heermann's gull

Ring-billed gull

Mew gull

California gull

Herring gull

Western gull

Caspian tern

Royal tern

Elegant tern

Commontern

Forster's tern

Black skimmer
Podilymbus podiceps

Podiceps nigricollis

Aechmophorus occidentalis

Phalacrocorax auritus

Pelecanus occidentalis

Ardea herodias

Ardea alba

Egretta caerulea

Egretta rufescens

Egretta thula

Branta canadensis

Anas americana

Anas strepera

Anas crecca

Anas platyrhynchos

Anas acuta acuta

Anas discors

Anas cyanoptera

Anas clypeata

Aythya affinis

Melanitta perspicillata

Bucephala clangula

Bucephala albeola

Mergus serrator

Oxyura jamaicensis

Fulica americana

Tringa macularia

Pluvialis squatarola

Charadrius vociferus

Charadrius semipalmatus

Charadrius alexandrinus

Arenaria interpres

Arenaria melanocephala

Calidris minutilla

Calidris canutus

Calidris mauri

Calidris alpina pacifica

Calidris alba

Gallinago gallinago

Rallus longirostris levipes

Himantopus mexicanus

Recurvirostra americana

Catoptrophorus semipalmatus

Tringa spp.

Numenius phaeopus

Numenius americanus

Limosa fedoa

Limnodromus sp.

Larus philadelphia

Larus heermanni

Larus delawarensis

Larus canus

Larus californicus

Larus argentatus

Larus occidentalis

Sterna caspia

Sterna maxima

Sterna elegans

Sterna hirundo

Sterna forsteri

Rynchops niger

I
I
I
I,S
I
I,M
I,M,D
I,M,D
I
I,M,D
I
I,M,D
I
I,M
I
I,M
I
I
I
I
I
I I, I,S,D
I,S,S,D
I,B,S,D
I,S,D
I,S,D
I,M
I,D
I, I,M,B,D
I,


sites, such as high-tide refuges. This question is currently under investigation by Kus.

From the above discussion, it is clear that many waterbirds are not confined to particular habitat types, but rather use a mosaic of habitats for feeding, roosting and nesting. Spatial variation in waterbird distribution is a function of abiotic factors, such as tidal conditions, as well as biotic factors, including competition and predation. Species that typically occur at Tijuana Estuary differ in the extent to which such factors influence their distribution. For example, Kus and Ashfield found that pelicans, grebes, cormorants and most waterfowl species were restricted to intertidal flats and channels, while most gulls, terns, and herons used several habitat types (Table 3.8 ).

Both Boland (1981) and Kus and Ashfield (1989; Table 3.8) observed shorebirds in a wide variety of habitats, and noted that with the exception of the common snipe, every species they studied occurred in intertidal areas. Although many shorebird species used several different habitats, the distribution of individuals was not uniform across all habitat types. Boland (1981) consistently found the highest densities of all but the sanderling in intertidal flats and channels; likewise, Kus and Ashfield (1989) observed that the majority of large and small waders seen during low-tide surveys occurred in those habitats (Figure 3.30).

Kus and Ashfield also noted that the distribution of birds across habitat types varied as a function of tidally-mediated movement between habitats. Small waders lypically occurred in large numbers in the sandy dune habitat during high tides, moving to the intertidal areas to feed during low tides (Figure 3.31). Large waders exhibited a similar, but less dramatic, shift between habitats (Figure 3.32). Proportionately more large waders than small waders remained in intertidal areas during high tides, probably because their larger size and longer legs enabled them to do so.

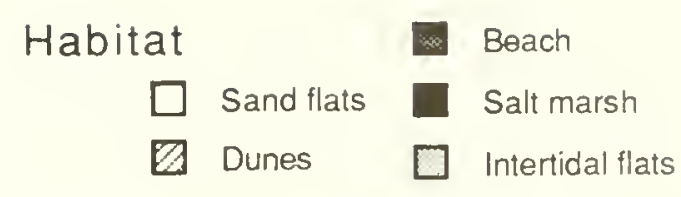

Small Waders

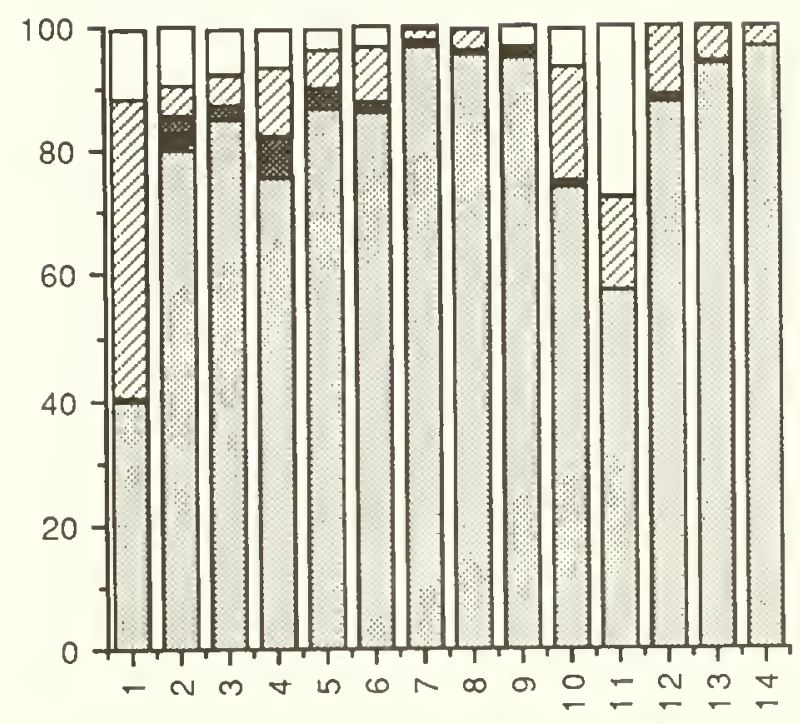

Large Waders

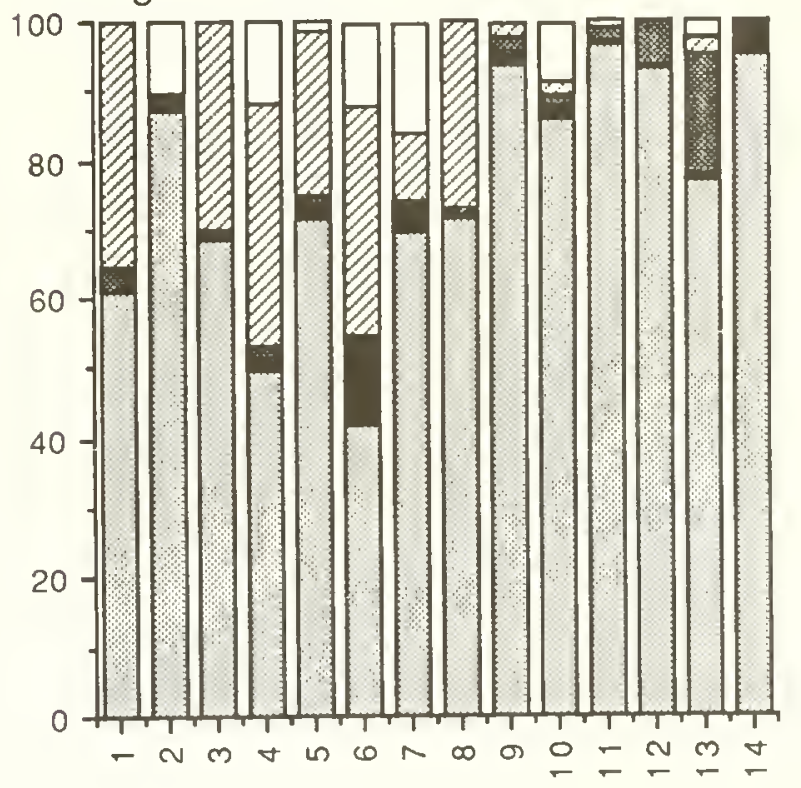

Figure 3.30. Percent of all individuals seen in each of five habitat types during low tide surveys. Sample dates ( $x$ axis) are biweekly beginning October 7 and ending April 8 , 1988 . 

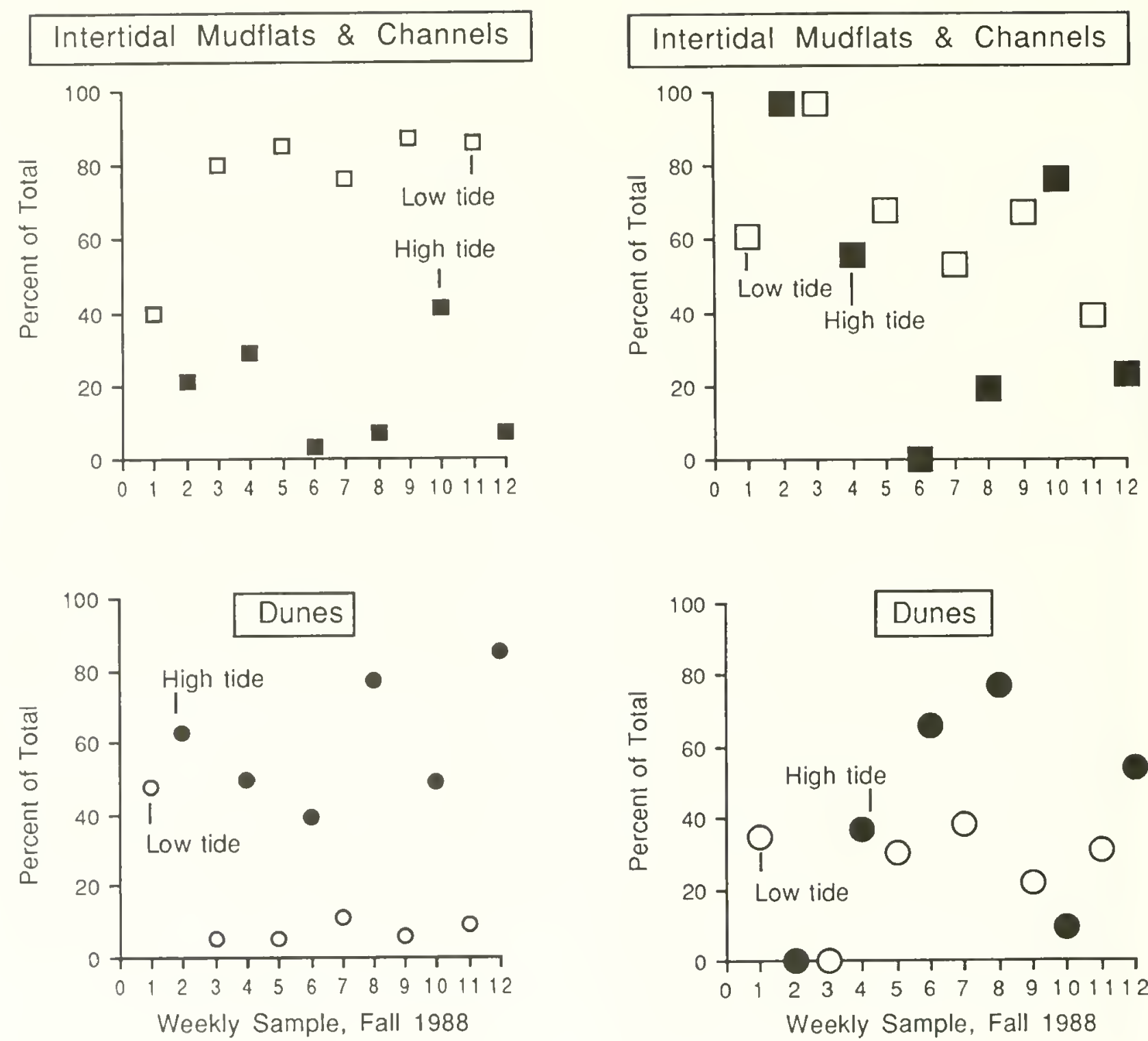

Figure 3.31. Percent of all small waders seen in intertidal flats and channels (top) and dunes (bottom) during high and low tide surveys.

Waterbirds at Tijuana Estuary interact with each other and their environment in ways that are dynamic and complex. The ability of individuals to exploit a variety of habitats that change daily, seasonally, and annually makes the estuarine bird community one of the most diverse in nature. At the same lime, the behaviors that allow waterbirds to respond to change also make them

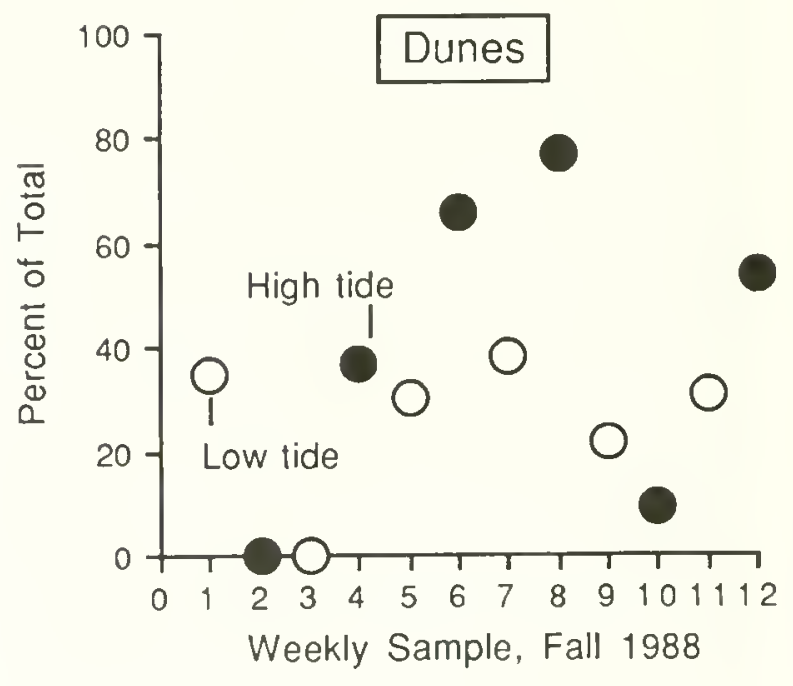

Figure 3.32. Percent of all large waders seen in intertidal flats and channels (top) and dunes (bottom) during high and low tide surveys.

particularly vulnerable to human activities that disturb the network of habitats upon which they depend. Globally, the loss of wetlands eliminates links in a fragile chain of migratory staging and stopover sites that tie together breeding and wintering grounds, threatening entire populations and even species. Regionally, alteration of wetland habitat restricts movement within and 
between sites in response to changing physical conditions, and eliminates critical feeding and roosting sites used by wintering birds. Human encroachment on the estuarine environment introduces predators and other sources of disturbance from which waterbirds have no refuge. Clearly, the survival of Tijuana Estuary's many rare species (Table 3.10) depends on protecting the integrity and extent of coastal habitats.

Table 3.10. Sensitive species of the wetlands at Tijuana Estuary.

Plants

Cordylanthus maritimus ssp. maritimus (Salt marsh bird's beak) FE,SE Invertebrates

Coelus globosus (Globose dune beetle)

Panoquino panoquinoides (Salt marsh wandering skipper)

$\mathrm{C} 2$

Brennania belkini (Belkin's dune fly)

Cicindela hirticolis gravida (Sandy beach tiger beetle)

C. latesignata latesignata (Sand dune tiger beetle)

C. trifasciata sigmoidia (Mudflat tiger beetle)

C. gabbi (Gabb's tiger beetle)

$\mathrm{CSC}$

\section{Reptiles}

Phrynosoma coronatum blainvillei (San Diego Horned Lizard)

Anniella pulchra pulchra (Silvery legless lizard)

$\mathrm{CSC}$

\section{Birds}

Pelicanus occidentalis (California brown pelican)

FE,SE

Egretta rufescens (Reddish egret)

Circus cyaneus (Northern harrier)

$\mathrm{C} 2$

Aquila chrysaetos (Golden eagle)

Falco peregrinus anatum (American peregrine falcon)

Rallus longirostrus levipes (Light-footed clapper rail)

Sterna antillarum browni (California least tern)

$\mathrm{CSC}$

CSC

Charadrius alexandrinus nivosus (Western snowy plover)

FE, SE

Numenius americanus (Long-billed curlew)

Vireo bellii pusillus (Least Bell's vireo)

FE

FE,SE

FPT, CSC

$\mathrm{C} 2$

FE,SE

Dendroica petechia brewsteri (Yellow warbler)

CSC

CSC

Icteria virens (Yellow-breasted chat)

Ammodramus sandwichensis beldingi (Belding's Savannah sparrow)

$\mathrm{C} 2, \mathrm{SE}$

A. S. rostratus (Large-billed Savannah sparrow)

$\mathrm{C} 2$

\section{Key 10 status}

$\mathrm{FE}=$ Federally endangered species

$\mathrm{SE}=$ State endangered species

$\mathrm{C} 2$ = Category 2 candidate species for listing. These are species for which existing information indicates they may warrant listing, but for which substantial biological information to support a proposed rule is lacking. 


\subsubsection{Species of Special Concern}

Tijuana Estuary provides habitat for some 24 rare, threatened or endangered species (Table 3.9). Without exception, these species have undergone precipitous declines in recent decades because of the loss and degradation of wetland habitat. The occurrence of these plants and animals at Tijuana Estuary bears testimony to the role that the estuary plays in protecting regional and global biodiversity.

Many of the sensitive species at the estuary are monitored by the U.S. Fish and Wildlife Service and other biologists, and a few are targets of research in wetland restoration. The following sections summarize the status of selected species.

\section{Belding's Savannah Sparrow}

(Ammodramus sandwichensis beldingi)

The population of Belding's Savannah sparrows at Tijuana Estuary has grown steadily since surveys were initiated in the mid-1980's. In 1985, 81 pairs nested in the middle marsh areas north of the Tijuana River (White 1986). Censuses in 1973 and 1977 indicated that there were 100 and 95 nesting pairs, respectively, throughout the entire estuary, including the previously unsurveyed marsh south of the river. By 1986, the population had grown to 225 pairs (Zembal et al. 1988). Kus and Ashfield (1989) report that between 299 and 320 pairs occurred throughout the estuary in the spring of 1989; the population underwent further increase during the following year and was estimated at between 289 and 397 pairs in 1990 (Kus 1990a). Much of the population growth in recent years is the result of expansion into the salt marsh in the southwestern portion of the estuary.

Data collected during statewide censuses of Belding's Savannah sparrows reveal that Tijuana Estuary supports at least 10 percent of the state's population (Massey 1979; Zembal et al. 1988). Only 3 of the 31 wetlands surveyed in the last statewide effort (1986) supported larger populations.
California Leasi Tern

(Sterna antillarum browni)

The number of nesting pairs of least terns at Tijuana Estuary fluctuates widely from year to year, as at other nest sites that are unprolected from predation and human disturbance. Adult terns breeding for the first time do not show a clear preference for their natal colonies but tend to return to a site once they have bred (Massey and Atwood 1984). Estimates of the number of nesting pairs have ranged from 21 10 72 in the past 10 years (Table 3.10 ), with population trends at the estuary paralleling those seen in the statewide population (E. Copper, pers. comm.).

Factors such as winter mortality have not been examined but could help to explain annual variations in tern numbers. The 1984 closure of Tijuana Estuary to tidal flushing may have adversely affected recruitment. In 1984, about 50 pairs nested but no fledglings were observed. The stagnant channel water and corresponding reduction in fish and invertebrate populations may have contributed to nesting failure ( $E$. Copper, pers. comm.).

Table 3.10. California least tern nesting data, 1982-1991 (from Least Tern Recovery Team, unpubl., E. Copper, unpubl., and Patton 1991). Prs $=$ pairs.

\begin{tabular}{|c|c|c|c|}
\hline \multirow[b]{2}{*}{ Yr } & \multicolumn{2}{|c|}{ Tijuana Estuary } & \multirow{2}{*}{$\begin{array}{l}\text { California } \\
\text { Nesting Prs }\end{array}$} \\
\hline & Nesting Prs & Fledglings & \\
\hline ' 82 & $21-30$ & 17 & $1015-1245$ \\
\hline 83 & $60-65$ & $50+$ & $1196-1321$ \\
\hline ' 84 & 66 & $12-20$ & $931-1002$ \\
\hline ' 85 & 32 & $18-20$ & $1100-1112$ \\
\hline ' 86 & $36-41$ & $25-40$ & $906-1015$ \\
\hline ' 87 & 21 & $13-19$ & $923-947$ \\
\hline ' 88 & 34.48 & 29.35 & 1253 \\
\hline ' 89 & 49 & $23-31$ & 1236 \\
\hline 90 & 72 & $13-39$ & 1700 \\
\hline ' 91 & 64 & $22-32$ & 1800 \\
\hline
\end{tabular}


Western Snowy Plover

(Charadrius alexandrinus nivosus)

While less well studied than the least tern colonies, the snowy plover breeding population at Tijuana Esluary is observed annually during least tern censusing (Copper, pers. comm.). In addition, periodic statewide surveys are conducted by Point Reyes Bird Observatory biologists, who have been studying this species throughout the western U.S. and Baja California for nearly 2 decades. Both sources of information reveal that the snowy plover population at the estuary has undergone a significant decline, reflecting the downward trend in the entire coastal population that prompted the recent proposal for Federal listing. In 1978, biologists counted 37 adult snowy plovers at the mouth of the Tijuana River; a decade later, the population was down to 21 adults, and by 1991, only 4 adults were counted during the spring survey (Page and Stenzel 1981, Page et al. 1991). E. Copper (pers. comm.) reports that while approximately 100 nesting pairs were typically seen nesting on beaches and in the dunes north and south of the river mouth, in 1990 only 10 pairs were observed.

\section{Least Bell's Vireo}

(Vireo bellii pusillus)

The least Bell's vireo, one of four subspecies of Bell's vireo occurring in the U.S., is a state and federally endangered species. Although historically vireos occupied habitat along the length of the Tijuana River, the nesting population was reduced to 5 pairs by 1986, including a single pair within the boundaries of the refuge (RECON 1988). Since that time, the population has made a steady comeback, increasing to 9 pairs and 4 unpaired males in 1990 (Kus 1990b), and then nearly doubling to 15 pairs and 8 unpaired males in 1991 (Kus 1991). Most of the population expansion has occurred west of Hollister Streel towards the estuary. Currently, the Tijuana River vireo population is the fifth largest in San Diego county.

The increase in the vireo population at the Tijuana River is in part the result of an effective cowbird removal program implemented in recent years. Parasitism of vireo nests has been virtually eliminated since 1990, and nesting success has been consistently high (Kus 1990b; 1991). With proper management, the Tijuana River has the potential to support one of the largest vireo populations in California, making it a critical site in efforts to promote the recovery of this endangered bird.

Studies of individually recognizable colorbanded vireos indicate that part of the breeding population at the Tijuana River consists of dispersers from natal sites at the Sweetwater and San Diego Rivers (Kus 1990b, 1991). The Tijuana River has also been documented as a stopover site used by migrating vireos (Kus 1990b), and may be an important link in the chain of riparian woodlands connecting southern California with the vireo's wintering grounds in Baja California.

The salt marsh bird's beak

Cordylanthus maritimus s sp. maritimus)

Salt marsh bird's beak is endangered with extinction. Only 5 of its 12 historic sites still support the species. Tijuana Estuary has several colonies that reappear in most years, but densities and seed production are highly variable. Among the more puzzling attributes is the occasional failure of a colony to germinate, with reappearance after a year or two. The timing and amount of spring rainfall are possible controls.

This endangered hemiparasitic annual plant has been the subject of studies of its ecological requirements and potential for restoring historic populations (Fink and Zedler 1989). Following field and laboratory experimentation, seed from Tijuana River National Wildlife Refuge (NWR) was sown at the nearby Sweetwater Marsh NWR (along San Diego Bay) in 1991. Several patches grew and reproduced (PERL, sludies in progress), indicating potential for reestablishment of a viable population. However, it is doubtful that the number of seeds produced was as great as the number planted (B. Fink, pers. comm.). 
The salt marsh bird's beak is a generalist in its host preferences but a specialist in its habitat requirements. It is not host specific. Brian Fink (Fink and Zedler 1989) was able to culture it with Distichlis spicata, Monanthochloe littoralis, Salicornia virginica, Frankenia grandifolia, S. subterminalis, and Atriplex watsonii, with growth (biomass) of the parasite declining in that order. Plants accumulated more than $7 x$ the biomass with Distichlis than with Atriplex watsonii. Fink was also able to culture it alone, suggesting that it is a facultative parasite. However, it is more likely to survive without a host in the laboratory, where it is watered, than in the field, where soils become very saline and occasionally desiccated in early summer. Experimentation with and without host plants and with and without salt added to the soil showed significant differences. Plants were more salt tolerant if grown with a host plant (Fink and Zedler 1989).

Although not host specific, the species is habitat specific. It occurs in the upper salt marsh in partially shaded areas that have reduced soil salinity in spring and that do not impound water for more than 24 hours. Tests of its shade tolerance (ibid.) indicated peak growth with $20 \%$ shade and significantly less biomass at both $73 \%$ and $0 \%$ shade. Reduced salinities increase seed germination ( $\mathrm{J}$. Newman, U.S. Navy, Point Mugu, unpubl. data). Seedlngs are sensitive to inundation, however, even if the water is nonsaline ( $B$. Fink, PERL, pers. comm.). Thus, deep depressions are not optimal habitats, a series of rains can form pools that persist long enough to kill plants.

Flowering, pollination, and seed set are all essential for long-term persistence. That the seed bank can persist for at least a few years is indicated by patches that reappear after a year or two and by germination of seeds that have been stored for no more than 9 years ( $B$. Fink, pers. comm.). Flower numbers correlate well with plant biomass $(R=0.8$, Fink and Zedler 1989), so plants that grow larger tend to allocate more resources to reproduction. Pollination success is not assured, though. Not all the patches that were planted at Sweetwater Marsh produced seed.
The larger patches produced more seed, suggesting that the limiting factor is the ability to attract suitable pollinators. According to Lincoln (1985) the usual pollinators are solitary bees that nest in burrows in the upland. Many of these peripheral habilats have been developed, further restricting the potential for preserving the endangered bird's beak. Pollinators have not been studied at either Sweetwater Marsh or Tijuana Estuary, but there is a clear need to understand the linkage between the upland bees and the few species of salt marsh plants that are not windpollinated.

The light-footed clapper rail (Rallus longirostris levipes)

Because the light-footed clapper rail is endangered with extinction, the U.S. Fish and Wildlife Service monitors its abundance throughout the region. In 1991, 34 marshes were censused and birds were found in 11. A total of 235 pairs were censused in the region, with Upper Newport Bay having the largest number (128 pairs) and Tijuana Estuary "in second place " (47 pairs; Zembal 1991). In other words, $20 \%$ of the region's population occurred at this estuary in 1991. The 1991 census was a new record for Tijuana Estuary. The previous peak population density occurred in 1983 (41 pairs), when cordgrass vegetation was luxuriant (Chapter 5).

The regional population of light-footed clapper rails has flucluated considerably (Figure 3.31), with a noticeable drop in 1985. Part of the reason for that decline was the 1984 nontidal period at Tijuana Estuary. Before 1985, the population fluctuated belween 25 and 41 breeding pairs (Jorgensen 1975; Zembal and Massey 1981a,b). In 1983, Tijuana Estuary supported $17 \%$ of the State's 249 breeding birds. Then, the estuarine mouth closed in April 1984, and no rails were seen in the March-April census of 1985. Recorded bird calls were also used to locate territorial pairs, but none was indicated. The 1984 extinction of the Tijuana Estuary population was probably due to a 

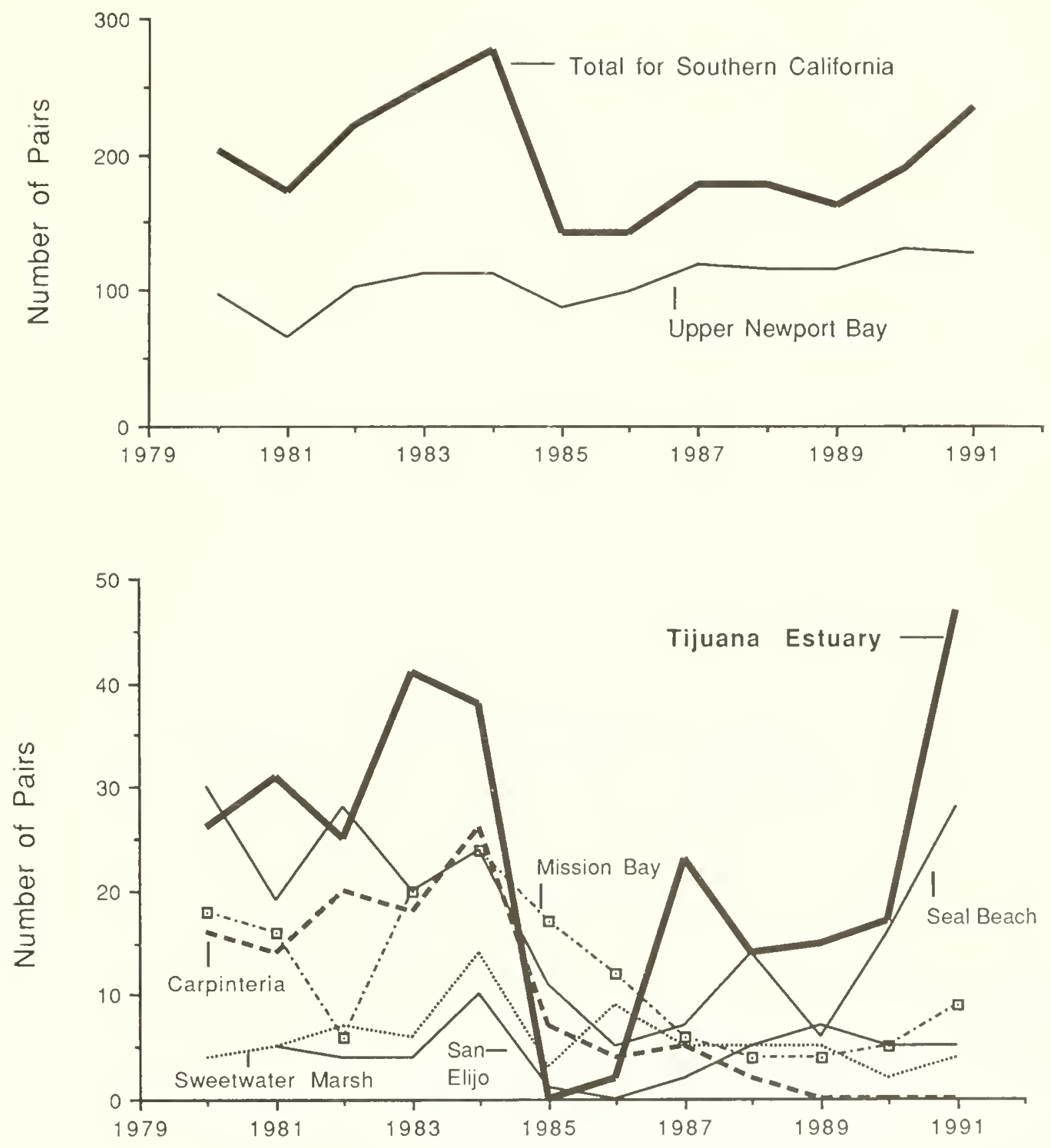

Figure 3.31. Dynamics of the light-footed clapper rail population in southern California. The largest number of nesting pairs occurs at Upper Newport Bay (top graph); Tijuana Estuary now ranks second in the region (bottom graph). Data are numbers of pairs in censuses reported by Zembal (1991). 
combination of stresses: reduced food supplies, poor cover, and lack of predator protection.

Light-footed clapper rails are considered to be generalists in terms of feeding, but direct observation and dissection of regurgitated pellets shows that the majority of foods come from channel and tidal creek habitats: marine decapods, isopods, snails, crabs, fishes, and some insects and spiders (Massey and Zembal 1979). With the 1984 drought, invertebrate populations declined, rails had few prey available, and starvation is a likely cause of bird mortality. Declining cover during the nesting season may have led to nesting failure by reducing the area of dense cordgrass for nest construction and by making nests and birds more visible to predators. Finally, the absence of tidal flushing greatly reduced protection from predators. Few mammals frequent habitats where tides saturate the soils twice a day, but in summer and fall 1984, there were few natural deterrents to terrestrial predators. Birds that had little cover and low food supplies would no doubt have been highly susceptible to predation; chicks would have been easy prey for dogs, cats, and raptors.

The population crash at Tijuana Estuary was not permanent, but it did not recover immediately after dredging restored tidal flushing (in December 1984). The birds reestablished on their own, but it is not clear where they came from. The population increased from 2 pairs in 1986 to the 1991 peak of 47 pairs. Recovery was not steady, as the 1987 high count of 23 pairs was followed by $61 \%$ drop to 14 in 1988 . It is too soon to tell whether the population will stabilize or what level constitutes the carrying capacity of the system. Active management to maintain tidal flow is necessary but apparently not sufficient.

The decline of the entire southern California population from 277 pairs in 1984 to 142 pairs in 1985 is only partly explained (i.e., $20 \%$ ) by tidal closure at Tijuana Estuary. There were heavy losses in other wetlands that remained open to tidal flushing (Zembal 1991, Figure 3.31). It is likely that most of the region's clapper rails were reduced by mortality, rather than emigration, as alternative habitats are few and far from the coastal wetlands. The birds are found in the marshes of Estero de Punta Banda near Ensenada, Mexico. Habitat has also declined at this wetland, with a large part of the bay being dredged for construction of an oil-platform factory.

The future of the light-footed clapper rail is uncertain. With such a large fraction of the population at one site $(54 \%$ at Upper Newport Bay), a major flood or predator invasion (e.g., red fox) there could have devastating impacts regionwide. The subpopulation at Tijuana Estuary offers a unique opportunity for enhancement first because it is fairly large and may retain significant genetic diversity, and second because there is ample room for restoration of its preferred habitat, cordgrass and tidal creeks. The tidal restoration plan (cf. Chapter 6) could open hundreds of acres of nearby, relatively dry habitat to clapper rails. The greatest potential for increasing clapper rail numbers is to increase the area of suitable habitat at sites that already have rails present and that are managed to sustain tidal flows. Tijuana Estuary has the most potential for such enhancement. 


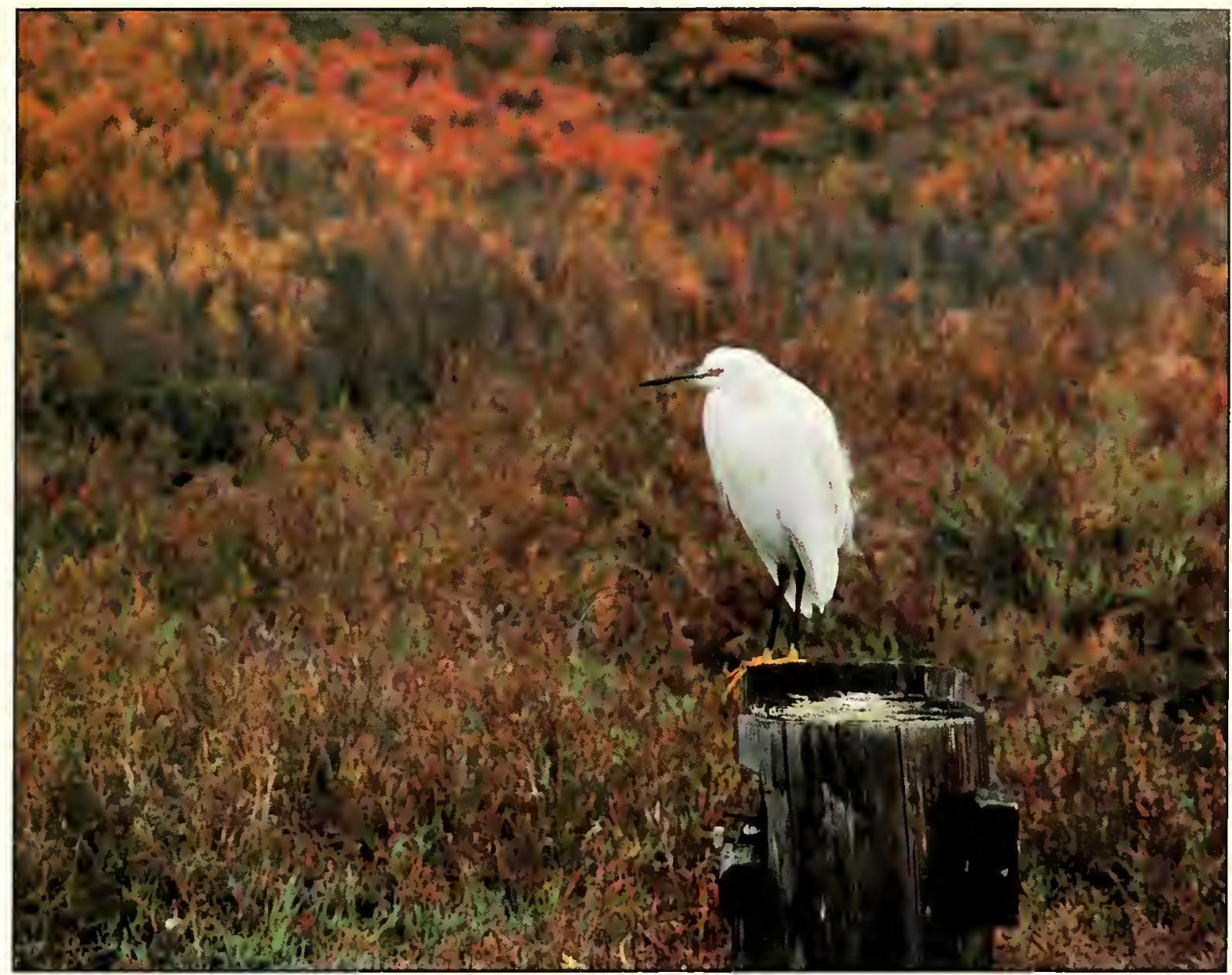

snowy egret, (c) 1992 by Juliette Murguia

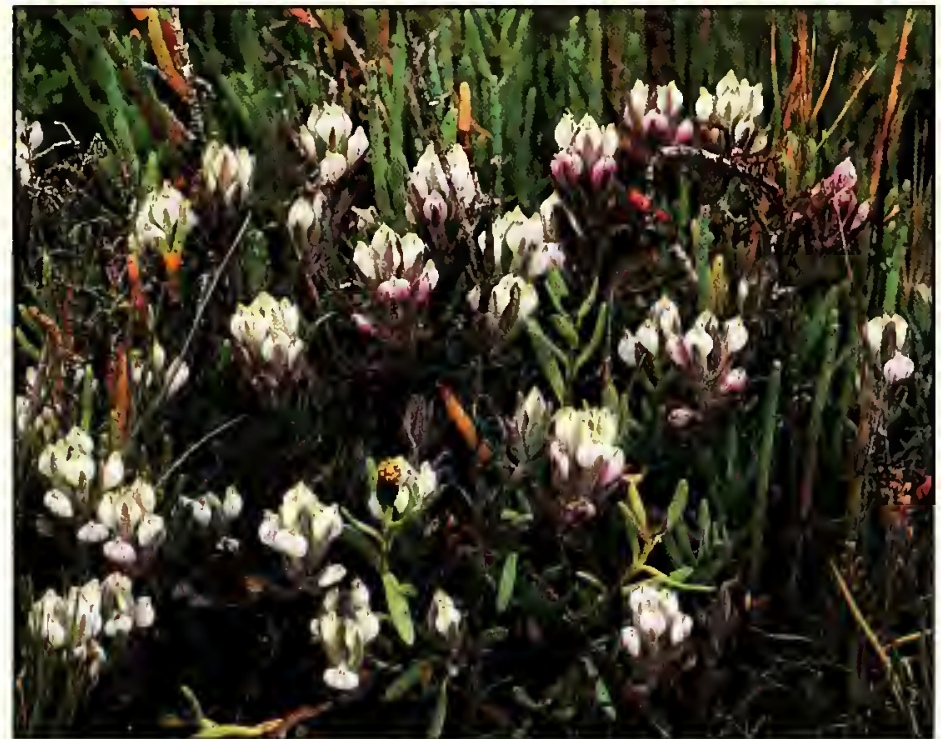

salt marsh bird's beak, (C) by Phillip Roullard

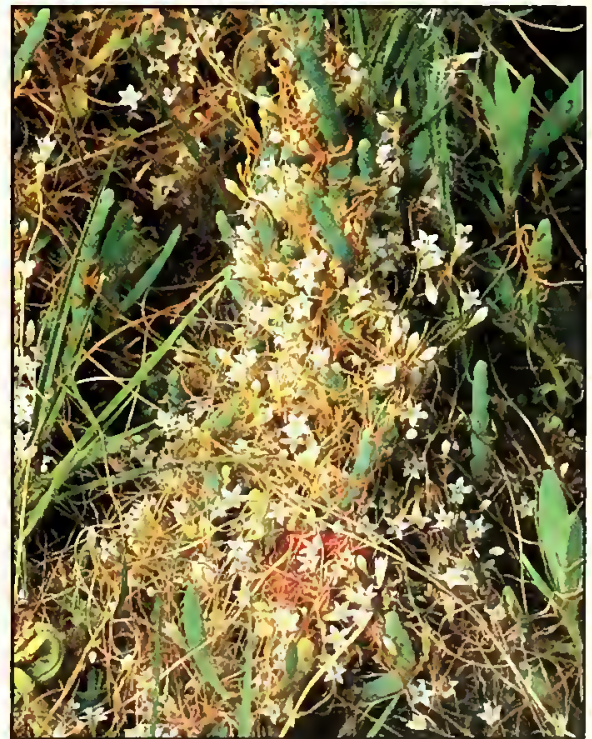

dodder, by Pat Flanagan 

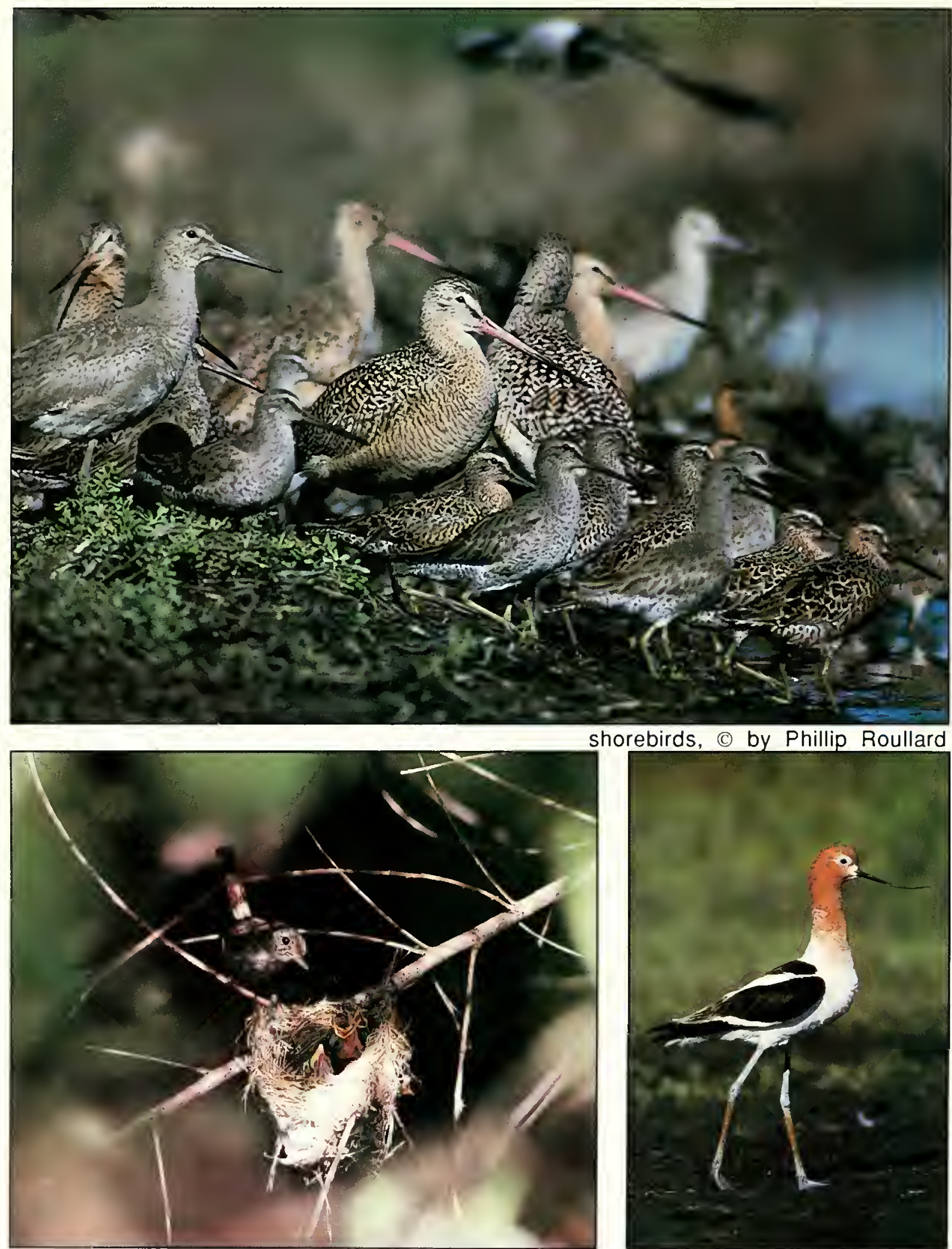

shorebirds, (c) by Phillip Roullard

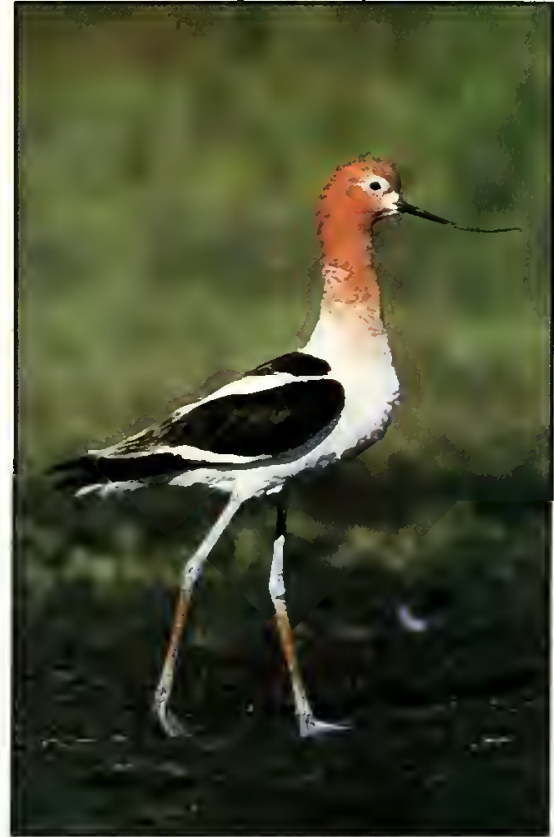

avocet, (c) by Phillip Roullard 


\section{CHAPTER 4}

\section{ECOSYSTEM FUNCTIONING}

Studies of energy flow and nutrient cycling in the salt marsh were initiated in 1976 , when researchers began to test the "East Coast dogma" about coastal wetlands. Research on the extensive coastal plain marshes in Georgia and elsewhere had indicated extremely high rates of vascular plant productivity, which in turn subsidized coastal food chains. The early work in southern California indicated that salt marshes were indeed different, with rates of primary productivity lower for vascular plants and higher for epibenthic algae underneath the open canopy (Sections 4.24.3). Functional models of the ecosystem were not developed, because the system simply was not stable long enough for energy flow rates to be characterized. Later work focused on short-term growth rates in response to variations in specific environmental factors. For example, studies of the algal growth in channels were initiated in 1984, when problems of sewage spills and threats of year-round wastewater discharges indicated the need to understand what triggers nuisance algal blooms. Our ability to characterize ecosystem functioning has thus been limited by variability. On the other hand, our understanding of species composition (Chapter 5) has been aided by witnessing responses to environmental fluctuations.

\subsection{PRIMARY PRODUCTIVITY OF CHANNEL ALGAE}

The research of Rudnicki (1986) and Fong (1986) characterized temporal patterns of algal abundance in five habitats at Tijuana Estuary, and manipulative experiments have shown how algae respond to different salinities and nutrient inputs. Throughout this section, the observations on macroalgae are based on Rudnicki's work, and information on phytoplankton is based on Fong's research. The term macroalgae generally refers to Enteromorpha and/or Ulva, as these genera are not always easy to distinguish. As used here, phytoplankton includes all microscopic algae suspended in the water column, whether derived from the channel sediments or continuously planktonic (free-floating).

Chlorophyll concentrations and cell counts, rather than changes in productivity rates, have been used to measure responses to nutrient influxes. Maximum concentrations of chlorophyll in the plankton occurred during the 1984 nontidal episode, when Fong documented a bloom of unicellular bluegreens (Table 4.1). On the other hand, maximum populations of macroalgae may have occurred during the winters of 1983 and 1984 when tidal flushing was sluggish and nutrient concentrations were high due to sewage spills. However, our only evidence of this is the March 1984 air photo, which shows substantial macroalgal growth along the shores of the inland lagoons and within the northern tidal creeks. After tidal flushing was reinstated, neither algal type developed blooms of nuisance proportions.

Rudnicki and Fong's joint monitoring program began in 1985 and provided monthly data on the seasonal dynamics of channel algae (Figure 4.1). Three tidal creeks, the dredged channel, and the inland lagoons were sampled for phytoplankton, by collecting water samples to measure chlorophyll concentration and count cells. The same sites were sampled simultaneously for macroalgae by determining their cover and maximum biomass. Macroalgae germinate and develop on the sediments under shallow water. At some later 

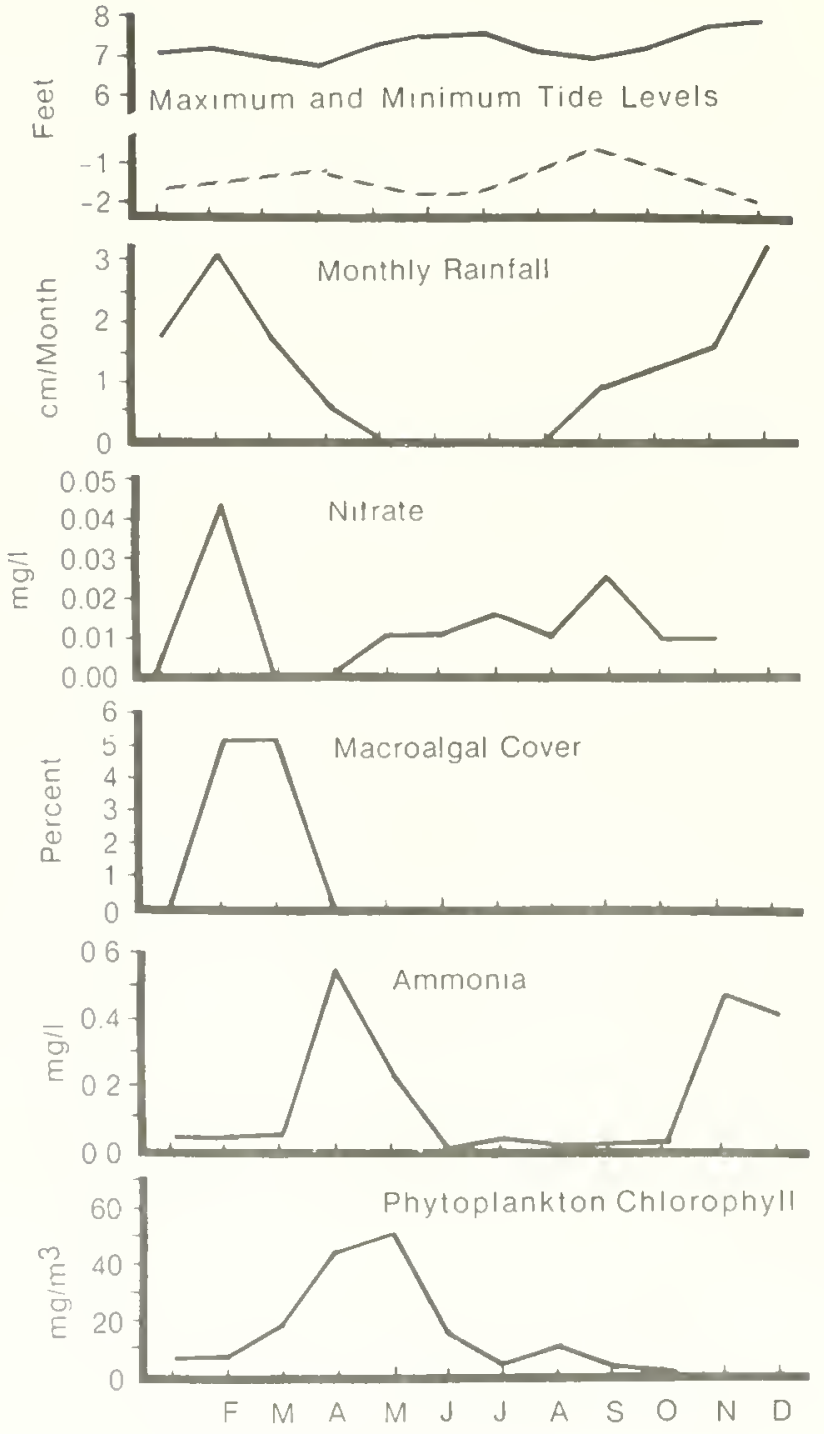

Figure 4.1. Seasonal dynamics in channels and creeks sampled monthly during 1985. Data for nutrient concentrations and algal abundance are presented in order of the time of their maximum value. Phytoplankton data are from a tidal creek; all data are from Fong (1986) and Rudnicki (1986). stage, the algae may be dislodged, float to the surface, and be moved about by wind and water currents. As a result, cover can be highly variable in both space and time, and areas of similar cover can have very different biomass. The field survey was devised to identify conditions that led to maximum biomass (called blooms); thus, areas with the greatest volume of algae were sampled at each monitcring station.

Of the five habitats sampled, phytoplankton were most dense in the tidal creek that had the lowest tidal circulation. Seasonal peaks in chlorophyll and cell counts occurred in spring when weather was warm and tidal action minimal. Together, the 1984 observations of blooms during closure and the 1985 field study suggested that phytoplankton accumulate when water currents are reduced and when nutrients are plentiful (Table 4.1). At other times, tides continually remove algae and maintain clearer water.

Table 4.1. Water quality at Tijuana Estuary during nontidal (1984) and tidal conditions (summary data from Fong 1986 and Rudnicki 1986).

Data

Nontidal Tidal

Temperature ${ }^{\circ} \mathrm{C}$

Salinity ppt

Dissolved oxygen ppm

$\%$ cover of macroalgae

Chlorophyll a $\mathrm{mg} / \mathrm{m}^{3}$

Phytoplankton cells $/ \mathrm{ml}$

14

18

$13 \quad 34$

$\begin{array}{ll}4.4 & 7.7\end{array}$

0

147

5

Extinction coefficient

$2,000,000$

15,000

Total Kjeldahl nitrogen ppm

31

4.4

2.5

1.0

Ammonium ppm

$0.05 \quad 0.02$

Nitrate ppm

0.007

1.7

0.010

Total phosphorus ppm

Phosphate ppm

0.88

0.1

0.02 
Macroalgal growth patterns were more variable. During 1985, the cover of floating macroalgae never reached nuisance levels, i.e., the water column did not become anoxic and there were no fish kills. Maximum standing crops averaged only $15 \mathrm{~g} / \mathrm{m}^{2}$ ( $\mathrm{n}=$ 12), with a range from 0-185. Highest values lended to occur in the inland lagoon. This does not necessarily mean that productivity was highest there, because macroalgae are relocated by the prevailing onshore winds.

Rudnicki determined that several factors act together to increase macroalgal biomass in estuarine channels. Algal establishment coincided with daytime low tides, which occur primarily in winter and early spring. Germination mainly occurred along the shallow edge of creeks and channels where current speeds and light levels were suitable. Following establishment, growth was stimulated by nutrient inputs from rain and runoff and by afternoon exposure. When the cold tidal water receded, algae became warmer and received more light. However, macroalgae biomass did not necessarily accumulate in all areas of high productivity. Maximum volumes of macroalgae developed under two conditions, where circulation was reduced and where prevailing winds moved the floating mats. Neither Enteromorpha nor phytoplankton reached peak densities in well-flushed channels. Any current strong enough to scour the macroalgae would certainly limit the accumulation of phytoplankton as well.

The conditions that stimulate macroalgal growth were further researched by Mary Kentula (unpubl. data) in the salt marsh of Mission Bay $(25 \mathrm{~km}$ north of Tijuana Estuary). In winter, she collected Enteromorpha-dominated algal mats from soils beneath cordgrass and measured their light-saturation points. Under a broad range of temperatures $\left(17-33^{\circ} \mathrm{C}\right)$, the mats became saturated at $400-600 \mu$ Einsteins $/ \mathrm{m}^{2} / \mathrm{s}$. By comparison, photosynthesis of the summer algal mats (dominated by blue-green algae and by mixtures of blue-greens and diatoms) were not light-saturated until exposed to 900 $\mu E / m^{2} / s$. Comparing the two types of algal mats under high light and temperature, the summer community was $30 \%$ more productive than Enteromorpha. As space and nutrients become limiting in spring and early summer, blue-green algal mals would have the competitive advantage. Furthermore, Rudnicki found that Enteromorpha deteriorated rapidly in warm, drying field conditions, as there is no resistance to desiccation. Winter conditions thus favor growth of this green alga over the species that dominate in summer.

Rudnicki (1986) and Fong (1986) tested the role of environmental conditions in stimulating algal blooms by exposing known mixtures of phytoplankton and macroalgae to three salinities $(10,20$, and $34 \mathrm{ppt})$ and three levels of fertilization (Milorganite, a dried sewage-sludge product, was added in high, low, and zero levels). They devised a floating rack with 27 15-liter microcosms anchored in one of the estuary's tidal creeks; they then followed algal growth weekly for a month. Separate experiments were set up: (1) in winter 1985 using Enteromorpha sp. and the monad-dominated plankton, (2) in spring 1985 with Enteromorpha and a dinoflagellate-dominated plankton community; and (3) in fall 1985 with phytoplankton only, because macroalgae were rare in the estuarine channels.

In these experiments (Figure 4.2), phytoplankton responded rapidly to nutrient addition, with biomass increasing substantially after 1-2 weeks. Macroalgae look somewhat longer to reach maximum biomass. Blooms of Enteromorpha developed in the third week. It is likely that interactions between these two groups of producers occurred, through competition for nutrients and/or light. The high nutrient treatments of the summer experiment, which lacked macroalgae, were consistently larger than the winter and spring experiments, which had both Enteromorpha and phytoplankton. Competitive interactions were later demonstrated experimentally by Fong (1991), who found phytoplankton blooms where macroalgae were absent.

Salinity affected the growth of both phytoplankton and macroalgae. Lowered salinity delayed phytoplankton blooms, and the 
species composition of the bloom differed in low-salinity treatments. Blue-greens dominated at $10 \mathrm{ppt}$, just as they had dominated the stagnant channels in April-June 1984 when brackish water (12-15 ppt) was impounded. Enteromorpha grew best at 33 ppt. It survived $10 \mathrm{ppt}$ best where nutrient concentrations were high.

The changes in channel algae at Tijuana Estuary are well explained by the experimental results (Table 4.2). Nutrient additions maximize biomass of both primary producer components, but current speeds and temperature have differential effects. Thus, in years of good tidal flushing and fewer sewage spills (i.e., through the 1970's), neither type of algae was likely to develop bloom conditions because of continual dilution and export. With more frequent and larger sewage spills, blooms became possible. When currents became sluggish following the 1983 winter storm, macroalgae were able to accumulate in the nutrient-rich, quiet waters of the estuary, but phytoplankton were still prevented from developing high densities. Then, with no tidal flushing in 1984, phytoplankion densities reached nuisance proportions, while warm water, hypersalinity (60 ppt), and possibly competition for nutrients and light limitation at the channel bottom, reduced establishment and growth of Enteromorpha. Further refinement of this conceptual model of algal dynamics is in progress, with experiments varying salinity, nitrogen, and phosphorus concentrations planned for 1986.

\subsection{PRODUCTIVITY OF EPIBENTHIC ALGAL MATS}

Epibenthic algal mats are characteristic of the salt marsh, although the community is frequently supplemented by species entrained from the channels. For example, Enteromorpha extends into the lower salt marsh in winter and spring. Likewise, some salt marsh algae extend into the channels. Filamentous blue-green algae develop patches in the lidal creeks during summer. Thus, there is an overlap in species composition. The salt marsh algae comprise a matrix or mat of filaments and associated unicells that is usually bound to the substrate. The algae that float in channels are usually the fronds of one or two green macroalgae.

Dense algal mats are often found beneath the canopy of salt marsh vegetation. Biweekly field measurements in 1977 suggested that their annual productivity could match or exceed that of the vascular plants (Table 4.3). The highest productivity rates were measured in the most open canopies of frequently inundated areas during the warm season. The lowest rates were measured in winter in areas where moisture was limiting. In 1977, the lowest productivity occurred in April when there was little rainfall and neap tides did not inundate the higher marsh. A hypothesis was developed (Zedler 1980, 1982b) that the saline soils reduced vascular plant biomass, thereby increasing sunlight availability and algal productivity on the soil surface.

Kentula (unpubl. data) tested the model of algal-vascular plant interactions at Mission Bay Marsh during 1984, when Tijuana Estuary was nontidal and too dry for soil algae to grow. Her focus was on the cordgrassdominated lower marsh; she manipulated light levels in field experiments $110 \%, 25 \%$, $50 \%$, and $100 \%$ of incident light). After 2 or more weeks of exposure to the light conditions, replicate cores of algae were taken to the laboratory, and treatment effects were assessed with measures of chlorophyll concentration and photosynthetic lightresponse curves. Her experiments were repeated in winter and spring, when Enteromorpha dominated the algal mats, and in summer, when blue-green algae were abundant. The composition of the algal mat communities was similar to those at Tijuana Estuary during periods of good tidal flushing.

Kentula's results suggest that the hypothesis of Zedler $(1980,1982 \mathrm{~b})$ is too simple. Winter algal communities failed to increase productivity in proportion to increased light availability. Algal mats quickly became light-saturated (at 500-600 

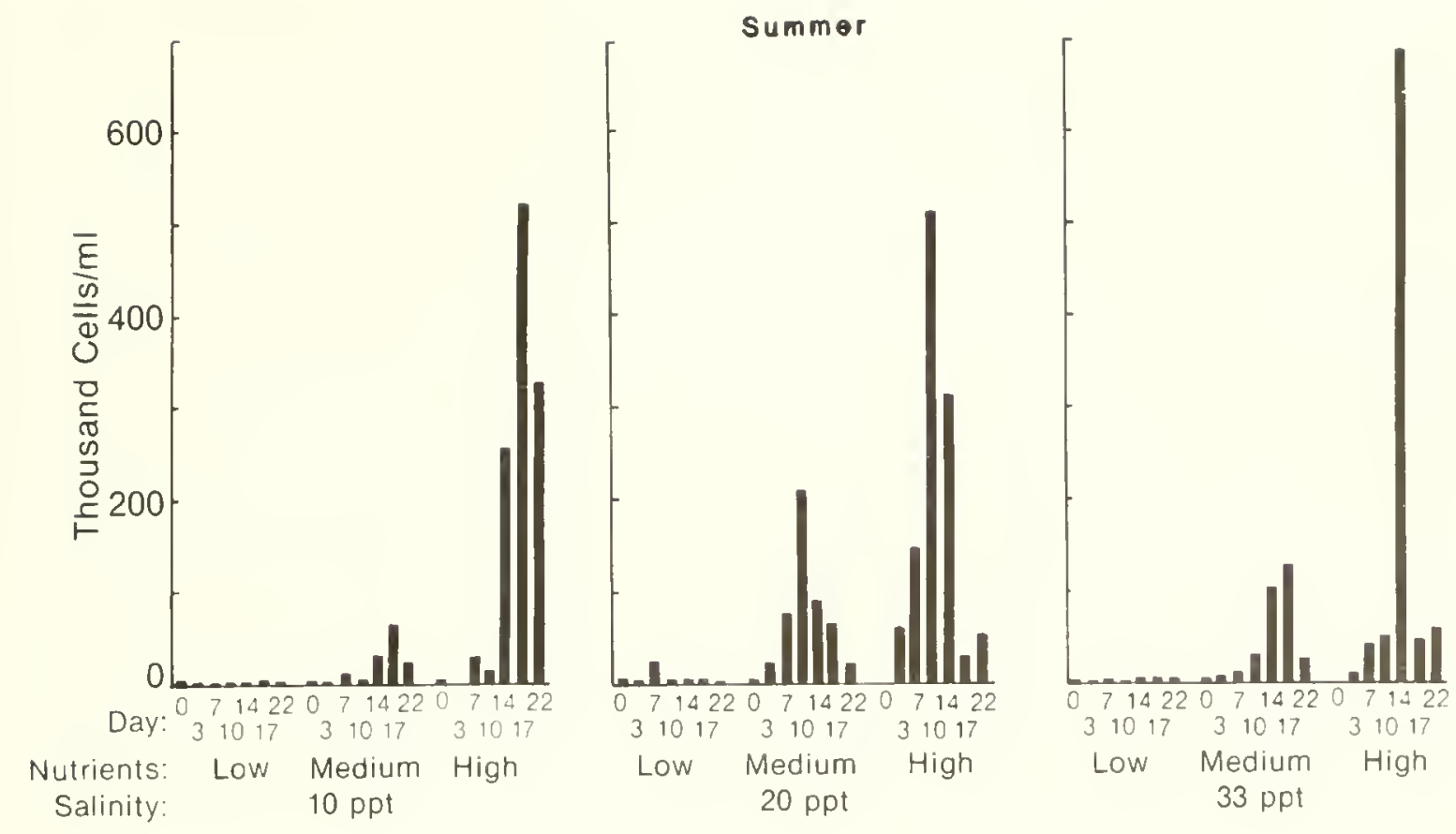

Winter
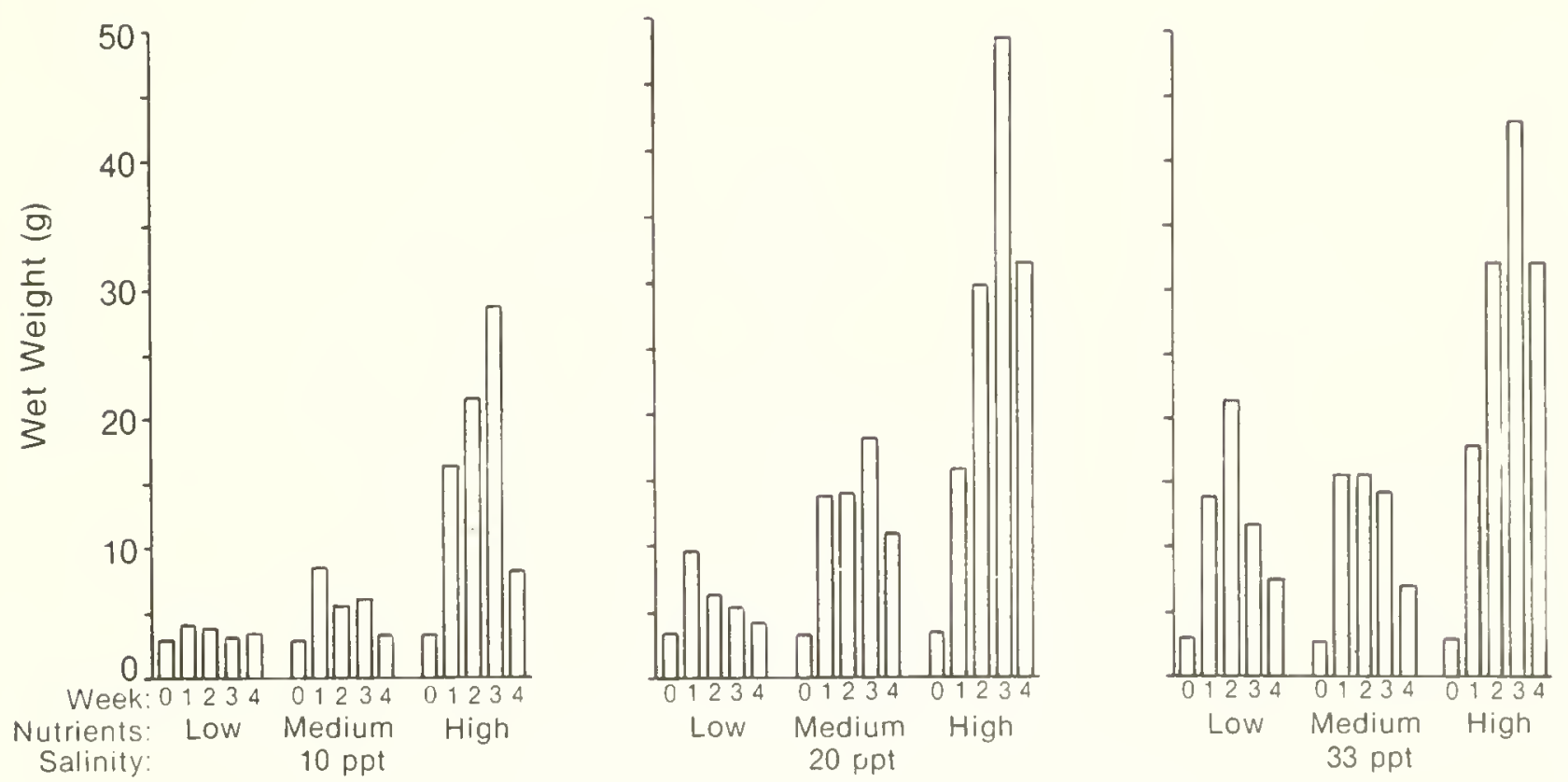

Figure 4.2. Results of manipulative experiments that varied water salinity and nutrient concentrations (using Milorganite additions) in microcosms at Tijuana Estuary. The phytoplankton response in the summer experiment is shown as increased cell density; the macroalgal response in the winter experiment is shown as increased biomass. Reprinted with permission from Rudnicki (1986) and Fong (1986). 
Table 4.2. Conceptual model of algal dynamics (modified from Rudnicki 1986 and Fong 1986).

Environmental condition Phytoplankton response Macroalgal response

Marine tides dominate

Initial low biomass

Initial low biomass

Nutrient addition

Increase

Increase

Warm temperatures

Dinoflagellates bloom

Decrease

Salinity reduction

Bluegreen monads bloom

General decrease unless

at $10 \mathrm{ppt}$

high nutrient conc.

Sluggish currents

Dilution and export

Biomass accumulates; bloom develops

No currents

Blooms develop

Water temperature rises, limits macroalgal bloom

Optimal conditions

High nutrients

High nutrients

No tidal flushing

Reduced currents

Warm temperatures

Any salinity

Cool temperatures

Saline water

Table 4.3. Productivity of benthic algal mats and vascular plants (from Zedler 1980).

Algal productivity estimates by habitat:

cordgrass Jaumea

saltwort shore grass

Gross primary productivity (1977)

(mean hourly, $\mathrm{mg} \mathrm{O}_{2} / \mathrm{m}^{2} / \mathrm{hr}$ )

Coefficient of variability (\%)

(mean daily, $\mathrm{g} \mathrm{O}_{2} / \mathrm{m}^{2} /$ day)

(annual, $\mathrm{g} \mathrm{O}_{2} / \mathrm{m}^{2} / \mathrm{yr}$ )

348

425

236

319

42

33

54

51

2.8

3.5

1.9

2.6

1038

1285

695

951

Gross primary productivity (1978)

(mg $\mathrm{O}_{2} / \mathrm{m}^{2} / \mathrm{hr}$ )

Coefficient of variability $(\%)$

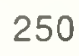

42

279

122

164

38

34

90

Net primary productivity

$$
\text { Vascular plants }\left(\mathrm{g} \mathrm{C} / \mathrm{m}^{2} / \mathrm{yr}\right.
$$

Algaea (g C/m²/yr)

340

$243^{b}$

164

Ratio of algae:vascular plants

276

34

185

253

0.8

1.4

0.8

1.0

aNet pri. prod. estimate $=0.85$ Gross pri. prod.; $P Q=1.2 . \quad$ bMiddle marsh datum. 
$\mu \mathrm{E} / \mathrm{m}^{2} / \mathrm{s}$ for temperatures ranging from 15 ${ }^{\circ} \mathrm{C}$ to $\left.33^{\circ} \mathrm{C}\right)$. Chlorophyll concentrations were significantly higher for algae grown in full sunlight, but rates of photosynthesis per unit chlorophyll were not much greater for this winter community.

Only the summer community responded as expected. The rates of photosynthesis for mats of blue-green algae and diatoms increased substantially with increased light (saturation at $900 \mu$ Einsteins $/ \mathrm{m}^{2} / \mathrm{s}$ for temperatures of $20{ }^{\circ} \mathrm{C}$ to $33^{\circ} \mathrm{C}$ ). Under conditions of high light, summer algal mats are thus limited by the shade of salt marsh vegetation. With light saturation and ambient temperatures, the summer algal mats are twice as productive as the winter community. The revised hypothesis is that canopy shade is a major limiting factor only for the summer community of epibenthic algae, which dominates the annual productivity. The relatively open vegetation canopies thus allow algae to contribute substantially to salt marsh productivity.

The Enteromorpha-dominated algal mats declined in summer, and increasing light availability appeared to limit the duration of the winter community indirectly. Kentula noted that green algae began to decline in late spring, but they did so more rapidly in open areas than under the cordgrass canopy. Higher temperatures and desiccation were likely causes. This suggestion is consistent with Rudnicki's (1986) finding that Enteromorpha declines in warm water and helps explain the predominance of epibenthic green algae only in winter at the Tijuana Estuary salt marsh (Zedler 1982a). In marshes at both Mission Bay and Tijuana Estuary, mats with blue-green algae and diatoms were dominant in summer.

Subsequent laboratory experiments using shallow-water microcosms were conducted by Fong (1991). Her findings further support the above conclusions. High light $(500$ $\left.\mu \mathrm{E} / \mathrm{m}^{2} / \mathrm{s}\right)$ and high temperatures $\left(25^{\circ} \mathrm{C}\right)$ favored blue-green algae and phytoplankton, while lower light $\left(150 \mu \mathrm{E} / \mathrm{m}^{2} / \mathrm{s}\right)$ and lower temperature $\left(12-20^{\circ} \mathrm{C}\right)$ stimulated the green macroalgae.

\subsection{VASCULAR PLANT PRODUCTIVITY AND BIOMASS}

The productivity of many salt marshes is high among natural plant communities, rivaling energy-subsidized agriculture in tons of carbon fixed per unit area per year. This generalization originated from studies in Georgia, where smooth cordgrass (Spartina alterniflora) dominates the intertidal zone. There, the widespread occurrence of cordgrass, the high rainfall and long growing season, the abundance of nutrients, and good tidal flushing are all reasons for productivity rates in excess of $3.5 \mathrm{~kg} / \mathrm{m}^{2} / \mathrm{yr}$ (Odum 1971; Pomeroy and Wiegert 1981; Chalmers 1982).

In Tijuana Estuary and most California estuaries, cordgrass has restricted areas of dominance. In addition, the summer droughts lead to hypersaline soils. Seneca and Blum (1984) demonstrated that the Pacific cordgrass (S. foliosa) has lower photosynthetic potential than its eastern counterpart when grown and measured in the laboratory. Substantial doubt that high productivity would be found in southern California salt marshes led Winfield (1980) and Onuf (1987, Onuf et al. 1978) to assess plant productivity in detail.

Winfield's work at Tijuana Estuary supported the hypothesis that the marshes of the region are less productive of vascular plant material than those in Georgia and elsewhere along the Atlantic and Gulf of Mexico Coasts. His use of the harvest method and Smalley's (1959) calculation, which sums biomass peaks of individual species, suggested that annual rates were well below 1 $\mathrm{kg} / \mathrm{m}^{2} / \mathrm{yr}$ net above-ground dry weight (Table 4.4). Winfield measured very low carbon content, however, indicating that ash (i.e., salts and metals) coniributed much to the oven-dry weights. The carbon content of 11 plant species ranged from $19 \%-35 \%$ of dry weight (Winfield 1980), compared to 
Table 4.4. Net aboveground productivity and net carbon (C) productivity (estimated from plant carbon data of $5 / 31 / 78$ ) of salt marsh vascular plants (data are per $\mathrm{m}^{2} / \mathrm{yr}$ from Winfield 1980).

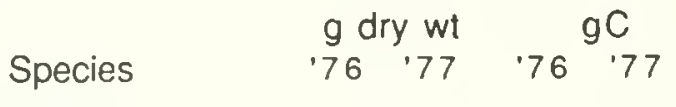

\section{Batis maritima}

saltwort

Frankenia grandifolia alkali heath

Jaumea carnosa

Limonium californicum sea lavender

Monanthochloe littoralis shore grass

Salicornia bigelovii annual pickleweed

S. subterminalis perennial glasswort

S. virginica pickleweed

Spartina foliosa cordgrass

Suaeda esteroa sea-blite

Triglochin concinnum arrow grass

Total

$\begin{array}{llll}689 & 904 & 191 & 239\end{array}$

$\begin{array}{rrrr}40 & 80 & 8 & 6 \\ 13 & 3 & 4 & 1 \\ 85 & 126 & 23 & 34 \\ 0 & <1 & 0 & 0 \\ 21 & 102 & 8 & 36 \\ 52 & 145 & 10 & 28 \\ 9 & 14 & 3 & 4 \\ 110 & 128 & 25 & 30 \\ 307 & 224 & 98 & 72 \\ 17 & 53 & 4 & 11 \\ 0 & 15 & 0 & 4\end{array}$

Two considerations discouraged us from repeating the vascular plant productivity studies. First, Onuf's experience convinced us that the work was enormously labor intensive, that funding agencies were unlikely to support further efforts, and that journals were unwilling to publish the detailed demographic analyses required to track branch production, loss, and replacement. Secondly, large changes in biomass followed the 1980 flood and indicated that short-term intensive studies were inappropriate for temporally variable marshes. Alternative approaches were called for, namely, longerterm monitoring of end-of-season biomass (Figure 4.3).

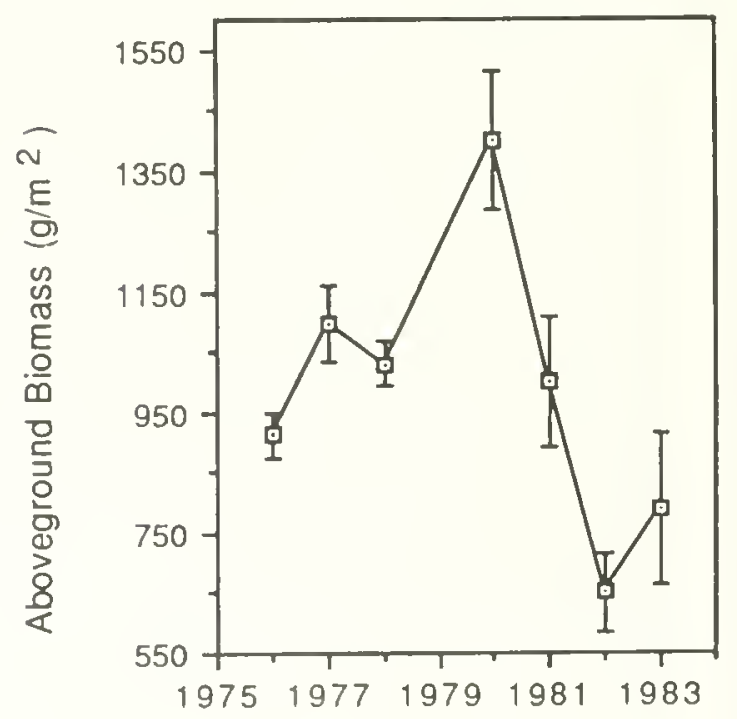

Figure 4.3. End-of-season live biomass of cordgrass plots at Tijuana Estuary (unpubl. data of PERL). Bars are \pm standard error; $n$ varied but was always more than 3 . 
Comparisons of productivity numbers with eastern marshes did not seem very profitable once we discovered how variable the marsh was in both biomass and composition. Tijuana Estuary, and probably all southern California marshes (cf. data for Los Peńasquitos Lagoon in Zedler et al. 1980), were found to differ greatly from year to year. Understanding how and why individual marshes differ in time became a more promising research goal (Chapter 5).

Winfield (1980) showed that cordgrass productivity was relatively high among the salt marsh species, but it contributed less than half that of the entire marsh (Table 4.4). His sampling scheme began with 46 randomly sampled stations within a 0.8 ha area of the marsh. More stations were added for the August sample ( $n=56$ ), then cut to 25 stations in 1977. At each station, plants were clipped to ground level within $0.25-\mathrm{m}^{2}$ circular quadrats.

Frequent sampling (Table 4.5) showed that there were differences in the timing of peak standing crop for each species. Pickleweed reached its maximum in August, while cordgrass peaked in July and again in September following fruit production. The standing crop for all species combined was at its minimum in March and maximum in August of 1976 and 1977 (Figure 4.4). Whole-marsh sampling was repeated in August of 1978, but efforts in later years were restricted to the lower marsh (Figure 4.3).

In both 1976 and 1977, standing crops doubled between March and August, but even in March, substantial live biomass was present (Figure 4.4). The criterion for "live" biomass was any stem with green material attached to it. Much of the live winter biomass consisted of fibrous shore grass, second-year cordgrass, and woody pickleweed stems. Despite large mortality between August and March, the standing dead biomass remained relatively constant. Thus, dead stems and leaves were rapidly incorporated into litter, exported, or decomposed.

Table 4.5. Standing crop ( $\mathrm{g}$ dry $\mathrm{wt} / \mathrm{m}^{2}$ ) of major salt marsh vascular plants for March (minimum biomass) 1976, 1977 and August (biomass peak) in 1976, 1977, and 1978 (from Winfield 1980).

\begin{tabular}{|c|c|c|}
\hline Species & $3 / 76$ & \\
\hline
\end{tabular}

\begin{tabular}{lrrrrr}
\hline Batis maritima, saltwort & 15 & 55 & 55 & 121 & 82 \\
Jaumea carnosa & a & 218 & 66 & 181 & 195 \\
Monanthochloe littoralis, shore grass & a & 170 & 159 & 218 & 143 \\
Salicornia bigelovii, annual pickleweed & $<1$ & 35 & 9 & 125 & 85 \\
S. virginica, pickleweed & 31 & 124 & 55 & 179 & 173 \\
Spartina foliosa, cordgrass & 55 & 211 & 130 & 280 & 256 \\
\hline & & & & & \\
Total standing crop & 426 & 858 & 514 & 1153 & 954 \\
\hline
\end{tabular}

a Jaumea and shore grass were not separated in the March 1976 sample. 


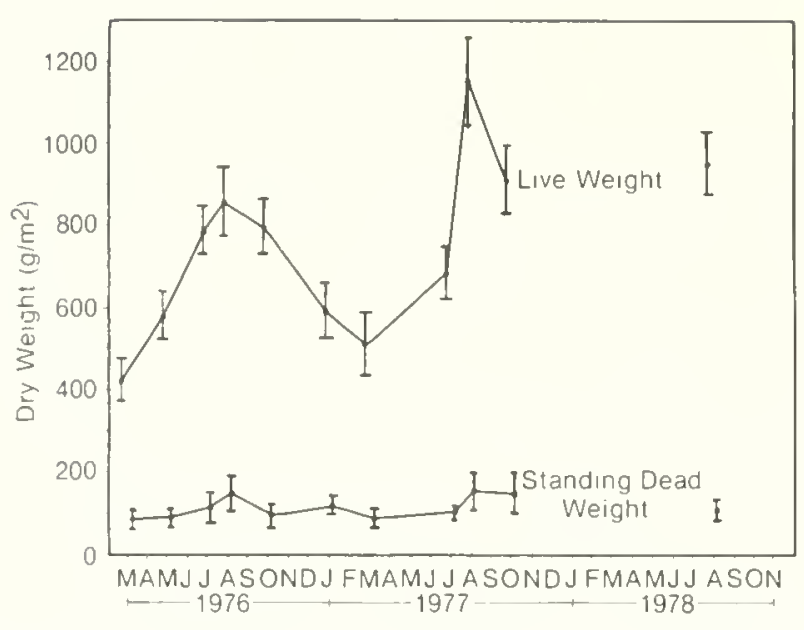

Figure 4.4. Live biomass and dead standing crop for salt marsh vascular plants. Vertical bars are \pm 1 standard error, $n=25$. Reprinted from Winfield (1980) with permission.

Species-specific differences in standing crop are easiest to see in the 1977 harvest data, for which the number of sampling stations was constant. The annual pickleweed (Salicornia bigelovii) had the largest temporal increase (13.4-fold), while shore grass had the least (1.4-fold). Year-to-year differences in August biomass were also large. Variability, then, is the rule; it is high from species to species, season to season, and year to year. Onuf (1987) reached the same conclusion in his analysis of pickleweed biomass at Mugu Lagoon.

\subsection{NUTRIENT INTERACTIONS}

Our understanding of the nutrient cycles at Tijuana Estuary is limited. Most of the work has focused on nitrogen, because nitrogen has long been accepted as the major limiting factor in coastal ecosystems. Smith (1984) has challenged that dogma and claimed that phosphorus is likely to limit estuarine systems, even though small-scale experiments might indicate that nitrogen controls plankion growth. Howarth and Cole
(1985) support the theory of nitrogen limitation and provide a convincing argument that anaerobic conditions favor nitrogen limitation.

Winfield (1980) studied nitrogen dynamics in detail and determined that there is a net flux of inorganic nitrogen from the tide waters to the marsh. His estimate of the amount of nitrogen imported by the marsh (2.2 $\mathrm{g} \mathrm{N} / \mathrm{m}^{2} / \mathrm{yr}$ ) was far less than the tolal required for above-ground plant growth (only $28 \%$ ), and even a smaller portion of the nitrogen required for vascular-plant and algal productivity combined $(6 \%)$. While these calculations do not rule out phosphorus or other nutrients as limiting, they do show a nitrogen deficit.

Data from the San Diego Regional Water Quality Control Board (G. Peters, WQCB, pers. comm.) show high ratios of phosphorus to nitrogen, so that phosphorus is less likely to limit whole-system productivity than nitrogen. Field sampling of soil nitrogen (Covin 1984) and channel nitrogen concentrations (Winfield 1980; Rudnicki 1986; Fong 1986) indicate that inorganic nitrogen is often present in very low quantities.

Nitrogen fixation rates have not been measured at Tijuana Estuary. A one-year study of nitrogen fixation at Sweetwater Marsh National Wildlife Refuge on San Diego Bay (Zalejko 1989) showed that microbes were fixing nitrogen both at the marsh surface and in the rhizosphere. However, absolute rates (as estimated by acetylene reduction) appear to be very low.

In experimental work at Tijuana Estuary, nitrogen additions stimulated vascular plant growth (Covin 1984; Covin and Zedler 1988). Not only was nitrogen found to limit plant growth, it was shown to affect the competitive interaction between cordgrass and pickleweed (Section 4.4.2).

In 1983, frequent sewage spills from Mexico lurned our attention to the more practical problems of how wastewater affects estuarine organisms. Nutrient-algae 
interactions were investigated in manipulative experiments using Milorganite (commercially available dried sewage sludge) added to microcosms containing channel macroalgae and phytoplankton (Rudnicki 1986 and Fong 1986; Section 4.1).

\subsubsection{Nitrogen Fluxes in 1977-1978}

Winfield (1980) set out to determine 1) the net direction of inorganic nitrogen movement of selected tidal cycles, 2) the relative importance of ammonium, nitrate and nitrite in channel waters, and 3 ) the seasonal patterns in inorganic nitrogen flux. His field data included both flood and nonflood years, so that comparisons became possible and our ability to extrapolate to longer periods of time was improved.

Concentrations of inorganic nitrogen were sampled monthly in two tidal creeks during the flood and ebb cycles of spring tides. Water samples were analyzed for ammonium, nitrate, and nitrite, using methods outlined in Strickland and Parsons (1972). One of the tidal creeks drained an area dominated by mixed cordgrass and pickleweed, and the other drained an area dominated by succulents. The two stations did not differ in nitrogen dynamics, despite their difference in vascular plant dominance. Therefore, they were averaged to calculate nitrogen fluxes.

Ammonium was usually the dominant form of nitrogen. Only after the January-February 1978 flooding of Tijuana River did nitrate concentrations exceed those of ammonium. Ammonium (as atomic $N$ ) ranged from 0 to $16.8 \mu \mathrm{g} \mathrm{N} / \mathrm{l}$ (monthly means), with higher concentrations in winter and spring, and higher concentrations in flood, rather than ebb tides (Figure 4.5). A net import was calculated for the study period. Concentrations of nitrate, averaged monthly, ranged from 0.2-3.6 $\mu \mathrm{g} \mathrm{N} / \mathrm{l}$, except for the March 1978 postflood sample $(25 \mu \mathrm{g} \mathrm{N} / \mathrm{l})$. Nitrite was lower, at 0.7-1.4 $\mu \mathrm{g} \mathrm{N} /$, and was usually highly correlated with nitrate concentrations. Calculations for the study period indicated that both nitrate and nitrite were exported in small amounts. Overall,
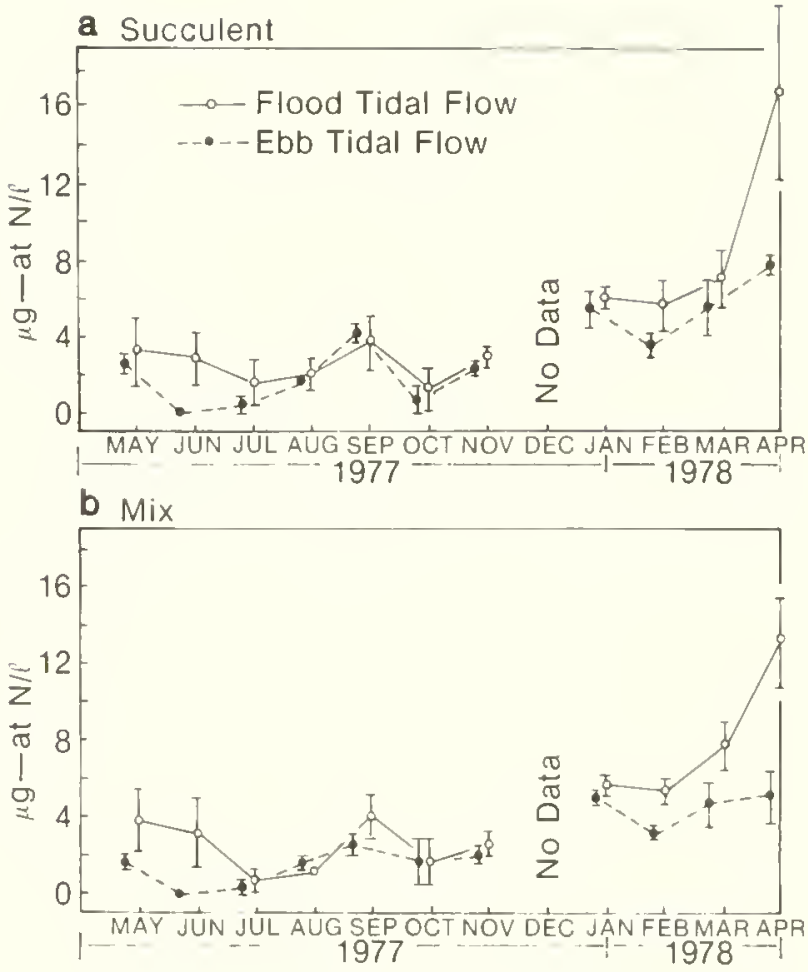

Figure 4.5. Concentrations of ammonium nitrogen in flood and ebb tidal waters for a) the succulent-dominated study site and b) the mixed cordgrass-succulent study site of Winfield (1980). Vertical bar is \pm 1 standard deviation. Reprinted from Winfield (1980) with permission.

however, there was a net import of inorganic nitrogen (2.2 g N/m²/yr; Figure 4.6).

Streamflows did not appear to be important to the nitrogen cycle except during flood years. The shift from dominance of dissolved inorganic nitrogen by ammonium to dominance by nitrate is a good indictor of riverine influence. Sewage inputs, on the other hand, are dominated by ammonium (Covin 1984). The preponderance of ammonium in 1977-78 channel waters and also in 1985 data of Rudnicki (1986) and Fong (1986) indicate long-term nitrogen subsidies from urban and agricultural wastewater. 
a Succulent
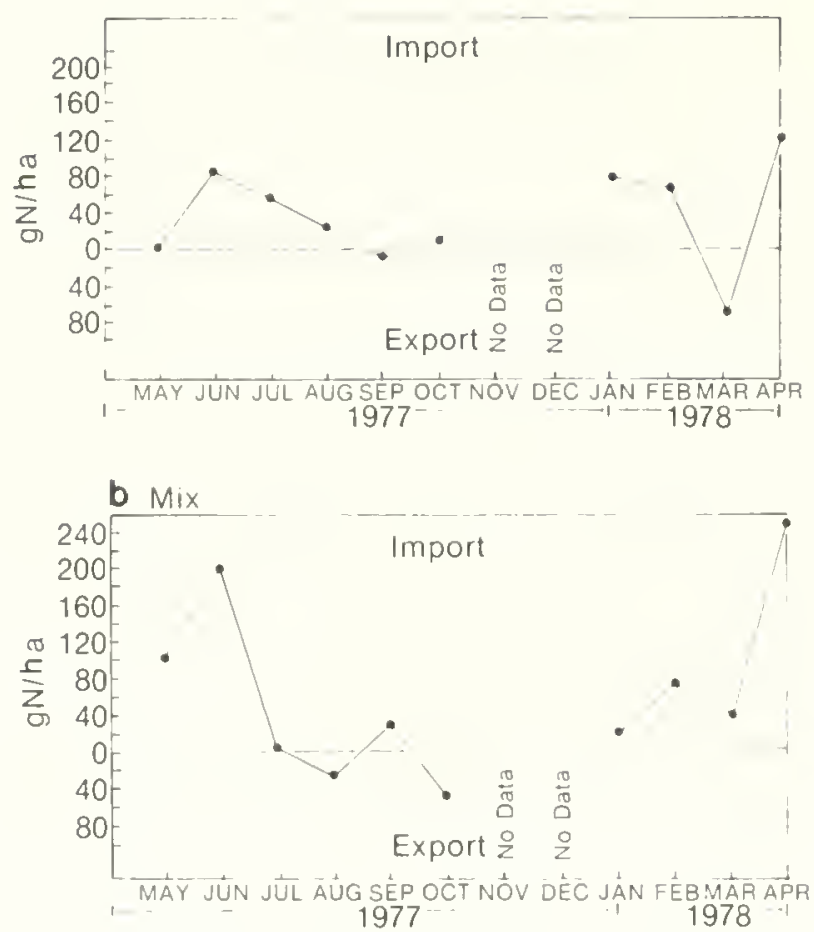

Figure 4.6. Net flux of total inorganic nitrogen dissolved in the tidal waters for a) the succulent-dominated study site and b) the mixed cordgrass-succulent study site of Winfield (1980). Reprinted with permission from T. Winfield.

Fluxes of organic nitrogen have not been measured but can be assumed from Winfield's data, which show a net export of dissolved organic carbon (Section 4.5.3). It is likely that the inorganic nitrogen that is imported with the incoming tide is fixed into organic matter and released to channel waters as particulate and/or dissolved organic nitrogen. The marsh functions as a transformer of inorganic to organic matter.

Imported nutrients could enter the marine food chain as amino acids and detrital particles become available to consumers. During sewage spills, concentrations of organic nitrogen are much higher, and both water quality and estuarine organisms are severely damaged.

\subsubsection{Nitrogen Additions to Salt Marsh Vegetation}

We have long been aware of spatial and temporal variability in marsh plant growth, especially for cordgrass. While soil salinity reductions that accompany flooding (Chapter 5 and Zedler 1983b) have been shown to be important in controlling growth, flooding does not explain all of the growth dynamics. Furthermore, freshwater influence is not independent of nutrient influxes, as the previous section shows. When the Tijuana River flows, there are many changes in total water chemistry.

Before Covin's (1984) study at Tijuana Estuary, the influence of nitrogen on salt marsh vegetation was in question. D. Turner (SDSU; unpubl. data) had fertilized pickleweed-dominated vegetation at San Diego River Marsh and found large increases in vascular plant productivity. However, when Nordby added the same concentrations of urea to cordgrass transplants at Tijuana Estuary, he failed to see a growth response (Nordby et al. 1980). The latter experiment took place during 1980, when major floodwater may have enriched the marsh soils with nitrogen or stimulated local nitrogen recycling. These conflicting results stimulated Covin to develop a detailed investigation of nitrogen-plant interactions.

Covin's first step was a broad survey of soil nitrogen in 1981, using 67 of the 102 lower marsh monitcring stations at Tijuana Estuary (Chapter 5). Soil nitrogen proved to be variable within stations, among stations, and among transects. There was only a hint that cordgrass growth was related to soil nitrogen concentrations; the transect with highest soil nitrogen had the highest total stem length (a biomass estimate) of cordgrass.

Reasoning that nutrient uptake by cordgrass might be enhanced by nitrogen concentrations or reduced by competitive uptake on the part of pickleweed, Covin set up two-way experiments with both nitrogen (turea) and presence of competitors 
( \pm pickleweed) as variables. In addition, he repeated the \pm urea experiment in an area of pure cordgrass. The field experiments were carried out in 1983 near transects TJE-28 and TJE-30 (Chapter 5). Urea was broadcast onto the marsh soils biweekly through the growing season in + urea plots. Biomass was measured in August 1983 and significant treatment effects were found. Urea stimulated only the growth of pickleweed; competitor removal stimulated only the growth of cordgrass (Table 4.6). Pickleweed was the superior competitor for nitrogen uptake; its biomass increased significantly with urea additions, with no significant effect from the presence of cordgrass.

Nitrogen added to pure stands of cordgrass was readily taken up by the plants--so thoroughly that soil nitrogen concentration did not increase. Instead, the nitrogen went directly into the leaves, and could be measured only as increased nitrogen concentrations in plant tissues. Insects seemed able to locate plants with enhanced tissue nitrogen, and it appeared that local outbreaks did serious damage to cordgrass. Thus, the net effect of urea fertilization on pure stands of cordgrass may be beneficial, by stimulating growth, or detrimental by causing insect damage.

The experimental results (Table 4.6) were complex, and they led to a new model of nitrogen-marsh dynamics (Covin 1984; Covin and Zedler 1988): Nitrogen is certainly limiting to vascular plant growth. Additions will stimulate cordgrass in pure stands, but herbivores may gain the ultimate benefit from the increased nutritional quality of the plants. In mixed stands, additions stimulate pickleweed, which then outcompetes cordgrass.

Some interesting questions remain: Why didn't nutrient additions stimulate herbivory on pickleweed? Was it chance that precluded an outbreak in the fertilized plots? Perhaps, but a 1984 experiment performed by Beare and Beezley (unpubl. data) suggests otherwise. Plots with urea added had less herbivory than plots fertilized with Milorganite. In replicate plots of pure pickleweed, urea was added biweekly along
Table 4.6. Standing crop of cordgrass and pickleweed in August 1983 in replicate $(n=$ 2) plots with and without urea additions and with and without competitors removed. All data are aboveground biomass in $\mathrm{g} / \mathrm{m}^{2}$ (from Covin 1984).

\begin{tabular}{ccc}
\hline Cordgrass & $\begin{array}{c}\text { With } \\
\text { Dickleweed }\end{array}$ & $\begin{array}{c}\text { Without } \\
\text { pickleweed }\end{array}$ \\
Without urea & 577 & 1,282 \\
Pickleweed & $\begin{array}{c}\text { With } \\
\text { cordgrass } \\
\text { With urea }\end{array}$ & $\begin{array}{c}\text { Without } \\
\text { cordgrass }\end{array}$ \\
Without urea & 1,525 & 1,484 \\
& 1,038 & 1,316 \\
\hline
\end{tabular}

with fresh water to cylinders of $0.33 \mathrm{~m}^{2}$ area that penetrated $10 \mathrm{~cm}$ of soil and protruded $30 \mathrm{~cm}$ aboveground. Milorganite was added in low, medium, and high concentrations to additional cylinders, with the high treatment adding an amount of nitrogen equal to that in the urea treatment. Other cylinders received fresh water only. Each treatment was replicated four times. Plant growth increased with nutrients added in high concentrations, but results were complicated by insect attack.

Beetle herbivory became pronounced in August, and the lengths of chew marks were summed for stems sampled from each treatment. Insect damage in plots fertilized with Milorganite averaged $40 \mathrm{~mm} /$ branch, while those with urea averaged $4 \mathrm{~mm} / \mathrm{branch}$. The growth response to the two fertilizers was similar, but the insect response was not. Likewise, Covin did not find insect damage on urea-fertilized pickleweed, although he did on cordgrass (see above). There may be a differential insect response to different plant species fertilized by the same nitrogen source.

However, these results actually suggest more questions than they answer. Because the 
work was initiated in a year of unusual hydrological conditions (no tidal flushing for most of the year, no rainfall in winter of 1984), because field breakdown rates of Milorganite are unknown, and because fertilizers were applied in water solution, it is not clear how broadly the findings can be generalized. Finally, if some plant species become more palatable upon urea fertilization than others, what mechanism is involved? Is it a difference in cordgrass vs. pickleweed herbivores, or a difference in the grass vs. succulent plant chemistry? Clearly, there are multiple routes of research to be pursued in understanding how nitrogen and other nutrients influence salt marsh functioning.

More recently, Johnson (1991) fertilized plots of cordgrass with urea in two San Diego Bay Marshes, Paradise Creek Marsh and the Chula Vista Wildlife Reserve (a man-made dredge spoil island). She followed foliar nitrogen levels and insect populations in an attempt to determine if herbivory increases with soil nitrogen amendments. The results were complicated, but they do help explain variations in field observations. In the manmade marsh, predatory arthropods were absent, and herbivorous insects responded to fertilization and increased foliar nitrogen levels. In the natural marsh, there were more predators, such as beetles and spiders. Adding nitrogen must have stimulated herbivore populations (e.g., Prokelisia dolus), but the higher densities could not be measured. Instead, the effect was apparent as an increase in predatory beetle (Coleomegilla fucilabris) populations. Johnson's work documents the variability and complexity of insect responses to nitrogen additions. Whether or not nutrients increase herbivore damage depends in part on how rapidly the predators locate and crop the herbivores.

\subsection{ENERGY FLOW}

For many years, salt marshes have been viewed as food producers that subsidize coastal bays and nearshore waters (Odum 1971). Haines (1979) and Nixon (1980) challenged that dogma for Atlantic Coast marshes, as did Winfield (1980) for Tijuana Esluary. As a result, investigators have concluded that coastal marshes display a high degree of individuality. Their ability to fix carbon at remarkable rates remains unchallenged, but the ecological fate of that carbon is highly variable. Systems with large river flows are likely to transport large fractions of their net primary production during spring runoff; systems with broad tidal amplitude may be highly susceptible to exporting organic matter year round; marshes experiencing rapid sealevel rise may accumulate plant matter in the sediments; small semi-enclosed wetlands may use the energy of pholosynthesis and recycle large portions of their fixed carbon. The high productivity, then, is either exported (usually as detritus), accumulated (as peat) or released in respiration (energy lost as heat; carbon recycled as carbon dioxide).

Studies at Tijuana Esluary add another complication--that of tremendous temporal variability in the processes that determine the fate of organic carbon. This section reviews research that has evalualed detrital production (Winfield 1980), feeding and growth rates of estuarine animals (Williams 1981; Boland 1981), carbon fluxes (Winfield 1980), and variations in the system's ability to "filter" materials from incoming waters (Zedler and Onuf 1984).

\subsubsection{Detrital Production}

As live plant material dies and is transformed into small particles, detritus is "produced." It is much more than a mechanical process, because fungal and bacterial decomposers are integrally involved in the transformation. As they help to break down the fixed carbon, they simultaneously enrich the particles with organic nitrogen gleaned from tidal waters. Two lines of evidence indicate that detritus production is far from constant at Tijuana Estuary. The first is Winfield's (1980) work on litter dynamics (dead organic matter beneath the marsh canopy); the second is his direcl measurements using litter bags.

The seasonal changes in litter (Figure 4.7) were highly variable. Litter accumu- 


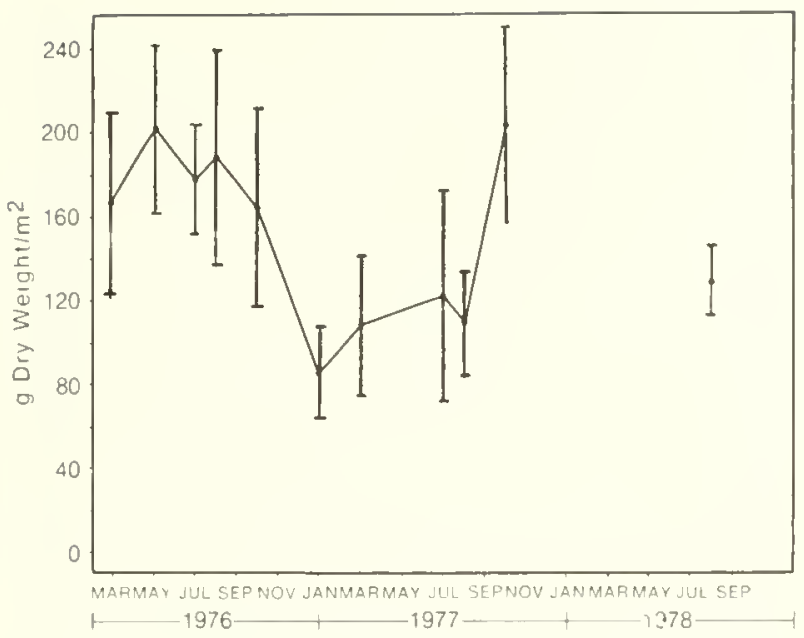

Figure 4.7. Seasonal dynamics of litter in the salt marsh of Tijuana Estuary. Vertical bars are \pm 1 standard error, $n=25$. Reprinted with permission from $\mathrm{T}$. Winfield

lated through May in 1976 but decreased through November in 1977. August values were high in 1976 (about $200 \mathrm{~g} / \mathrm{m}^{2}$ ) and low in $1977-78\left(100-130 \mathrm{~g} / \mathrm{m}^{2}\right)$. The processes responsible for litter removal are likewise variable, and tracing the fate of plant losses is a complex problem. Casual observations indicate that the coincidence of high tides and strong winds results in major transport of litter from the low marsh to the high tide line. Large wrack deposits are occasionally obvious, but there are many months when debris lines are hard to locate.

Data on decomposition rates (Table 4.7) show large differences between: species, leaves and stems, live and dead fractions, and locations of litter bags in the marsh. While litter bags were deployed in the marsh only during one year, other data indicate year-toyear differences in the availability of plant parts for various marsh species (Section 4.3). Furthermore, some of the succulent plants are highly susceptible to breakage (e.g., saltwort, Batis maritima), while the grasses are not. Leaves of saltwort are readily detached and floated away at the end of the growing season, as are their fleshy fruits. Coupling the differences in plant production

and mortality through time with differences in disappearance rates of species and plant parts shows high temporal variation in detritus production.

\subsubsection{Feeding and Growth Rates}

Plant material produced by the salt marsh is used both directly (herbivory) and after fractionation to detrilal particles (detritivory). We are virtually ignorant of the first process at Tijuana Estuary. But the abundance of insects found on various salt marsh plants insures that it is an important energy flow pathway (e.g., outbreaks of Diptera on cordgrass documented by Covin 1984; Coleopteran damage on pickleweed documented by Beare and Beezley, both discussed in Section 4.4).

Table 4.7. Decomposition rates of selected plant material (from Winfield 1980).

$$
\text { Locationa }^{\mathrm{a}} \% / \mathrm{mo} \text {. } \% / \mathrm{yr}
$$

Live material:

Cordgrass shoots

Cordgrass leaves

Whole shore grass

Whole Jaumea

Pickleweed shoots

Annual pickleweed

Dead material:

Cordgrass shoots

Cordgrass shoots

Cordgrass leaves

Cordgrass leaves

Annual pickleweed

Annual pickleweed

$\begin{array}{lrr}\text { ecotone } & 7.1 & 85 \\ \text { ecotone } & 9.1 & 100 \\ \text { upper } & & \\ \text { marsh } & 3.1 & 37 \\ \text { ecotone } & 9.1 & 100 \\ \text { ecotone } & 9.1 & 100 \\ \text { ecotone } & 9.1 & 100\end{array}$

$\begin{array}{lrr}\text { creek } & 11.1 & 100 \\ \text { ecolone } & 4.0 & 48 \\ \text { creek } & 33.3 & 100 \\ \text { ecolone } & 8.3 & 100 \\ \text { creek } & 20.0 & 100 \\ \text { mid- } & & \\ \text { marsh } & 4.2 & 50\end{array}$

aEcotone = upper extent of cordgrass zone. 
Other evidence that herbivores consume large fractions of live plants comes from welland restoration sludies, wherein new cordgrass transplants are often heavily grazed by ground squirrels and rabbits (Zedler 1984a), as well as by insects (Johnson 1991). Why transplanted marsh show more evidence of mammalian grazing than natural marshes is unclear. The fact remains that live cordgrass can be highly palatable to marsh consumers.

Additional evidence for in situ consumption of estuarine productivity comes from studies of invertebrate growth rates. Williams (1981) examined growth rates of mussels (Mytilus edulis) at Tijuana Estuary for comparison with laboratory-reared individuals fed diets of cordgrass and pickleweed detritus. In the laboratory, mussels lost weight when fed freshly made detritus but grew slightly when fed aged detritus. The highest growth rates were found with mussels grown in the dredged channel at Tijuana Estuary. Williams (1981) concluded that bacteria and phytoplankion are more important in the funnelling of estuarine productivity to benthic consumers than detritus from vascular plants. It remains to be demonstrated how much the bacteria or phytoplankion use dissolved organic carbon that has been fixed by, and later leached from, marsh vegetation.

\subsubsection{Carbon Fluxes}

At the same time that Winfield (1980) studied nitrogen fluxes in tidal creeks, he sampled organic carbon to determine the net flux of different components: dissolved organic carbon (DOC) and particulate organic carbon (POC). Because POC is the sum of three major components, live phytoplankton, other live plankion, and dead particles, Winfield identified these analytically. Live biomass was determined from measurements of ATP (total live) and the algal portion was calculated from chlorophyll a measurements, so that other plankton could be estimated by subtraction from totals. Dead biomass was calculated by subtracting the live fraction from total POC. The difficult but precise analyses were necessary to quantify tidal water composition. Over 1,850 samples were processed for carbon analysis in the 2-year study (Winfield 1980).

Most studies of carbon flux ignore the DOC component. Yet at Tijuana Estuary, this was the major form of carbon export (Figure $4.8)$. Concentrations of DOC in ebb tide water often exceeded concentrations in flood tide water (Figure 4.9). Furthermore, concentrations of $C$ in the dissolved form averaged much higher than in the particulate form (Figure 4.10). DOC ranged from 1 to $11 \mathrm{mg} \mathrm{C/l}$, while POC ranged from 0.4 to 1.8 $\mathrm{mg} \mathrm{C/l}$ of creek water. Thus, the ultimate removal of organic materials produced in the marsh results from processes such as leaching of DOC from both live and dead plants and animals and excretion of organic molecules by plants and animals.

Detrital carbon dominated the particulate component in tidal waters, sometimes making up $98 \%$ of the POC, and never less than $36 \%$ (Winfield 1980). Live organisms made up the majority of the particulate matter only in June 1977 and April 1978. Both times the live POC was largely algae, as indicated by chlorophyll concentrations. In contrast with DOC results, the POC data suggested that the salt marsh entrains particulate materials, although this is the net result of frequent import and occasional export.

What fraction of marsh productivity is exported to tidal creeks? Based on his 10 month study period, Winfield (1980) estimated an annual export of $40 \mathrm{~g} \mathrm{C} / \mathrm{m}^{2} / \mathrm{yr}$ as DOC for the area dominated by succulents and $110 \mathrm{~g} \mathrm{C} / \mathrm{m}^{2} / \mathrm{yr}$ for the area of mixed cordgrass and succulents. A net import of particulate carbon was determined for POC, with annual estimates at $5.6 \mathrm{~g} \mathrm{C} / \mathrm{m}^{2} / \mathrm{yr}$ for the areas included in his two sampling stations. At most, then, there was a net removal of $105 \mathrm{~g} \mathrm{C} / \mathrm{m}^{2} / \mathrm{yr}$, which is well below the nel amount produced by vascular plants (approximately $220 \mathrm{~g} \mathrm{C} / \mathrm{m}^{2} / \mathrm{yr}$; Section 4.3) and epibenthic algae (185-340 $\mathrm{g} \mathrm{C} / \mathrm{m}^{2} / \mathrm{yr}$ ). Additional fluxes of debris probably occurred on the water surface and as wind-borne materials; neither was measured 
a Succulent
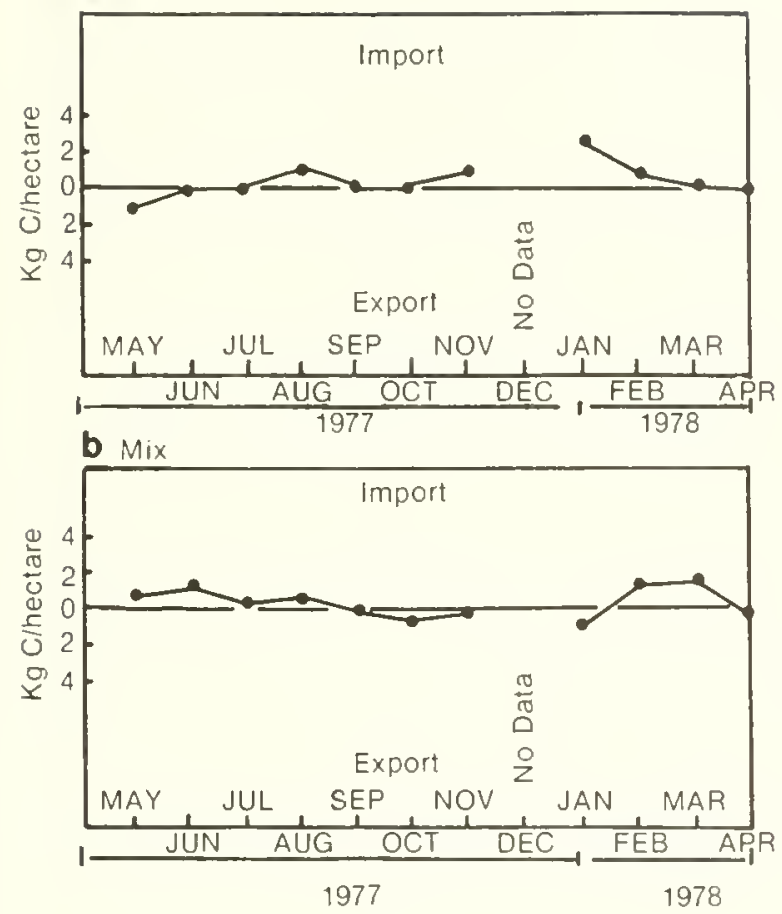

a Succulent
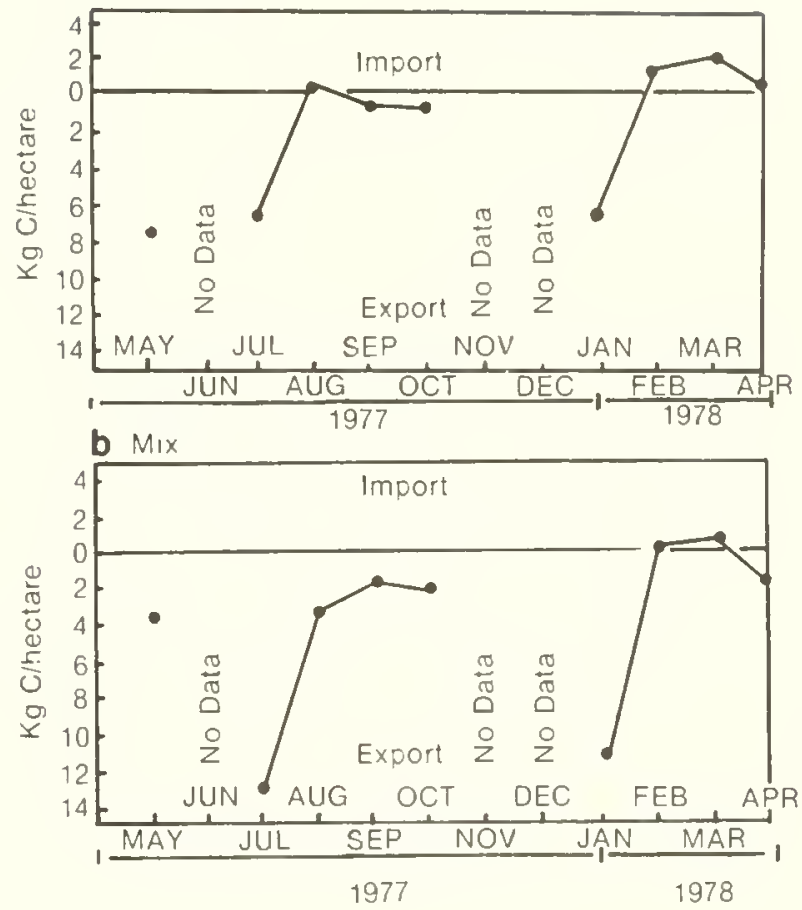

Figure 4.8. Net flux of particulate (left) and dissolved (right) organic carbon in tidal waters of a) the succulent-dominated and b) mixed cordgrass-succulent study sites of Winfield (1980). Reprinted from Winfield (1980) with permission.

because of enormous difficulties in sampling. Since temporal variability in all of these processes is high, it is unwise to set a percentage for materials lost from the marsh to adjacent tidal creeks. Suffice it to say that, from these data, most of the marsh plant production appears to be used within the marsh.

\subsubsection{Temporal Variability in Filtering Functions}

There is little information on year-10year differences in nutrient uptake rates, sediment accretion, and peat formation. Limited studies of peat accumulation (Scolt 1976; Mudie and Byrne 1980) show that marsh elevations have increased through geologic time, and comparisons of elevations before and after flooding (Zedler 1983b) document short-term accretion. Not much can be said about the processes that reverse these "filtering" functions either. No measurements have been made of erosion, other than what is obvious from aerial photos (Chapter 2). Overall, Tijuana Estuary is accumulating sediments within the channels and losing area due to shoreline retreat. The importance of catastrophic sedimentation events makes prediction difficult.

A conceptual model was developed by Zedler and Onuf (1984) to describe estuarine filtering during the wet and dry seasons of nonflood years and during flood years (Figure 4.11). Nonflood years are the most commonly occurring condition. During these times, the estuary is believed to be a sink for nutrients and sediments coming from both the watershed and the ocean. It is also a sink for salts that are brought in by tides and accumulated through evaporation. 
We have no data on nutrient inputs during natural flood events at Tijuana Estuary, and can only speculate that nutrient influxes and accumulation rates are greater during flood than nonflood years. All studies of filtering functions during flooding came after hydrological modifications had changed both the availability of sediments for transport and the rates and timing of streamflows. Onuf's comparisons of flood effects at Mugu Lagoon before and after 1970 indicate that sedimentation was much less during floods that preceded watershed development. The combined floods of 1978 and 1980 filled in the central bay of Mugu Lagoon and decreased low-tide volume by $40 \%$ (Onuf 1987).

Disturbances within the watershed of Tijuana Estuary have destabilized slopes and made available large volumes of sediment, just as in the watershed of Mugu Lagoon. Unlike Mugu Lagoon, Tijuana Estuary is somewhat protected from sediment deposition by dams that regulate $78 \%$ of the watershed. Still, agricultural and urban developments below Rodriguez Dam disturb soils that can be mobilized by flooding. Aerial photos of the 1980 flood show major sediment plumes flowing out of the mouth of Tijuana Estuary. Only a small portion of the sediment was deposited within the wetland.

Because the bulk of the filtering process occurs as sedimentation during catastrophic events, it is not clear how important the vascular plants are in controlling the processes of accretion and erosion. In coastal systems worldwide, there are attempts to stabilize shorelines by maintaining good cover of beach grasses and cordgrass. Al Tijuana Estuary, the importance of beach vegetation in reducing sediment mobilization is clear, but the role of cordgrass is not. Cordgrass does not occur in the path of the river; thus, it cannot reduce erosion along the river banks. Some areas of pickleweed in the estuary and even some of the woody plants upstream were scoured out by the 1980 flood. Cordgrass may be effective in increasing sedimentation within the salt marsh. Whether this is beneficial or detrimental to maintenance of wetland habitats depends on the combined rates of accretion and sea level rise.

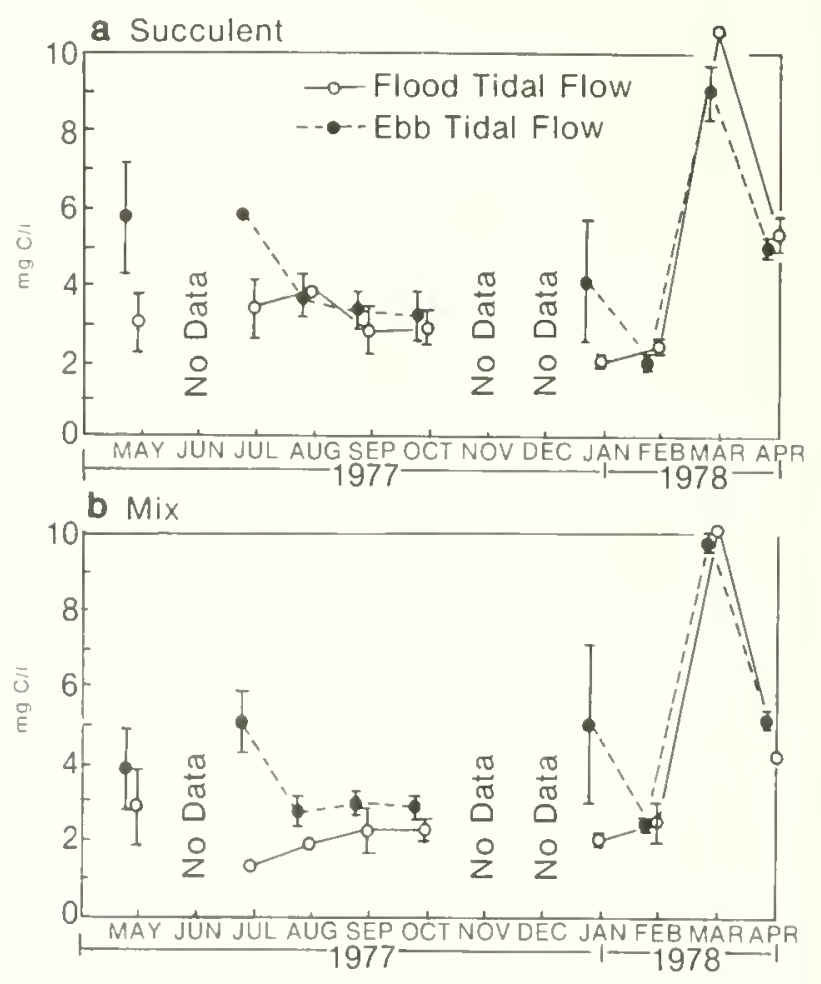

Figure 4.9. Mean concentrations of dissolved organic carbon for flood and ebb tidal waters of a) the succulent-dominated and b) the cordgrass-succulent study sites. Reprinted from Winfield (1980) with permission. 


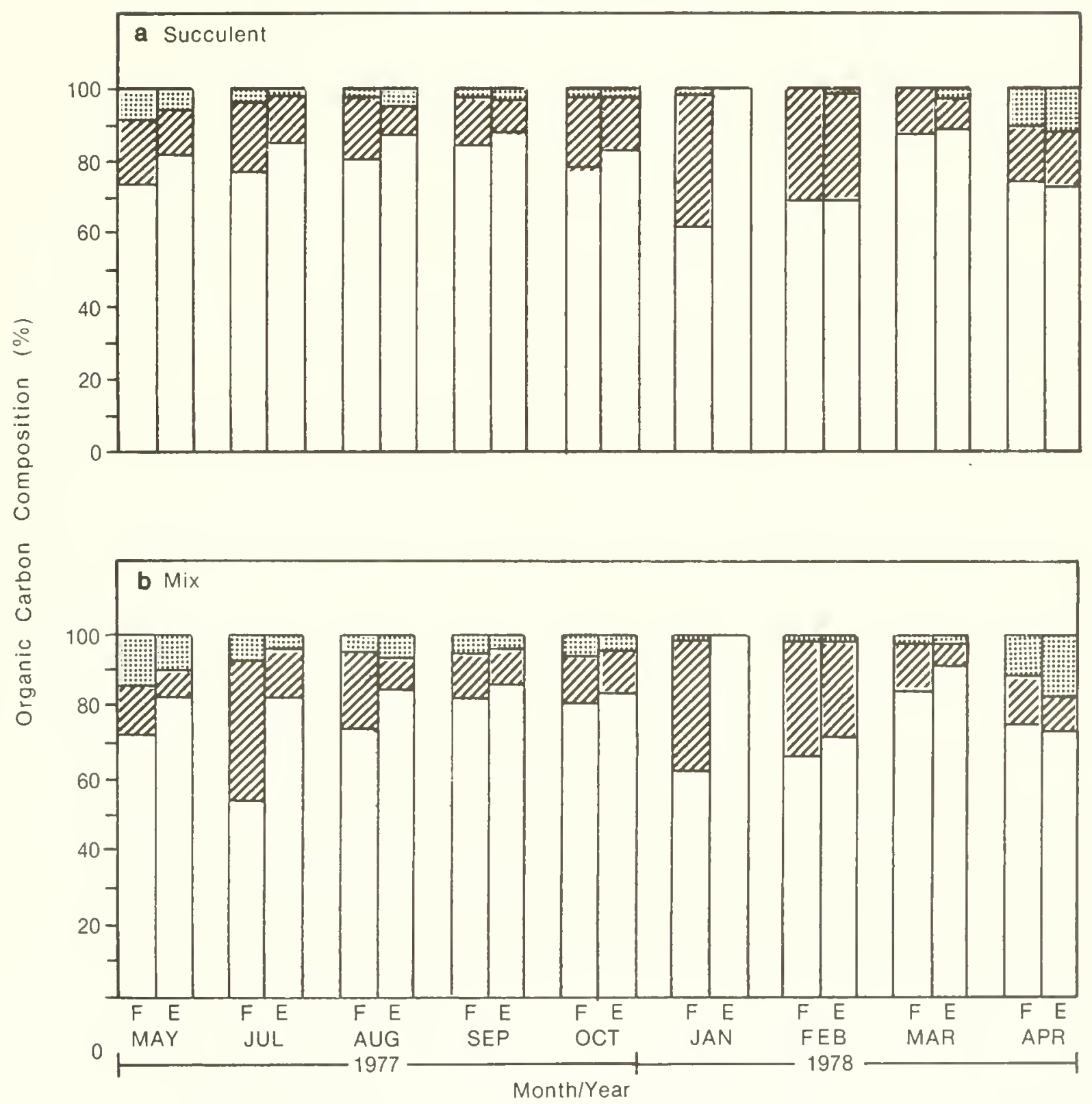

Figure 4.10. Percent composition of total organic carbon in flood and ebb tidal waters in a) the succulent-dominated and b) the cordgrass-succulent study sites of Winfield (1980). F = flood tidal flow; $E=$ ebb tidal flow. Reprinted from Winfield (1980) with permission. 

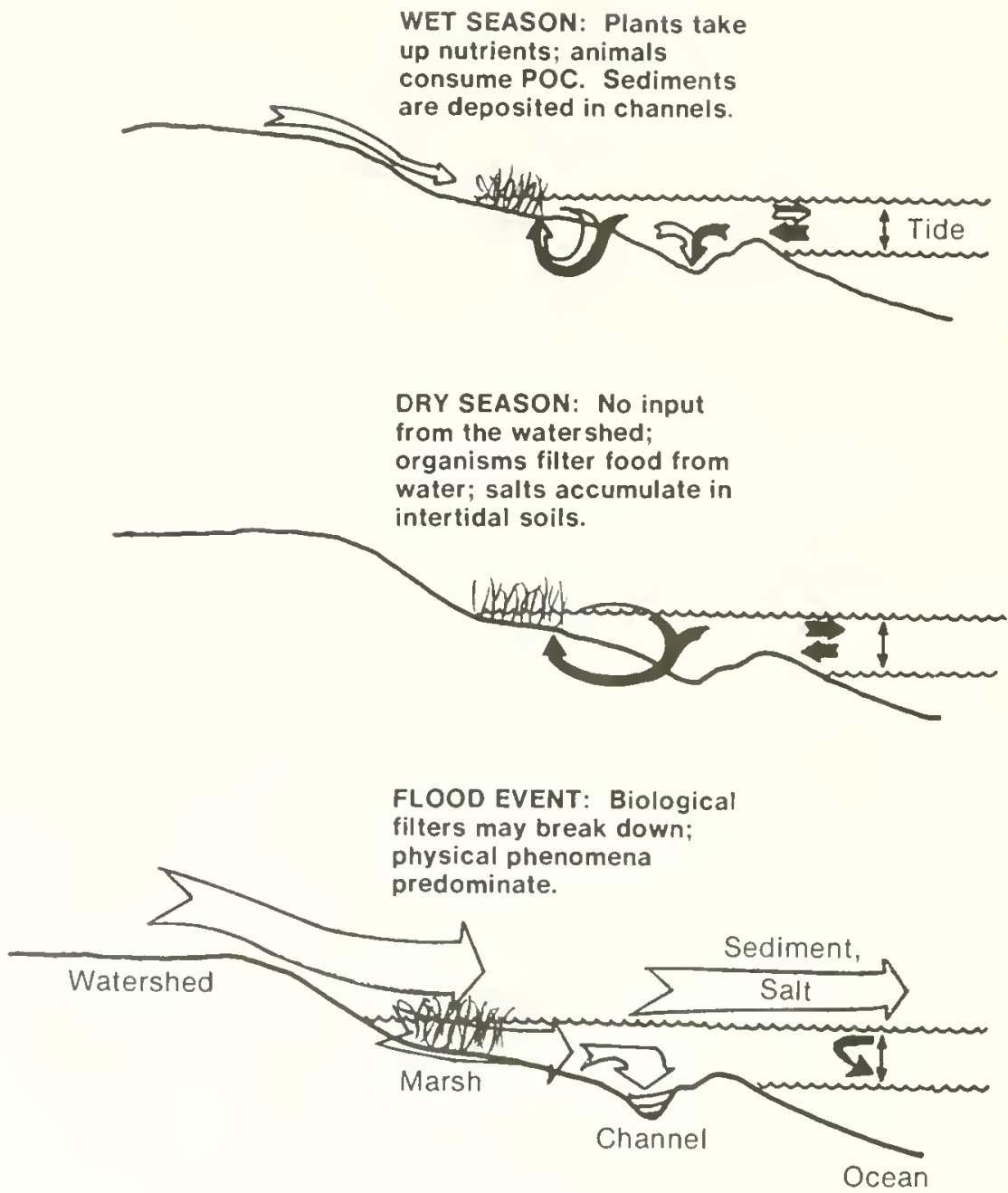

Figure 4.11. Conceptual model of filtering functions during nonflood years and during catastrophic flooding; white arrows indicate fresh water; black arrows indicate sea water (from Zedler and Onuf 1984, with permission from Academic Press). 


\section{THE ROLE OF DISTURBANCES IN MODIFYING SALT MARSH STRUCTURE AND FUNCTION}

The dynamics of species distributions and growth rates have been documented in detail for the salt marsh of Tijuana Esluary. A general understanding of what controls invasion and extinction of species at the ecosystem scale has developed, as well as an ability to predict expansions and declines at the population scale. Catastrophic events, though destructive in many ways, are scientifically valuable. Their effects have been documented through an extensive monitoring program that began as a survey of cordgrass habitats in 1979 and has continued to date. This chapter provides extensive evidence of the estuary's temporal variability and indicates why no single year of data, or general attributes such as productivity or biomass, can fully characterize the salt marsh ecosystem.

\subsection{MONITORING PROGRAM}

The lower salt marsh has been sampled consistently at approximately 100 stations along eight transects (Figure 5.1). The exact number of stations varied slightly with our ability to relocate station markers and our need to track expanding cordgrass clones. The transects were set up to characterize the cordgrass community; thus they extended from upper distributional limits toward channels. In all cases, transects were named for the nearest Army Corps of Engineers benchmark (e.g., TJE-31).

In 1984, the monitoring program was expanded to include a larger proportion of the marsh plain. An additional 115 stations were set up to extend from the upper distributional limit of cordgrass inland. A topographic survey then showed that the more inland areas were still within the range of elevations included in the lower marsh transects (Table 5.1). This emphasizes that the distribution of cordgrass is not entirely predictable from elevation. Other factors, including competition by succulent species, limit the occurrence of cordgrass, and the monitoring program has helped to elucidate these and other distributional patterns.

Measurements taken at the monitoring stations included periodic measures of elevation relative to Army Corps of Engineers benchmarks. Each April, soil salinity was measured in samples near all stations. In the lower marsh, interstitial soil water was collected by expressing soil water (from 0 to $10 \mathrm{~cm}$ depth) through filter paper onto a salinity refractometer. In the mid-elevation marsh, the drier soil samples $0-10 \mathrm{~cm}$ depth) were collected and taken to the laboratory, where uniform soil pastes were made and measured with a conductivity meter (Richards 1954). In September, soil salinity sampling was repeated and vegetation measured. Cordgrass was assessed by measuring heights of stems within $0.25-\mathrm{m}^{2}$ circular quadrats (or $25 \%$ of that area if densities were too high for complete measurements). Flowering stems were noted; live and dead stems were counted. The percent cover of each of the other species present was estimated within cover classes ( $<1 \%, 1 \%$ $5 \%, \quad 6 \%-25 \%, \quad 26 \%-50 \%, \quad 51 \%-75 \%$, $76 \%-100 \%)$. 


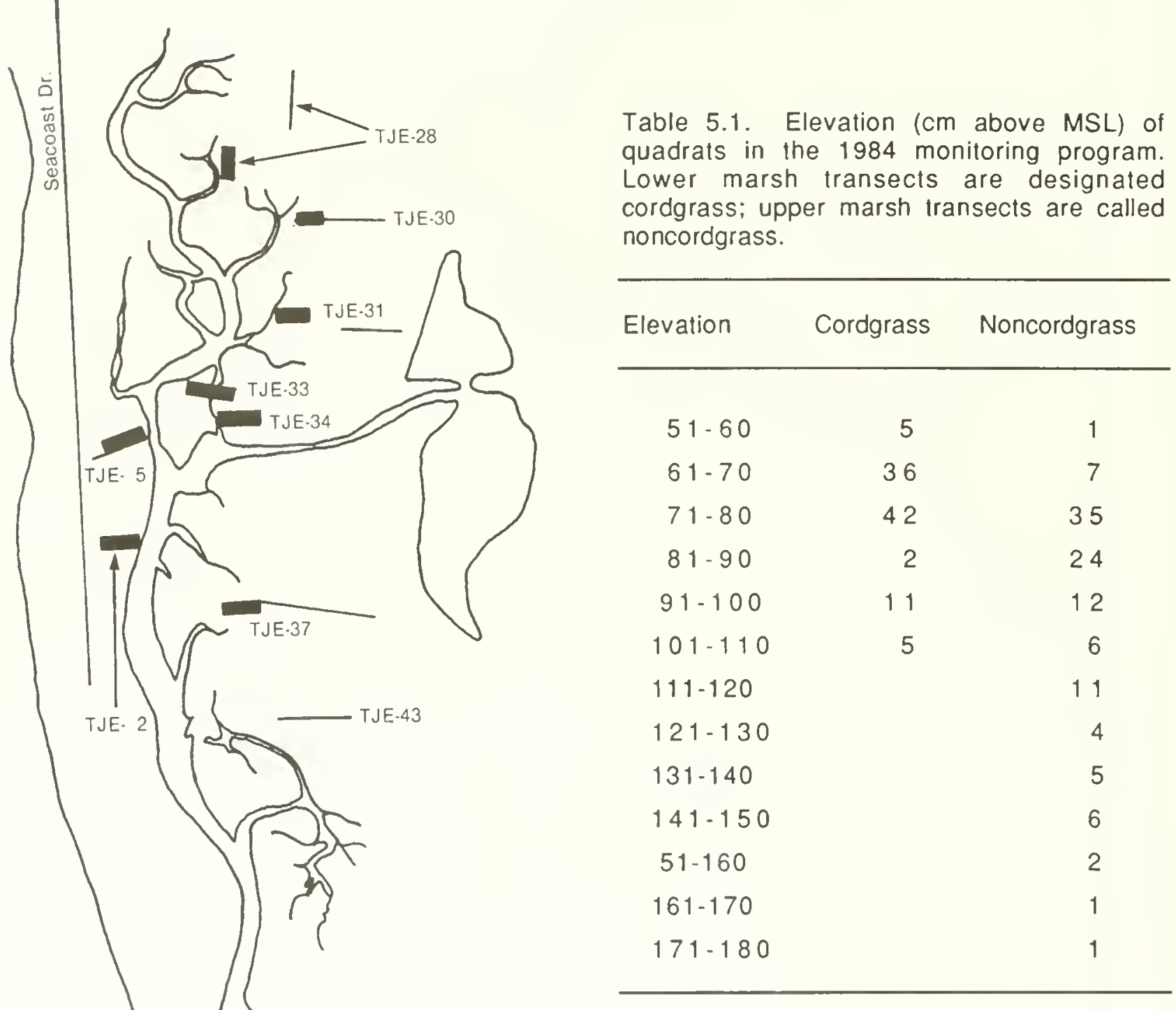

transects dominated by cordgrass ("lower marsh") $n=102$ stations monitored since 1979

transects dominated by succulents ("upper marsh") 115 stations established in 1984 .

Figure 5.1. Map of lower and upper marsh monitoring transects at Tijuana Estuary. Wide lines $=$ transects dominated by cordgrass ("lower marsh") $; n=102$ stations monitored since 1979. Thin lines $=$ transects dominated by succulents ("upper marsh"); $n=115$ stations established in 1984.

Table 5.1. Elevation (cm above MSL) of quadrats in the 1984 monitoring program. Lower marsh iransects are designated cordgrass; upper marsh Iransects are called noncordgrass.

Elevation Cordgrass Noncordgrass

$\begin{array}{lrr}51-60 & 5 & 1 \\ 61-70 & 36 & 7 \\ 71-80 & 42 & 35 \\ 81-90 & 2 & 24 \\ 91-100 & 11 & 12 \\ 101-110 & 5 & 6 \\ 111-120 & & 11 \\ 121-130 & & 4 \\ 131-140 & & 5 \\ 141-150 & & 2 \\ 51-160 & & 1 \\ 161-170 & & 1 \\ 171-180 & & \end{array}$

\subsection{PHYSICAL CHANGES FOUOWING ECOSYSTEM-WIDE DISTURBANCES}

\subsubsection{Soil Salinity Changes}

Interstitial soil salinities, measured annually in September, indicate that the lower marsh is usually hypersaline, i.e., more saline than sea water (Figure 5.2). Additional data from April of each year help to show the effect of winter rainfall, although the salinity minimum may not always be depicted by the April sampling date. Long-term records show the following:

- Soil salinity dropped to $15 \mathrm{ppt}$ in April 1980, after major flooding in both January and February. The minimum soil salinity may have been lower and earlier than measured. 
Evaporation was no doubt high throughout the spring (Section 2.2) and summer, making soils hypersaline by September 1980; thus the period of brackish soils was short-lived.

- Soil salinity was again low (30 ppt) in April 1983, when rainfall occurred late in spring. The average for April underestimated salinities later in the growing season. Covin (1984) sampled his experimental plots in the lower marsh and documented mean salinities of $31 \mathrm{ppt}$ in April, $29 \mathrm{ppt}$ in May, $39 \mathrm{ppt}$ in June, $33 \mathrm{ppt}$ in August and $34 \mathrm{ppt}$ in September. Major influxes of fresh water from Rodriguez Dam occurred throughout the growing season (IBWC 1983) that dropped channel water salinities to zero in August (Zedler et al. 1984a).

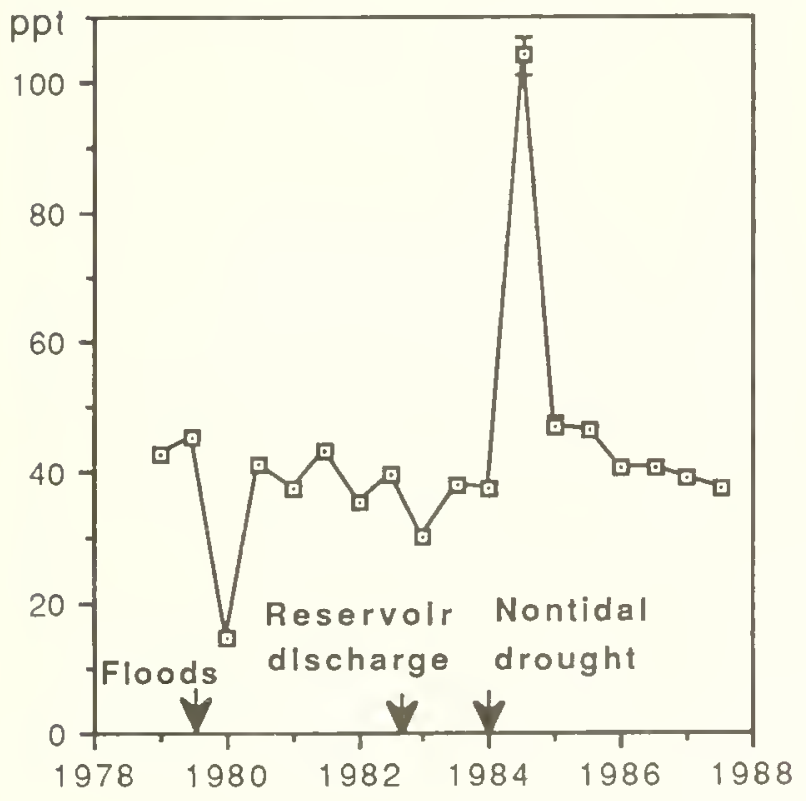

Figure 5.2. Changes in interstitial soil salinity in the cordgrass-dominated monitoring stations $(n=102)$. Data are parts per thousand (ppt) in April, following winter rainfall, and in September, following the long dry season. Samples are from the top $10 \mathrm{~cm}$ of soil. Vertical bars (mostly too narrow to show) are \pm 1 standard error.
- An average soil salinity of $104 \mathrm{ppt}$ in September 1984 resulted from estuarine closure in April 1984 followed by evaporation throughout the hot, dry summer. Again, this is an underestimate of salinity, because several readings exceeded the 0-150 ppt refractometer scale. Soil moisture at the end of summer was extremely low; channels were dried and cracked. The water table was $30 \mathrm{~cm}$ below the surface on May 31, 1984, and more than $75 \mathrm{~cm}$ below the surface on October 9, 1984.

\subsubsection{Sedimentation in the Salt Marsh}

The monitoring program tracked changes in elevation within Oneonta Slough, and these are reported below. A larger view of the impacts of flooding in 1980 followed an evaluation of aerial photos before (1976) and after (1986) the catastrophic flood (Williams and Swanson 1987). Results of that analysis are presented in Chapter 6, along with plans for removing sediments and restoring tidal flushing to the southern half of the estuary. Because Oneonta Slough is not directly in the path of the river or the steep canyons that abut Mexico, most of the sediments did not reach the cordgrass marsh. In fact, the persistence of the remaining cordgrass marsh is a function of its location and greater protection from sedimentation events. Williams and Swanson (1987) estimated that up to $2 \mathrm{~m}$ of sediments were deposited at the foot of Goat Canyon.

Elevations within the cordgrass marsh increased an average of $5 \mathrm{~cm}$ after the 1980 flood (Table 5.2). Most of the accretion was due to sediment deposition, but rafts of wood and plastic also accumulated in the lower marsh. Later, during the 1983 winter, the estuary mouth closed briefly and a large volume of sea water was impounded for several days. Sea levels were much higher during the January 1983 storm than during previous tidal maxima (Figure 2.2; Cayan and Flick 1985). Debris that had accumulated in 1980 floated to the high ground along the east edge of the salt marsh. 
Additional changes in elevation no doubt occurred with drying and shrinkage of the clay-dominated soils. Resurvey of the marsh elevations in August 1984 (Table 5.2) documented elevations similar to pre-1980 levels for all but transect TJE-2, which is closest to the area of maximum channel sedimentation. There, an increase of $28 \mathrm{~cm}$ appears to have been caused by sand and mud deposited during the same winter storm that moved much of the coastal dune into the estuarine channels. These before/after data document local sedimentation rates during that extreme event.

Caution in interpretating these elevation data is needed, since all are keyed to Army Corps of Engineers benchmarks that have not been professionally resurveyed. Whether or not the swelling and shrinkage of the marsh surface affects the positioning of these metalpipe benchmarks is unknown, as is the effect of local shifts due to subsidence (e.g., following groundwater pumping) or tectonic activily.

Table 5.2. Changes in elevation in the lower marsh before flooding (1979), after flooding (1980), and after sea storms (1984). Data are mean elevation (cm NGVD).

$\begin{array}{llll}\text { Transect } \quad 1979 & 1980 & 1984\end{array}$

\begin{tabular}{lrrr} 
TJE-2 & 66 & 71 & 99 \\
TJE-5 & no data & 97 & 96 \\
TJE-28 & 56 & 64 & 62 \\
TJE-30 & 66 & 73 & 71 \\
TJE-31 & 70 & 74 & 74 \\
TJE-33 & 67 & 70 & 68 \\
TJE-34 & 72 & 82 & 73 \\
IJE-37 & $\underline{67}$ & $\underline{67}$ & $\underline{67}$ \\
Average & 67 & 72 & 74 \\
\hline
\end{tabular}

\subsection{EFFECTS OF MAJOR DISTURBANCES ON SALT MARSH COMPOSITION}

For southern California, rare events are very important to overall wetland structure and functioning (Zedler and Onuf 1984). This section focuses on the role of extreme conditions in controlling the most basic structural feature of a plant community: its species composition. The presence of a species is determined first by its ability to establish and second by its ability to persist. It is hypothesized that germination and establishment are limited to the "low salinity gap" that follows winter rainfall, and that expansion and persistence are limited by the environmental stresses of hypersaline drought and/or excessive inundation.

At Tijuana Estuary, the salt marsh monitoring program begun in 1979 was critical for documenting increased growth, vegetative expansion, and seedling establishment of cordgrass (Zedler 1983b) following the 1980 flood. Associated field research projects that were suggested by the monitoring program have in turn identified causes of observed vegetation changes.

\subsubsection{Dynamics of the Cordgrass Marsh}

Cordgrass and its associated succulents underwent tremendous variation in growth and distribution between 1979 and 1988 . The changes were neither cyclic nor predictable from past understandings of salt marsh ecology. The vegetation dynamics appear to be related to both salinity and elevation changes that occurred between 1979 and 1985.

From 1979 to 1983, the distribution of cordgrass was relatively constant (Figure 5.3). Debris deposited by the 1980 flood eliminated some patches of cordgrass through smothering, but there was some progression landward, such that the net decrease in occurrence was small. Then, during the 1984 drought, there was substantial mortality of cordgrass, which was severe at the lowest elevations. Each tidal creek was lined with a band of dead cordgrass. The following year, 


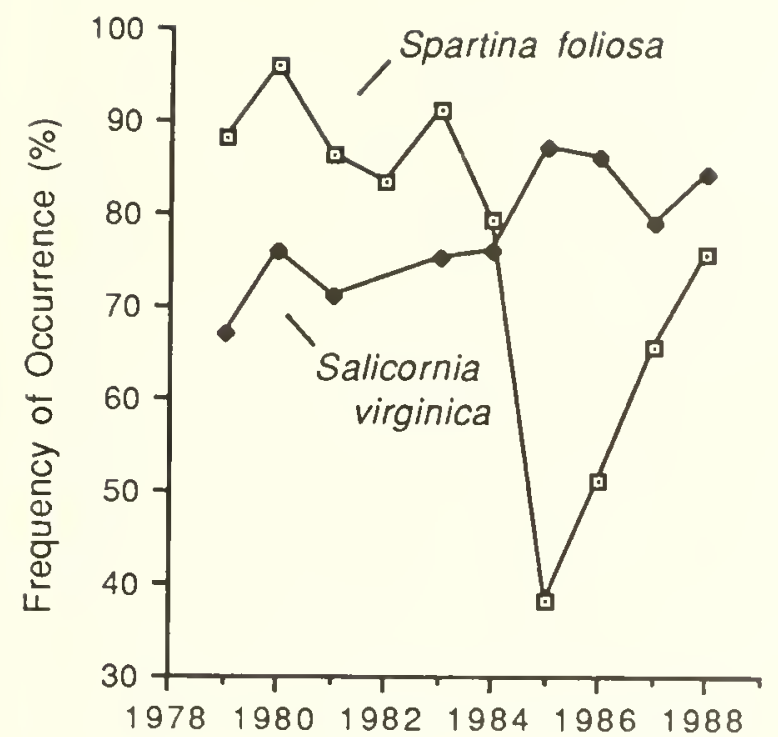

Figure 5.3. Frequency of occurrence of cordgrass (Spartina foliosa) and pickleweed (Salicornia virginica) in original low-marsh sampling stations ( $n=102)$ from 1979 through 1988. Data are from September of each year. The estuary was nontidal for 8 months during 1984.

plants that still had some green leaf material were clearly dead, and the annual census showed minimum occurrences. The widespread pattern of mortality was unprecedented in our data base, and there is every reason to conclude that it was caused by drought and hypersalinity. Recovery of the cordgrass did not immediately follow the restoration of tidal flows, which was completed in December of 1984. After four years, the species had not quite regained its average frequency before closure.

Pickleweed (Salicornia virginica) was the second most abundant species in the lower marsh, but its occurrence changed little from 1979-1984 (Figure 5.3). Afler closure, however, there was a gradual increase in the distribution of the species. The habitat changed in ways that were not documented; this expansion is not explained by soil salinity. Perhaps the one-time reduction in waterlogging during 1984 removed barriers to establishment, and once mature plants were present, they were able to persist.

Species interactions may explain some of the patterns of occurrence for cordgrass and pickleweed, although data other than occurrence are needed to test their potential interactions. Biomass data are useful measures of plant abundance, but sampling for biomass is very destructive, especially at permanent monitoring stations. Instead, we use surrogates of biomass. Cordgrass is sampled as the total stem length (sum of all plants heights in a quadrat). The correlation between cordgrass TSL and dry weight is significant for September data at Tijuana Estuary $(r=0.85, n=104, p<0.001)$. Thus, it provides a good, nondestructive estimate of end-of-season live aboveground biomass. Because pickleweed is highly branched and often trailing, we assess its abundance by estimaîing cover in standard classes, rather than attempting to count stems. This is a crude measure, so only large changes in cover can be identified.

Cordgrass had increased TSL in both the 1980 and 1983 flood years and minimal TSL in 1985, as averaged for stations where it occurred (Figure 5.4). The specific effects of flooding and nontidal drought are explored in greater detail in section 5.4. Where pickleweed occurred, it was low in cover in both 1980 and 1983. After the 1984 period of nontidal drought, pickleweed reached its maximum cover, with 62 quadrats having $>75 \%$ cover in 1985 . This species changed little in its spatial distribution (Figure 5.3); instead it changed in growth, a finding that is consistent with earlier suggestions that pickleweed is a highly tolerant species capable of survival in a wide variety of salinity and moisture conditions (Zedler 1982b). Expansion in 1985 occurred in many areas that were previously occupied by cordgrass.

Competitive interaction probably enhanced the effect of nontidal drought in 1984, as pickleweed is known to reduce cordgrass growth within its range of overlap at Tijuana Estuary (Covin 1984, Griswold 1988). 


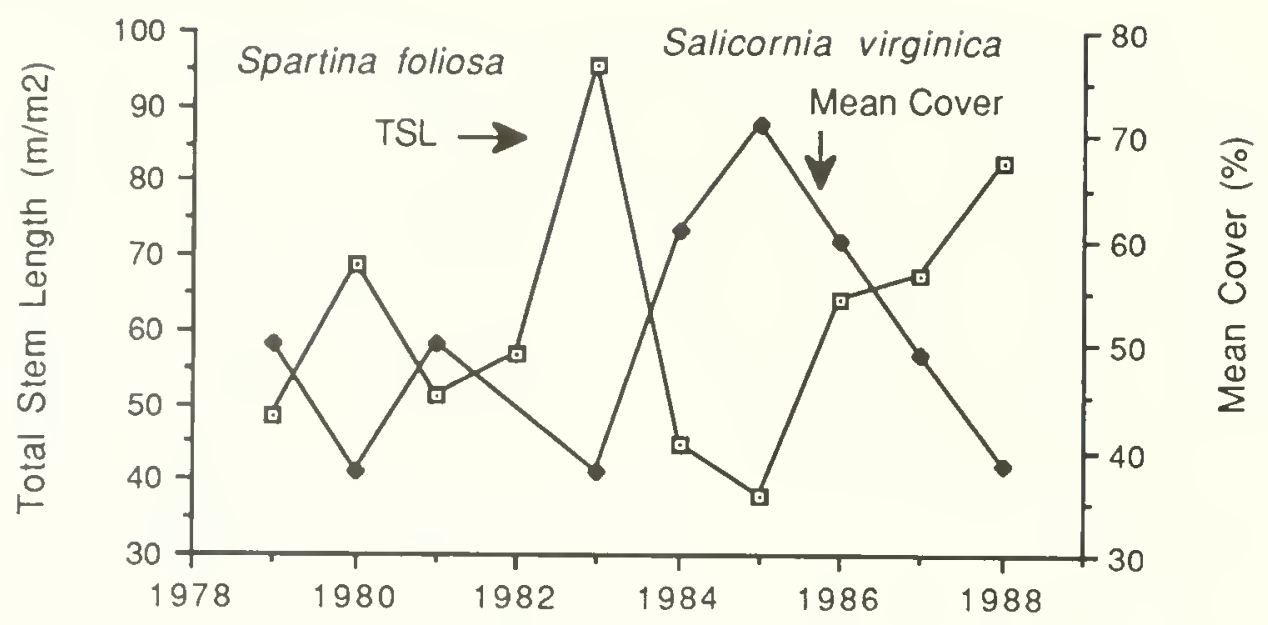

Figure 5.4. Reciprocal shifts in the abundance of cordgrass (Spartina foliosa) and pickleweed (Salicornia virginica) over the 10-year monitoring program. Flooding occurred in 1980 and 1983; nontidal drought occurred in 1984. Data are from the original 102 lower-marsh sampling stations, with means only for quadrats where the respective species occurred $(n<102)$. TSL $=$ total stem length.

Pickleweed may thus have slowed the recovery of cordgrass occurrences (Figure 5.3), even though it appears not to have slowed its biomass recovery in stations where it managed to re-invade (Figure 5.4).

The return of tidal conditions in 1985 was followed by a gradual recovery in cordgrass total stem length and pickleweed cover. Interestingly, cordgrass continued to increase in TSL to a new high in 1988 (note that means are for stations of occurrence only). Thus, even though the distribution of cordgrass was far more restricted than in 1979-83, the growing conditions were better where it occurred. Likewise, although pickleweed expanded its distribution after 1984, its average cover declined annually thereafter. It is likely that dredging in 1987 (Entrix et al. 1991) increased overall tidal flows, which should have favored cordgrass. It is unlikely that cordgrass outcompeted pickleweed to force its decline. Nor is it likely that these 1986-88 trends will continue. This will be tested with the 5-year recensus in 1993 (see plan in Section 5.5).

\subsubsection{Responses of the Mid-Elevation Marsh to Nontidal Drought}

There were several changes in the midelevation marsh plain, which is dominated by pickleweed. The 1984 expansion of the monitoring program to include 115 quadrats beyond the cordgrass habitat provided an opportunity to compare species distributions over a much larger spatial scale, as had been done in 1974 (a sample of 357 quadrats across the marsh plain, Zedler 1977). With data across the marsh plain, it was possible to document species compositional changes belween 1974 and 1984. Additional information was obtained in 58 stations used for productivity measurement in 1976 (Winfield 1980) and 9 quadrats along one transect used for a study of annual pickleweed (Salicornia bigelovii) in 1975 (Zedler 1975). While less extensive, these interim censuses helped to determine when compositional changes occurred. All sampling assessed species composition with the same cover classes and $0.25-\mathrm{m}^{2}$ circular quadrats, so that data are readily comparable. 
Some of the compositional differences between 1974 and 1984 were probably due to sampling in different locations. The 1974 data set included three transects, located at TJE-36, 40, and 43, and the 1984 data set included a larger proportion of samples from cordgrass-dominated areas. The higher frequency of cordgrass in 1984 is a consequence of more intensive sampling, rather than a real increase in the marsh. For these reasons, the 10-year comparison ascribes significance only to large changes in occurrence or cover. If nontidal drought affected the salt marsh, the greatest impact should have been on shallow-rooted species, especially annuals. Species known to have broad ecological tolerance as adults (e.g., the perennial pickleweed and alkali heath, Frankenia grandifolia) should have declined little in response to nontidal drought.

Most notable in the 10-year comparison are the absences of annual pickleweed (Salicornia bigelovii) and sea-blite (Suaeda esteroa, formerly called S. californica) in the 1984 data. Annual pickleweed was a dominant component of the marsh in $1974 \quad 64 \%$ frequency), as well as during the 1976 productivity study (Chapter 4). During a 1975 population study of annual pickleweed, its densities exceeded $4,000 / \mathrm{m}^{2}$. In spring 1984, the species was observed in seedling stage, although densities were not particularly great. These seedlings did not survive the nontidal spring and summer; no plants were seen in any of the monitored quadrats ( $n=215$ quadrats) in September 1984. Except for a tiny patch located near TJE-28, the population was eliminated at Tijuana Esluary. That small patch has persisted through 1991, and a second sighting occurred near the mouth, which indicates that the species has not been extirpated. Yet its distribution and influence on the marsh are greatly diminished. The decline was restricted to Tijuana Estuary, as annual pickleweed remained abundant at the tidally flushed marsh in Mission Bay, San Diego. Thus, the nontidal period, which coincided with a dry year, was the cause of extreme mortality, not only of the seedlings that germinated in early 1984 , but also of the seed bank, which has never recovered.

A second species also declined during 1984. The sea-blite is a short-lived perennial that occurred in $37 \%$ of the quadrats sampled in 1974 but in only one of those sampled in 1984. Sea-blite was present in the 1976 productivity study and was commonly seen up until 1984. The large change in frequency documents a significant decline, and we attribute it to the nontidal drought. The fact that sea-blite is a shortlived plant without a well-developed root syslem (Purer 1942) may explain its susceptibility to drought. Likewise, rooting depth and rool development limit survival of young seedlings.

Pickleweed and alkali heath remained abundant through the nontidal period, supporting the hypothesis that perennial species are drought tolerant. Pickleweed was the dominant species throughout the marsh in both 1974 (Zedler 1977) and 1984 (Table 5.3). Alkali heath was also very tolerant of the nontidal conditions. Belween 80 and 110 $\mathrm{cm}$ MSL, alkali heath was over $80 \%-90 \%$ frequent in 1974, and it persisted with frequencies of $60 \%-85 \%$ during 1984 .

Compared to the near extinctions of annual pickleweed and sea-blite, the longer-lived species were much less affected by the prolonged period with neither tidal flushing nor rainfall. Mature, long-lived perennials may be able to track a declining water table by extending their roots further into the substrate. Both the perennial pickleweed and alkali heath are frequent and high in biomass at Los Pefíasquitos Lagoon, where tidal flushing has been intermittent over the past several decades (Purer 1942; Bradshaw 1968; Carpelan 1969; Zedler et al. 1980). The tolerance of mature perennials to extreme environmental conditions exceeds that of species that rely on seed germination and establishment for persistence. 
Table 5.3. Change in pickleweed canopy cover in cordgrass transects from 1979 to 1984 (no data in 1982). The Kolmogorov-Smirnov Iwo-sample lest was used to compare cumulative distributions for consecutive years. The 1981-83 comparison was not significant; all others were different at the $10 \%$ level $(p<0.1)$.

\begin{tabular}{crrrrrr}
\hline & \multicolumn{7}{c}{ Number of quadrats per cover class } \\
Cover class & 1979 & 1980 & 1981 & 1983 & 1984 & 1985 \\
$0 \%$ & 32 & 23 & 24 & 26 & 23 & 12 \\
$<1 \%$ & 0 & 7 & 4 & 6 & 2 & 2 \\
$1-5 \%$ & 5 & 14 & 3 & 12 & 1 & 4 \\
$6-25 \%$ & 15 & 11 & 14 & 19 & 8 & 6 \\
$26-50 \%$ & 14 & 4 & 13 & 9 & 17 & 5 \\
$51-75 \%$ & 12 & 42 & 15 & 16 & 17 & 10 \\
$76-100 \%$ & 22 & 0 & 23 & 15 & 33 & 62 \\
\hline Mean covera & $50 \%$ & $38 \%$ & $50 \%$ & $38 \%$ & $61 \%$ & $71 \%$ \\
Total number & \multicolumn{7}{c}{5} & & & & & \\
of occurrences & 68 & 78 & 72 & 77 & 78 & 89 \\
\hline
\end{tabular}

a Mean cover was calculated from cover class midpoints using quadrats where pickleweed occurred (0's omitted).

Both annual pickleweed and sea-blite are good invaders. In 1985, both species appeared in abundance on newly dredged habitat at Sweetwater Marsh (San Diego Bay), where the California Transportation Department has a major marsh restoration project. However, recovery of both species has been slow at Tijuana Estuary. First, the seed bank was depleted, because many seeds germinated in 1984 and died before reaching maturity. Second, the predrought abundance of annual pickleweed was related to an open canopy of saltwort (Batis maritima; Zedler 1977). After the drought, the canopy of saltwort closed (total cover averaged only $40 \%$ for all elevations of occurrence in 1984). Like the perennial pickleweed, saltwort appears to have increased its biomass during estuary closure. These two hypotheses of reduced seed bank and competitive effects of the overstory were later tested in a field experiment. The results (Covin and Zedler, unpubl. data) support the hypothesis that annual pickleweed died out because its seed bank was eliminated and that a dense canopy of perennial pickleweed would have limited its reestablishment.

It is likely that expansion and shrinkage of species distributions is the norm for the region's highly dynamic wellands. The estuary's history of variable rainfall and streamflow, fluctuating sea levels, and alternating conditions of good and sluggish tidal flow, all suggest that the abundance and distributional limits of marsh species should also vary. However, the combination of severe environmental stresses, such as drought combined with estuary closure, is probably rare. Thus, local extinction is not viewed as a common event for this estuary. Species richness in the region's wetlands is high for systems with good tidal flushing and low for systems that frequently close to tides (Zedler 1982b); the near loss of annual pickleweed and sea-blite was no doubt due to a combination of events.

Similar patterns of species distributions have been documented at a Mexican site along 
Estero de Punta Banda (Ibarra-Obando 1991). A large corner of the estuary was diked to exclude tidal flushing. Ibarra-Obando compared the composition of salt marshes inside and outside the dike and documented the same changes during the same year of very low rainfall (1984). Soil salinities skyrocketed while soil moisture dropped. Perennial pickleweed flourished, and annual pickleweed and sea-blite declined sharply in both their frequency of occurrence and percent cover. Her results strongly support the above interpretation that the coincidence of nontidal drought and the decline of shortlived species is a cause-effect relationship.

Whether or not either short-lived species will recover at Tijuana Estuary depends in part on management of the estuary. Dredging reopened the estuary mouth in December 1984 and increased tidal flushing beyond what it was in 1983 (Entrix et al. 1991). Yet perennial pickleweed remains abundant and there is little open space for seedling establishment. The seed bank no doubt remains depleted. A rapid recovery of either species would require a reduction in the perennial pickleweed canopy and seeding to replenish the seed bank. Neither is recommended at this stage. Rather, studies of the importance of these species to the salt marsh biota and long-term evaluation of their (potential) expansion are suggested.

\subsubsection{Mid-Elevation Dynamics After 1984}

Extreme events have not significantly altered the monitored areas of salt marsh since tidal flushing was restored in December 1984. The 1988 sea storm altered the inlet (Webb et al. 1989) and had catastrophic impacts on the dunes (Fink 1989), but Oneonta Slough did not close and there was no interruption in tidal flushing. Data from the expanded monitoring program thus provide a new baseline record of the post-closure salt marsh.

At the whole-marsh scale, species composition appeared to be very stable from 1985 through 1988 (Figure 5.5). In 216 quadrats, the only notable shift was an

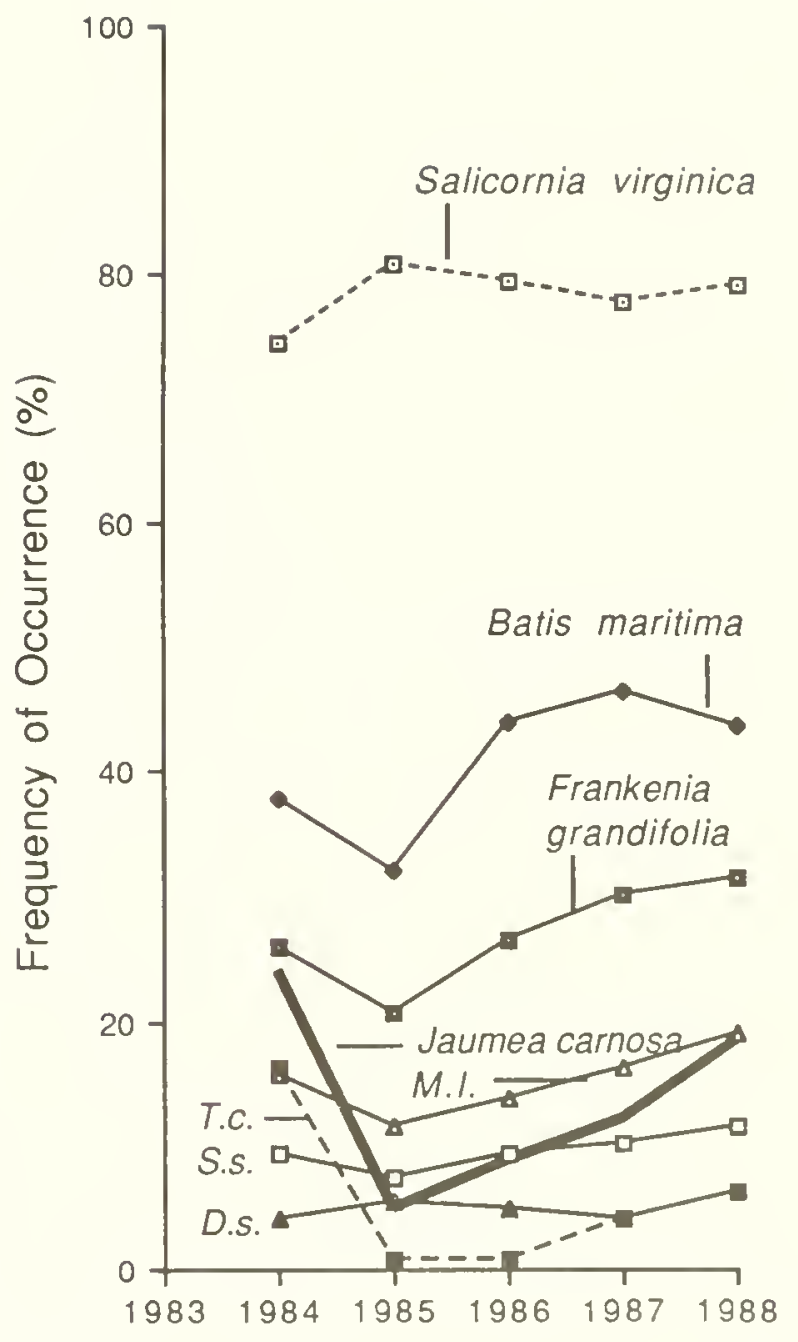

Figure 5.5. Dynamics of salt marsh vegetation (cordgrass excluded) following the 8month closure (April-mid Dec., 1984) of the ocean inlet. Data are from Griswold and Zedler (1990; $n=216$ quadrats). M.l. = Monanthochloe littoralis; T.C. = Triglochin concinnum; S.s. = Salicornia subterminalis; D.s. = Distichlis spicata.

increase in salt wort (Batis maritima) in 1986. At the individual quadrat scale, however, the marsh proved to be much more dynamic. Several species appeared and disappeared from quadrats even when their overall occurrence was nearly constant (Griswold and Zedler 1990). Perennial pickleweed (Salicornia virginica) was the most dynamic of the species, appearing and 
LOW-

disappearing much more often than was obvious from its net changes. A tendency to shift about, either through vegetative expansion or recruitment from seed, indicates high recoverability and resilience. Such species are more likely to recruit when space becomes available.

The analysis of small-scale dynamics underscores the need to sample large areas in order to represent species distributional changes. Sampling a small area that happens to coincide with quadrats undergoing local expansion or elimination may not represent the range of the species. As a correlate, sampling a large area and ignoring changes at the quadrat scale can underestimate the dynamics of species occurrences.

\subsubsection{A Conceptual Model of Compositional Changes}

Extreme events have altered wetland structure dramatically in southern California. At the same time, they have helped to reveal cause-effect relationships. Invasion and expansion of species are controlled by the annual "low-salinity gap" (Figure 5.6), which varies both in duration and degree of salinity reduction (Zedler and Beare 1986). Population declines and local extinctions are caused by drought, hypersalinity, and prolonged inundation, to which species have differential tolerance.

The species characteristic of southern California coastal wetlands do not conform to the classical separation of halophytes and glycophytes on the basis of tolerance to 0.5 ppt salinities (Waisel 1972). There is a spectrum of tolerances, and establishment is determined by the degree and duration of freshwater influence: the low-salinity gap. Salinity determines germination, while duration of the required salinity and soil moisture conditions determines seedling establishment. This is consistent with the regeneration niche concept of Grubb (1977), who hypothesized that multiple characteristics of both species and environment influence establishment. Once established,

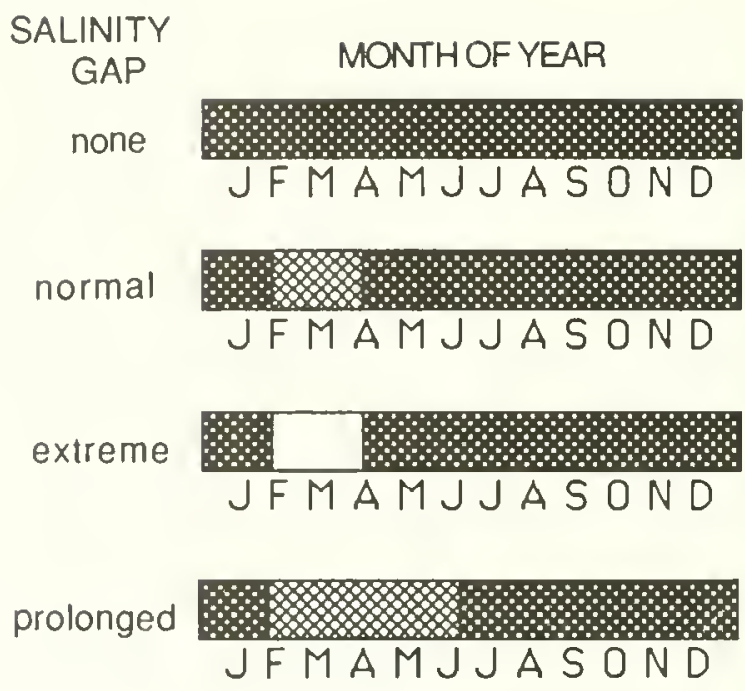

Figure 5.6. Conceptual model of low-salinity gaps in the salt marsh soil. Density of dots indicates salinity, with the usual condition being hypersaline (>40 ppt). The degree of salinity reduction and its duration determines seed germination and seedling establishment (see text).

salt marsh plant populations may persist or go extincl, depending on environmental conditions that may differ greatly from those controlling establishment.

The following is a summary of how lowsalinity gaps appear to control invasions and how extreme stresses appear to control local extinctions, based on conditions at both Tijuana Estuary and San Diego River and changes following welter and drier conditions.

- No low-salinity gap: With little or no winter rainfall, only a few of the salt marsh species (i.e., Salicornia species) are able to germinate and establish seedlings.

- Normal low-salinity gap: With typical winter rainfall, brief salinity reduction stimulates seed germination and allows seedling establishment. Species of the brackish marsh are not able to establish.

- Extreme low-salinity gap: Extreme flooding reduces salinities substantially, and 
the number of halophytes that can establish from seed increases. Cordgrass (Spartina foliosa) and spike rush (Juncus acutus) are able to expand their distributions through seedling recruitment. However, because the low-salinity gap is brief, brackish marsh species are unable to establish.

- Prolonged low-salinity gap: Artificially impounding freshwater or increasing streamflow via reservoir discharge allows a variety of fresh and brackish marsh species to germinate and become established. If they grow to rhizome stage while salinities are low, they may persist after hypersaline conditions return.

- Impoundment effects: If either fresh or saline water is impounded, inundation becomes stressful, especially if waters completely submerge the mature plants or seedlings. Species with little aerenchyma will undergo heavy mortality. Pickleweed (Salicornia virginica) dies out in areas that have prolonged periods of inundation, especially in summer. In the Netherlands, experimental studies of several halophytes indicated that warm temperatures reduce inundation tolerance (Groenendijk 1984); this is reasonable, since respiration rates would increase and growth would decline.

- Drought and hypersalinity effects: When an estuary closes to tidal flushing, soils will dry and salinities will rise simultaneously, unless rainfall or artificial discharges maintain water supplies. Most vegetativelyreproducing perennials can survive long periods of hypersalinity, perhaps by growing longer roots and tapping water stored below $0.5 \mathrm{~m}$ depth (Griswold 1988). Even though cordgrass had high mortality in 1984, its population did not go extinct at Tijuana Estuary. However, short-lived species that have shallow roots and annuals that rely on seedling recruitment will undergo heavy mortality.

Competition among species is also a factor in local extinction. The region's rather diverse plant communities may well result from the highly variable environment, because no one species has optimal environmental conditions or an indefinite competitive advantage. For example, pickleweed usually outcompetes cordgrass (Zedler 1983b; Covin 1984, Griswold 1988), but the conditions that limit cordgrass (hypersaline drought) differ from those that limit pickleweed (inundation). With prolonged flooding, pickleweed loses its advantage, and complete exclusion cannnot be achieved through competition.

\subsection{EFFECTS OF MAJOR DISTURBANCES ON CORDGRASS GROWTH}

The monitoring of cordgrass at Tijuana Estuary has tracked its responses to major flooding (1980, 1983) and drought (1984), as documented by the total stem length (TSL) data (Figure 5.4, Zedler 1983b, Zedler ef al. 1986, Zedler 1991a). In this section, the various responses of the cordgrass are explored by comparing effects on height, density, and mortality. All summaries are for stations where the species occurred (variable $\mathrm{n}$; see frequency data in Figure 5.3).

There was a significant increase in TSL in 1980 and a rapid decline in 1981. This growth response has been interpreted as an effect of reduced soil salinity that resulted from calastrophic flooding (Zedler 1983b). At the time, it was thought to indicate a maximum growth response for the site, because floodwater volumes were enormously high (the 1980 water year had 28 limes the average streamflow of previous years). On the average, plants grew over $10 \mathrm{~cm}$ taller in 1980 than the previous year (Figure 5.7). In addition, plants reached maximum heights that were $20 \mathrm{~cm}$ greater than in 1979 (Figure 5.8). The tallest plants exceeded 100 $\mathrm{cm}$.

The second major growth response occurred in 1983. In contrast to the 1980 response of increased height, the 1983 response was largely one of increased densily (Figure 5.9). Height also increased, as maximum heights averaged $90 \mathrm{~cm}$ (Figure 5.8 ), but it did not show up as an increase in mean height (Figure 5.7) because production of new, short individuals dominated the vegetation response. The high TSL in 


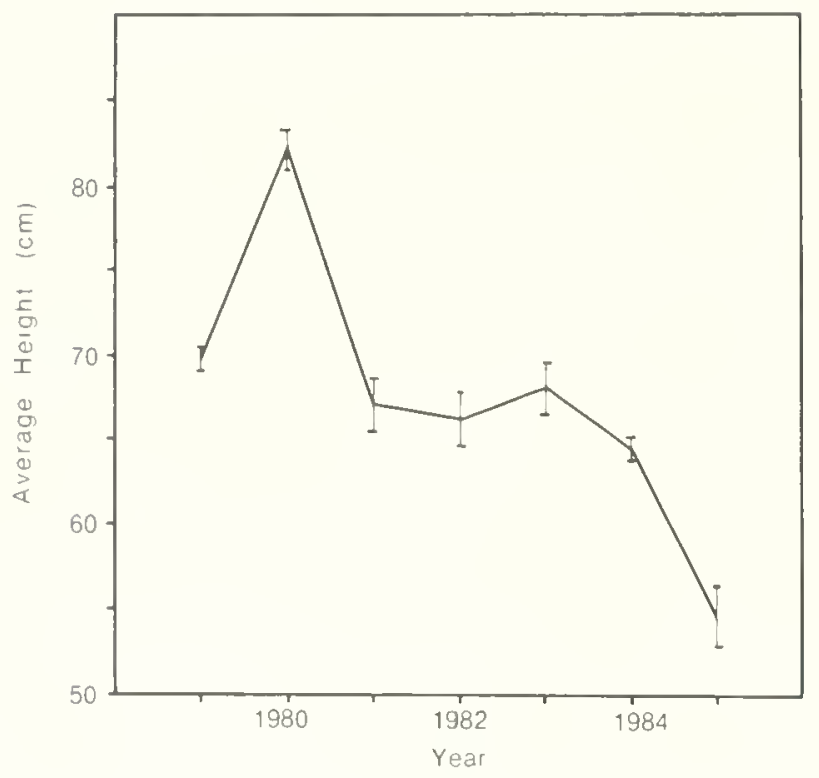

Figure 5.7. Changes in average height of cordgrass. Means are based on the total number of stems measured each year.

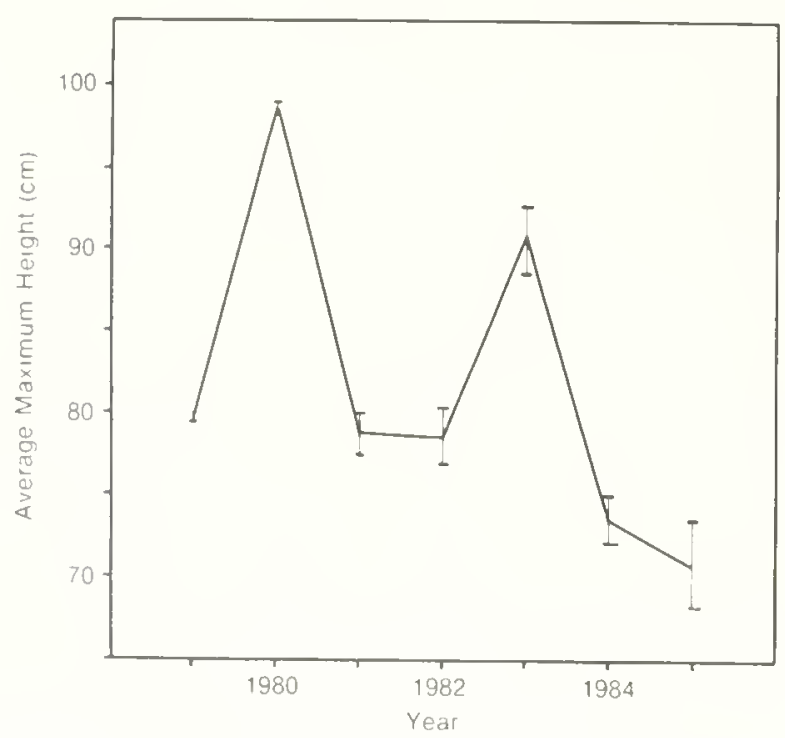

Figure 5.8. Changes in the maximum height of cordgrass. Means are from the number of quadrats in which cordgrass was present each year.

September 1983 followed freshwater influence that was of lower volume than the 1980 floodflows but of longer duration.

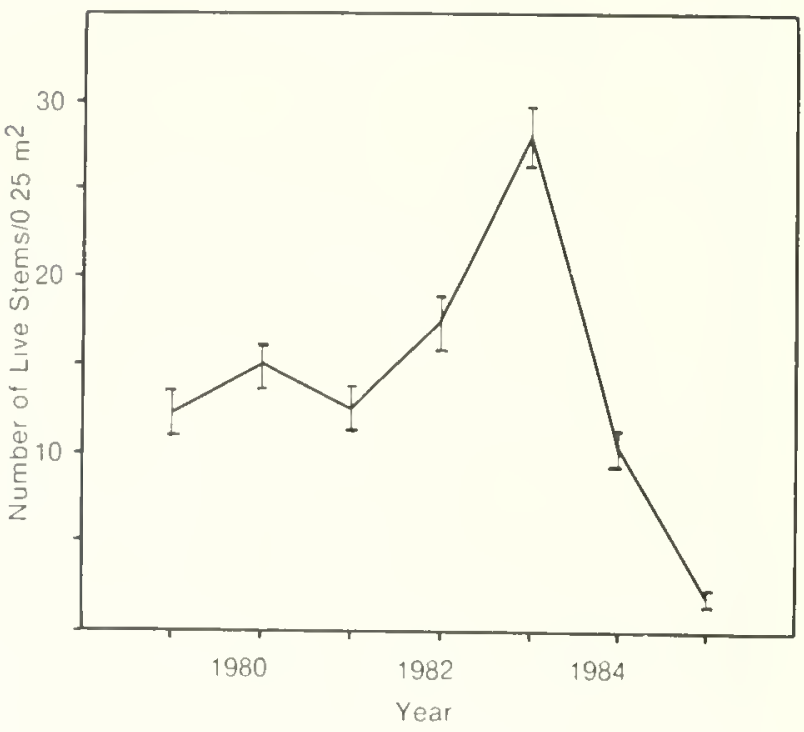

Figure 5.9. Changes in the density of cordgrass stems. Means are from the number of quadrats in which cordgrass was present each year (Figure 62).

Finally, in September 1984, we found extremely low TSL due to poor growth and heavy mortality of cordgrass following drought conditions. The effect of drought became even more apparent in 1985, when the lowest TSL was documented. Both density and height were lower than ever before recorded. The delayed reaction of cordgrass TSL measurements was due to the longevity of the plant. Individual stems live 1.5-2.0 years, and the 1984 measurements included stems with some live material from the previous growing season. By 1985, there were few plants from the previous year and few individuals from 1985, even though tidal flushing had been reinstated throughout the entire growing season.

To interpret these variations in cordgrass growth requires consideration of the effects of hydrological change on pickleweed, because pickleweed is the competitive dominant (Zedler 1982; Covin 1984) and its distribution overlaps with cordgrass throughout most of the lower marsh. Years of high pickleweed cover were 1979, 1981, and 1984-85 (Figure 5.4). These same years had low cordgrass biomass. Cordgrass TSL can be high when two conditions are met. First, 
there must be appropriate salinity, nutrients, and soil moisture; and second, there must be reduced competition from pickleweed. The latter condition appears to be associated with reduced drainage, that is, increased inundation. Two experimental studies were designed to test these ideas.

\subsubsection{Freshwater Addition in a Field Experiment}

An experimental field study was initiated in 1984 to determine how coastal wetlands would respond to increased streamflow caused by treated wastewater. The data provide a test of the above hypotheses concerning cordgrass responses to salinity reductions at different times of the year. A brief summary and pertinent findings follow from the work of Beezley and Beare (SDSU, unpubl. data).

The experiment compared year-long, winter, and summer irrigation with fresh water, all compared 10 unwatered control plots. A block experimental design was set up with replication in both cordgrass and pickleweed habitats. City water was piped to the marsh and used to fill meter-square cylinders that surrounded salt marsh vegetation. Watering began early in January 1984 and continued approximately biweekly for 7 months until the drought disturbed the experiment. Late in the experiment, watering changed soil moisture as well as the soil salinity. The drying of marsh soils, following estuary closure and high rates of evaporation created deep cracks throughoul the experimental area, and the cylinders would no longer hold water. In late May, the winterwatering treatment ended and the summerwatering treatment began. Cordgrass responses were measured as in the monitoring program; pickleweed growth was measured as increased length of tagged stems.

Four hypotheses were lested with results from the irrigation experiment. For the most part, the predictions were upheld.
- We predicted that cordgrass growth would increase wherever we added freshwater and that maximum biomass would occur with continuous watering. Plots had 394-761 $\mathrm{cm} / \mathrm{m}^{2}$ of cordgrass stems prior to watering (Table 5.4). Unwatered controls increased the least amount (mean $=834 \mathrm{~cm} / \mathrm{m}^{2}$ ) by late June, and then decreased with droughtcaused mortality. Year-long and summerwatered plots continued to increase, on the average, throughout the experiment, while winter-watered plots declined along with controls.

- We predicted that winter watering should result primarily in increased height, as had occurred following the 1980 flood. Average height of cordgrass was $40 \mathrm{~cm}$ prior to watering in January, and controls increased $10 \mathrm{~cm}$ by late June. The height response was greater with watering, but the results were not quite as predicted. By August, year-long watering had increased plants $56 \mathrm{~cm}$ and summer watering, $52 \mathrm{~cm}$, compared to $30 \mathrm{~cm}$ in winter-watered plots and $18 \mathrm{~cm}$ in controls. Winter-watered plots should have matched the year-long plots, if timing of freshwater influence were the only controlling factor. The growth response is complex and possibly modified by the unusual summer drought.

- We predicted that summer watering would increase plant density, based on the increased density of cordgrass with reduced salinities during summer 1983 (Figure 5.9). Increases in cordgrass density were greatest in the summer-watered plot 122 stems/quadrat/6 months), as predicted, while year-long and winter-watered plots were similar to controls.

- We predicted that cordgrass mortality should be lowest where soil moisture dropped gradually, based on the pattern of high cordgrass mortality in 1984 (higher around creek banks than further inland). Thus, winter- and summer-watered plants were expected to have higher mortality after plot irrigation ended than plants in unwatered control plots. All treated plots experienced 
Table 5.4. Effects of irrigating the cordgrass marsh in situ (from Zedler, Beezley, and Beare unpubl.).

\begin{tabular}{|c|c|c|c|c|c|}
\hline & \multirow[b]{2}{*}{ Block } & \multicolumn{4}{|c|}{ Watering treatmenta } \\
\hline & & Control & Yr-Long & Winter & Summer \\
\hline \multirow{3}{*}{$\begin{array}{l}\text { Jan.-June Increase } \\
\text { in Total Stem Length } \\
\left(\mathrm{cm} / 0.125 \mathrm{~m}^{2}\right)\end{array}$} & & & & & \\
\hline & 1 & 694 & 1649 & 1009 & 1858 \\
\hline & 3 & 975 & 1651 & 1168 & 1841 \\
\hline \multirow{3}{*}{$\begin{array}{l}\text { Jan.-June Increase } \\
\text { in Mean Height }(\mathrm{cm})\end{array}$} & 1 & 6 & 31 & 15 & 28 \\
\hline & 3 & 14 & 36 & 32 & 26 \\
\hline & Average & 10 & 34 & 24 & 27 \\
\hline \multirow{3}{*}{$\begin{array}{l}\text { Jan.-Aug. Increase } \\
\text { in Mean Height (cm) }\end{array}$} & 1 & 6 & 58 & 16 & 50 \\
\hline & 3 & 29 & 54 & 45 & 53 \\
\hline & Average & 18 & 56 & 30 & 52 \\
\hline \multirow{3}{*}{$\begin{array}{l}\text { Jan.-June Density } \\
\text { Change }\left(\# / 0.25 \mathrm{~m}^{2}\right)\end{array}$} & 1 & 11 & 17 & 14 & 22 \\
\hline & 3 & 13 & 14 & 12 & 23 \\
\hline & Average & 12 & 16 & 13 & 22 \\
\hline \multirow{2}{*}{$\begin{array}{l}\text { June-Aug. Density } \\
\text { Change }\left(\# / 0.25 \mathrm{~m}^{2}\right)\end{array}$} & 1 & 9 & -5 & -7 & -2 \\
\hline & 3 & -4 & -8 & -7 & -16 \\
\hline
\end{tabular}

cordgrass mortality in the last 5 weeks of the experiment, when soils dried out between waterings. However, one control plot increased in density. While evidence is scanty, there is at least a suggestion that infrequently wetted areas withstand drought better, and differential rooting depths might explain differential survival. Studies of below-ground plant growth at different intertidal elevations are needed to explain the high creek-edge mortality seen during the 1984 drought.

The importance of seedling recruitment was not addressed in these year-long experiments. Most of the dynamics of cordgrass have resulted from changes in vegetative growth.

\subsubsection{Manipulation of Inundation in Outdoor Mesocosms}

Griswold (1988) investigated the effect of inundation using meter-square mesocosms within a field research facility at Tijuana Estuary. Cordgrass and pickleweed growth were each examined in relation to inundation levels. Six rows of cordgrass were planted along a slope in nine mesocosms; six rows of pickleweed were planted in another 9 mesocosms; and water levels were maintained to inundate the lower two rows. Thus, the lower rows were saturated, the middle two rows were relatively moist $(26-27 \%$ soil moisture) and the top two rows relatively dry (22-23\% moisture). Surface soil salinity varied along with soil moisture, with the lower rows ranging from 15-20 ppt, middle, 
37-46 ppt, and upper, 59-84 ppt over the one-year experiment.

Overall, pickleweed grew better than in the nearby intertidal salt marsh, with biomass averaging over $2.5 \mathrm{~kg} / \mathrm{m}^{2}$ in the upper rows by late summer. In contrast, cordgrass biomass was lower than in the tidal salt marsh, with maximum values well under $1 \mathrm{~kg} / \mathrm{m}^{2}$. Griswold's (1988) findings support the observation that pickleweed can thrive in semitidal wetlands within the region (and in the southern arm of Tijuana Estuary), while cordgrass is restricted to fully tidal situations (and the northern arm of Tijuana Estuary). Although the mesocosms did not mimic the tidal hydrology of Tijuana Estuary, the relative growth of each species provides a test of their hypothesized differential inundation tolerance.

Cordgrass aboveground biomass decreased with elevation, in relation to the gradient of inundation and soil moisture (Figure 5.10). The pickleweed response was the opposite; biomass increased as surface soil moisture declined (Figure 5.10).

\subsubsection{Manipulation of a Competitor in a Field Experiment}

In order to test the hypothesis that pickleweed outcompetes cordgrass, Griswold (1988) set up a field experiment at Tijuana Estuary. Pickleweed was removed from replicate plots of mixed pickleweed-cordgrass vegetation. Griswold then compared the growth of cordgrass with that in control plots. The experiment was established in January 1987, and responses were documented monthly through October. By June, plots with pickleweed removed had significantly more stems of cordgrass present, supporting the hypothesis of competitive exclusion. By October, cordgrass had increased 6 times as fast in plots without pickleweed present. Average densities were $120 / \mathrm{m}^{2}$ (s.e. 29.2) without pickleweed and $36 / \mathrm{m}^{2}$ (s.e. 17.2) with pickleweed present (Griswold 1988).
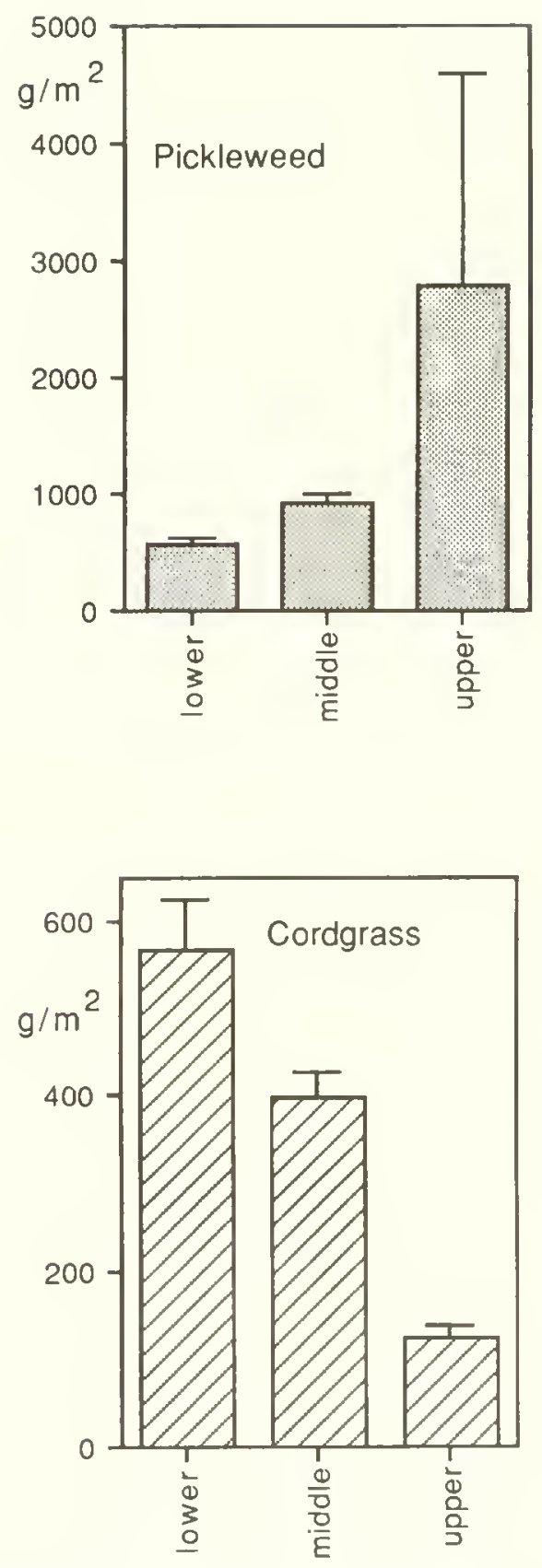

Figure 5.10. Growth of salt marsh vegetation at three elevations, which differed in inundation, soil moisture, and soil salinity. Top graph: Response of pickleweed (Salicornia virginica) aboveground biomass. Bottom: Response of cordgrass (Spartina foliosa) biomass. Data are from the outdoor mesocosm study by Griswold (1988). 


\subsubsection{Nutrient Addition Experiments}

From the first year on, the annual censusing of cordgrass documented considerable spatial variability from quadrat to quadrat and transect to transect. While strong year-to-year differences have been explained, local variations have only recently been investigated. It is now clear that nutrients and insects add to both spatial and temporal changes.

As discussed in Chapter 4, Covin (1984) found that soil nitrogen was important to cordgrass growth. His experimental manipulations showed that urea increased cordgrass growth in pure stands (although in different amounts for the two sets of plots), but not in stands mixed with pickleweed. The influence of urea on cordgrass thus depended in part on the presence of its most frequent co-occurring species, with pickleweed the better competitor for urea.

Nutrient-addition experiments also suggested that insect grazing has significant impact on cordgrass growth and densities. Covin's urea-addition plot at TJE-28 produced cordgrass with higher tissue nitrogen content than at TJE-31, and a lateseason dieback occurred on those plants. Patches of cordgrass died along that same transect after the 1980 flood. Because pickleweed was lacking, we knew that competition was not the cause. If nitrogen inputs were high at TJE-28, nitrogen uptake should have been higher, and with that, increased probability of insect attack. Research with other wetland (Onuf et al. 1977) and grassland (McNeil and Southwood 1978) vegetation has shown that insects are altracted to plants with high nitrogen concentrations and that herbivory is greater on leaves with augmented nitrogen. Clearly, these secondary effects of added nitrogen can have important effects in nature.

\subsubsection{Conclusions from Experiments}

The hypotheses that grew out of the monitoring program withstood experimental resting, and we provide the following conceptual model of the control of cordgrass growth. Cordgrass is commonly under stress due to hypersaline soils and low nitrogen supplies. Freshwater influxes to the marsh stimulate increased growth by reducing soil salinities. If the influx is from flooding, nitrogen supplies are likely to be enriched.

The timing of freshwater inflows appears to be important. When a growth stimulus occurs in winter, plants can respond by increasing their height and also density. If the influx occurs in summer, during the peak of the growing season, plants respond primarily by vegetative reproduction. From the standpoint of an individual, it is a matter of when carbon is allocated to above-versus belowground growth. The later that fresh water (and/or nitrogen) is applied, the less likely the plants will respond by increasing in height. Increased production late in the season seems to be channeled primarily to new shoots.

\subsection{THE REVISED MONITORING PROGRAM}

By 1989, the monitoring program had accumulated data from several years with catastrophic disturbances (winter flooding in 1980, late-winter flooding in 1983, El Nifio storms in 1983, and closure of the tidal inlet through most of 1984). Recovery from the flood events and from inlet closure had been documented. It was time to reevaluate the objectives of monitoring and the methods of sampling to determine whether the data being gathered were still the most appropriate for the management questions being asked.

The review led us to recognize the following shortcomings: First, the transects across the elevation gradient undersampled the lower and mid-marsh elevations and appeared to oversample the marsh plain. The time involved in finding and sampling 215 stations no longer seemed warranted by the amount of information gained.

Second, studies of cordgrass at San Diego Bay (Langis et al. 1991, Zedler 1991, Zedler, in review) indicated the need for detailed data on interannual variability in 
cordgrass canopy architecture to characterize habitats that could and could not support the endangered clapper raiis. Widespread sampling had documented major changes to the distribution of cordgrass following extreme events, but with those responses in the record, it became more important io understand finer-scale responses to less dramatic variations in the environment. The need to track canopy architecture changes suggested intensive sampling of selected purecordgrass sites.

Third, the use of cover classes was adequate only for assessing gross change in species abundance (such as followed flooding or tidal closure). Other year-to-year variations could not be detected, and it was unclear if the reason was their absence or the crude sampling regime. Third, soil salinities proved to be very consistent among stations of similar elevation, thus suggesting a subsampling program and greater efficiency. Lack of data on salinities at depth was also noted.

Fourth, it became desirable to compare salt marsh structure at locations that represented a greater range of tidal flushing conditions, since a tidal restoration program was being developed for the estuary. More information on the upper marsh was needed. Throughout the reevaluation, it was recognized that the ten-year record for the original stations and the five-year record for the additional 115 stations should not be abandoned.

A revised monitoring program was designed to respond to all the above concerns. It is adaptive in that as new problems or methods arise, the program expands to accommodate these concerns, and as sampling is shown to be unnecessary or inadequate, it is dropped or modified. It is hierarchical in that the larger areas are sampled less frequently, and selected sites are studied more intensively and more often.

Intensive sampling was indicated for three segments of the elevation gradient at Tijuana Estuary: lower, middle, and upper marsh elevations. A lower marsh community with cordgrass is obvious at the estuary, since the dominant plant is a clonal species with relatively discrete boundaries. However, only the lowest elevations have pure cordgrass; elsewhere both pickleweed and saltwort cooccur, and before 1984, the annual pickleweed was a common associate. To evaluate the dynamics of cordgrass, the interference of other species was considered undesirable. Hence, the lower-marsh transects were placed in pure cordgrass at the lowest elevations, along tidal creeks.

An upper-elevation glasswort and shore grass-dominated community is also obvious at Tijuana Estuary. The bushy, densely branched glasswort often forms a relatively discrete lower boundary that suggests a clear zonation. Two species of the upper marsh have narrow elevation ranges and rarely extend below the distribution of glasswort; these are the salt marsh bird's beak and Atriplex watsonii. Since neither is abundant, they fail to reinforce the concept of distinct species association. In fact, each marsh species has a unique distribution, such that the marsh vegetation is not readily characterized as forming discrete zones (Zedler 1977). Still, the change in marsh canopy architecture that accompanies the shift to glasswort dominance at higher elevation may well be important to birds and other animals that use the marsh. Spider webs, for example, are very abundant in the upper canopy of glasswort, which is rarely inundated by tides. For this reason, upper-elevation transects were placed in marsh dominated by glasswort.

The elevations befween the upper limit of cordgrass and the lower limit of glasswort are dominated by pickleweed, which does not have discrete upper or lower boundaries. The largest area of the salt marsh has this intermediate elevation, which forms the marsh plain. The middle marsh is characterized by the absence of cordgrass and glasswort, rather than by the presence of pickleweed, which overlaps with both the lower and upper marsh dominants. Cooccurring with pickleweed are mosi of the region's salt marsh species (Figure 3.2).

Four stations were chosen to represent each of the marsh elevation transects (Figure 5.11). The four stations differ in distance 


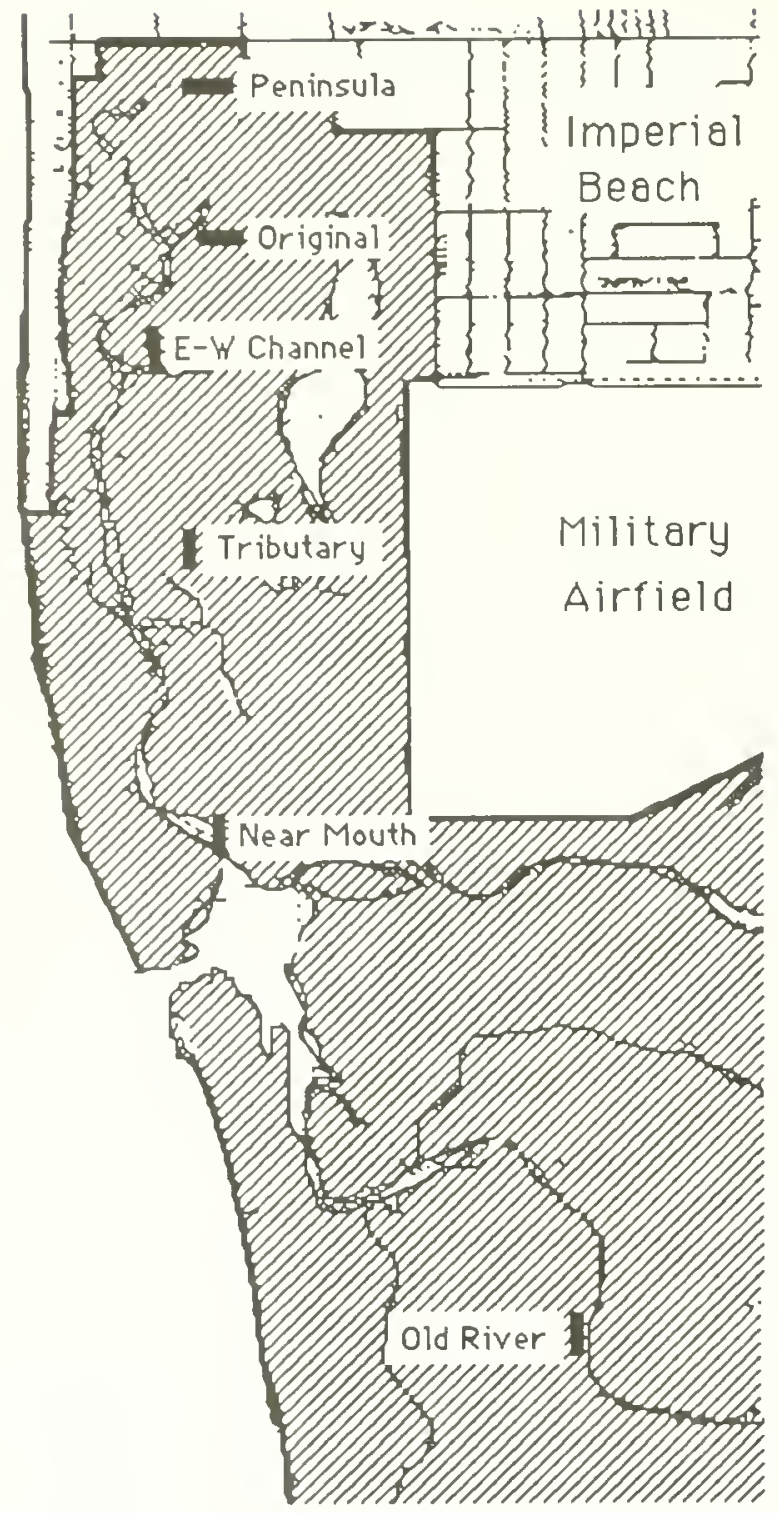

Figure 5.11. Sampling stations for the revised salt marsh monitoring program. Cordgrass is now monitored annually at the four northernmost stations (Peninsula, Original, E-W Channel, and Tributary). Midelevation and upper-elevation transects were placed at the Peninsula, Original, Near Mouth and Old River stations. Each station includes one or more transects of $20-\mathrm{m}$ length. There are 4 transects for each of the habitats (lower, mid-and upper intertidal elevation). from the ocean inlet. The south arm of Tijuana Estuary is included in comparisons of middle and upper elevation transects. Since cordgrass is restricted to the northern arm, all four lower-marsh transects are located along Oneonta Slough.

At each site, a 20-m transect is located along the elevation contour. Cover of each species is recorded to the nearest $10 \mathrm{~cm}$, within 1-m intervals. Bare space is recorded separately. At $2-m$ intervals $(n=10)$ within the lower marsh, a circular quadrat $\left(0.10 \mathrm{~m}^{2}\right)$ is used to select cordgrass stems for height measurements. At $10-\mathrm{m}$ intervals (i.e., 3 per transect), soil salinity is measured at 10 and $30 \mathrm{~cm}$ depth. Soils in the lower and middle transects are generally moist enough to express soil water onto the refractometer. Drier soil samples at the upper transects are collected, returned to the laboratory, and mixed with deionized water to form a uniform soil paste before expressing the filtrate onto the refractometer. The upper marsh data are thus representative of soil salinities that follow rainfall, while the lower and middle marsh data represent ambient conditions.

The above sampling program began in 1989 and, as of this 1991 writing, has characterized the marsh soils and vegetation during a period of relatively similar environmental conditions. Sewage flows from Mexico, which averaged up to 13 MGD from 1986 on, were terminated in early October 1991. The three-year data base is thus a detailed summary of conditions with sewage inflows and before tidal restoration.

The 215 stations will be sampled at 5 year intervals, with the next effort to occur in 1993. Cover estimates will be omitted for this broad survey, as will measurements of cordgrass height. Species composition will be reexamined by sampling for occurrence. Soil salinities will be subsampled (e.g., every 5 th station) to increase efficiency. In the event of an environmental catastrophe (flood, inlet closure, etc.), more frequent resampling would be in order (pending funding). 
5.6 RESULTS OF THE NEW ADAPTIVE MONITORING PROGRAM, 1989-1991

The revised salt marsh monitoring program began in September 1989. The four lower-elevation stations are all located in Oneonta Slough, coinciding with the occurrence of cordgrass (Figure 5.11). The upper- and middle-elevation stations are more broadly spaced; one is near the mouth of the estuary, and one is in the south arm. There are no obvious differences in soil salinity between the latter site and its Oneonta Slough counterparts; however, the upperelevation vegetation has more salt grass (Distichlis spicata) and less shore grass (Monanthochloe littoralis), while the middleelevations are less diverse (only pickleweed and alkali heath are present).

\subsubsection{Soil Salinities}

Marsh soils were relatively stable in salinity between 1989 and 1991, three years that had below-average annual rainfall (Zedler et al. 1991). Despite the low annual totals, growing conditions were quite favorable in both 1990 and 1991. The rainfall distribution appears to be far more important than annual totals. In 1989, rainfall was low overall, and the wet season was essentially over by the end of March. In 1990, however, there was substantial rain in January through June. And in 1991, there were heavy rains in March. With long-term data on soil salinity and vegetation during years of low rainfall, it will be possible to evaluate the effects of rainfall distribution.

April soil salinities in 1990 and 1991 averaged lower than September salinities (Table 5.5). Evaporation during the long dry summer and transpiration during the growing season act together to elevate soil salinity to hypersaline conditions. In fall and winter, high spring tides may reduce hypersaline conditions somewhat, but rainfall probably has the more important leaching effect. By April, surface soils are usually near sea water in salinity. Surface soil salinities $(5$ $\mathrm{cm})$ were representative of those at greater depth $(25 \mathrm{~cm})$ during the monitoring period.
Table 5.5. Soil salinities for lower-, middle-, and upper-elevation transects, at 5 and $25 \mathrm{~cm}$ depth. April data are from 1990 91; September data are from 1989-91.

$\begin{array}{rllll}\text { Lower } & & & & \\ 5 & 31.4 & 24-37 & 36.7 & 28-43 \\ 25 & 32.4 & 26-36 & 37.8 & 34-41\end{array}$

Middle

$\begin{array}{ccccc}5 & 41.0 & 34-50 & 46.4 & 39.57 \\ 25 & 38.3 & 31.45 & 47.5 & 38.57\end{array}$

Upper

$\begin{array}{lllll}5 & 13.9 & 4-27 & 28.9 & 3-38 \\ 25 & 20.8 & 8-32 & 27.8 & 3-39\end{array}$

The March 1991 rainfall totalled 7 inches $(17.7 \mathrm{~cm})$ at Lindbergh Field, San Diego. This was 4.4 times the average March rainfall and $75 \%$ of the annual average. Soil salinities were lowered by the event; for 23 of the 24 comparisons (12 transects, 2 depths), the 1991 April salinity means were lower than those of 1990 .

\subsubsection{Salt Marsh Vegetation}

Most of the vascular plants remained similar in cover over the three-year period (Table 5.6). The data provide a summary of lower-, middle-, and upper-elevation species composition, which can be used to set objectives for restoration projects.

The cordgrass canopy showed small but significant changes over the 1989-91 sampling period. Densities increased overall, from $101 / \mathrm{m}^{2}$ in 1989 , to $112 / \mathrm{m}^{2}$ in 1990 and $145 / \mathrm{m}^{2}$ in 1991 . Total stem lengths followed the same pattern, since the two variables were almost perfectly correlated in this data set $\left(R^{2}=0.99, n=12\right)$. 
Table 5.6. Cover (\%) of 12 species encountered in the lower-, middle-, and upper-elevation transects. Data are means (4 transects $\times 3$ years) for 1989-91, taken in September.

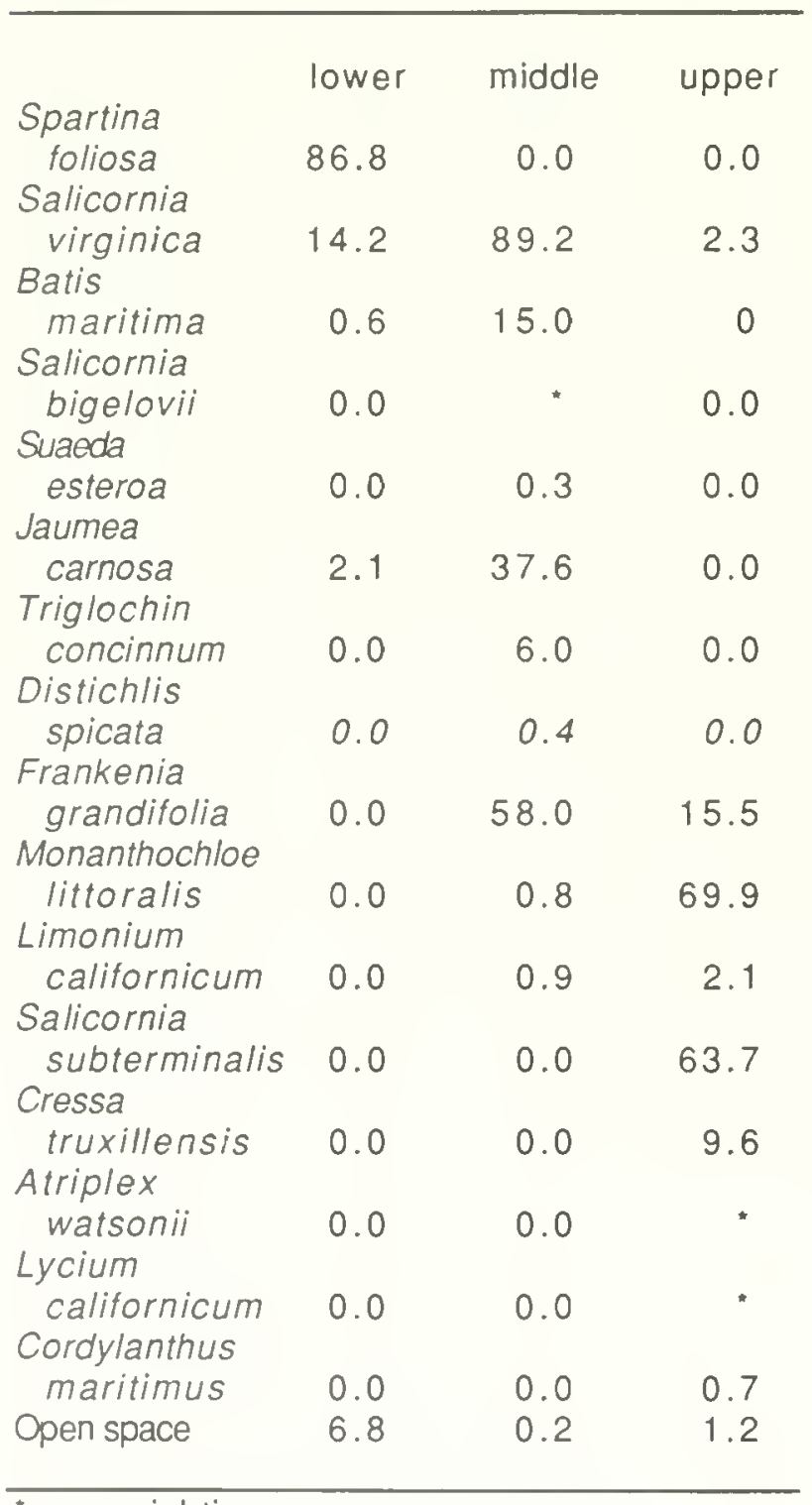

"=one sighting

For all three years, cordgrass height distributions (Figure 5.12) showed high proportions of stems in the 61-90 and 91$120 \mathrm{~cm}$ height classes. The increased densities in 1990 and 1991 show up as larger proportions of short stems for those two years (Figure 5.12).

\subsection{TIJUANA ESTUARY AS A REFERENCE SITE FOR "NATURALLY FUNCTIONING" SALT MARSH}

The existence of a salt marsh monitoring program has significance for two aspects of coastal management. First, as a site that currently supports endangered species, the data from Tijuana Estuary can be used to set goals for resource management and restoration planning. Second, the information can be used as reference data with which to evaluate the functional equivalency of restored or construcled marshes.

Because Tijuana Estuary has a growing population of clapper rails, it is reasonable to assume that the cordgrass habitat is adequate for rail nesting activities. A comparison of the Tijuana Estuary cordgrass marsh and other marshes that lack clapper rails indicates that cordgrass height distributions, rather than density, biomass, total stem length, or cover data, are a critical attribute of the habitat for nesting and cover (Zedler, in review). In contrast to the height distributions of Figure 5.12, constructed marshes have most of their stems in classes $1-2$ and few or no stems taller than $90 \mathrm{~cm}$. The problems for clapper rails are obvious when the highest lides occur--this type of cordgrass canopy is completely inundated, while that of the natural marsh protrudes above the water.

Other species of the cordgrass marsh may also require tall vegetation. The short plants at Chula Vista's Wildlife Reserve (a large dredge-spoil island) have suffered repeated attacks by scale insects (Haliaspis spartina). One natural predator of the scales is a beetle (Coleomegilla fuscilabris; Figure 3.11), which is not an aquatic insect. At high tide, the beetles of the natural marsh can escape inundation by crawling up the tall cordgrass stems (K. Williams, SDSU, pers. comm.). The failure of these beetles to become established on the island may in part be due to its isolated location. However, the failure of beefles to control scales following transplantation to the infested areas by $\mathrm{K}$. Williams is more likely an effect of inadequate cordgrass canopies. 

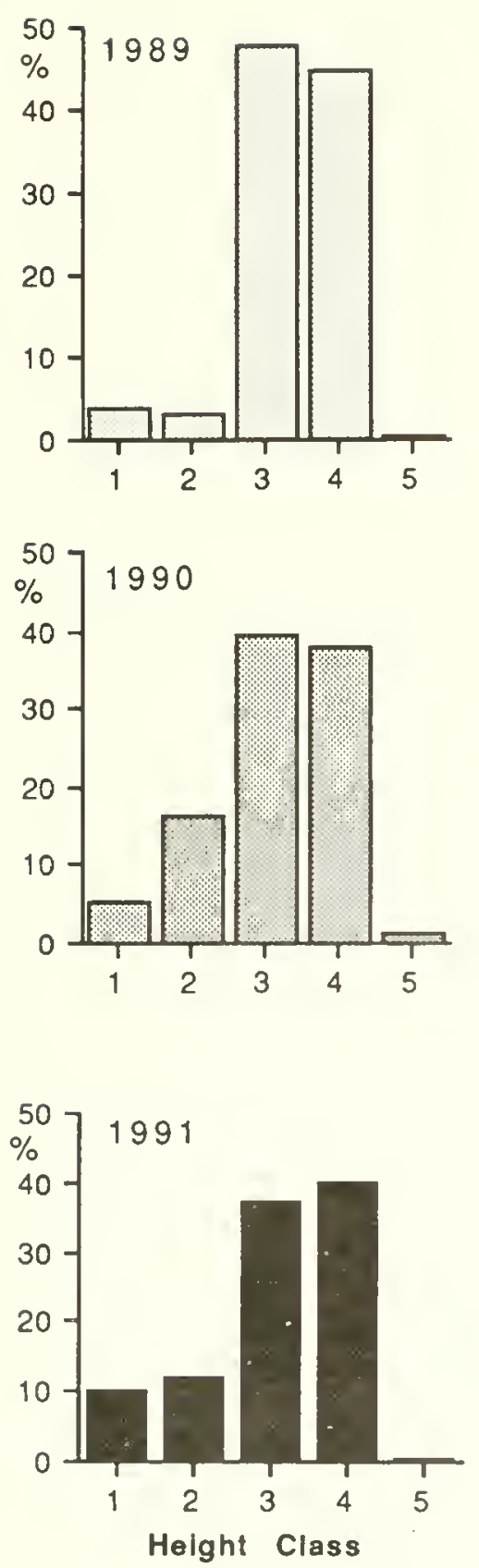

Figure 5.12. September height distributions for cordgrass over a three-year period. Stem heights were pooled for ten $0.1-\mathrm{m}^{2}$ quadrats $\times 4$ stations. Height classes are 30 $\mathrm{cm}$ intervals (approximately 1-ft), i.e., $1=$ $0-30 \mathrm{~cm}, 2=31-60 \mathrm{~cm}, 3=61-90,4=$ $91-120,5=120-150 \mathrm{~cm}$. The number of stems was 406 in 1989, 446 in 1990, and 579 in 1991.
Plants of the constructed marshes at both the Chula Vista Wildlife Reserve and the Sweetwater Marsh National Wildlife Reserve have reduced stature because soil nitrogen supplies are limiting (Langis et al. 1991, Zedler 1991b).

The importance of having many tall stems $(60-120 \mathrm{~cm})$ has led to the recommendation that cordgrass canopy architecture be a primary criterion in judging habitat suitability. Two San Diego Bay marshes that were designed and constructed for clapper rail nesting have not yet attracted the species. Their canopies differ from those at Tijuana Estuary in having fewer tall stems; densities, on the other hand, are often similar or higher. Thus, the data from Tijuana Estuary suggest that densities alone are not the critical factor, but rather the density of tall stems. These reference data suggest minimum standards for "suitable clapper rail habitat" in southern California (Zedler, in review).

Individual data sets have far less use in marsh-to-marsh comparisons than longterm records. The magnitude of year-to-year variations within a marsh must be known in order to determine if a man-made marsh is truly different from natural ones. The 1989 and 1990 data at Tijuana Estuary were critical to the comparison of constructed marshes sampled in 1989 and 1990 (Zedler, in review). Of further value is the fact that the Tijuana Estuary monitoring program provides information on a variety of factors that elucidate cause-effect relationships. Understanding the reasons for differences between natural and constructed marsh vegetation (e.g., nitrogen limitation) leads to corrective measures (e.g., soil amendments). Because there is a long-term monitoring program, the Tijuana River National Estuarine Research Reserve has unique value as a reference site.

\subsection{RESPONSES OF FISHES AND BENTHOS TO HYDROLOGIC DISTURBANCES}

Wastewater has flowed down the Tijuana River in large volumes from 1986 through 1991. A peak discharge in winter 1986 was 
followed by about 6 months of low flow. Flow volumes were on the order of 5 to $20 \mathrm{MGD}$ in late 1986 and early 1987 but increased again in late 1987. More recent years had flows of approximately 13 MGD (IBWC, unpubl. data). From comparisons of Tijuana Estuary and Los Peñasquitos Lagoon (Nordby and Zedler 1991), and from experiments with both fishes and molluscs (Nordby and Baczkowski, unpubl. data), it has become clear the the nonsaline character of the sewage flows has significant effects on the channel biota. The organic matter (through its biological oxygen demand) and contaminants are also important, but salinity dilution alone can stress or kill the native species of Tijuana Estuary.

\subsubsection{Sampling to Document Changes in the Channel Community}

The Tijuana Estuary channel monitoring program has three sampling stations in Oneonta Slough (Nordby and Zedler 1991); they reflect differences in channel morphometry (width, depth and substrate type) and distance from the mouth. The Mouth station received sewage continuously and directly from Tijuana River; the northern two sites were diluted by sewage when incoming lides forced river flows to spread laterally. The Mouth station is just inside the ocean inlet on a side channel paralleling the Tijuana River. This is the shallowest site $(<0.5 \mathrm{~m})$; it has sloping banks $6-7 \mathrm{~m}$ wide with a sand substrate. The E-W Channel station is about $1800 \mathrm{~m}$ from the mouth in a very old manmade channel that runs east 10 west and links the former sewage lagoons with Oneonta Slough. This is the deepest site (usually about $1 \mathrm{~m})$; it has eroding banks $10-11 \mathrm{~m}$ wide. The substrate is a clay/mud mixture with broken shell fragments in the upper 10-15 $\mathrm{cm}$ over a bed of coarse sand/gravel. The Sea Coast Channel station is about $900 \mathrm{~m}$ north of the mouth; it is $15 \mathrm{~m}$ wide and usually less than $1 \mathrm{~m}$ deep; it has a sand substrate.

Nordby and Zedler (1991) analyzed 12 quarterly samples of fishes (June 1986 March 1989), 10 quarterly samples of bivalves (Sept. 1986-Dec. 1989), and 7 quarterly samples of polychaete and other benthic species (June 1987-Dec. 1988) 10 identify impacts of sewage inflows.

\subsubsection{Response of the Fish Community}

Over the three-year period, 21 species of fishes representing 15 families were collected. The dominants were arrow goby (Clevelandia ios) $75 \%$, topsmelt (Atherinops affinis) $19 \%$, and California killifish (Fundulus parvipinnis) 3\% The remaining 19 taxa added $3 \%$ to the total fish caught (Nordby and Zedler 1991).

During the study, the fish community shifted from one co-dominated by topsmelt and arrow gobies to dominance by arrow gobies (Table 5.7). There were 14 species of fish in September 1986 and only 6 species in December 1988 and March 1989. The largest drop occurred between September 1986 and June 1987, when sewage inflows became more frequent and voluminous. The number of species declined with proximity to the mouth (two-way ANOVA without replication, $p<0.05$ ), with the Sea Coast Channel averaging 7 species; the E-W Channel, 6 species; and the Mouth, 5 species. Fishes also declined in size. Topsmelt averaged $188 \mathrm{~mm}, 121 \mathrm{~mm}$, and $68 \mathrm{~mm}$ for the three successive June sampling periods (one-way ANOVA, $p<0.001$; Nordby and Zedler 1991).

The community shift also represents a change in life history strategy loward shortlived species with prolonged reproductive periods. Whereas topsmelt are longer lived, the arrow goby matures within one year (Brothers 1975) and spawns from September through June.

Increased abundances of arrow gobies may have been influenced by reduced predation pressure from other fishes, e.g., California halibut (Paralichthys californicus) diamond turbot (Hypsopsetta guttulata), Pacific staghorn sculpin (Leptocottus armatus), and California killifish (Fundulus parvipinnis). The longjaw mudsucker (Gillichthys mirabilus), which may have been extirpated by the 1984 nontidal drought, is also an aggressive predator that may have had an 
Table 5.7. Relative abundance (\%) and total numbers of fish collected at Tijuana Estuary from 1986-1989 (from Nordby and Zedler 1991).

$' 86-' 87 \quad 87-' 88 \quad 88-' 89$

$\begin{array}{lccc}\begin{array}{c}\text { Atherinops } \\ \text { affinis }\end{array} & 52 & 14 & 7 \\ \begin{array}{c}\text { Clevelandia } \\ \text { ios }\end{array} & 41 & 58 & 90 \\ \begin{array}{c}\text { Fundulus } \\ \text { parvipinnis }\end{array} & 4 & 19 & 1 \\ \begin{array}{c}\text { Gillichthys } \\ \text { mirabilis }\end{array} & 0 & <1 & <1\end{array}$

Total number

$\begin{array}{llll}\text { caught } 20,888 & 4,976 & 54,301\end{array}$

important role in reducing goby populations prior to this sludy (Nordby and Zedler 1991).

\subsubsection{Benthic Invertebrate Responses}

Fifty-eight taxa of polychaetes and bivalves were collected from September 1986 to June 1988 (Nordby and Zedler 1991). The California ghost shrimp (Callianassa californiensis), a decapod crustacean, was also present. Through the sampling period, there was both a decline in the numbers of species and in densities. Bivalve densities were highest in Septembèr 1986 (with $\sim 2500 / \mathrm{m}^{2}$ collected at The E-W Channel).

Jackknife clams (Tagelus californianus) were initially dominant but declined in 1987 and again in 1988. Ghost shrimp were found in low densities in 1986 but increased thereafter. The false mya (Cryptomya californica) was absent in 1986 but became more common through time, along with its commensal, the ghost shrimp. Littleneck clams (Protothaca staminea) also increased in abundance through the study. Mean sizes of the two dominant species (jackknife clams, $40.3 \mathrm{~mm}$; littleneck clams, $11.2 \mathrm{~mm}$ ) suggested that most were 0-1 year old. Thus, Nordby and Zedler (1991) concluded that the benthic community was largely newly recruited individuals.

Highest bivalve densities were generally at the E-W Channel, which is farthest from the river of sewage. One other disturbance, dune washover, complicaled the picture. Station TJE1 was buried with several $\mathrm{cm}$ of coarse sand twice during the study and dredged once to remove sediments. Turbid water and/or mechanical removal were no doubt detrimental to the bivalves.

Capitellids and spionids were the dominant polychaetes (Table 5.8). Greater numbers of polychaetes were collected in 1988 than in 1987, especially at the Mouth station. Capitellids and spionids, primarily Polydora nuchalis and $P$. cornuta were the most abundant in 1988; both are known to tolerate pollution. Polychaete densities were low until Seplember 1988, when densities exceeded $4,000 / \mathrm{m}^{2}$ (Nordby and Zedler 1991). The dominant polychaete species are ones that mature quickly; some capitellids become reproductive within a month and may reproduce year-round (Grassle and Grassle 1976).

\subsubsection{Cause-Effect Relationships}

Nordby and Zedler (1991) concluded that salinity dilution was the primary cause of species eliminations, density reductions, the predominance of young animals, and dominance by species with early reproductive maturity and prolonged spawning periods. Three reasons were given:

First, historical streamflow data showed that summer flows were rare or absent and that large, old bivalves were abundant. Prior to the 1978 flood, Hosmer (1977) measured the sizes of the dominant bivalves and found means of: $71 \mathrm{~mm}$ for Nuttallia nuttallii; 22 $\mathrm{mm}$ for littleneck clams and $27 \mathrm{~mm}$ for jackknife clams. Of these species, Nuttallia 
Table 5.8. Relative abundance (\%) and lotal numbers of invertebrates collected at Tijuana Estuary between 1986 and 1989 (from Nordby and Zedler 1991). $X=$ no data.

$86-87 \quad 87-88 \quad 88-89$

\begin{tabular}{|c|c|c|c|}
\hline \\
\hline \multicolumn{4}{|l|}{$\frac{\text { Blvaives }}{\text { Tagelus }}$} \\
\hline californianus & 73 & 33 & 27 \\
\hline \multicolumn{4}{|l|}{ Protothaca } \\
\hline staminea & 19 & 34 & 42 \\
\hline \multicolumn{4}{|l|}{ Macoma } \\
\hline nasuta & 2 & 17 & 19 \\
\hline \multicolumn{4}{|l|}{ Cryptomya } \\
\hline californica & 0 & 6 & 4 \\
\hline Total collected & 658 & 490 & 651 \\
\hline \multicolumn{4}{|l|}{ Polychaetes } \\
\hline $\begin{array}{l}\text { Capitellidae } \\
\text { Spionidae }\end{array}$ & $x$ & 33 & 50 \\
\hline Bocardia spp. & $x$ & $<1$ & 5 \\
\hline Polydora spp. & $x$ & 18 & 20 \\
\hline $\begin{array}{l}\text { Nephtys spp. } \\
\text { Spiophanes }\end{array}$ & $x$ & 16 & 1 \\
\hline missionensis & $x$ & 0 & 8 \\
\hline Opheliidae & & & \\
\hline Armandia brevis & $x$ & $<1$ & 5 \\
\hline Unidentified taxa & $x$ & 3 & 0 \\
\hline Total collected & & 276 & 1,422 \\
\hline
\end{tabular}

nuttallii no longer occurs at Tijuana Esluary and the littleneck clams are half as large.

Second, the station that is farthest from the river ( $E-W$ Channel) sustained the most species and higher densities. The E-W Channel acted as a refuge for Tagelus californianus, Protothaca staminea, and Macoma nasuta. The latter two species had a strong preference for this site.

Third, the dominant polychaetes were species that are tolerant of wastewater. In Los Angeles Harbor, Crippen and Reisch (1969) found that Capitella spp. and Polydora cornuta were most abundant in polluted to very polluted areas.

Furthermore, a comparative study at Los Pefiasquitos Lagoon, showed that freshwater inflows led to fish kills in 1987 and again in 1988. Both floods occurred when that lagoon was closed to tidal flushing; hence the fresh water accumulated and had a major, negative impact on the channel biota (Nordby and Zedler 1991). While the fish kills at Los Peñasquitos Lagoon were more obvious than the sewage impacts at Tijuana Estuary, the fact that both freshwater disturbances reduced species diversity and abundances lends credence to the argument that freshwater inflows are stressful.

Recent experimental work with several species of fishes and bivalves (Nordby, Baczkowski, and Zedler, unpubl. data) further demonstrated the effect of salinity dilution. In outdoor mesocosms, bivalve mortality increased with salinity dilution (comparing water of 34,17 , and 8 ppt). Fishes survived reduced salinity more readily than bivalves. Although California halibut had fairly high survival in brackish water, Baczkowski (M.S. thesis, in prep.) found reduced growth rates in diluted sea water, with greater effects among the smallest halibut.

\subsubsection{Summary (from Nordby and Zedler 1991)}

In response to sewage inflows, the fish community has become dominated by species that mature rapidly and have an extended spawning season. The bivalve population structure shifted to mostly young individuals. The polychaete fauna became dominated by species that are associated with pollution; they mature early and have prolonged spawning seasons. The cause-effect relationship is supported by spatial comparisons within the estuary. The sampling station farthest from the sewage inflows sustained the highest densities of bivalves, while the sampling station in the path of the river supported the fewest species of fish. 


\section{CHAPTER 6}

\section{ADAPTIVE MANAGEMENT AND RESTORATION}

Tijuana River National Estuarine Research Reserve is managed for resource protection, research, interpretation, land acquisition, and facilities development. The Research Reserve includes the Tijuana Slough National Wildlife Refuge, which is managed by the U.S. Fish and Wildlife Service, and Border Field State Park, which is managed by the California Department of Parks and Recreation. The specific goal of the Refuge is to protect three endangered species, the light-footed clapper rail, the California least tern, and salt marsh bird's beak.

A program of adaptive management (Walters and Hilborn 1978), with long-term monitoring, field studies, manipulative experiments, and a major restoration program, guides resource management at Tijuana Estuary. The first management plan for the Research Reserve was developed by Michelle Lamay (Dobbin Associates 1986). A multiple-agency Management Authority directs the management and restoration activities and holds monthly meetings at the Visitor Center. Additional plans were developed as part of the tidal restoration program and impact assessment (Entrix el al. 1991).

\subsection{RESEARCHNEEDS AND OPPORTUNITIES}

In order to accomplish the main purposes of the reserve and the refuge, the native biota of Tijuana Estuary must be maintained. Research activities have led to many management recommendations, many of which have been implemented at Tijuana Estuary and other coastal wetlands in California. Thus, this estuary contributes to the maintenance of biodiversity throughout the region.

Since the 1970's, there has been a continuing research interest in Tijuana Estuary, with emphasis on the salt marsh vegetation. The research projects have anticipated and/or followed environmental changes and ecosystem responses. Studies have progressed from descriptions of species occurrences and measurements of welland processes to long-term comparisons of the effects of disturbances. There has been a growing emphasis on the experimental determination of cause-effect relationships.

Tijuana Estuary is a rich laboratory for science. The vegetation-monitoring program that began in 1979 documented several distinct disturbance events. However, many effects were unquantified (e.g., changes to benthic invertebrates and fishes). Monitoring was extended to include channel waters and regular sampling of benthic invertebrates and fishes in 1986. Bird monitoring still needs to be added. Long-term systematic sampling focused to identify cause-effect relationships is an appropriate approach for an estuary that is subject to a highly variable environment. The long-term data track in turn provides an excellent backdrop for specific studies of population, community, and ecosystem dynamics.

\subsection{RESEARCH FACILITIES}

The Pacific Estuarine Research Laboratory (PERL) provides experimental facilities for 
estuarine science. This facility was originally located on 70 acres of abandoned agricultural land at the southern edge of Tijuana Estuary (Figure 6.1). It was moved near the Visitor Center in 1990 to gain greater security and improve facilities. Its main purpose is to support experimentation in outdoor mesocosms (moderate-size artificial wetlands in replicate). The disturbances to Tijuana Estuary are what catalyzed a shift toward manipulative experimentation. Controlled field experiments became impossible when background conditions (e.g., tidal flushing) could not be assured. The NOAA Sanctuary Programs Division and California State Resources Agency sponsored the development of the outdoor laboratory, which is operated by San Diego State University.

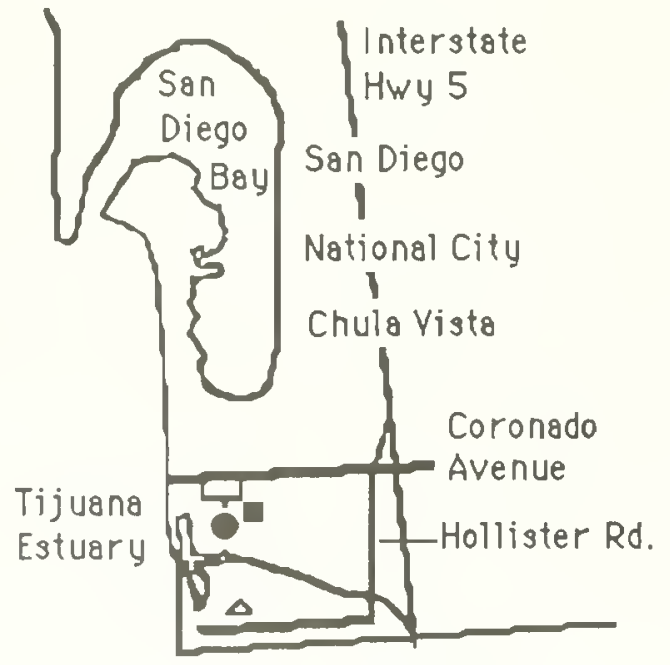

Tijuana

Visitor Center

PERL mesocosm facility

- Original PERL site

1800 Monument Rood

Figure 6.1. Location of the Visitor Center for Tijuana River National Estuarine Research Reserve at 301 Caspian Way (accessible from 3 rd or 4 th Streets, which intersect Coronado Ave./Imperial Beach Blvd.). Symbols mark two research facilities developed by PERL.
The types of mesocosms that were built and used for thesis research by SDSU graduate students included coastal scrub vegetation ( $A$. Corbet, SDSU, unpubl.), fish ponds (White 1986), dunes (Wood 1987, Vourlitis 1991), lower- and middle-elevation salt marshes (Griswold 1988), and lagoon waters populated by phytoplankton, macroalgae, and epibenthic algal mats (Fong 1991).

\subsubsection{Habitat Construction}

In addition to providing mesocosm facilities for research, the PERL site was used to construct large wetland habitats and to establish native plant nurseries for local restoration projects. The State Resources Agency (Environmental License Plate Fund) and the State Coastal Conservancy sponsored the habitat construction project in the late 1980's. Fresh, brackish, and saline impoundments of several sizes were constructed by Chris Nordby and Barry Dubinski to determine whether such habitats would subsidize areas used by estuarine species. The wetlands extended over about 30 acres of the original PERL site and provided essential refuges during times of wholeecosystem perturbation. They attracted wildlife and helped to determine how salinity and vegetation influence animal use.

\subsubsection{Native Plant Nurseries}

A native plant nursery was developed and used to propagate coastal plants for transplantation to regional restoration projects. At the request of the California Department of Parks and Recreation, native dune plants were grown by Brian Fink for dune restoration projects at Border Field State Park and Silver Strand State Beach. These restoration projects were a direct outgrowth of Fink's earlier M.S. thesis research (Fink 1987).

The PERL nursery was also used by Brian Fink to propagate native halophytes for the salt marsh restoration at San Diego Bay (Sweetwater Marsh National Wildlife Refuge). 
Most of the plants were taken from areas that were disturbed by construction projects at San Diego Bay, then moved to the PERL nursery, planted in trenches that were kept saline and wet, and allowed to expand until new marsh habitats were constructed as mitigation for the earlier damages at San Diego Bay. In spring 1991, a 7-ha (17-ac) excavated marsh at San Diego Bay was transplanted entirely from plants propagated at the original PERL site in a project supervised by the California Department of Transportation. Lower-, middle-, and upper-elevation marsh species were all included in the habitat-creation project. The nursery has been phased out, but the information gained on how to culture native dune and welland species now guides restoration programs throughout the region.

\subsubsection{Wastewater Welland Mesocosms}

Complementary funding from the California Sea Grant College and NOAA's Sanctuaries and Reserves Division made possible an innovative wastewater wetland study, which required replicate mesocosms planted with the native bulrush (Scirpus californicus). Twenty mesocosms, each 2.1 $\mathrm{m}^{2}$, were installed at the new PERL site in December 1989 by Chris Nordby. Each was plumbed with a freshwater inflow from a common tank for mixing simulated sewage, connected to an outflow with a solenoid valve to control the discharge regime, and hooked to a sewer line. Research was conducted by two graduate students (Busnardo 1992 and Sinicrope 1992) and supervised by $R$. Gersberg, R. Langis and J. Zedler.

These mesocosms were used to answer two questions about wetlands as wastewater treatment facilities--could manipulating the water levels of a welland improve nutrient (nitrogen and/or phosphorus) removal efficiency, and would heavy melal removal differ if water levels rose and fell, rather than remaining constant, as in most wastewater wetlands? The results (Busnardo 1992; Sinicrope 1992) indicate that a twice-daily discharge regime provides maximum removal of both nutrients and heavy metals. These findings have broad implications for wastewater management throughout the region.

Since wastewalers in southern California derive primarily from imported water, their discharge to coastal water bodies artificially adds nutrients (and possibly contaminants), lowers their salinity and alters habitat value for marine and salt marsh species (cf. Chapter 5). Construction of wastewater wetlands upstream of the estuary would improve the quality of the discharge. Use of a twice-daily pulsed-discharge regime would not only improve the water treatment capability of the wetland, it would also reduce the problem of salinity dilution downstream. By timing the discharge to coincide with the twice-daily ebb lides, inflowing fresh water would move quickly through the ocean inlet and damage less of the channel and marsh habitat.

\subsubsection{Tidal Mesocosms}

The newest mesocosm facilities are being constructed for studies of hydrologic effects on pickleweed (Salicornia virginica) marshes. This plant is the most widespread species of southern California's salt marshes. It occupies sites that are fully tidal, as well as habitat remnants that have not been tidal for many decades. To understand how tidal flushing and freshwater inflows affect this species--and our ability to restore pickleweed habitats at Tijuana Estuary and other coastal wetlands--a manipulative experiment has been planned by J. Zedler, S. Williams and J. Boland. Both the degree of tidal flushing and the presence of freshwater inflows will be controlled and the response of the pickleweed canopy and epibenthic algal mats determined.

Construction of 24 tidal mesocosms began in 1990, under the supervision of Bruce Nyden, with volunteer Mac McEachern operating the back hoe. All 24 were provided with freshwater irrigation lines to stimulate growth of pickleweed seeds and transplants. Tide gates will control the degree of tidal 
flushing, with three treatments planned for initial experimentation: full tidal flushing, tide waters excluded to maintain relatively dry saline soils, and tide waters impounded to create waterlogged soils. Initially, there will be 8 replicates for each of the three tidal flow regimes. After a year of study, freshwater inflows will be added to half the mesocosms in each tidal treatment for a fully-crossed twofactor experiment.

Funding has been requested from the U.S. Fish and Wildlife Service and from NOAA'S Sanctuaries and Reserves Division. Results are expected to guide pickleweed marsh restoration projects at Tijuana Estuary and other restoration programs in southern California.

\subsection{MANAGEMENT NEEDS}

Tijuana Estuary is an urban estuary subject to the chronic and acute impacts of an enormous human population. The City of Imperial Beach surrounds the northern arm of the estuary. Agricultural lands and a large system of levees for flood control have modified the Tijuana River floodplain. Just upstream, the city of Tijuana, Mexico, includes over 2 million inhabitants, most of whom do not even have access to a sewer system. The watershed above Tijuana is scheduled for rapid and extensive development. At the same time, the downstream estuary is supposed to serve as a reserve for research and education, a refuge for endangered species, and a state park.

Management problems are numerous, but four stand out as having the greatest impact on estuarine ecology: sedimentation of channels, erosion of the beach and dunes, inputs of sewage, and modification of streamflow. Each problem has multiple causes. Increased sedimentation follows disturbance of soilstabilizing vegetation both within the watershed and on the beach. The beach and dunes erode when storms and high sea levels coincide. Sewage spills are almost entirely traceable to breaks in Mexican sewage lines, although local leaks are not unknown. Streamflow augmentation is associated with reservoir and wastewater discharges; their effect is greatest during summer, when the river might otherwise be dry.

These many disturbances are interrelated: dune sands contribute sediment to channels, and sewage spills alter streamflows. The causes of these problems must often be dealt with separately; for example, dunes can be stabilized with fencing or vegetation to resist storm damage, but nothing can control sea levels. Mitigation of impacts, on the other hand, requires a comprehensive approach, because altering habitat in one area can potentially affect the entire ecosystem. For an estuary that is managed primarily for its native wetland communities and endangered species, passive management (leaving nature alone) might seem preferable to active manipulation of environmental conditions. But disturbances have had significant impacts on the estuary, and the issue is not whether, but how much, intervention is required to maintain native species.

\subsubsection{Sedimentation Problems}

Throughout southern California, estuaries and lagoons have been filling in rapidly, as hillsides within their watersheds are disturbed and developed. Vegetation that might slow erosion is sparse in Mexico, where grazing is more common and fires more frequent in the landscape (Minnich 1983). The extremely erodible soils move downstream with winter rains, and catastrophic sedimentation occurs at the coast. Mugu Lagoon lost $40 \%$ of its low-lide volume with cumulative sedimentation during the floods of 1978 and 1980 (Onuf 1987). Sedimentation is a natural process, but the rates have accelerated, and the system's ability to respond by changing its configuration has been constrained by peripheral developments.

Other natural events that counter the impacts of sedimentation may also be augmented by human activities. For example, the greenhouse effect may be accelerating sealevel rise and somewhat compensating for sediment accretion. However, the average 
rise in sea level cannot begin to keep up with catastrophic sedimentation, and the net effect is for coastal wetlands to fill in more rapidly that they would naturally.

\subsubsection{Beach and Dune Erosion Problems}

Winter storms that coincide with high sea levels erode the dunes and beach. Summer is the rebuilding phase in an annual cycle of removal and replenishment. However, if the replenishing sands are intercepted in their transport along shore or downstream, the beach and dunes show a net loss (Inman 1985). In addition to the annual cycle, there is a long-term trend for an increase in mean sea level, which gradually moves the beach inland.

Disturbance of beach vegetation has contributed to the destabilization of the dunes, and replanting efforts have been underway in recent years ( $P$. Jorgensen and $B$. Fink, Dept. of Parks and Recreation project, unpubl.). Further dune stabilization, through extensive revegetation efforts, is called for in the restoration plan.

\subsubsection{Streamflow Modifications}

Reservoirs modify estuarine hydrology by reducing total volume of streamflow, by delaying the start of floodflows, or by prolonging the period of wet-season flows. In the United States portion of the Tijuana River watershed, Barrett and Morena Reservoirs trap streamflow and presumably modify the timing and volume of floodflows. Water can be discharged from Morena to Barrett, but the gates of Barrett Reservoir cannot be opened once water is impounded; thus, drawdown is not possible. In Mexico, Rodriguez Reservoir has gates that can be used to lower water levels, and the prolonged discharges of 1983 indicate the magnitude of streamflow change that can occur as a result of reservoir drawdown. Record flows for 10 months (March through December) occurred during periods of little rainfall and low streamflows (Table 6.1). At such times, salinities are
Table 6.1. Streamflow data (acre-ft) for the Tijuana River at the United States-Mexico border. All 1983 flows were augmented by discharges from Rodriguez Dam; flows for March-December 1983 were maximum for the period of record (from IBWC 1983).

Month 1983 Flow Mean Flow

January

February

March

April

May

June

July

August

September

October

November

December
5,236

35,849

293,494

62,938

42,599

9,696

9,242

17,092

978

1,237

4,377

6,705
2,824

10,141

13,875

3,584

1.979

519

366

541

74

87

250

501 lowered (Chapter 5), tidal regimes are probably muted, and nutrient concentrations increase (Covin 1984).

Streamflow into Tijuana Estuary has been altered by wastewater discharges from Tijuana, Mexico, since the land slopes northward towards the United States. The largest influxes occurred as sewage discharges that were continuous from the mid-1980s until early October of 1991. Sewage spills still occur when there is a break in the Mexican pipelines, which are designed to carry sewage west and south to an intertidal outfall. Flows exceeding $7,000 \mathrm{~m}^{3}$ per day (over 2 MGD) have occurred at various unpredictable intervals.

A major sewage interception system is now under construction, wherein flows from four canyons will be collected and piped to the San Diego treatment plant (City of San Diego Clean Water Program). A new sewage treatment plant will be built at the U.S.Mexico Border, with plans for it to begin 
operation in 1995 (IBWC Staff, pers. comm.).

For the estuary, the ecological impacts of wastewater influx are multiple: reduced salinities, increased nutrient loadings, and contamination with toxic materials. Unlike most regions of the United States, where wastewater influxes are of concern primarily because estuaries undergo eutrophication, a greater problem in the arid southwest is altered hydrology. River flow is normally low and confined to winter; wastewater discharges would change an intermittently flowing stream into a permanently flowing river. An evaluation of how increased streamflow affects the estuary (Zedler et al. 1984a,b) identified impacts on fishes, invertebrates, vascular plants, and algae and led to recommendations on how to reduce negative impacts (Zedler et al. 1984c).

A model of estuarine salinity was developed to predict dilution with discharges of 12.5, 100, and 200 MGD (Figure 6.2). The 41 -year record includes 10 years of "heavy" flow (greater than 10,000 acre$f t / y r), 13$ years of intermediate flow (100. 10,000 acre-ft/yr), and 18 years of low flow (0-100 acre-ft/yr). Monthly averages were computed for intermediate-flow years. Wastewater discharges of 30-35 MGD would exceed these intermediate-year flows six-fold in winter and much more in summer. Water salinity in Tijuana Estuary would be reduced enough to affect marine species substantially (Zedler et al. 1984b). Measurable dilution would occur with only 12.5 MGD. During neap tides, salinities would drop much more than during spring tides. It was predicted that the estuary would become slightly brackish at 12.5 MGD and fresh at $200 \mathrm{MGD}$.

Even slightly brackish conditions affect the channel biota (Chapter 5). New research (Nordby and Baczkowski, unpubl.; Baczkowski, in prep.) shows that even brief exposure to salinities of $17 \mathrm{ppt}$ can kill molluscs and impair growth of young California halibut.

A second ecological impact of wastewater discharge is nutrient influx. Effects of nitrogen additions to lower marsh vegetation were examined by Covin (1984; 1986; Covin and Zedler 1988). Nitrogen is clearly limiting and plant growth increases with fertilization, but enrichment can also stimulate insect herbivory and reverse the stimulating effect on plant biomass. Experiments to determine the effect of wastewater and selected nutrients (nitrogen and phosphorus) on macroalgae, phytoplankton, and epibenthic algae were conducted by Rudnicki (1986) and Fong (1986, 1991; cf. Chapter 4). Nutrient addition stimulates all algal groups, but the group that responds most strongly depends on the ratio of nitrogen:phosphorus added (Fong 1991).

In the overall environmental assessment of wastewater discharge, the impacts of increased freshwater flow are outweighed by concerns for water quality. The Regional Water Quality Control Board ranks disease risks and potential for eutrophication (potential nuisance algal blooms and fish kills) more highly.

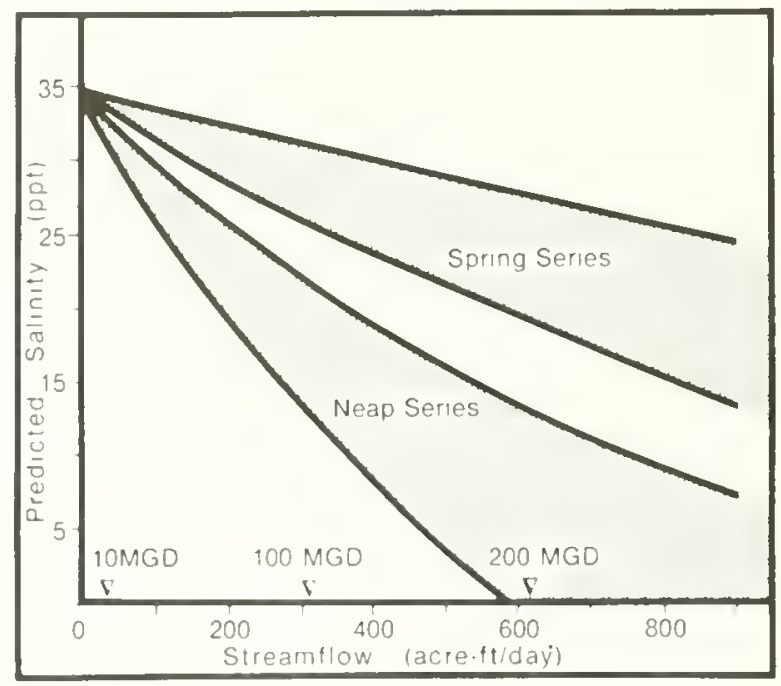

Figure 6.2. Simulated salinity reductions calculated iteratively, by alternating constant high and low tide levels until the salinity at low tide remained constant. Lines represent the highest and lowest values predicted during a 24-hr period with both spring and neap tide series (reprinted from Zedler et al. 1984b). 
Wastewater inflows are now being managed. Collection and diversion of sewage flows will correct most of the problems associated with dry-season inflows. Tidal restoration should improve the situation further, if increased tidal flows and stronger currents can remove at least some of the materials that have accumulated in the river channel over the past decade.

\subsubsection{Habitat Management}

Decades of disturbance to the estuary and its watershed have substantially altered the environmental factors that control habitats. The physiographic and hydrologic conditions that led to the pre-1900 ecological communities have been irreversibly changed. Since 1900, some communities have been lost entirely (e.g., woody beach vegetation), and other new ones have developed (e.g., brackish ponds and marshes). With the recently accelerated sedimentation rates and the threat of greatly altered streamflows, it is no longer possible to recommend passive habitat management of Tijuana Estuary. Careful, well-planned management procedures are required to insure that the recognized values of Tijuana Estuary are maintained.

Several management recommendations follow from the habitat values identified in Chapter 3. The overall management goal should be to maintain the natural variety of habitats (Zedler 1984), recognizing that increasing the area of any one habitat type should not reduce habitat for another. Singlespecies management is not desirable, because procedures that might benefit one species might negatively affect another. We list here the recognized values of each habitat type, identify management problems, and suggest management objectives.

- Transition from upland to wetland. This is a diminishing habitat in southern California; it is valued for its rarity, its function as a buffer between wetlands and urbanized areas, and as a foraging ground for bird species. Habitats that are transitional between wetland and upland now will be the wetlands of the future, as sea level continues to rise. Hence, a broad transition zone is needed to insure persistence of this fringing community and the high marsh below it. Species of concern include sensitive birds (e.g., short-eared owls, black-shouldered kites) and the horned lizard. The latter have been collected for pets and reduced to extremely low numbers. Frankenia palmeri is a potential member of the habitat, but it has not been recorded at Tijuana Estuary.

The generic problem facing the transition habitat is urban encroachment, which occurs as fill, trash disposal, trampling, and invasion by dogs and cats. Associated impacts are invasions by exotic weeds and altered densities of native animals.

Recommended management objectives are to remove fill, control visitor access, revegetate unofficial trails, control dumping of trash, control feral and domestic animals, control exotic plants, and plant native perennials that are likely to have occurred in this habitat. Suitable plants to consider include lemonadeberry, laurel sumac, boxthorn, and native succulents. Ideal locations for transition restoration projects are the slope at the corner of Imperial Beach Boulevard and Third Street, the abandoned gravel mounds near the gravel pit ponds, and abandoned agricultural lands along the periphery of the 495-acre restoration project.

- Salt marsh. The most widely valued attribute of the salt marsh is the habitat it provides for rare and endangered species. The cordgrass-dominated marsh is nesting and foraging habitat for the light-footed clapper rails; the pickleweed-dominated areas are important to Belding's Savannah sparrows; and the upper marsh is the sole habitat for salt marsh bird's beak. In addition, the marsh is essential to a variety of other organisms, including nonendangered birds, insects and invertebrates, as a place to feed, seek cover, and reproduce. Overall, the salt marsh vascular plants and algal mats contribute substantially to the primary productivity base that supports estuarine food chains.

We know that nontidal conditions can reduce the natural diversity of plant 
communities, and that some species do not recover from such disturbance (e.g., annual pickleweed). Some areas of disturbed upland should be excavated to expand the salt marsh habitats and new techniques found for creating fully functional ecosystems.

Tijuana Estuary provides many opportunities for restoration research that can build on work done elsewhere in the region. Experiments to improve cordgrass transplantation using soil amendments are in progress at San Diego Bay (Langis et al. 1991; J. Zedler, R. Langis, and K. Gibson, SDSU, in progress). Work is also underway to determine how best to reestablish salt marsh bird's beak to Sweetwater Marsh (B. Fink and J. Zedler, in progress). Pollinators appear to be a limiting factor, and research is needed to identify which bees are pollinators, where they live, and what size patches of bird's beak are needed to attract them. Very little work has been done on the salt marsh fauna and methods of transplanting animals have not been developed. Genetic research is needed to determine protocols for maintaining genetic diversity in transplanted species. Efforts to establish middle- and upper-marsh communities have only begun; the requirements of individual species and their interrelationships remain to be determined. Finally, the salt marsh monitoring program that began in 1979 needs to be funded on a permanent basis.

The potential conflict between resource management and visitor access needs to be confronted, with clear priorities developed. Access to salt marsh habitats needs to be carefully controlled to protect resources, but visitors may not be satisfied with views from a dislance. Data on responses of birds to disturbance (e.g., White 1986) need to be incorporated into planning for trails. Plans to construct a bridge across the East-West Channel, which would open remote areas of salt marsh and endangered species habilat to foot and vehicle traffic (Dobbin Associates 1986) should be revised. The channel became wider and the banks less slable, after dike breaching improved water circulation in the tidal ponds upstream. More important, the ecological communities and endangered species that would be affected by increased human use have not yet recovered from past trampling.

- Salt pannes. The natural values of salt pannes are not often recognized, and proposals are often made to convert them to other uses. During both the wet and dry phases, salt pannes are imporiant areas for insects, including rove beetles and mudflat tiger beetles. When inundated, the areas serve as feeding grounds for migrant and resident birds. Species associated with the intertidal salt marsh and the Iransition 10 upland also use these areas.

Lack of quantitative information about their habitat value limits our ability to manage and restore them. Another continuing problem in salt pannes is the compaction of soils caused by vehicle and foot traffic. Research is needed 10 quantify the communities of organisms that use salt pannes throughout the annual wet/dry cycle, building on the preliminary work of Nordby (1984).

- Brackish marsh. Areas that have reduced salinities throughout most of the year are currently maintained by rainfall and urban runoff. Although artificial in this sense, they do support an ecosystem with species native to the area. Elsewhere in the region, brackish marshes are valued for their augmentation of habitat for populations of clapper rails, black-necked stilts, snowy egrets, and other birds. They also increase habitat diversity at the estuary and attract species that would not otherwise occur there (e.g., red-winged blackbirds).

The management problem associated with brackish marsh is their potential expansion at the expense of saline wetlands. Freshwater runoff leaches soils of salts, and the brackish marsh species expand and displace those of the salt marsh. Where exotic weeds (such as brass buttons) and horticultural escapes establish, the expansion of brackish conditions detracts from the basic habitat management goal of maintaining natural habitats.

Curtailing the daily flows of sewage into Tijuana Estuary was a major improvement in brackish marsh control. Next, lidal 
restoration will improve the circulation of salt water and further reduce chances for brackish marsh expansion.

Brackish and freshwater marsh habitats can be expanded upstream of the estuary. Suitable sites exist along the Tijuana River and in abandoned agricultural lands. The use of treated wastewater is encouraged for creation and maintenance of artificial marshes.

- Channels and creeks. The channel habitats at Tijuana Estuary are important to nearly all estuarine animals; they are recognized for their value in support of the food chain. All of the endangered birds use channel and creek areas for feeding. In previous years, there have been recreational shellfisheries and commercial bait fisheries. At present, both shellfish gathering and fishing are prohibited in the estuary.

The problems that affect the channels and creeks ultimately have an impact on the entire estuary, because the estuarine waters move throughout the system. Tidal closure, sedimentation, disturbance from dredging, and reduced water quality (wastewater input, nuisance algal blooms, reduced salinity) all require active management. The impacts of tidal closure are detailed in Chapter 5 . Increased sedimentation rates have an impact on benthic organisms, and the associated lurbidity affects water-column species. Dredging to remove accumulated sediments and restore tidal flushing in turn creates turbidity and alters the substrate.

Tidal restoration should make existing channels more suitable, for fish and invertebrate use. Excavation of the experimental marsh should have beneficial effects downstream as increased flows erode the fine materials that have accumulated in the Old River Channel. New channels that will be constructed throughout the new tidal marshes should expand this habitat type substantially.

The monitoring program for channel fishes and invertebrates began in 1986, but was reduced in 1992 due to a $33 \%$ cut in funding. Sampling occurred quarterly through 1991, but will be done semiannually in 1992-94. Less frequent sampling will make it difficult to determine how the channel biota respond to the elimination of sewage flows and to improved tidal flushing once the restoration program is underway.

- Sandflats and mudflats. The intertidal flats are closely associated with tidal channels and creeks, and the impacts of disturbance and considerations for management are similar. The primary values attributed to these sites are their habitat for shorebird resting and foraging and feeding areas for the light-footed clapper rail and Belding's Savannah sparrow. Artificial impoundments can augment these natural shorebird habitats, as was demonstrated by the $70+$ wetlands constructed near PERL and used by numerous species of waterfowl and shorebirds. There are numerous opportunities to construct wetlands within the Tijuana River Valley, and treated wastewater should be used for habitat expansion inland of the estuary. Careful management of the hydrology of wastewater wetlands would be needed to insure that the downstream wetlands are not damaged by excessive discharges of fresh water.

- Beach and dunes. The esthetic quality of beaches makes them the habital most highly valued by the public. Consequently, human use is extensive throughout the year. Ecologically, the habitats are valued for their support of native animals, including the globose dune beetle, sandy beach tiger beetle, sand dune tiger beetle, wandering skipper, and two nesting birds, the California least tern and snowy plover. Other species, such as Belding's Savannah sparrow, feed on dune and beach insecis. The native plants are especially important to the ecosystem, because they stabilize the dunes, which in turn protect the estuary from sea storms.

The major problem facing the beach and dunes is coastal erosion. Substantial losses of sand occur each winter, but not all is replenished each summer; a continual net loss is obvious from aerial photos from 1928 through 1985. The height and location of dunes has changed with recent storm overwashes, and stabilization is needed. In 
addition, exotics (sea rocket and ice plant, Carpobrotus edulis) have invaded.

Fencing has helped to protect the dunes from trampling, but not all areas are fenced or maintained. It is widely agreed that additional dune stabilization is needed. Attempts to rebuild the dunes with dredge spoils began north of the mouth in 1985. Although the reconstructed dune helped protect estuarine channels from overwash during the 1986 storms, there was substantial erosion on the seaward side and dune crest, and most of the transplanted dune species died. Dune reconstruction south of the mouth was attempted, but storms ravaged the site before vegetation could stabilize the sand. The activities currently underway include fencing to reduce trampling and stabilize the sand, thereby facilitating revegetation efforts. Success will depend on how well the plant cover develops before another major storm occurs.

- River channels. There are no descriptions of the Tijuana River where it meets the estuary. A riparian ecosystem developed after the 1980 flood, and dense vegetation is now present within the reserve. Species composition and use by wildlife remain unquantified. Many of the future hydrologic changes that will occur at Tijuana Estuary may have their greatest impact on this habitat type. As sewage spills come under control, streamflows will decline. Research is badly needed to characterize the riparian species and their habital requirements. Determining the best management practices for this international river remains a major challenge.

The individual disturbances to each of the above habitats may seem minor. Collectively, however, they have shifted many features of the estuary and led to the decline of several native species. It would have been difficult to predict that trampling and denuding the dunes would be a major cause of the population crash of clapper rails in 1984. The cumulative impacts of denudation, sedimentation, mouth closure, drought, hypersalinity, and sewage spills have significantly altered the estuary.
When Tijuana Estuary was part of a large wetland resource base (i.e., through the early 1900 's), it was probably a resilient system. Occasional flooding would have eliminated marine invertebrates and fishes, but the effects would have been temporary, with larvae re-invading from San Diego Bay wetlands. Those wetlands have since dwindled to one-tenth their historic acreage. The populations (and genetic diversity) of many wetland-dependent species dwindled along with their habitat. The decline in both the quantity and quality of wetland habitats throughout the region has reduced the resiliency of Tijuana Estuary. Recovery of its historic biodiversity is unlikely without an active restoration program to reconstruct the tidal prism, return its marine character, expand habitat acreage, and expand species distributions.

\subsection{THE TIDAL RESTORATION PLAN}

The goals of restoration are to improve lidal flushing enough to maintain an open ocean inlet and to create and restore sufficient habitat for the maintenance of estuarine biodiversity. These goals are complementary: excavating sediments that have washed into the estuary will increase tidal flushing and expand wetland habitats. Most of the restoration work will be done in the southern arm of the estuary, where past sedimentation has been heaviest and where tidal flows are most sluggish.

\subsubsection{The Restoration Planning Process}

In 1984, the State Resources Agency and the State Coastal Conservancy provided funding to map the Research Reserve using $30-\mathrm{cm}$ (1 $1 \mathrm{ft}$.) contours and to develop a hydrologic model (Williams and Swanson 1987). This was followed by a 3-year resource assessment and impact evaluation process that was funded by the State Coastal Conservancy in 1988. 
Plans to restore full tidal flushing to the southern arm of Tijuana Estuary began with the hydrologic analysis. Williams and Swanson (1987) used the 1857 map as a model of what the estuary might need to become a fully tidal estuary. At this time, there was a 305-m-wide (1,000-foot) mouth and an estimated 1.8 million cubic meters (1,500 acre-ft) tidal prism (volume between MHHW and MLLW). About 352 ha $(870$ ac) of intertidal wetlands were estimated to be present. Tidal sloughs extended $914 \mathrm{~m}(3,000 \mathrm{ft})$ inland toward the east, $1,524 \mathrm{~m}(5,000 \mathrm{ft})$ north, and $610 \mathrm{~m}$ $(2,000 \mathrm{ft})$ south from the ocean inlet. A large area of open water was present in the southwesternmost part of the estuary.

Between 1852 and the present, there were many changes in geomorphology, hydrology, and hydrodynamics (Chapter 2, Figure 2.15). From the historic maps and aerial photos, it was estimated that $80 \%$ of the historic tidal prism had been eliminated during repeated sedimentation events. Sediments flowed in from the watershed and across the beach, depending on the type of storm event. With sea storms, the dunes were both flattened and pushed inland. Major beach retreal (90-120 $\mathrm{m}$; 300-400 ft) was documented for the 134-year period between 1852 and 1986.

Williams and Swanson (1987) summarized the major problems that would continue to plague the estuary if these physical processes were not controlled: 1) The esluary would continue to lose its tidal prism, through sedimentation down Tijuana River, down Goat Canyon, and across the beach during storm washovers. 2) Wetlands would continue to be converted to upland habitat. 3) Freshwater inflows could shift large areas of saline wetland to brackish wetland. 4), Wetland area would continue to decline as a consequence of accelerated sea level rise. 5) The encroachment of development in the river corridor would degrade the riparian habitat and increase flood hazards.

The hydrologisis then suggested an extensive dredging program (Figure 6.3) 10 be focused on the southern arm of the estuary. In the northern arm, a major new channel was proposed to connect the tidal ponds to the
Tijuana River channel--a measure that would maintain tidal access to Oneonta Slough after the migrating dune pinches off its current opening to Tijuana River and the ocean inlet.

Resource mapping and environmental impact assessment followed, with the preparation of an Environmental Impact Review and Environmental Impact Statement by Entrix, et al. (1991). A biological analysis was undertaken by PERL to determine what resources would be affected by the proposed dredging. Using recent air photos and extensive ground truthing, M. Busnardo and $\mathrm{J}$. Tiszler mapped the vegetation in detail. The fauna of the south arm were studied for the first time, with studies of terrestrial arthropods (Appendix $\mathrm{K} 3$ in Entrix et al. 1991, ), mammals (Appendix K5, ibid.), herpetofauna (Appendix K4, ibid.) and channel benthos (Appendix K2, ibid.). Bird use was evaluated in a comparative study of south and north arms (Appendix K1, ibid.; cf. Chapter 3).

From these field studies, PERL developed a "constraints map" (Figure 6.4) that detailed all areas considered sensitive, either for the lype of community present or the occurrence of rare and valued species. For example, the transition to upland that occurs south of the tidal ponds was considered too valuable to be dredged. Salt flats and high marsh habitat near Border Field overlook were shown to have high densities of Belding's Savannah sparrows and hence were considered 100 sensitive for conversion.

Modificalions to the 1987 plan were suggested to incorporate new information and ideas. A channel was proposed to be cut near the Visitor Center to improve tidal circulation while also enhancing opportunities for nature interpretation and reducing the need to bring visitors into endangered species habitats. The hydrologists were then asked to redesign the dredging program to avoid sensitive areas. Florsheim et al. (1991) redesigned the hydrology plan and responded to recommendations for an adaptive management approach, with two phases (a Model Project to precede full-scale restoration) and a modular approach (subunits that could be constructed as funding became available). 


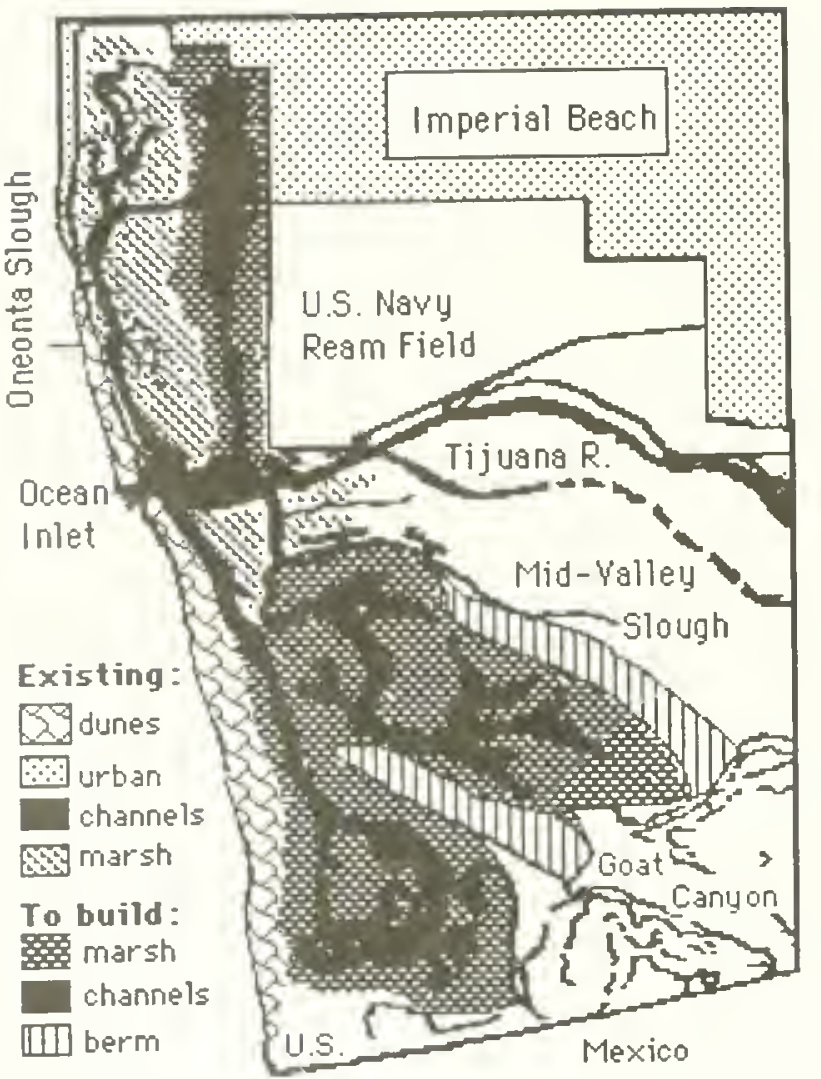

Figure 6.3. Initial design for hydrologic enhancement at Tijuana Estuary (from Williams and Swanson 1987). In this concept, a new tidal channel would provide flows to the inland lagoons and maintain flows to Oneonta Slough. In the southern arm, two tidal channel systems would be constructed (as two phases); each would be protected by a berm that would divert flood flows away from the excavation sites.

\subsubsection{The Model Project}

The Model Project has three features: First, an experimental marsh (Figure 6.5, at least 20 acres) would be constructed to determine how much detailed tidal creek excavation would be needed to accelerate ecosystem development (i.e., rapid increase in nutrient pools, plant growth, invertebrate populations, and bird use). The marsh would be subdivided into six areas, three with and three without tidal creek networks. The comparison of ecosystem development rates

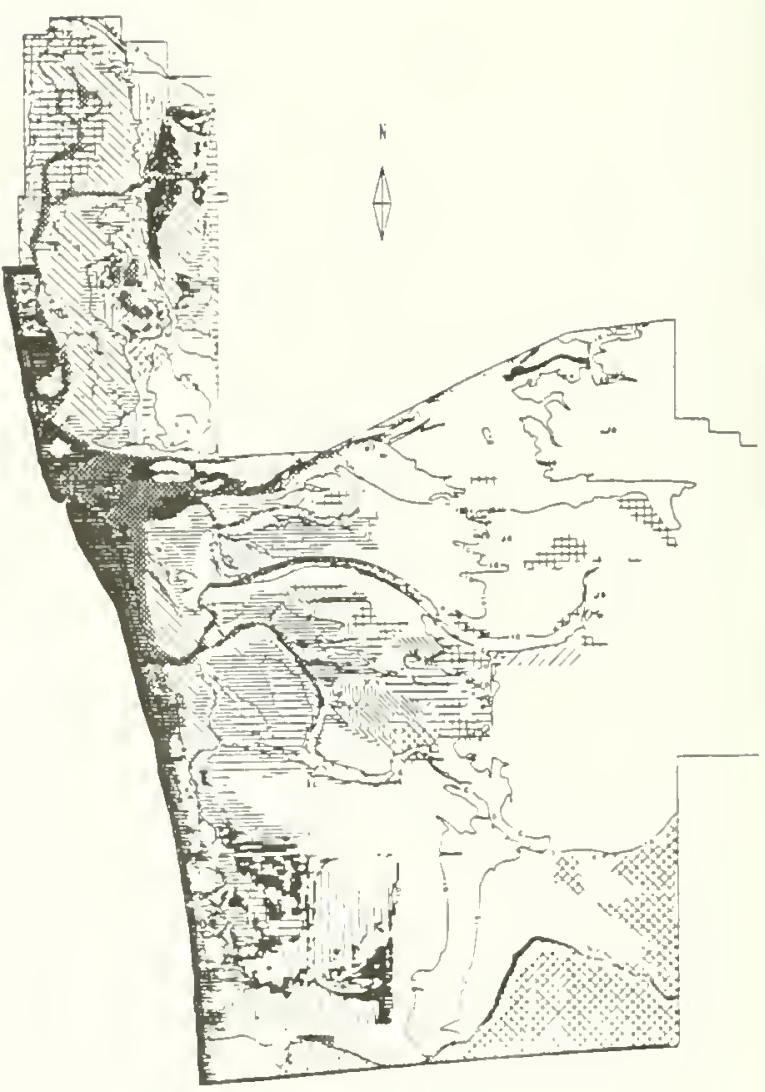

Figure 6.4. Constraints map showing sensitive areas at Tijuana Estuary. White areas were judged most suitable for restoration work. Symbols mark areas with critical and valued habitat for both plants and animals, e.g., occurrence of numerous endangered Belding's Savannah sparrows in the southwesternmost corner of the estuary. Mapping was done in 1988, using 1986 aerial photos.

under these two treatments would determine the need for tidal creek construction, which would add to the cost of marsh construction throughout the 495-acre restoration program.

The second feature is a new channel to connect the northern end of Oneonta Slough to the northern lidal pond. In addition to improving tidal flows, it will enhance nature interpretation and increase habital acreage. The channel will be excavated along the loe of the fill on which the Visitor Center is located 
and provide ready access for interpretive activities. Several of the estuary's habitats will be created within the excavation, including tidal creek, mudflat, lower-toupper marsh, and transition to upland. It is likely that the public will join in the habitat creation projects, much as volunteers have participated in planting and weeding the coastal scrub vegetation that landscapes the Visitor Center site.

The third feature is the widening of Oneonta Slough where a buried hard pan prevents inland migration of the channel. Unless the hard substrates are removed, tidal flows would eventually be pinched off as the dune gradually encroaches from the west. Maintaining Oneonta Slough as the tidal access for the north arm of the estuary will make it unnecessary to cut a new channel south of the tidal ponds, thus preserving the transitional wetland-upland habitats that occur there.

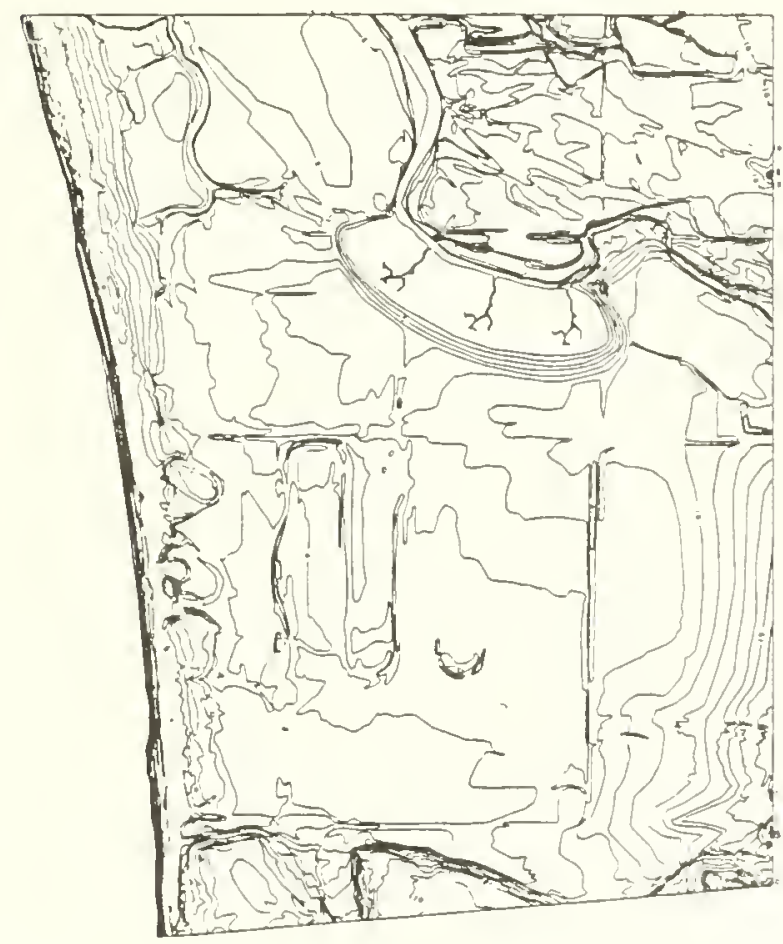

Figure 6.5. The 20-acre experimental marsh is the largest component of the first phase of the Tidal Restoration Plan. The importance of tidal creek networks will be tested by comparing ecosystem development in areas with and without such topographic heterogeneity.

\subsubsection{The 495-Acre Project}

It is expected that the 495-acre excavation (Figure 6.6) will be implemented over two or more decades, since the project will be costly and funds are nol currently available for the work. An innovative, modular approach will accomplish two adaptive management objectives. First, it will be possible to malch each funding opportunity with the restoration of one or more habitat modules. Rather than proceeding in a piecemeal fashion, the restoration will be completed in modules to make up the 495 acre program. Second, monitoring and research on each completed module will improve the next. As problems are identified, corrective measures can be built into later construction plans. As restoration methods are improved or new ideas developed, they can be incorporated into subsequent modules. The essence of adaptive management is a dynamic plan that can improve as knowledge accumulates and restoration science progresses.

\subsubsection{Restoration Research Needs}

Several questions remain about how to conduct the sediment removal program: How should the negative impacts of dredging be mitigated? Where should dredge spoils be deposited? How can river floods be diverted away from the restoration area to prevent further sediment deposition? How can the dunes be stabilized to prevent sedimentation of adjacent channels? How can we salvage vegetation that will be damaged during excavation? How should new marsh habitats be created to speed their development toward a fully functional wetland? How can the movements of undocumented aliens be diverted away from restored and other critical habitats?

In response to these needs the restoration plan (Entrix et al. 1991) details experimental projects, points out alternative restoration measures, and calls for supplemental impact analysis once choices are made. Four of the unresolved issues are discussed below: 


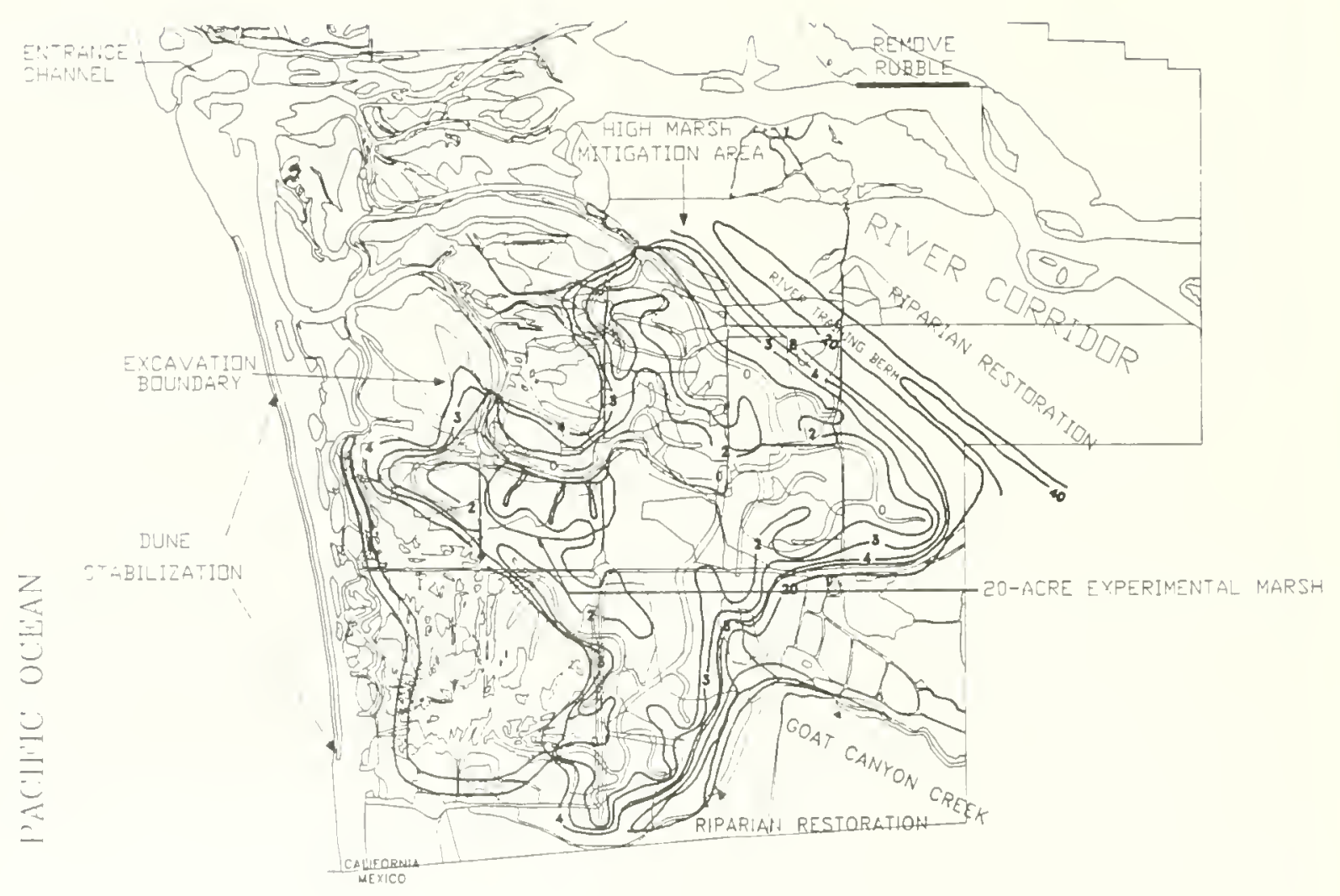

Figure 6.6. The 495-acre restoration plan to return tidal flows to the southern arm of Tijuana Estuary. Excavation to create channels and marsh would avoid ecologically sensitive areas (Figure 6.4). A single river-training levee (or berm) would divert sediments from future floods.

- River training levee or berm. The original plan (Figure 6.3, Williams and Swanson 1987) called for two large river training berms, the larger being $2.4 \mathrm{~km}$ (1.5 mi) long and $18 \mathrm{~m} \mathrm{(60} \mathrm{ft)} \mathrm{high;} \mathrm{these} \mathrm{berms}$ would consume most of the spoils dredged from the restoration site. Subsequent plans (Florsheim et al. 1991) eliminated the smaller berm and reduced the height of the larger berm to about $8 \mathrm{~m}(25 \mathrm{ft})$. It would be about $1.5 \mathrm{~km}(\sim 1 \mathrm{mi})$ long and cover 19 ha (46 ac). This size was estimated as the minimum necessary to protect the estuary through a 100-year flood event.

The berm was designed to be vegetated, but expected to erode with the larger floods. A wide berm would have sufficient sediment to accommodate erosion under most flood conditions. The berm has been an ecological concern, because it is not certain if the spoils will support native vegetation. It would also abut native bluffs that support coastal sage scrub and associated rare birds.

As an alternative, a levee was designed that would be lower $(3 \mathrm{~m}, 10 \mathrm{ft})$ and narrower $(30 \mathrm{~m}, 100 \mathrm{ft})$ and cover much less ground (5 ha, 12 ac; Entrix et al. 1991). The choice between a levee and a berm awaits further environmental review and results of research to be conducted on an experimental berm.

- Dredge spoil disposal. Dredging at Tijuana Estuary will generate spoils that differ in quality, depending on their source and presence of contaminants (to be assessed in a detailed sampling program). Sandy spoils may be used to replenish the beach and dunes, but spoils of low quality will be taken off site. Whether they are suitable for disposal on land will depend on their quality. High salinity 
and/or presence of contaminants will dictate their ultimate disposal. Off-shore deposition in an authorized deep-sea dump site is an additional option.

- Experimental berm. The feasibility of using dredge spoils for upland habitat creation will be determined in a major field experiment. A small berm will be constructed from the spoils from the Model Project. Experiments to vegetate the berm will test different plant species and different soil amendments. A primary concern is how rapidly the salty substrate will leach so that non-halophytic species can establish and grow. Should leaching prove to be rapid, the spoils could then be used for slope restoration at a nearby abandoned gravel pit and for capping and vegetating the proposed river training structure.

- Salvage efforts. Dredging to restore channels will disrupt small areas of benthic animal communities and creek-side vegetation and infauna. Tiger beelles have not been transplanted previously, but a relocation program will be attempted on an experimental basis before critical habitat is allowed to be damaged. To the extent possible, areas of native vegetation will be avoided; where unavoidable, a salvage and revegetation program will be undertaken. Experiments will focus on the size and depth of soil cores needed to retain native vegetation and soils, including root zones and seed banks. Other studies will compare species establishment rates with and without revegetation. The new channel adjacent to the Visitor Center will house these experiments and allow public interpretation, thus making Tijuana Estuary a major demonstration site for state-of-theart restoration methods.

\subsection{MITIGATION CONCERNS}

Throughout California, continuing development projects in coastal wetland habilats (e.g., highway widening, dock and marina construction, port expansion) have led to several mitigation projects. Their success or failure is rarely assessed, and quantitative documentation is rarely achieved (although see Langis et al. 1991, Zedler and Langis 1991, and Zedler 1991). Few mitigation projects increase habitat area; most simply change one type of wetland habitat into another. Yet changes in habitat quality do not compensate for reduced wetland area. More likely, they cause a loss in welland functioning. Nor does the exchange of quality for quantify fulfill President Bush's "no net loss" policy, which not only calls for acreage and function to be sustained, but also proposes a net gain in wetlands through the restoration process (Conservation Foundation 1988).

\subsubsection{Projects at Tijuana Estuary}

Small habitat restoration projects have been undertaken at Tijuana Estuary, and each has failed in one or more respects. Two were mitigation projects that were to offset habitat losses in San Diego Bay. In 1983, two dikes across the tidal lagoons were breached to improve tidal flushing. A segment of one dike was made into an island, with sand placed on top to create least tern nesting habitat. The proposed enhancement was supposed to mitigate a non-permitted fill operation in San Diego Bay. The project was poorly designed and had to be modified by the Fish and Wildlife Service prior to implementation. Unfortunately, specific goals were not enumerated, and the success of the "enhancement" was not assessed. After dike breaching, the northernmost tidal lagoon did show increased tidal flushing, but canine and human intruders were not deterred by the narrow breaches. And, rather than attracting terns, the sand added to the dike island stimulated weed invasions.

The second miligation project further widened one of the dike breaches to reduce human access. In addition, a deep "loop channel" was constructed around a patch of upper salt marsh. This project eliminated about 0.2 acres of urban fill (disturbed salt flat). It also made possible the eventual construction of the PERL tidal mesocosms, which now connect to the subtidal loop. No assessment or monitoring of the mitigation project was required or conducted. 
In a restoration project, the State Coastal Conservancy provided funds to replace about 10 acres of weedy vegetation with native plants in the disturbed upland area that is now the Visitor Center site. Burning was attempted without success; disking was then used to remove the weeds (mostly Chrysanthemum spp.). Native plant seeds were sown, but the weedy species reinvaded rapidly, and only a few native plants became established.

Plans to build a Visitor Center on the site included regrading and landscaping. with native vegetation. This final effort was directed by NERR Manager Paul Jorgensen and implemented with irrigation, repeated transplantation efforts, dozens of volunteers, including school children, donated plants, and continual weeding. The effort has been substantial, but it has produced a diverse native plant garden over much of the site. It is clear that planting is a small part of what is needed to reestablish native vegetation. Drought and exotic species pose major limits for success, and continual attention is needed to maintain the desired species and exclude the weeds.

\subsubsection{Projects at San Diego Bay}

Two large mitigation projects are underway at Sweetwater Marsh National Wildlife Refuge along the eastern shore of San Diego Bay. Both include the goal of creating nesting habitat for the light-footed clapper rail. One is a 12-acre site with 8 marsh islands constructed in 1984 and planted with cordgrass in 1985. The second is a 17-acre site excavated from dredge spoils in 1990 and planted with cordgrass in 1991. A research program funded by the California Sea Grant College and Caltrans has evaluated ecosystem development and initiated experiments to improve plant growth. The shortcomings of the sites have been documented. They include:

- Poor cordgrass growth due to insufficient soil nitrogen and soil organic matter (Langis et al. 1991, Cantilli 1989, Langis and Zedler 1991).
- Lower nitrogen fixation rates at the marsh soil surface (which indicates low organic matter/energy supplies for $\mathrm{N}$ fixers) and elevated nitrogen fixation rates in the rhizosphere (which indicates low concentrations of inorganic nitrogen in the soil), as documented by Zalejko (1989).

- Short cordgrass slature and unsuitability for clapper rail nesting (Zedler, in review).

- Herbivore outbreaks and decimation of transplanted cordgrass, presumably due to the absence of the natural predators (PERL, unpubl. data).

- Low abundance of epibenthic invertebrates, which indicates impaired foodchain support functions (Rutherford 1989).

- Invasion of newly constructed habitats by exotic species, e.g., Japanese mussels (potentially a dominant in the subtidal benthos; Rutherford 1989), yellowfin goby (a carnivore of unknown impact in welland channels; PERL, unpubl. data), and weedy plant species (especially near freshwater inflows; PERL, unpubl. data).

\subsubsection{Why Habitat Restoration is Difficult}

There are many reasons why restoration projects are hard to plan and why success is difficult to achieve. Arnong them are the following:

- We are trying to construct in a short time a system that developed in the absence of man over about 5,000 years.

- We don't know how the current wetlands developed--there are no blueprints to indicate how the topography developed, what species arrived first, what processes occurred to shape existing communities, what rare and extreme events influenced the occurrence and abundance of species.

- We don't know the dependencies among the components of the wetland--how species tolerate or depend on specific environmental 
conditions, how one species uses another as cover or food or habitat for reproduction.

- We can't predict how the dynamics of various populations will change in new surroundings; we don't have enough longterm data to know how variable populations can be and still persist in perpetuity. It is unrealistic to expect stability once a habitat is constructed.

- We don't know what factors confer resilience to species and communities. Pickleweed is a good invader after some disturbances and persists well under a variety of other disturbances. Tolerance to a wide range of salinities and inundation regimes appears to be important to pickleweed's resilience, but we have minimal understanding of why other species are less resilient.

- There have been few studies of constructed wetlands to allow us to predict the kinds of problems that will arise during construction.
None of these problems or shortcomings should halt efforts to restore ecosystems. Rather, the past experiences should be used to guide future restoration programs. Unexpected problems will occur, and a mechanism for dealing with those problems must be in place. Every site can be used to improve our ability to restore wetlands. Monitoring has a very important role in the implementation of restoration projects, but it should be linked to research programs and not just be a number-gathering process.

Most importantly, the problems must be acknowledged; in other words, just because a restoration design has been developed does not mean that the project will achieve it. Just because channels are excavated to the proper elevations does not mean they won't fill in or erode. Just because a transplanting program provides the desired species does not mean the vegetation will persist or that it will attract the desired animals.

The adaptive management program for Tijuana Estuary is the proper approach, and it should become the standard for all future restoration programs in the region. 


\section{REFERENCES}

Allen, L.G. 1980. Struclure and productivity of the littoral fish assemblage of upper Newport Bay, California. Ph.D. Dissertation, University of Southern California, Los Angeles. $175 \mathrm{pp}$.

American Ornithologists Union. 1983. A.O.U. checklist of North American birds, sixth edition. Allen Press, Inc. Lawrence, Kansas. 877 pp.

Atwood, J.L., and D. Minsky. 1983. Least tern foraging ecology at three major California breeding colonies. Western Birds 14:57-72.

Barbour, M.G., and J. Major, eds. 1977. Terrestrial vegetation of California. John Wiley and Sons, New York. 1002 pp.

Beare, P.A. 1984. Salinity tolerance in cattails (Typha domingensis Pers.): explanations for invasion and persistence in a coastal salt marsh. M.S. Thesis, San Diego State University, San Diego. 57 pp.

Beare, P.A., and J.B. Zedler. 1987 Cattail invasion and persistence in a coastal salt marsh: the role of salinity. Estuaries 10:165-170.

Bloom, A.L. 1983a. Sea level and coastal morphology of the United States through the Late Wisconsin glacial maximum. Pages 215-229 in S.C. Porter, ed. The Late Pleistocene, Vol. I. of H.E. Wright, Jr., ed. LateQuaternary environments of the United States. University of Minnesola Press, Minneapolis.
Bloom, A.L. 1983b. Sea level and coastal changes. Pages 42-51 in H.E. Wright, Jr., ed. The Holocene, Vol II. of H.E. Wright, Jr., ed. LateQuaternary environments of the United States. University of Minnesota Press, Minneapolis.

Boland, J.M. 1981. Seasonal abundances, habitat utilization, feeding strategies and interspecific compelition within a wintering shorebird community and their possible relationships with the latitudinal distribution of shorebird species. M.S. Thesis, San Diego State University, San Diego. 78 pp.

Boland, J.M. 1988. The ecology of North American shorebirds: Latitudinal distributions, community structure, foraging behaviors, and interspecific competition. Ph.D. Dissertation, University of California, Los Angeles. $256 \mathrm{pp}$.

Bradshaw, J.S. 1968. The biological and ecological relationships in the Peñasquitos Lagoon and salt marsh area of the Torrey Pines State Reserve Park. Calif. Div. Beaches Parks. Contract No. 4-05094-033.

Brothers, E.G. 1975. The comparative ecology and behavior of three sympatric California gobies. Ph.D. Dissertation, University of California, San Diego. 370 pp.

Busnardo, M.J., Jr. 1992. Removal of nitrogen and phosphorus by wetland mesocosms subjected to different hydroperiods. M.S. Thesis, San Diego State University. $38 \mathrm{pp}$. 
Bybee, J.R. 1969. Effects of hydraulic pumping operations on the fauna of the Tijuana Slough. Calif. Dept. Fish Game 55:213-220.

Cantilli, J.F. 1989. Sulfide phytotoxicity in tidal salt marshes. M.S. Thesis, San Diego State University. $115 \mathrm{pp}$.

Carpelan, L.H. 1969. Physical characteristics of southern California coastal lagoons. Pages 319-344 in A.A. Castañares and F.B. Phleger, eds. Lagunas Costeras, Un Simposio. Universidad Nacional Autonoma de Mexico, Ciudad Universitaria.

Cayan, D.R., and R.E. Flick. 1985. Extreme sea levels in San Diego, California. University of California, SIO Ref. No. 85-3.

Chalmers, A. 1982. Soil dynamics and the productivity of Spartina alterniflora. Pages 231-246 in V. C. Kennedy, ed. Estuarine comparisons. Academic Press, New York.

Conservation Foundation, The. 1988. Protecting America's wetlands: An action agenda. The final report of the National Wetlands Policy Forum. The Conservation Foundation, Washington D.C.

Covin, J.D. 1984. The role of inorganic nitrogen in the growth and distribution of Spartina foliosa at Tijuana Estuary, California. M.S. Thesis, San Diego State University. $60 \mathrm{pp}$.

Covin, J.D. 1986. Interactions between cordgrass and insects, varying soil nutrients and salinity. Report to the NOAA Office of Coastal Resource Management, Estuarine Sancluaries Div., Washington, D.C. 10 pp.

Covin, J.D., and J.B. Zedler. 1988. Nitrogen effects on Spartina foliosa and Salicornia virginica in the salt marsh at Tijuana Estuary, California. Wetlands 8:51-65.

Cowardin, L.M., V. Carter, F.C. Golet, and E.T. LaRoe. 1979. Classification of wetlands and deepwater habitats of the United States. Office of Biological Services, Fish and Wildlife Service, U.S. Dept. of the Interior, Washington, D.C. FWS/OBS-79/31. 103 pp.

Cox, G.W., and J.B. Zedler. 1986. The influence of mima mounds on vegetation patterns in the Tijuana Estuary salt marsh, San Diego County, California. Bull. South. Calif. Acad. Sci. 85(3): 158-172.

Crippen, R. W., and D. J. Reish. 1969. An ecological study of the polychaetous annelids associated with fouling material in Los Angeles Harbor with special reference to pollution. Bull. So. Calif. Acad. Sci. 68:170-187.

Davis, R.A., ed. 1978. Coastal sedimentary environments. SpringerVerlag, New York. 420 pp.

Dobbin Associates, J. 1986. Tijuana River National Estuarine Sanctuary Management Plan. Tijuana River National Estuarine Sanctuary Management Authority, San Diego. 109 pp.

Entrix, Inc., PERL, and PWA, Ltd. 1991. Tijuana Estuary Tidal Restoration Program. Draft Environmental Impact Report/Environmental Impact Statement. Calif. Coastal Conservancy (SCC) and U.S. Fish and Wildlife Service, Lead Agencies. SCC, Oakland. Vol. I-III.

Faber, P.M., E. Keller, A. Sands, and B.M. Massey. The ecology of riparian habitats of the southern California coastal region: a community profile. U.S. Fish Wildl. Serv. Biol. Rep. 85(7.27). $152 \mathrm{pp}$.

Fink, B. 1987. Stress tolerance of three coastal dune perennials. M.S. 
Thesis. San Diego State University. $64 \mathrm{pp}$.

Fink, B. 1989. Effects of dune overwash during the January 18 , 1988 storm at the Tijuana Estuary, San Diego, California. Shore and Beach $57: 41-43$.

Fink, B.H., and J.B. Zedler. 1989. Endangered plant recovery: Experimental approaches with Cordylanthus maritimus ssp. maritimus. Pp. 460-468 in H. G. Hughes and T. M. Bonnicksen, eds. Proceedings, First Annual Meeting of the Society of Ecological Restoration and Management. Madison, Wisconsin.

Flick, R.E., and D.R. Cayan. 1984. Extreme sea levels on the coast of California. Pages 886-898 in the 19th Coastal Engineering Conference Proceedings. American Society of Civil Engineers, New York.

Florsheim, J., P.B. Williams, L. Fishbain, and P Goodwin. 1991. Hydro-logic and geomorphic analysis of the Tijuana Estuary: Technical Appendix $E$ in Vol. II of Entrix, Inc., PERL, and PWA, Lid. 1991. Tijuana Estuary Tidal Restoration Program. Draft Environmental Impact Report/ Environmental Impact Statement. Calif. State Coastal Conservancy and U.S. Fish and Wildlife Service, Lead Agencies. Oakland, Calif.

Fong, P. 1986. Monitoring and manipulation of phytoplankton dynamics in a southern California estuary. M.S. Thesis, San Diego State University, San Diego. 80 pp.

Fong, P. 1991. Factors controlling algal abundance in shallow coastal lagoons: A combined modeling and experimental approach. Ph.D. Dissertation, University of California, Davis, and San Diego State University. $163 \mathrm{pp}$.
Ford, R.F., G. McGowen, and M.V. Needham. 1971. Biological inventory: investigations of fish, invertebrates and marine grasses in the Tijuana River Estuary. Pages 39-64 in Environmental impact study for the proposed Tijuana River flood control channel. Technical report to Ocean Studies and Engineering, Long Beach, Calif.

Foster, W.A., and J.E. Treherne. 1976. Insects of marine salt marshes: problems and adaptations. Pages 5-42 in L. Cheng, ed. Marine insects. American Elsevier Pub. Co., New York.

Franzreb, K. 1989. Ecology and conservation of the endangered least Bell's vireo. U.S. Fish Wildl. Serv., Biol. Rep. 89(1). 17 pp.

Fritz, E.S. 1975. The life history of the California killifish, Fundulus parvipinnis Girard, in Anaheim Bay, California. Pages 91-106 in The marine resources of Anaheim Bay. Calif. Dept. Fish Game, Fish Bulletin 165.

Grassle, J.F. and J.P. Grassle. 1976. Sibling species in the marine pollution indicator Capitella (Polychaeta) Science 192: 567-569.

Griner, E.L., and P. Pryde. 1976. Climate, soils, and vegetation. Pages 29-46 in P. Pryde, ed., San Diego: an introduction to the region. Kendall/Hunt, Dubuque.

Griswold, T. 1985. Intertidal benthos of the Tijuana Estuary: a qualitative survey following the 1984 closure to tidal flushing. Class report, Biology Department, San Diego State University, San Diego. 18 pp.

Griswold, T. 1988. Physical factors and competitive interactions affecting salt marsh vegetation. M.S. Thesis, San Diego State University. 84 pp. 
Griswold, T., and J. Zedler. 1990. Long-lerm dynamics of salt marsh vegetation at Tijuana Estuary. NOAA Tech. Mem. National Ocean Service, Office of Ocean and Coastal Resource Management, Marine and Estuarine Management Division. 21 pp.

Groenendijk, A.M. 1984. Tidal management: consequences for the salt-marsh vegetation. Water Sci. Technol. 16:79-86.

Grubb, P.J. 1977. The maintenance of species richness in plant communities: the importance of regeneration niche. Biol. Rev. 52:107-145.

Haines, E.B. 1979. Nitrogen pools in Georgia coastal waters. Estuaries $2: 33-39$.

Homziak, J. 1977. Substrate relationships and competition among three species of Callianassid shrimp. M.A. Thesis, San Diego State University, San Diego. 160 pp.

Hosmer, S.C. 1977. Pelecypodsediment relationships at Tijuana Estuary. M.A. Thesis, San Diego State University, San Diego. 119 pp.

Howarth, R.W., and J.C. Cole. 1985. Molybdenum availability, nitrogen limitation, and phytoplankton growth in natural waters. Science 229:653655.

Ibarra-Obando, S.E. and M. PoumianTapia. 1991. The effect of tidal exclusion on salt marsh vegetation in Baja California, Mexico. Wetlands Ecology and Management 1: 131-148.

Inman, D.L. 1985. Damming of rivers in California leads to beach erosion. Pages 22-26 in Oceans '85: Ocean engineering and the environment. Marine Technology Society and IEEE, vol. 1.

International Boundary and Water Commission (IBWC). 1950-1983.
Separate annual volumes: the flow of the Colorado River and other western boundary streams and related data.

International Boundary and Water Commission (IBWC). 1976b. Final Environmental Impact Statement, Tijuana River flood control project, San Diego County, California. 74 pp.

Johnson, K.M. 1991. The effects of host quality on a phytophagous insect (Homoptera: Delphacidae) and its predators in a California salt marsh system. M.S. Thesis, San Diego State University, San Diego. 82 pp.

Jorgensen, P.D. $1975 . \quad$ Habitat preferences of the light-footed clapper rail in Tijuana Estuary Marsh, California. M.S. Thesis, San Diego State University, San Diego. 115 pp.

Kern, J.P. 1977. Origin and history of upper Pleistocene marine terraces, San Diego, California. Geol. Soc. Am. Bull. 88:1553-66.

Ku, T.L., and J.P. Kern. 1974. Uranium-series age of the upper Pleistocene Nestor Terrace, San Diego, California. Geol. Soc. Am. Bull. 85:1713-1716.

Kus, B.E. and P.M. Ashfield. 1989. Bird use of the Tijuana River Estuary. Unpublished report, San Diego State University.

Kus, B.E. 1990a. Status of the Belding's Savannah sparrow (Ammodramus sandwichensis beldingi) at the Tijuana Estuary, 1990. Prepared for the Department of the Army, Corps of Engineers, Los Angeles District. 4 pp.

Kus, B.E. 1990b. Status of the least Bell's vireo at the Tijuana River, San Diego County, 1990. Prepared for the Department of the Army, Corps of Engineers, Los Angeles District. 7 pp.

Kus, B.E. 1991. Habilat use and breeding status of the least Bell's 
vireo at the Tijuana River, California, 1991. Prepared for the International Boundary and Water Commission. 11 pp.

LaJoie, K.R., J.P. Kern, J.F. Wehmiller, G.L. Kennedy, S.A. Mathieson, A.M. Sarna-Wojcicki, R.F. Yerkes, and P.F. McCrory. 1979. Quaternary marine shorelines and crustal deformation, San Diego to Santa Barbara, California. Pages $1-15$ in P.L. Abbott, ed. Geological excursions in the southern California area. Department of Geological Sciences. San Diego State University, San Diego.

Langis, R., M. Zalejko, and J.B. Zedler. 1991. Nitrogen assessments in a constructed and a natural salt marsh of San Diego Bay, California. Ecological Applications 1:40-51.

Larsen, E.B. 1953. Studies on the soil fauna of Skallingen. Oikos 3:1-29.

Lincoln, P. 1985. Pollinator effectiveness and ecology of seed set in Cordylanthus maritimus supsp. maritimus at Point Mugu, California. Final report to the US FWS, Endangered Species Office, Sacramento, Calif. Order \#10181-9750. 31 pp.

Macdonald, K.B., and M.G. Barbour. 1974. Beach and salt marsh vegetation of the north American Pacific coast. Pages 175-234 in R.J. Reimold, and W.H. Queen, eds. Ecology of halophytes. Academic Press, New York.

MacDonald, C.K. 1975. Notes on the family Gobiidae from Anaheim Bay. Pages 117-122 in E.D. Lane, and C.W. Hill, eds. The marine resources of Anaheim Bay. Calif. Dept. Fish Game, Fish Bull. 165.

Massey, B.W. 1974. Breeding biology of the California least tern. Proc. Limnol. Soc. N.Y. 72:1-29.
Massey, B.W. 1979. Belding's Savannah sparrow. Southern California Ocean Studies Consortium, California State University, U.S. Army Corps of Engineers, Los Angeles District. Contract No. DACW09-78C. 0008 .

Massey, B.W., and R.L. Zembal. 1979. A comparative study of the light-footed clapper rail Rallus longirostris levipes in Anaheim Bay and upper Newport Bay, Orange County, California. Preliminary report to U.S. Fish and Wildlife Service Endangered Species Office, Sacramento.

Massey, B.W., R. Zembal, and P.D. Jorgensen. 1984. Nesting habitat of the Light-footed Clapper Rail in southern California. J. Field Ornithol. 53:67-80.

Massey, B.W., and J.L. Atwood. 1984. Analysis of banded California least terns nesting on North Beach, Camp Pendleton. University of Calif., LoS Angeles.

Mayer, J.A. 1987. Soil morphology of the Tijuana River National Estuarine Sanctuary: northwest portion. M.S. Thesis, San Diego State University. $85 \mathrm{pp}$.

Mcllwee, W.R. 1970. San Diego County coastal wetlands inventory: Tijuana Slough. Unpublished report to Calif., Dept. Fish Game, Game Habitat Development.

McIntire, D. 1985. Insects of Tijuana Estuary. Unpublished report to Pacific Estuarine Research Laboratory, San Diego State University, San Diego.

Mclntire, G.L., and W.M. Dunstan. 1976. The seasonal cycle of growth and production in three salt marshes adjacent to the Savannah River. Unpubl. manuscript.

MCNeil, S., and T.R.E. Southwood. 1978. The role of nitrogen in the 
development of insect/plant relationships. Pages 77.98 in J.B. Harborne, ed., Biochemical aspects of plant and animal coevolution. Academic Press, London.

Minnich, R.A. 1983. Fire mosaics in southern California and northern Baja California. Science 219:1287-1294.

Minsky, D. 1984. California least tern foraging survey of the Santa Margarita River and environs. Report to Ecological Services, U.S. Fish Wildl. Service, Laguna Niguel. 26 pp.

Minsky, D.E., K. Keane, and A. White. 1983. A study of the breeding biology of the California least tern at Camp Pendleton. Report to Natural Resources Office, Camp Pendleton, Calif.

Mudie, P.J., and R. Byrne. 1980. Pollen evidence for historic sedimentation rates in California coastal marshes. Estuarine Coastal Mar. Sci. 10:305-316.

Munz, P.A. 1974. A flora of southern California. University of California Press, Berkeley. 1086 pp.

Nagano, C.D. 1982. The population status of seven species of insects inhabiting Tijuana Estuary National Wildlife Refuge, San Diego County, California. Report to the Office of Endangered Species.

Neuenschwander, L.F. 1972. A phytosociological study of the iransition between salt marsh and lerrestrial vegetation of Bahia de San Quintin. M.A. Thesis, California State University, Los Angeles. $70 \mathrm{pp}$.

Niesen, T.M. 1969. Population structure, dynamics, breeding cycles and ecotypic variation in San Diego populations of the sand dollar Dendraster excentricus. M.A. Thesis, San Diego State University, San Diego. 241 pp.
Nixon, S. 1980. Between coastal marshes and coastal waters--a review of twenty years of speculation and research on the role of salt marshes in estuarine productivity and water chemistry. Pages 437-525 in $P$. Hamilton and K. Macdonald, eds. Estuarine and wetlands processes. Plenum Press, New York.

Nordby, C.S. 1982. The comparative ecology of ichthyoplankton within Tijuana Estuary and its adjacent nearshore waters. M.S. Thesis, San Diego State University, San Diego. $101 \mathrm{pp}$.

Nordby, C.S. 1984. The role of rove beetles (Family Staphylinidae, Genus Bledius) as soil aerators at Tijuana Estuary. Report to the California State Coastal Conservancy, San Diego State University, San Diego. 18 pp.

Nordby, C.S., and J. B. Zedler. 1991. Responses of fishes and benthos to hydrologic disturbances in Tijuana Estuary and Los Peñasquitos Lagoon, California. Estuaries 14:80-93.

Nordby, C.S., J.B. Zedler, P. Williams, and J. Boland. 1980. Coastal wetlands restoration and enhancement. Report to U.S. Dept. of the Navy, Wildlife and Natural Resource Office, San Diego. $17 \mathrm{pp}$.

Odum, E.P. 1971. Estuarine ecology. Pages 352-362 in E.P. Odum, Fundamentals of ecology. W.B. Saunders, Philadelphia.

Office of Coastal Zone Management and the California Coastal Commission. 1981. Tijuana River Estuarine Sanctuary: Final Environmental Impact Statement. U.S. Dept. of Commerce, Wash. D.C., and State of California, San Francisco. 203 pp.

Onuf, C.P. 1987 . The ecology of Mugu Lagoon: an estuarine profile. U.S. Fish Wildl. Serv. Biol. Rep. 85 (7.15). $122 \mathrm{pp}$. 
Onuf, C.P., and M.L. Quammen. 1983. Fishes in a California coastal lagoon: effects of major storms on distribution and abundance. Mar. Ecol. Prog. Ser. 12:1-14.

Onuf, C.P., J.M. Teal, and I. Valiela. 1977. Interactions of nutrients, plant growth and herbivory in a mangrove ecosystem. Ecology 58:514-526.

Onuf, C.P., M.L. Quammen, G.P. Shaffer, C.H. Peterson, J.W. Chapman, J. Chermak, and R.W. Holmes. 1978. An analysis of the values of central and southern California wetlands. Pages 189-199 in P.W. Greeson, J.R. Clark, and E.J. Clark, eds. Wetlands functions and values: The state of our understanding. American Water Resources Association, Minneapolis.

Page, G.W. and L. E. Stenzel. 1981. The breeding status of the snowy plover in California. Western Birds 12:1-40.

Page, G.W., L.E. Stenzel, J.E. Kjelmyr, and W.D. Shuford. 1990. Shorebird numbers in wetlands of the Pacific Flyway: A summary of Spring and Fall counts in 1988 and 1989. Contribution Number 471, Point Reyes Bird Observatory.

Page, G.W. L.E. Stenzel, and W.D. Shuford. 1991. Distribution and abundance of the snowy plover on its western North American breeding grounds. J. Field Ornithology. 62: 245-255.

Patton, R. 1991. Untitled report. Prepared for the Department of the Army, Corps of Engineers, Los Angeles District.

Peterson, C.H. 1975. Stability of species and of community for the benthos of two lagoons. Ecology 56:958-965.

Pomeroy, L.R., and R.G. Wiegert. 1981. The ecology of a salt marsh. SpringerVerlag, New York. 271 pp.
Powell, J.A. 1981. Endangered habitats for insects: California coastal sand dunes. Atala 6:41-55.

Pritchard, D.W. 1967. What is an estuary: physical viewpoint. Pages 3-5 in G.H. Lauff, ed. Estuaries. Am. Assoc. Adv. Sci., Washington, D.C.

Pryde, P.R. 1976. San Diego: an introduction to the region. Kendall/Hunt, Dubuque. $267 \mathrm{pp}$.

Purer, E.A. 1936a. Studies of certain coastal sand dune plants of southern California. Ecol. Monogr. 6:1-87.

Purer, E.A. 1936b. Plants of Silver Strand Beach State Park, San Diego County, California: a visitors' handbook. Science Press Printing Co., Lancaster, Penn. 98 pp.

Purer, E. 1942. Plant ecology of the coastal salt marshlands of San Diego County. Ecol. Monogr. 12:82-111.

Regional Environmental Consultants (RECON). 1989. Comprehensive species management plan for the least Bell's vireo. Prepared for the San Diego Association of Governments.

Rehse, M.A. 1981. Faunal recovery in Tijuana Estuary. Unpubl. report, San Diego State University, San Diego. 19 pp.

Resources Partnership. 1974. Marine resources training project. Environmental Committee, Commission of the Californias. University of California, Los Angeles. Map \#2.

Richards, L.A., ed. 1954. Diagnosis and improvement of saline and alkali soils. Agric. Handbook No. 60, U.S. Dept. Agric., Washington, D.C. 160 pp.

Rudnicki, R. 1986. Dynamics of macroalgae in Tijuana Esluary: response to simulated wastewater addition. M.S. Thesis, San Diego State University, San Diego. 55 pp. 
Rutherford, S.E. 1989. Detritus production and epibenthic communities of natural versus constructed salt marshes. M.S. Thesis, San Diego State University.

Scott, D. 1976. Quantitative studies of marsh Foraminiferal patterns in southern California and their application to Holocene stratigraphic problems. Pages 153.170 in 1st international symposium on benthonic Foraminifera of continental margins. Part A. Ecology and biology, maritime sediments. Spec. Pub. 1., Dalhousie University, Halifax, N.S.

Seamans, P. 1988. Wastewater creates a border problem. Journal of the Water Pollution Control Federation. $60: 1798-1804$.

Seneca, E.D., and U. Blum. 1984. Response to photoperiod and temperature by Spartina alterniflora (Poaceae) from North Carolina and Spartina foliosa from California. Am. J. Bot. 71:91-99.

Sharp, J.H. 1974. Improved analysis for "particulate" organic carbon and nitrogen from seawater. Limnol. Oceanogr. 19:984-989.

Sinicrope, T.L. 1992. Removal of metals by wetland mesocosms subjected to different hydroperiods. M.S. Thesis, San Diego State University.

Smalley, A.E. 1959. The growth cycle of Spartina and its relation to the insect populations in the marsh. Pages 96-100 in Proceedings of salt marsh conference. University of Georgia Marine Institute, Sapelo Island.

Smith, S.H. 1974. The growth and mortality of the littleneck clam, Protothaca staminea, in Tia Juana Slough, California. M.S. Thesis, San Diego State University, San Diego. $116 \mathrm{pp}$.
Smith, S.V. 1984. Phosphorus versus nitrogen limitation in the marine environment. Limnol. Oceanogr. 29:1149-1159.

Strickland, J.D.H., and T.R. Parsons. 1972. A practical handbook of seawater analysis. Fisheries Research Board of Canada, Ottawa. 310 pp.

Taylor, R.W. 1978. 1976-1977 solar radiation data for San Diego County. San Diego Gas and Electric Co., San Diego. $17 \mathrm{pp}$.

Turner, R.E. 1976. Geographic variations in salt marsh macrophyte production: a review. Contrib. Mar. Sci. 20:47-68.

United States Department of Agriculture (USDA). 1982. National list of scientific plant names, Volume 1 List of plant names. Soil Conservation Service Publication SCS-TP-159. Washington, D.C. 416 pp.

United States Geological Survey (USGS). 1937-1970. Separate annual vols: Water Supply Papers. 1971-1981: Water Resource Data for California, Water Years 1971-1980.

Unitt, P. 1984. Birds of San Diego County. San Diego Society of Natural History, Memoir 13.

Vanderweir, J.M. 1983. Mugu Lagoon. Pages 117-126 in Proceedings, San Nicholas Island Ecological Research Symposium. Pacific Missile Test Center, Point Mugu, California.

Vourlitis, G.L. 1991. The importance of nitrogen in a southern California coastal dune slack community. M.S. Thesis, San Diego State University, San Diego. 88 pp.

Waisel, Y. 1972. Biology of halophytes. Academic Press, New York. 395 pp.

Walters, C.J., and R. Hillborn. 1978. Ecological optimization and adaptive 
management. Ann. Rev. Ecol. Syst. $9: 157-188$.

Warnock, N., S. Griffin, and L.E. Stenzel. 1989. Results of the 22-23 April 1989 shorebird census in coastal wellands of San Diego County and northern Baja California. Contribution Number 408, Point Reyes Bird Observatory.

Webb, C. K., D. A. Stow, and K. S. Baron. 1989. Morphologic response of an inlet-barrier beach system to a major storm. Shore and Beach 57:37-40.

White, A.N. 1986 Wetland habitat use by the endangered Belding's Savannah sparrow (Passerculus sandwichensis beldingi). M.S. Thesis, San Diego State University, San Diego. 73 pp.

Williams, P. 1979. Detritus utilization by Mytilus edulis. M.S. Thesis, San Diego State University. 49 pp.

Williams, P. 1981. Detritus utilization by Mytilus edulis. Estuarine Coastal Shelf Sci. 12:739-746.

Williams, P.B. and M.L. Swanson. 1987. Tijuana Esluary enhancement hydrologic analysis. $50 \mathrm{pp}$.

Williams, W., and J. Williams. 1984. Ten years of vegetation change on the coastal strand at Morro Bay, California. Bull. Torrey Bot. Club III(2): $145-152$.

Winfield, T.P. 1980. Dynamics of carbon and nitrogen in a southern California salt marsh. Ph.D. Dissertation, University of California, Riverside, and San Diego State University, San Diego. 76 pp.

Wood, L.F., and J.B. Zedler. 1987. Dune interactions between the exotic annual, Cakile maritima, and the native perennial, Abronia maritima. Proc., Wetland and Riparian Ecosystems of the American West
(Eighth Ann. Meeting of the Soc. of Welland Scientists):322-323.

Zalejko, M.K. 1989. Nitrogen fixation in a natural and a constructed southern California salt marsh. M.S. Thesis, San Diego State University.

Zedler, J.B. 1975. Salt marsh community structure along an elevation gradient. Bull. Ecol. Soc. Am. $56: 47$.

Zedler, J.B. 1977. Salt marsh community structure in the Tijuana Estuary, California. Estuarine Coastal Mar. Sci. 5:39-53.

Zedler, J.B. 1980. Algal mat productivity: comparisons in a salt marsh. Estuaries 3:122-131.

Zedler, J.B. 1982a. Salt marsh algal composition: spatial and temporal comparisons. Bull. S. Calif. Acad. Sci. $81: 41-50$.

Zedler, J.B. 1982b. The ecology of southern California coastal salt marshes: a community profile. U.S. Fish Wildl. Serv., Biol. Serv. Program FWS/OBS-81/54. 110 pp.

Zedler, J.B. 1983a. Salt marsh restoration: the experimental approach. Proceedings, Coastal Zone '83, Vol. III:2578-2586. American Society of Civil Engineers, New York.

Zedler, J.B. 1983b. Freshwater impacts in normally hypersaline marshes. Estuaries 6:346-355.

Zedler, J.B. 1984. Salt marsh restoration: a guidebook for southern California. Calif. Sea Grant Coll. Program. Rep. No. 7-CSGCP-009. $46 \mathrm{pp}$.

Zedler, J.B. 1986. Catastrophic flooding and distributional patterns of Pacific cordgrass (Spartina foliosa Trin.). Bull. S. Calif. Acad. Sci. 85:74-86. 
Zedler, J.B. 1988. Salt marsh restoration: lessons from California. Pages 123-138 in J. Cairns, ed. Management for rehabilitation and enhancement of ecosystems. CRC Press, Boca Raton, Fla.

Zedler, J.B. 1991a. Catastrophic events and interannual variability at Tijuana Estuary. Pages 195-201 in P. L. Abbott and W. J. Elliolt, eds. Environmental Perils. San Diego Association of Geologists. San Diego.

Zedler, J.B. 1991b. The challenge of protecting endangered species habitat along the southern California coast. Coastal Management 19:35-53.

Zedler, J.B. In review. Canopy architecture of natural and planted cordgrass marshes: Selecting habitat evaluation criteria. Ecological Applications.

Zedler, J.B., and P.A. Beare. 1986. Temporal variability of salt marsh vegetation: the role of low-salinity gaps and environmental stress. Pp. 295-306 in D. Wolfe, ed. Estuarine variability. Academic Press, New York.

Zedler, J.B., J. Covin, C. Nordby, P. Williams, and J. Boland. 1986. Catastrophic events reveal the dynamic nature of salt marsh vegetation. Esluaries 9:75-80.

Zedler, J.B., and G.W. Cox. 1984. Characterizing wetland boundaries: a Pacific coast example. Wetlands $4: 43-55$.

Zedler, J.B., J.D. Covin, C.S. Nordby, P. Williams, and J. Boland. 1986. Catastrophic events reveal the dynamic nature of salt marsh vegetation. Estuaries 9:75-80.

Zedler, J.B., Koenigs, R., and W.P. Magdych. 1984a. Streamflow for the San Diego and Tijuana Rivers. San
Diego Association of Governments, San Diego. $52 \mathrm{pp}$.

Zedler, J.B., Koenigs, R., and W.P. Magdych. 1984b. Review of salinity and predictions of estuarine responses to lowered salinity. State of California Water Resources Control Board, San Diego Assoc. of Governments. 51 pp.

Zedler, J.B., and R. Langis. 1991. Comparisons of constructed and natural salt marshes of San Diego Bay. Restoration \& Management Notes $9: 21-25$

Zedler, J.B., R. Langis, B. Nyden and M. Busnardo. 1991. Assessing the effects of sewage inflows on Tijuana Estuary. Tech. Mem. National Ocean Service, Office of Ocean and Coastal Resource Management, Marine and Estuarine Management Division.

Zedler, J.B., W.P. Magdych, and the San Diego Association of Governments. 1984c. Freshwater release and southern California coastal wetlands. Management treatment plan for the beneficial use of treated wastewater in the Tijuana River and San Diego River Estuaries. San Diego Association of Governments, San Diego. 74 pp.

Zedler, J.B., and C.S. Nordby. 1986. The ecology of Tijuana Estuary: an estuarine profile. U.S. Fish Wildl. Serv. Biol. Rep. 85 (7.5). 102 p.

Zedler, J.B., and C.P. Onuf. 1984. Biological and physical filtering in arid-region estuaries: seasonality, extreme events, and effects of watershed modification. Pages 415. 432 in V.S. Kennedy, ed. The estuary as a filter. Academic Press, New York.

Zedler, J.B., T.P. Winfield, and P. Williams. 1980. Salt marsh productivity with natural and altered tidal circulation. Oecologia (Berl.) $44: 236-240$. 
Zembal, R. W. 1990. Light-footed clapper rail census and study, 1990. Final report to California Department of Fish and Game, December 1990. California State University, Long Beach. 28 p.

Zembal, R. W. 1991. Light-footed clapper rail census and study, 1991. Preliminary report to California Department of Fish and Game, July 1991. California State University, Long Beach. $8 p$.

Zembal, R., K.J. Kramer, R.J. Bransfield, and N. Gilbert. 1988. A survey of Belding's Savannah sparrows in California. American Birds 42:1233-1236.

Zembal, R.L., and B.W. Massey. $1981 \mathrm{a}$. Continuation study of the light-footed clapper rail Rallus longirostris levipes, 1981. Report to the California Department of Fish and Game, Sacramento.

Zembal, R.L., and B.W. Massey. 1981b. A census of the light-footed clapper rail in California. Western Birds 12:87-99. 


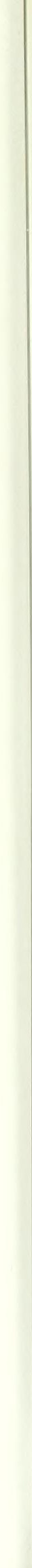



